\title{
LA ASAMBLEA \\ NACIONAL FRANCESA \\ DE 1789-1791 \\ Y LA INVENCIÓN \\ DE LA CONSTITUCIÓN
}

\section{DAVID PANTOJA MORÁN}


LA ASAMBLEA NAGIONAL FRANCESA DE 1789-1791 Y LA INVENGIÓN DE LA CONSTITUGIÓN 


\title{
INSTITUTO DE INVESTIGACIONES JURÍDICAS
}

Serie Estudios JuRídicos, núm. 303

\section{COORDINACIÓN EDITORIAL}

\author{
Lic. Raúl Márquez Romero \\ Secretario Técnico
}

Lic. Wendy Vanesa Rocha Cacho

Jefa del Departamento de Publicaciones

María Teresa de Jesús Baena Sánchez

Cuidado de la edición

Iván Ismael Escoto Mora

Apoyo editorial

José Antonio Bautista Sánchez

Formación en computadora

Edgar Daniel Martínez Sánchez

Elaboración de portada 


\section{DAVID PANTOJA MORÁN}

\section{LA ASAMBLEA \\ NAGIONAL FRANGESA \\ DE 1789-1791 \\ Y LA INVENCIÓN \\ DE LA CONSTITUCIÓN}
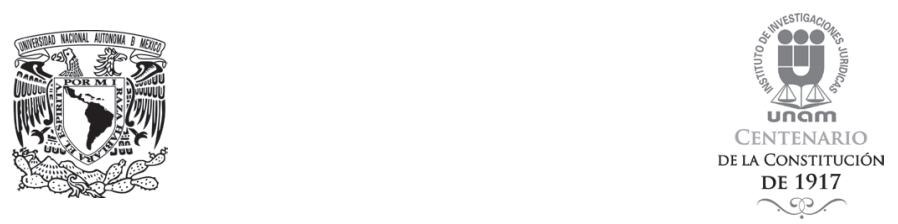

UNIVERSIDAD NACIONAL AUTÓNOMA DE MÉXICO INSTITUTO DE INVESTIGACIONES JURÍDICAS MÉXICO, 2017 
Primera edición: 7 de abril de 2017

DR C 2017. Universidad Nacional Autónoma de México

\section{INSTITUTO DE INVESTIGACIONES JURÍDICAS}

Circuito Maestro Mario de la Cueva s/n

Ciudad de la Investigación en Humanidades

Ciudad Universitaria, 04510 Ciudad de México

Impreso y hecho en México

ISBN 978-607-02-9057-2 


\section{CONTENIDO}

Presentación. ...................... 1

Introducción $\ldots \ldots \ldots \ldots \ldots \ldots \ldots \ldots \ldots \ldots \ldots$

I. La crisis del antiguo régimen $\ldots \ldots \ldots \ldots \ldots \ldots, 11$

II. Las leyes fundamentales del antiguo régimen y la nueva idea de Constitución . . . . . . . . . . . . . . 20

III. Las primeras experiencias en el debate constitucional . 26

IV. La Declaración de los Derechos del Hombre y del Ciudadano ......................... 53

V. La idea de soberanía. . . . . . . . . . . . . . . . . . 72

1. La distinción entre poder constituyente y poderes

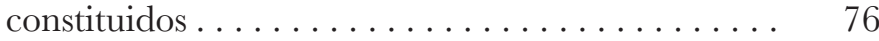

2. La idea de soberanía y el sistema representativo. La delegación del ejercicio de competencias . . . . . . 79

3. El sistema representativo y el poder comitente . . . 88

4 . Voluntad general, voluntad de todos y gobierno representativo................. 90

5. La idea de soberanía, forma de gobierno y naturaleza de la relación que une a electores y a elegidos . $\quad 91$

6. La idea de soberanía y la concepción del sufragio . 96

7. Crítica a la doctrina que opone a la idea de soberanía popular a la de soberanía nacional . . . . . . . 105

VI. Discusiones relativas a la ingeniería constitucional. . 106 
1. La ingeniería de la sanción real, el derecho de veto y el bicamarismo. . . . . . . . . . . . . 106

2. La ingeniería del Poder Legislativo . . . . . . . . 120

3. La ingeniería de la relación entre las Cámaras entre sí y la de éstas frente al rey . . . . . . . . . . . . . . . 124

VII. La lenta y tortuosa elaboración de la Constitución. . 138

VIII. La evolución de la concepción sobre la monarquía. . 142

IX. La separación de los poderes . . . . . . . . . . . 147

1. El artículo 16 de la Declaración de los Derechos del Hombre y del Ciudadano. . . . . . . . . . . . . . 147

2. Montesquieu y la separación de poderes. . . . . . . 151

3. El principio de la separación de los poderes y el diseño de las instituciones políticas . . . . . . . . . 158

Datos biográficos..................... 191

Bibliografía . . . . . . . . . . . . . . . . . . 197

Acerca del autor ................... 207 
Este libro forma parte del acervo de la Biblioteca Jurídica Virtual del Instituto de Investigaciones Jurídicas de la UNAM

\section{PRESENTACIÓN}

El presente trabajo fue concebido hace ya varios años como un ejercicio para mi propia comprensión de los instrumentos conceptuales usados en la gestación del constitucionalismo. En dicha época iniciaba la elaboración de una tesis de doctorado que versaba sobre temas de teoría e historia constitucional, y el referente obligado era el constitucionalismo francés. Tuve que acudir a las fuentes y fue así como me encontré con la Asamblea Constituyente de 1789 a 1791.

Esa reunión mítica, extraordinariamente larga de duración y rica en avatares, fue el caldero donde se mezclaron ideas que tenían muchos padres, proveyentes de numerosas épocas y latitudes y que habían pasado por diversos filtros: Bodin, Mably, Montesquieu, Rousseau, Loke, Jefferson Adams; en fin, la Ilustración, el constitucionalismo inglés y el constitucionalismo norteamericano. Los diputados constituyentes que acudieron a esa asamblea fueron los alquimistas que lograron las mixturas, tras una lucha enconada ideológica en la que se enfrentaron no sólo las concepciones teóricas, sino los intereses políticos y materiales.

En ese, sin precedente, magno seminario de "Teoría política", como algunos quieren verlo, se concibió o "se inventó" la primera Constitución de la historia francesa. Documento fundamental que tiene, entre otras virtudes, una gran aportación pedagógica, pues no es una mera ordenación de reglas o disposiciones, sino que se acompañaron a tales normas los valores y principios que las sustentaban y legitimaban.

Cierto es que le antecedían en el tiempo las constituciones inglesa y norteamericana, pero la primera no es escrita y esencialmente mutable, por la obra de los precedentes y las convenciones, y la norteamericana, en su laconismo, es meramente instrumen- 
Este libro forma parte del acervo de la Biblioteca Jurídica Virtual del Instituto de Investigaciones Jurídicas de la UNAM

tal y dejada a la suerte de su interpretación. En cambio, la Constitución francesa de 1791 contiene una verdadera teoría del Estado, como lo descubrieran autores de fuste y se sustenta en este trabajo, ya que hace manifiestos los valores y principios en que se apoya, es decir, hay una amplia y fundada teoría constitucional.

Para poder entender el sentido, los alcances, las conexiones de esas concepciones acudí a los debates de los principales temas tocados y a lo que expresaron algunos de los diputados más representativos de las posiciones confrontadas. Como no se trataba de un trabajo de gran aliento, para lo que no estaba ni estoy preparado, pues hubiera sido menester "bucear" en los archivos nacionales, sólo me serví de investigaciones excelentes que contenían extractos relevantes de los debates esenciales, porque se trataba de encontrar ciertas claves en la comprensión de los principios. En efecto, no se trataba de repetir excelentes trabajos ya realizados, sino sólo de utilizarlos, puesto que al fin de cuentas no era el propósito la búsqueda de nuevos hallazgos, sino el de ahondar en la comprensión de lo ya encontrado.

Con el concurso de las aportaciones de varias autoridades en la materia, me lancé a tratar de desentrañar el sentido profundo de los mecanismos que constituyen el gobierno moderno, a partir de la Revolución francesa, nunca con la inútil y fatua intención de elaborar algo nuevo o de superar teorías, sino algo mucho más modesto: intentar hacerme entender a mí mismo lo que los diputados de la Asamblea Nacional de 1789 a 1791 habían construido en esa reunión celebérrima. ¿Por qué una Constitución escrita? ¿Por qué hacerla preceder de una declaración de derechos? ¿Dónde ubicar el fundamento del poder? ¿Por qué la nación como sede o titular de la soberanía? ¿Cómo relacionar soberanía nacional y sistema representativo? ¿Por qué la necesidad de dividir a los poderes? ¿Cómo conciliar la unidad del poder con la separación de los poderes? En la perspectiva de la separación de los poderes, ¿podía el Ejecutivo participar en las funciones legislativas; el Legislativo en las gubernamentales o en las jurisdiccionales? ¿Cómo resolver la disyuntiva entre una o dos 
Este libro forma parte del acervo de la Biblioteca Jurídica Virtual del Instituto de Investigaciones Jurídicas de la UNAM

Cámaras? En suma, ¿a qué principios o valores respondía el diseño de las instituciones políticas o, como hoy se quiere, la ingeniería constitucional?

Como quiera que, desde el inicio de los trabajos de la asamblea, la discusión de los temas se mezcló con acontecimientos que en mayor o menor medida influyeron sobre las determinaciones, me pareció necesario mencionarlos, a fin de contextualizar los debates y, con ello, contribuir a su mejor comprensión.

Como antes se decía, inicialmente el trabajo fue concebido como un insumo para una tesis y pasó varios años en un cajón abandonado a la crítica roedora del tiempo. La necesidad de facilitar a mis alumnos la comprensión de teoría general del Estado y de derecho constitucional, me impulsaron a exhumarlo, rehacerlo y prepararlo para su edición. Es a ellos y a los que se inician en esos estudios a quienes está dirigido, con la esperanza de que sea de utilidad.

En la parte final del trabajo se encuentra una sección con datos biográficos de los diputados constituyentes más conspicuos, a fin de contextualizar mejor el sentido de sus intervenciones. También al final consta la bibliografía utilizada.

Por último, pero no al último, deseo dejar en estas líneas un testimonio de gratitud a mis profesores del primer año en la Facultad de Derecho de la UNAM, que en 1956 me mostraron la grandeza de esta benemérita Universidad: Benjamín Flores Berrueta, Guillermo Floris Margadant, Hugo Rangel Couto, Luis Recaséns Siches y Rafael Rojina Villegas.

Tlalpan, Ciudad de México, marzo de 2016 
Este libro forma parte del acervo de la Biblioteca Jurídica Virtual del Instituto de Investigaciones Jurídicas de la UNAM

\section{INTRODUCGIÓN}

El sentimiento que decidió el primer estallido de la Revolución, el que excitó sus más violentos esfuerzos y obtuvo sus éxitos más grandes, fue el amor a la igualdad: fue la impaciencia ante las desigualdades.

L'Esprit de la Révolution de 1789 Pierre-Louis ROEDERER

Junto a la Constitución inglesa y a la norteamericana de 1787, la Constitución francesa de 1791 representa un paradigma en el derecho constitucional comparado de obligada referencia. A lo largo de siglos, en lenta evolución y de manera consuetudinaria, se gestaron en Inglaterra instituciones y prácticas políticas que han servido de modelo para las del resto del mundo. Por otra parte, también debemos a la Constitución de Filadelfia de 1787 algunas construcciones política-jurídicas originales. Pero estamos en deuda con el genio francés por la conceptualización, la explicación y la racionalización de los principios que sustentan a dichas instituciones.

La Constitución de 1791 representa un modelo de importancia capital para las subsecuentes Constituciones francesas y para las de otros países, entre otros, las mexicanas. Aparece bajo dos aspectos y realiza por primera vez la síntesis de dos tendencias.

La primera es llamada, por Troper, "instrumental" o "mecánica", pues corresponde a la voluntad no sólo de organizar el poder, sino de organizarlo de tal forma que no pueda jamás ejer- 
Este libro forma parte del acervo de la Biblioteca Jurídica Virtual del Instituto de Investigaciones Jurídicas de la UNAM

cerse de manera despótica, aunque los gobernantes lo quisieran. La segunda es totalmente novedosa y constituye una revolución frente a la Constitución norteamericana. Es así que debemos a la Asamblea Constituyente de 1789 a 1791 no sólo el que haya legado las reglas para instituir órganos, determinar sus competencias, organizar sus relaciones recíprocas, establecer límites al poder de los gobernantes, reconocer y garantizar los derechos de los gobernados, etcétera. Además, que haya enunciado los principios que justifican esas reglas y precisado el origen de dónde parecen derivar. Esos principios son todavía los que pueden justificar las reglas del derecho público contemporáneo. Así, bajo esos dos aspectos Troper considera que no es exagerado decir que aún vivimos bajo los presupuestos de la Constitución de $1791 .^{1}$

Siguiendo a Carré de Malberg, en efecto, el derecho constitucional sería el material de donde la ciencia extraería los datos para concebir la Teoría del Estado. Esos datos o ideas fundamentales del derecho constitucional no serían las reglas, sino lo que no aparece directamente en el derecho positivo, es decir, los principios que fundan las reglas. Carré de Malberg - quien descubrió esos principios en la Constitución francesa de 1791 e influido por la escuela alemana del derecho público - emprendió la tarea de hacer representar a esa primera constitución de la historia francesa el papel que el derecho romano jugó para el derecho privado, o sea: fundar una ciencia del derecho público del Estado, de ahí su importancia. ${ }^{2}$

Dicha Constitución, además no sólo se limitó al establecimiento de normas jurídico-políticas abstractas, sino que al for-

1 Véanse Troper, Michel, "La constitution de 1791 aujourd'hui", Revue francaise de droit constitutionnel, núm. 9, 1992, pp. 3 y 4; Troper, Michel y Jaume Lucien, "Avant-propos. Une nouveauté toujours actuelle, le texte de 1791", en Troper, Michel y Jaume, Lucien (dirs.), 1789 et l'invention de la constitution, LGDJBruylant, 1994.

2 Carré de Malberg, R., Contribution á la théorie générale de l'État. Spécialement d'aprés les données fournies par le Droit Constitutionnel francais, París, Recueil Sirey, 1920. 
Este libro forma parte del acervo de la Biblioteca Jurídica Virtual del Instituto de Investigaciones Jurídicas de la UNAM

mularlas vinculadas a realidades vividas por los hombres de la época, trató de dar respuesta a problemas concretos.

Otra innovación de esta Constitución fue la de levantar una construcción radicalmente nueva no asentada sobre las antiguas libertades francesas, sino sobre el derecho natural y universal de individuos libres e iguales, haciendo que la organización de los poderes públicos fuera la expresión de esos derechos primarios de los individuos.

Comparada a sociedades anteriores, recurrir al derecho natural como fundamento de la constitución era una idea novedosa, pero que el fundamento de ésta pudiera residir en los derechos de los que eran titulares los individuos era una perspectiva muy ajena a la antigüedad.

Aparece así, en efecto, la novedad radical de esta Constitución y su enorme proyección: enuncia los principios que justifican las reglas atributivas de competencia - cosa que no hace la constitución norteamericana- y esos principios son los que permiten fundar una teoría del Estado. ${ }^{3}$

De esa larga lista de principios, desprendida de la Constitución francesa de 1791 y que han servido y sirven de fundamento o justificación al derecho positivo de Francia y de otros países, basta enumerar como ejemplo: la soberanía y la distinción entre su titularidad y sólo su ejercicio; la distinción entre Poder constituyente y poderes constituidos; la separación de poderes; la teoría de la ley como expresión de la voluntad general; el sistema representativo; el mandato representativo, etcétera.

La discusión llevada a cabo en el seno de la Asamblea Constituyente es absolutamente indispensable para comprender qué significa cada uno de los conceptos que convertidos en normas codificadas más tarde, sustentarían los principios teóricos de ese corpus doctrinal conocido como "constitucionalismo". Esto movió a Loewenstein a calificar a la Constituyente del 89 al 91 como el seminario de "Teoría política" más grande que jamás haya

3 Troper, Michel, "La constitution...", cit., p. 10. 
Este libro forma parte del acervo de la Biblioteca Jurídica Virtual del Instituto de Investigaciones Jurídicas de la UNAM

conocido el mundo. ${ }^{4}$ En este sentido, la celebración de su bicentenario estuvo plenamente justificada ya que los principios enunciados son capaces de brindar respuesta a numerosos problemas contemporáneos. ${ }^{5}$

Otra cuestión que debe destacarse es la profunda interdependencia entre lo que hoy conocemos como la parte dogmática y la parte orgánica de la Constitución, pues, aunque en su codificación misma aparezcan separadas, la discusión de una implicó la discusión de la otra. Como ya ha sido advertido, no es casual o simbólico que el artículo 3o. relativo a la soberanía o el artículo 16 que se refiere a la separación de los poderes aparezcan en la Declaración de los Derechos del Hombre y del Ciudadano: esto da testimonio de que los problemas orgánicos se discuten desde el inicio de los trabajos de la Constituyente y de que sus soluciones predeterminaron a las que más tarde se plasmarían, a propósito de otros problemas planteados. ${ }^{6}$

Es posible que sorprenda al lector el peso que en el presente trabajo se le da a las ideas de Sieyès. Pero, como me esforzaré en demostrar se trata del padre del derecho público francés.

"La verdad, dice Bastid, es que él lanzó a la circulación la mayor parte de las ideas sobre las cuales aún vivimos": Sieyès se ha convertido en un gran clásico del derecho público francés. “№ es lo propio de los grandes clásicos que los principios desprendidos de ellos entren en el patrimonio común, hasta el punto de parecer una invención colectiva, tanto se imprime gradualmente la traza de su origen individual?". ${ }^{7}$ Chevalier coincide

4 Pasquino, Pascuale, Sieyès et l'invention de la constitution en France, París, Ed. Odile Jacob, 1998, p. 213.

5 Verpeaux, Michel, "1791, première constitution française?", Revue française de droit constitutionnel, núm. 13, 1993, p. 5.

6 Perez Tremps, Pablo, "Presentación", en Duguit, León, La separación de los poderes y la Asamblea Nacional de 1789, Madrid, Centro de estudios constitucionales, 1996, p. VII.

7 Véanse Bastid, Paul, Sieyès et sa pensé, París, Hachette, 1970, pp. 307 y 308; "La place de Sieyès dans l'histoire des institutions", Revue d'Histoire Politique et Constitutionnelle, enero-marzo de 1939. 
Este libro forma parte del acervo de la Biblioteca Jurídica Virtual del Instituto de Investigaciones Jurídicas de la UNAM

con esta apreciación cuando afirma que Sieyès está presente en "casi todo lo que es profundo, esencial y durable de la ideología revolucionaria".8

Una cuestión para aclarar desde ahora es que la Constitución no fue redactada de una sola vez. Su redacción tomó más de dos años, puesto que la votación definitiva se llevó a cabo hasta la víspera de la disolución de la Asamblea Constituyente en septiembre de 1791 y esto se explica no sólo por la vehemencia de las discusiones, sino por las diversas crisis políticas que la afligieron y que ejercieron notable influencia en los giros y cambios que hubo en el debate y en las decisiones. Es llamado este periodo "observatorio excepcional", y así debe ser visto por quien quiera entender la mezcla de lo filosófico y lo circunstancial que caracterizó al trabajo de la Constituyente, y más allá de él, a toda la Revolución francesa. Esto también explica la dificultad de establecer una cronología, pues el tomar una decisión y volver los pasos sobre ella implicó un tejer y destejer de Penélope: si el 26 de agosto de 1789 fue votada la Declaración de Derechos, en octubre un cierto número de artículos y en diciembre el régimen electoral, para el verano del 90 pareció necesario hacer rectificaciones y no fue sino hasta agosto del 91 en que se abordara la discusión sobre el texto definitivo que culminó con el voto el 3 de septiembre que aprobó la Constitución.

Los estudiosos han establecido una periodización que divide en tres etapas la vida de la Constituyente. La primera se inicia con la instalación de los Estados Generales, el 5 de mayo de 1789 y va hasta las jornadas de octubre del mismo año. La segunda es la más larga y cubre ese otoño del 89, todo el año de 1790 y la primera mitad del 91, hasta la fuga de Varennes. La fuga del rey Luis XVI y su regreso constituye la tercera fase caracterizada por un esfuerzo de revisión de los textos ya elaborados. El trabajo concluyó el 30 de septiembre de 1791. De los tres periodos, a

8 Chevallier, Jean-Jacques, Histoire des institutions et des régimes politiques de la France de 1789 á nos jours, París, Dalloz, 1972, p. 27. 
Este libro forma parte del acervo de la Biblioteca Jurídica Virtual del Instituto de Investigaciones Jurídicas de la UNAM

decir de Furet, el primero es el más importante, porque es el que marca a los otros dos, aunque haya existido el intento de revisar lo votado. Son cuatro los votos esenciales que constituyen el marco filosófico dentro del cual la Constitución será erigida: el del 17 de junio, el del 4 de agosto, el del 26 de agosto y los del 10 y 11 de septiembre. ${ }^{9}$

9 Furet, François y Halevi, Ran, La Monarchie Republicaine, París, Fallard, 1996, pp. 171 y 172. El lector deseoso de obtener detalles sobre la composición de la Asamblea, sus métodos deliberativos, los lugares de la deliberación o de su reglamentación, puede consultar a Castaldo, André, Les Méthodes de travail de la Constituante. Les techniques delibératives de l'Assemblée Nationale 1789-1791, París, PUF, 1989. 
Este libro forma parte del acervo de la Biblioteca Jurídica Virtual del Instituto de Investigaciones Jurídicas de la UNAM

\section{LA CRISIS DEL ANTIGUO RÉGIMEN}

Los últimos años del antiguo régimen son el producto acumulado de una evolución que deviene en una organización social y política marcada por el signo del absolutismo.

El absolutismo monárquico se manifestó en una concentración enorme de poderes en manos del rey. Dueño absoluto de las funciones jurisdiccionales y legislativas era, además, el jefe sin control del ejecutivo y vale decir, de una burocracia altamente centralizada a la que nombraba y destituía.

Las expresiones corrientemente usadas en el lenguaje de la época son testimonio elocuente de esa concentración de las competencias y facultades estatales en manos del rey si veut le roi, si veut la loi, no tiene otro significado que la voluntad monárquica tenía fuerza de ley. Los edictos y ordenanzas solían ser rubricados por el rey con la frase car tel est notre plaisir. A tal punto se llegó a personalizar el poder y a confundir al monarca con las funciones del Estado que verdadera o no, la famosa sentencia del rey Sol, L'État c'est moi, da cuenta de una realidad. Así, no hay duda de que le bon plaisir du roi era lo que privaba. El origen divino del poder del rey era el fundamento jurídico e ideológico de este despotismo. En consecuencia, los reyes lo eran por voluntad providencial.

La voluntad divina no sólo era el fundamento de la autoridad, ya que además fijaba con carácter eterno los rangos en que se dividía la sociedad, estratos sociales con prerrogativas y deberes claramente diferenciados y delimitados. Esta organización social no era simplemente de hecho, sino que estaba basada en el derecho divino. No era el producto del consentimiento de los 
Este libro forma parte del acervo de la Biblioteca Jurídica Virtual del Instituto de Investigaciones Jurídicas de la UNAM

hombres, sino del reconocimiento unánime de esa jerarquía deseada por Dios. ${ }^{10}$

Entre las instituciones del antiguo régimen la que provocaba, sin duda, las críticas más vehementes y las más justificadas era la administración de justicia, pues ahí se causaban los escándalos más grandes y las iniquidades más dolorosas: el elevado número de jurisdicciones; el carácter hereditario o venal de los puestos; el costo de la justicia; la barbarie del procedimiento criminal; en fin, la severidad de las penas para la gente común y, en cambio, la indulgencia con los privilegiados motivaban la indignación generalizada.

El primer orden del reino, el clero - que garantizaba y sacralizaba como eterno el orden social, político e intelectualaseguraba diversos servicios públicos como: la asistencia a través de servicios hospitalarios; la enseñanza, ya que en sus planteles se educaban más de setenta y cinco mil estudiantes y el estado civil de las personas, dando fe de su nacimiento, matrimonio, muerte etcétera. Este era el verdadero y único orden, pues estaba organizado como tal, con sus normas y tribunales propios. Gran propietario inmobiliario era también poderoso económicamente, en razón de estar exento de pagar impuestos. Ahora bien, no estaba integrado por un grupo social coherente, pues sólo un pequeño grupo era el beneficiario verdadero de los privilegios: el alto clero, formado por personas provenientes de la nobleza. De igual forma, existía un bajo clero cercano a la población campesina y solidario de ella. ${ }^{11}$

El segundo orden, la nobleza, era la zona de concentración de los privilegios. Las reglas que la regían estaban consagradas por costumbres seculares, debiendo destacarse de entre ellas, el derecho de primogenitura. En la última etapa del Antiguo Régimen se habían operado ciertos cambios; de la antigua autoridad señorial conservaba hereditariamente sólo una parte de la justi-

10 Furet, François y Richet, Denis, La Revolution Francaise, París, Hachette, 1973, colección Pluriel, p. 18.

11 Ibidem, pp. 29 y 30. 
Este libro forma parte del acervo de la Biblioteca Jurídica Virtual del Instituto de Investigaciones Jurídicas de la UNAM

cia; la policía del villorrio; las prerrogativas honoríficas, como los lugares reservados en la Iglesia y monopolios como la caza y ciertos impuestos y derechos. ${ }^{12}$ Había desaparecido la parte política de esos derechos y sólo conservaba la porción pecuniaria que a veces había aumentado de manera considerable. ${ }^{13}$

Un fenómeno de importancia sería advertido lúcidamente por Tocqueville; a partir del reinado de Luis XIV, la nobleza sufrió una notable disminución en su papel de cuerpo intermediario entre el rey y el Tercer Estado. La centralización en beneficio de la corona le había reducido mucho su capacidad política. ${ }^{14}$ Por ello, la reivindicación liberal que reclamaba el control por cuerpos colegiados sobre el desmedido poder del rey, no sólo no le chocaba, sino que se avenía muy bien con la admiración que en la nobleza despertaban las instituciones inglesas.

El Tercer Estado representaba el 98\% de la población, calculada en la época en veintiséis millones de habitantes, con un $36 \%$ de menos de veinte años y un $24 \%$ de más de cuarenta. Es en el campo en donde residían más de las tres cuartas partes de la población del reino; la agricultura era de subsistencia, al tiempo que era comunitaria y basada en la pequeña explotación familiar. Sobre las espaldas de esta población pesaban de manera especial el impuesto real, el diezmo eclesiástico y los derechos señoriales, que se resentían tanto más injustos cuanto que no eran uniformes en todo el reino. ${ }^{15}$ Tocqueville explicaba la causa de este odio "tan grande" e "inextinguible" del campesino francés contra los derechos feudales en que éste se había constituido en propietario territorial y en que se había librado por completo del gobierno de su señor. "Si el campesino no hubiera poseído el suelo, habría permanecido insensible a varias de las cargas que el sistema feudal hacía pesar sobre la tierra ¿qué le importa el diezmo a quien

\footnotetext{
12 Ibidem, p. 28.

13 Tocqueville, Alexis de, El Antiguo Régimen y la Revolución, México, Fondo de Cultura Económica, 1996, p. 114.

14 Ibidem, p. 113.

15 Furet, François y Richet, Denis, La Revolution..., cit., p. 28.
} 
Este libro forma parte del acervo de la Biblioteca Jurídica Virtual del Instituto de Investigaciones Jurídicas de la UNAM

no es sino arrendatario?... ¿qué le importa la renta de la tierra a quien no es propietario del feudo?...". ${ }^{16}$ Coexistían también distintas burguesías de recursos financieros muy desiguales, pero todas marcadas por la discriminación secular de su nacimiento. ${ }^{17}$

Con excepción hecha de algunos nobles liberales, las contradicciones entre el grueso de la nobleza y el Tercer Estado eran insalvables. Sólo es explicable su alianza transitoria contra el absolutismo, por el repudio que la nobleza hizo, en nombre de la tradición señorial y en el afán de reivindicar el antiguo papel que jugaba antes de que la corona le arrancara el poder político. ${ }^{18}$

Interpretaciones recientes de la historia de la Revolución Francesa colocan sus orígenes en el largo plazo. Visualizan esos orígenes lejanos en la crisis sufrida por la sociedad de la antigua Francia medieval en los siglos XV y XVI; en la construcción de la monarquía absolutista y en la transformación social que ésta implicó, a partir de Richelieu y en los efectos diferidos de la doble revolución científica y filosófica del siglo XVII.

A ese notable cambio cultural dediquemos unas líneas, a fin de caracterizarla. La sociedad europea y particularmente la francesa del siglo XVII era estática, con una esperanza de vida terrena muy magra y, en cambio, con imaginativas expectativas de vida en el más allá. A la estructura social y política autoritaria e intolerante, aristocrática y jerárquica correspondían sujetos sometidos al respeto y a una resignación impuestos por la coacción y ordenados por la religión.

No obstante, después de crear la ciencia moderna, el racionalismo experimental pretendió en el siglo XVIII extender su imperio a todos los aspectos de la vida del hombre proveyendo a la burguesía de una filosofía que contribuyó, sobre todo en Francia, a despertar en ella la conciencia de clase y la audacia innovadora.

\footnotetext{
16 Tocqueville, Alexis de, op. cit., p. 116.

17 Furet, François y Richet, Denis, La Revolution..., cit., pp. 36-41.

18 Ibidem, p. 36.
} 
Este libro forma parte del acervo de la Biblioteca Jurídica Virtual del Instituto de Investigaciones Jurídicas de la UNAM

El progreso de la física y la mecánica, apoyadas en el método de investigación cartesiano, se acentuó con la obra de Newton y Locke, disipándose así la concepción mágica del universo. Helvetius, Holbach y Bentham laicizaron la moral e hicieron de ella una ciencia de las costumbres, fundándola en el interés del individuo y en la utilidad social. Por su parte, el derecho natural que se remontaba a los estoicos y que habían profesado ciertos teólogos de la Edad Media, habiendo sido arrumbado a la penumbra por el absolutismo en la mayor parte de los países continentales, sobrevivía, con todo, entre los calvinistas y Locke recurrió a él para legitimar la revolución de 1688: la sociedad que había sido fundada para salvaguardar la autonomía de las personas reposaba sobre el libre contrato de los ciudadanos; de igual forma, la autoridad del gobierno se asentaba sobre un contrato entre el pueblo soberano y su mandatario, y éste no debía usar su poder sino para hacer respetar los derechos imprescriptibles conferidos a los individuos por la divinidad.

Fue en Francia donde los filósofos combatieron con audacia la intolerancia y la censura del clero católico; como la autoridad de éste dependía del apoyo del poder temporal y de la adhesión de las clases dirigentes, aquéllos ridiculizaron con un verbo despiadado no sólo sus privilegios y vicios sino sus dogmas, desvaneciéndose el respeto que se les tenía.

Bajo el cuidado de Diderot, la Enciclopedia agrupó a los filósofos racionalistas en una especie de partido, del que El discurso preliminar de D’Alambert fue el manifiesto. Su obra crítica logró modificar la mentalidad a tal punto que, bajo Luis XVI, el protestante Necker accedió al gobierno, el aparato represivo cayó en desuso, los poderosos se desinteresaban en asistir a la misa y a la comunión, etcétera. Fue así que en Francia los privilegios y las supervivencias de la feudalidad, lo arbitrario y las imperfecciones de la administración monárquica se vieron más vehementemente combatidos.

Pero, habrá que señalar que la ofensiva no vino de la burguesía, sino de la aristocracia. Ésta no escapó a la influencia de los 
Este libro forma parte del acervo de la Biblioteca Jurídica Virtual del Instituto de Investigaciones Jurídicas de la UNAM

portavoces de la burguesía. Así, protegería la libertad civil contra el despotismo del que a veces sufría; la libertad económica aumentaría las ganancias que obtenía de sus grandes latifundios y la libertad política la seducía particularmente. ${ }^{19}$

Volviendo a las interpretaciones hay que decir que se resisten a reducirla a una explicación de tipo puramente estructural. Sus modalidades, afirman, no fueron inevitables porque estuvieran inscritas en las contradicciones sociales. Al contrario, insisten en restituir al hecho revolucionario mismo, al "acontecimiento", al hecho aparentemente fortuito, su papel creador en la discontinuidad histórica. No por depender del azar, piensan que los hechos meteorológicos deban ser minimizados, en cuanto a las consecuencias sociales y políticas que dejaron sentir sobre la población: las lluvias, las inundaciones, seguidas de sequías y de heladas hicieron de los alimentos bienes escasos y, en consecuencia, caros. Por otra parte, se consigna que el tratado de comercio francoinglés de 1786 abrió las puertas a una competencia que golpeó al sector textil y que redundó en desempleo y en alza de precios. ${ }^{20}$

Lo que parece haber desatado una catarata de acontecimientos fue la súbita alza de los precios y, de manera especial, los del trigo que redujo dramáticamente los ingresos de una población ya flagelada por el desempleo. En París el precio del pan se duplicó y en algunas regiones se triplicó y el descontento se elevó y se generalizó en razón directa a ello: aquí y allá aparecieron grupos de campesinos que asaltaban transportes de alimentos, robaban graneros, amenazaban a los señores que les reclamaban sus impuestos. El alza en los precios acarreó, al mismo tiempo, altos beneficios para los señores laicos o eclesiásticos, grandes propietarios de tierra, ya de suyo beneficiados por la caída salarial producto de una sobreoferta de mano de obra, causada ésta por

19 Lefebre, Geoges, La Revolution Francaise, París, PUF, 1963, pp. 65-81. De particular importancia es la obra clásica Casirer, Ernst, La Philosphie des Lumières, París, Fayard, 1966.

20 Furet, François y Richet, Denis, La Revolution..., cit., pp. 8-27. 
Este libro forma parte del acervo de la Biblioteca Jurídica Virtual del Instituto de Investigaciones Jurídicas de la UNAM

recientes cambios demográficos. De esta forma, el rencor social tenía un blanco bien delimitado: los órdenes privilegiados.

A todos estos problemas vino a sumarse lo que, en opinión de Soboul, fue la más importante de las causas inmediatas de la Revolución: la quiebra de las finanzas del Estado. El déficit financiero era, sin duda, el mal crónico de la monarquía, pero bajo el reinado de Luis XVI tuvo un agravamiento de proporciones catastróficas. A la percepción deficiente de ingresos del Estado, debido a los vicios del sistema fiscal y a la desigualdad en el cobro del impuesto, había que agregar el gasto excesivo superfluo de la corte y las guerras, en particular, los gastos realizados por la participación de Francia en la guerra de independencia de los Estados Unidos. Por supuesto que, para cubrir estos déficits se acudía a los préstamos, pero el servicio de la deuda ya comprometía a más de la mitad de los ingresos, de suerte que se daba la paradoja de que en los mejores años para la economía de un país, ya de suyo próspero, la hacienda estatal estuviera al borde de la quiebra. ${ }^{21}$

Durante ese último periodo del antiguo régimen, el rey acudió al expediente de cambiar varias veces de contralor general de finanzas; sin embargo, se cambiaba de persona en el seno del gabinete ministerial sin cambiar la receta, pues todos acudieron a los empréstitos que endeudaban más al Estado. En 1786 Calonne propuso un programa vasto de reformas y como sabía de antemano que no se lo registrarían los Parlamentos, ${ }^{22}$ acudió a la maniobra de convocar una "Asamblea de notables" de los que,

21 Soboul, Albert, Histoire de la Revolution Francaise, París, Idées, Gallimard, 1970, t. I, pp. 105-110.

22 En Francia se ubica la organización del Parlamento a partir de 1260. Poco más tarde, tiende a convertirse en una jurisdicción permanente que recibe del rey, la delegación de juzgar por él. Ante el crecimiento del dominio y el poder del rey, se hizo imposible que el Parlamento de París cumpliera sólo la tarea, por lo que se crearon varias cortes más en el país. Como juzgaban sobre las disposiciones tomadas por el Rey, se tomó la costumbre de registrarlas y así los parlamentos se arrogaron la facultad de registrar las ordenanzas y disposiciones del rey y, con el tiempo, se tomaron la libertad de actuar con independencia, 
Este libro forma parte del acervo de la Biblioteca Jurídica Virtual del Instituto de Investigaciones Jurídicas de la UNAM

por haber sido escogidos por el propio Calonne, éste esperaba su docilidad. Quedó conformada la Asamblea por prelados, grandes señores, parlamentarios, intendentes y consejeros de Estado, etcétera; quienes tuvieron, por lo contrario, una actitud inesperada, pues defendieron sus privilegios, protestaron contra los abusos, exigieron el examen de las cuentas del tesoro y negociaron su voto a cambio de concesiones políticas. Ante el fracaso, Calonne fue despedido, mas el nuevo responsable - Brienne - tampoco tuvo suerte porque, finalmente, la Asamblea de notables se declaró incompetente para aprobar los impuestos.

La urgencia de las reformas para poder obtener más ingresos impulsó a Brienne a convocar entonces a los Parlamentos, aunque a la resistencia de los notables, siguió la de los Parlamentos: para subsistir Brienne necesitaba de más empréstitos, pero no podía contratarlos sin obtener el asentimiento de los Parlamentos que no lo concedieron, sino a cambio de la promesa de convocar a los Estados Generales. Reducido a la impotencia, ante la alianza del Tercer Estado con los privilegiados, se vio obligado a renunciar y el rey volvió a llamar a Necker, quien iría a impulsar la rendición total del sistema absolutista. ${ }^{23}$

No era la primera crisis en la que la anarquía parecía substituir a la autoridad, lo que había de novedoso era que por primera vez se le trataba de encontrar una salida política: parecía haberse formado un frente unido del Tercer Estado contra los privilegios de los otros dos órdenes, contra la base del impuesto y por una reforma del Estado tradicional. Así, a la crisis económica se superpuso la política y ambas se reforzaron recíprocamente. ${ }^{24}$

Con todo iría a fraguarse una transitoria y frágil coincidencia entre el Tercer Estado y los dos órdenes privilegiados, la cual se explica en el cálculo que éstos hacían de que los Estados Generales irían a ser convocados en la misma forma que en 1614, en tres

rechazando el registro de aquéllas con las que no estaban de acuerdo. Cfr. Ellul, Jacques, Histoire des Institutions, París, PUF, 1969, t. III, pp. 270-337.

23 Soboul, Albert, op. cit., pp. 111-123.

24 Furet, François y Richet, Denis, La Revolution..., cit., pp. 60 y 61. 
Este libro forma parte del acervo de la Biblioteca Jurídica Virtual del Instituto de Investigaciones Jurídicas de la UNAM

órdenes separados, disponiendo cada uno de un voto. La victoria de los privilegiados sobre el Tercer Estado estaba asegurada: la convergencia táctica de los privilegiados se basaba en la apuesta de que así se contendrían las reivindicaciones igualitarias del Tercer Estado. Se trataba de aceptar la convocatoria a la Asamblea para llevar a cabo cambios para que todo quedara igual. ${ }^{25}$

El reglamento que el gobierno emitió para regular las elecciones, por las que iría a designarse a los diputados a los Estados Generales preveía la celebración de asambleas electorales separadas por estamento que tendrían lugar en la cabecera de la circunscripción o en el barrio, o corporación en las ciudades, o en las parroquias en el campo. El voto tendría lugar nominalmente en la Asamblea Electoral, después de que se habría deliberado para redactar el cahier de dolèances o cuaderno de quejas. Cada asamblea redactó el suyo, y como la nobleza y el clero no tenían más que una asamblea por circunscripción, no redactaron más que un único cuaderno que los diputados transmitirían. La asamblea de circunscripción del Tercer Estado compuso un cuaderno donde fundía al conjunto de cuadernos de las parroquias y ciudades, ellos mismos suma de los cuadernos de corporaciones y de barrios. ${ }^{26}$

De la lectura de los cuadernos se desprende una coincidencia de los tres órdenes en contra del absolutismo. Curas, nobles y burgueses demandaban una Constitución, el establecimiento de una representación que aprobara los impuestos y las leyes y el cuidado de la administración local en manos de asambleas provinciales electivas. También estaban de acuerdo en solicitar la reforma fiscal, la de la justicia y las garantías de libertad y de libertad de prensa. Ahora bien, los cuadernos del clero guardaban silencio sobre la cuestión de los privilegios y sobre la libertad de conciencia, cuando no la rechazaban abiertamente. Los de la nobleza defendían el voto por orden, como la mejor garantía de los privilegios, en cambio aceptaban la igualdad fiscal, pero la

25 Ibidem, p. 36. Cfr. Soboul, Albert, op. cit., p. 123.

26 Soboul, Albert, op. cit., pp. 140-142. 
Este libro forma parte del acervo de la Biblioteca Jurídica Virtual del Instituto de Investigaciones Jurídicas de la UNAM

mayor parte rechazaba la igualdad de derechos y la admisión de todos a los empleos. El Tercer Estado, en conjunto, reclamaba la igualdad civil integral, la abolición del diezmo y la supresión de los derechos feudales, aunque muchos cuadernos se limitaban a solicitar su redención por compra. ${ }^{27}$

\section{LAS LEYES FUNDAMENTALES DEL ANTIGUO RÉGIMEN Y LA NUEVA IDEA DE CONSTITUCIÓN}

Puesto que en los cuadernos de quejas se plasmaba el deseo coincidente de los tres órdenes de que hubiera una Constitución, y dado que mayoritariamente estos cuadernos estimaban que el malestar político, económico y social que Francia sufría provenía del hecho que no poseía una Constitución, conviene aquí abrir un paréntesis que trate de explicar qué se entendía por Constitución y si se puede decir que en el antiguo régimen hubiera una Constitución.

Con objeto de no suscitar equívocos con una lectura anacrónica, es indispensable aclarar, desde el principio, que no existía un texto escrito equivalente a una Constitución moderna; que las relaciones entre los poderes no estaban consignadas en una norma jurídica merced a esa pretendida Constitución; que esta hipotética Constitución fuera el producto de una voluntad formal, positiva, explícita; tampoco puede decirse que procedía de una operación legislativa fundante, siguiendo un procedimiento especial. En otros términos, no era la obra de un poder constituyente establecido específicamente para tal fin; no era susceptible de revisión y no se preveía sanción alguna en caso de violación. ${ }^{28}$

Si se toma en este sentido formal, meramente jurídico y moderno de concebir una Constitución, les asistía la razón a los revolucionarios que se propusieron repudiar el antiguo régimen y edificar una "Constitución sin madre", porque efectivamente, el antiguo régimen carecía de ésta. Para ellos, esta carencia era la

27 Ibidem, pp. 142 y 143.

28 Furet, François y Halevi, Ran, La Monarchie..., cit., pp. 32 y 33. 
Este libro forma parte del acervo de la Biblioteca Jurídica Virtual del Instituto de Investigaciones Jurídicas de la UNAM

prueba irrecusable de la iniquidad, de la corrupción, de la confusión de principios, de lo arbitrario que prevalecía en el régimen que trataban de derruir. ${ }^{29}$

Había en ellos la clara intención política de negarle existencia a una realidad: una Constitución orgánica, tradicional, que expresara "el orden natural de las cosas políticas" que reconociera derechos, sin fijarlos forzosamente en un lenguaje normativo y que, más que definir un procedimiento para la devolución y el ejercicio del poder, diera cuenta de él. Esa realidad era, según la expresión de algunos, "una vida y no un texto de ley", "un organismo más que un mecanismo". ${ }^{30}$ "La antigua constitución, pues, no procedía de un acto fundacional susceptible de conmemoración o repudio. No había nacido de una "voluntad constituyente", ni de un acto contractual o pacto, ni de una concesión real. Era una "manera de ser" el modo de existencia política de la nación francesa, una comunidad de obligaciones formadas por el uso y consagradas por el tiempo, que algunas veces introducía ciertos cambios. ${ }^{31}$

Maistre, vocero nostálgico del absolutismo, expresaría años más tarde, el reclamo a los revolucionarios por haber negado la existencia de una Constitución, pero la idea que se hacía de ella era una noción de Constitución alejada de la que la concibe como un instrumento político de la libertad y la igualdad, se trataba — según él — de "un modo de existencia querido por Dios" para la nación. La Constitución no debía nada a la voluntad de los hombres - agregaba - porque el hombre no puede crear nada que no exista ya. Para él, pensar que la Revolución había dado a Francia una Constitución era tanto como ceder a la quimera pretenciosa de los modernos de creer que el hombre es el principio de las cosas políticas, tal fue, concluía, "la ilusión criminal" de los enterradores de la monarquía absoluta, que pre-

29 Ibidem, p. 16.

30 Ibidem, p. 33.

31 Ibidem, p. 39. 
Este libro forma parte del acervo de la Biblioteca Jurídica Virtual del Instituto de Investigaciones Jurídicas de la UNAM

tendían fundar otro régimen por un puro acto de voluntad, tal fue "el muy funesto error", "la loca empresa" de los antiguos parlamentos, que intentaron reconducir a la constitución, como si les fuera dado modificar el diseño divino. ${ }^{32}$

Una variante de esta opinión sería la del acervo crítico inglés de la Revolución, Burke, quien al concebir cualquier Constitución como el producto de una historia siempre particular - como conjunto de títulos, de instituciones, de experiencias, etcétera, que modelan a través de las edades el patrimonio intangible de la Nación - afirmaba que la Francia del antiguo régimen disponía de todos los elementos de una Constitución, tan buena como la mejor que se pudiera desear. Sin embargo, agregaba que esta constitución desde hacía largo tiempo estaba "suspendida", "degradada", con lo que lanzaba implícita, no obstante, inequívocamente, una condena firme al sistema absolutista y empujaba hacia la restauración del tradicional edificio constitucional y al restablecimiento de los antiguos Estados Generales, abolidos por el absolutismo. ${ }^{33}$

Sin embargo, la opinión más conspicua de los nuevos tiempos sobre el tema de la existencia o no de una Constitución y que revela el avance de la conceptualización sobre lo qué es una Constitución, la daría Mounier - monarquista, insospechable de inclinaciones revolucionarias - al rendir un primer informe del comité encargado por la Asamblea de establecer el orden de trabajo sobre la Constitución.

...pensamos que una constitución no es otra cosa que un orden fijo y establecido en la manera de gobernar; que este orden no puede existir si no está apoyado sobre reglas fundamentales, creadas por el consentimiento libre y formal de una nación o de aqué-

32 Ibidem, p. 23. Así como Maistre, Joseph de, Écrits sur la Révolution, París, PUF, 1989, pp. 141 y ss.

33 Ibidem, pp. 25 y 26. Cfr. Burke, Edmund, "Reflexiones sobre la Revolución francesa 1790", Textos Políticos, México, Fondo de Cultura Económica, 1942, pp. 151 y ss. 
Este libro forma parte del acervo de la Biblioteca Jurídica Virtual del Instituto de Investigaciones Jurídicas de la UNAM

llos que ella escogió para representarla. Así, una constitución es una forma precisa y constante de gobierno, o si se quiere, la expresión de los derechos y obligaciones de los diferentes poderes que la componen... Cuando la manera de gobernar no deriva de la voluntad del pueblo claramente expresada se carece de constitución; no hay más que un gobierno de hecho que varía según las circunstancias, que cede a todos los acontecimientos. Entonces la autoridad tiene más fuerza para oprimir a los hombres que para garantizar sus derechos. Los que gobiernan y los que son gobernados son igualmente desgraciados...

En una clara ligazón entre Constitución y atribución de poderes o facultades en manos diferentes y en una terminante condena a la confusión de los poderes, dice: "no tenemos [en Francia] una forma determinada y completa de gobierno. No tenemos una constitución, puesto que todos los poderes están confundidos, puesto que no se ha trazado ningún límite... El establecimiento de una autoridad real no basta, sin duda, para crear una constitución: si esta autoridad no tiene límites es necesariamente arbitraria y nada está más directamente opuesto a una constitución que el poder despótico...".

Más adelante, revelando un claro conocimiento de la distinción hecha por Sieyès, tiempo antes advierte: “...es imposible confundir la organización de poderes del Estado con sus reglas emanadas de la legislación... Actuaremos como constituyentes, en virtud de los poderes que hemos recibido; ocupándonos de las leyes, actuaremos simplemente como constituidos".

En un párrafo subsecuente, puso de manifiesto no sólo la primacía que los liberales concedían a los derechos individuales, sino que ya se prefiguraba la distinción moderna en las Constituciones de la parte dogmática respecto de la parte orgánica: "para que una constitución sea buena, es necesario que esté fundada sobre los derechos del hombre y que los proteja evidentemente... El comité ha creído sería conveniente, para recordar el fin de nuestra constitución, de hacerla preceder por la declaración 
Este libro forma parte del acervo de la Biblioteca Jurídica Virtual del Instituto de Investigaciones Jurídicas de la UNAM

de los derechos de los hombres, pero de colocarla en forma de preámbulo, antes de los artículos constitucionales y de no hacerlo separadamente...". ${ }^{34}$

Los diputados de la Asamblea Constituyente de 1789-1791 no se plantearon regenerar al reino recuperando las antiguas libertades contenidas en una hipotética constitución primitiva o histórica, sino que se propusieron construir un edificio totalmente nuevo. Una vez superadas las ambigüedades provocadas por la convocatoria a los Estados Generales, la Asamblea Nacional descubrió lo que constituía la piedra angular de la edificación por levantar, esto es, habría que asentar la Constitución misma sobre el derecho natural. La Constitución se erigió, pues, sobre el derecho natural y la organización de los poderes públicos no fue otra cosa que la expresión de los derechos primigenios de los individuos. Esto es lo que explica que la Declaración de los Derechos del Hombre y del Ciudadano de 1789 preceda al texto constitucional y no venga a modelarlo a posteriori. Es también, igualmente por qué el principio de soberanía está imbricado con la libertad misma de los hombres, de donde se desprende la exigencia de ser gobernados por dirigentes que mediata o inmediatamente representen a los gobernados..$^{35}$

El autor que - a mi juicio - complementa la aclaración sobre la aparentemente inexplicable ubicación de la afirmación de la soberanía nacional o la de la supremacía de la ley en la celebrada Declaración de 1789 es Fioravanti.

La cultura individualista de las libertades valora positivamente el papel desempeñado por el Estado, como máxima concentración del imperium en la lucha contra la sociedad estamental y privilegiada y no puede dejar de reconocer la necesidad de un

34 Mounier, "Rapport du Comité chargé du travail sur la Constitution (9 de julio de 1789)", Orateurs de la Revolution Francaise (textos escogidos, presentados y anotados por Furet y Halévi), París, Gallimard, 1989, colección Biblioteca de las Pléyades, t. I: Les Constituants, pp. 863-869.

35 Troper, Michael y Jaume, Lucien, “Avant-propos. Une nouveauté...”, cit., pp. 14 y 15. 
Este libro forma parte del acervo de la Biblioteca Jurídica Virtual del Instituto de Investigaciones Jurídicas de la UNAM

legislador fuerte y dotado de autoridad que delimite y garantice con seguridad la esfera de cada uno.

La Declaración de 1789 remite a la ley y a la autoridad del legislador. Se constata la convicción que la ley general y abstracta es el instrumento idóneo para la garantía de los derechos. Se es libre porque se está gobernado de manera no arbitraria, porque en materia de derechos y libertades no vale ya la voluntad de un hombre contra la de otro, porque son abolidas la dominaciones de carácter personal, porque sólo la ley puede disponer de nosotros mismos.

En dicha Declaración, dice Fioravanti, existen sólo dos valores político-constitucionales: el individuo y la ley como expresión de la soberanía nacional. Al artículo 2o. que establece "el fin de toda asociación política es la conservación de los derechos naturales e imprescriptibles del hombre", corresponde el artículo 3o. que establece "el principio de toda soberanía reside esencialmente en la nación. Ninguna corporación o individuo puede ejercer una autoridad que no emane expresamente de ella". Los dos artículos juntos - dice - fijan las coordenadas generales de un modelo político que al mismo tiempo libera al individuo y al Estado - este último expresado en los términos de la soberanía nacional- de la presencia embarazosa de los viejos poderes feudales y señoriales. La afirmación de los derechos naturales del individuo y la de la soberanía nacional - continúa - no son realidades opuestas. Al contrario, ambas se toman como hijas del mismo proceso histórico, que al mismo tiempo que libera al individuo de las antiguas ligaduras del señor-juez o del señor-recaudador, libera también al ejercicio del poder público en nombre de la nación de las influencias en sentido disgregante y particularista de los poderes feudales y señoriales. ${ }^{36}$

36 Fioravanti, Mauricio, Los derechos fundamentales. Apuntes de historia de las constituciones, Madrid, Trotta, 2003, pp. 46, 58 y 70. 
Este libro forma parte del acervo de la Biblioteca Jurídica Virtual del Instituto de Investigaciones Jurídicas de la UNAM

\section{LAS PRIMERAS EXPERIENCIAS \\ EN EL DEBATE GONSTITUCIONAL}

Renovando una tradición pre-absolutista, Luis XVI convocó a los Estados Generales para sesionar el 5 de mayo de 1789. Esta tradición se había visto interrumpida en 1614, fecha de la última reunión de este organismo, bajo la minoría de Luis XIII.

En la convocatoria, el Rey no precisó si las modalidades consagradas por una tradición secular serían observadas; es decir, si las deliberaciones y las votaciones se llevarían a cabo también separadamente por orden y si iría a haber un mismo número de diputados por orden. Este silencio, que parecía no tomar partido, provocó reacciones diversas. Los dos órdenes privilegiados se inquietaron ante una posible innovación que pusiera en entredicho su tradicional hegemonía y exigieron que la convocatoria a los Estados Generales fuera hecha regularmente y de acuerdo a la forma observada en 1614. Por su parte, el Tercer Estado planteaba que el número de sus diputados fuera el doble del resto y que el voto fuera por cabeza y no por orden.

Los argumentos más contundentes para fundar la postura del Tercer Estado los proporcionaría Sieyès, no sólo en su célebre y difundido panfleto ¿Qué es el Tercer Estado?, lo que le valdría ser diputado por ese orden, sino también en su primer trabajo dedicado a este tema.

Desde la introducción misma de ese su primer trabajo revela su método y fundamentos: el rechazo a utilizar el peso de la historia como argumento de autoridad, lo que contaba para él era la razón, la lógica: aceptar la historia y la tradición era aceptar los antiguos usos y prácticas feudales, que daban lugar preeminente a los órdenes privilegiados. Por otra parte, apelaba a la necesidad de dar a la nación una Constitución como única forma de garantizar a los ciudadanos el gozo de sus derechos naturales y sociales. Llama la atención que al referirse a los Estados 
Este libro forma parte del acervo de la Biblioteca Jurídica Virtual del Instituto de Investigaciones Jurídicas de la UNAM

Generales, ya de temprana fecha se refiera a ellos también como Asamblea Nacional. ${ }^{37}$

El hilo conductor de su reflexión se centró en dos preguntas ¿Dispondrán los Estados Generales de los suficientes medios de ejecución? ¿Los tendrán de manera segura? Para responder a ellas desarrolló su alegato en tres secciones: los Estados Generales tienen el derecho a legislar; no pertenece más que a los Estados Generales ejercer el Poder Legislativo y los Estados Generales pueden establecer y hacer permanente e indispensable el resultado de sus deliberaciones. ${ }^{38}$ Es mi opinión que, a pesar de su rechazo a recoger la experiencia histórica, de principio a fin, en la elaboración de la estrategia política que propone en su argumentación utiliza la experiencia del Parlamento inglés, que teniendo como única arma de presión la facultad impositiva, había sabido arrancar al Ejecutivo competencias y poderes - entre otros, el fundamentalísimo de elaborar las leyes - hasta conformar un sistema constitucional equilibrado. También, cabe aclarar para contextualizar esta discusión, que los Estados Generales eran una asamblea cuyo origen se remontaba a la Edad Media. Este órgano colectivo no contaba con la menor posibilidad de reformar nada, pues no poseía ni una sola parcela del Poder Legislativo. Su único título jurídico era la convocatoria real. Podía hacer observaciones, dar consejos, consentir los impuestos, pero nada más. ${ }^{39}$

En la primera sección, atacó el tema de las contribuciones y a quién pertenecía la facultad de imponerlas. Para él, la ley creaba obligaciones. El fisco podía perseguir al contribuyente al que la ley obligaba y la fuerza pública podía asegurar su ejecución, pero la ley no era obra del fisco ni de la fuerza, la ley no era más que la voluntad de quien tenía el derecho de obligar. Concluyó afirmando

37 Sieyès, Emmanuel-Joseph, "Consideraciones sobre los medios de ejecución de los cuales los representantes de Francia podrán disponer en 1789”, en Pantoja Morán, David (comp.), Escritos políticos de Sieyès, México, Fondo de Cultura Económica, 1993, pp. 63 y 64.

38 Ibidem, p. 65.

39 Ferrero, Guglielmo, Les Deux Revolutions Francaises, Boudry, Ed. de la Baconnière, 1951, p. 20. 
Este libro forma parte del acervo de la Biblioteca Jurídica Virtual del Instituto de Investigaciones Jurídicas de la UNAM

que sólo la nación podía obligar al contribuyente y que este aspecto de la facultad legislativa pertenecía a los Estados Generales. ${ }^{40} \mathrm{Se}$ puede considerar que Sieyès hizo aquí una notable contribución, que obra como precedente del decreto de 17 de junio de 1789, "para asegurar la percepción de los impuestos y el pago de la deuda pública". En este decreto se consignó uno de esos principios calificados de constitucionales, para siempre sacralizados y auténticamente reconocidos por el rey y proclamados solemnemente por todas las asambleas de la nación: el del consentimiento de los impuestos por los representantes de la nación. Verpeaux se pregunta si este decreto no es en el contexto de junio de 1789 el más importante de entre los que pensaban los futuros constituyentes. ${ }^{41}$

Se libró, enseguida, a una larga e importantísima discusión sobre los principios que sustentan al sistema representativo (que será objeto de análisis más adelante) para rematar con una afirmación que con la argumentación anterior arroja luz sobre la asimilación que hace de los Estados Generales con la Asamblea Nacional, “...una asamblea general de representantes es el órgano legítimo de la voluntad nacional ...con esta condición tiene el derecho de dar leyes a todo aquello que pertenezca a la nación y no hay nada que escape a su poder...". 42

En la segunda sección reivindicó para los Estados Generales la exclusividad del ejercicio de la facultad legislativa. Al constatar que los Estados Generales habían sido convocados para autorizar un impuesto nuevo, instó a este cuerpo colegiado a no desaprovechar "...la ocasión más favorable y la menos costosa que haya sido ofrecida a un pueblo de adquirir una constitución libre...".43 En su opinión, esta ocasión se perdería si los Estados Generales se limitaban a suscribir la bancarrota. Si el rey no tenía el dere-

40 Sieyès, Emmanuel-Joseph, "Consideraciones sobre los medios...", cit., p. 66 .

41 Verpeaux, M., op. cit., pp. 6 y 7.

42 Sieyès, Emmanuel-Joseph, "Consideraciones sobre los medios...", cit., p. 71 .

43 Ibidem, p. 82. 
Este libro forma parte del acervo de la Biblioteca Jurídica Virtual del Instituto de Investigaciones Jurídicas de la UNAM

cho, ni el poder de decretar la bancarrota era porque no era él el endeudado o el que proveía los fondos para liquidar las deudas, era la nación; las riquezas anuales destinadas a solventar los trabajos y las deudas eran la producción de los ciudadanos. ${ }^{44}$ De la misma manera, era la nación a quien correspondía establecer un ingreso público con el conocimiento que tenía de las necesidades públicas. “'Tiene necesidad, pregunta, de una opinión que no sea la suya para saber que hay gastos comunes que hacer y que no pueden liquidarse más que por medio de un subsidio determinado por las cuotas y la duración?" 45

En la tercera sección alertó sobre el peligro de la desaparición de las leyes y medidas benéficas tomadas, una vez disueltos los Estados Generales. Aseguró que la mejor forma de evitarlo era teniendo una Constitución, ya que "es por ahí por donde hay que comenzar... una constitución es la única base de toda reforma, de todo orden y de todo bien". Pero, se preguntaba, "¿esta constitución con la que nosotros garantizamos los estatutos nacionales, quién la garantizará a ella misma? Ya es tiempo de responder: la nueva ley del impuesto... queremos hablar de una ley de impuestos que ella misma sea constitucional ...de tal manera que la constitución y el impuesto queden estrechamente ligados en todos sus puntos y no puedan jamás separarse". Sólo así - aseguraba - todas las partes de la Constitución tendrán consistencia final y autoridad, porque si el Poder Ejecutivo mismo, poder del que había que precaverse, "no puede prescindir del impuesto, tendrá que respetar la ley constitucional en virtud de la cual el impuesto será recaudado". ${ }^{46}$

Sus argumentos en el famoso panfleto ¿Qué es el Tercer Estado? Irían a ser definitivos.

¿Quién se atrevería a decir que el Tercer Estado no tiene en sí todo lo que es preciso para formar una Nación completa? Es el

$44 \quad$ Ibidem, p. 80.

45 Ibidem, p. 77.

46 Ibidem, pp. 95 y 96. 
Este libro forma parte del acervo de la Biblioteca Jurídica Virtual del Instituto de Investigaciones Jurídicas de la UNAM

hombre fuerte y robusto del que un brazo está todavía encadenado. Si se le despojase de la clase privilegiada, la Nación no vendría a menos, sino que iría a más. Así, ¿qué es el Tercer Estado? Todo, pero un todo trabado y oprimido. ¿Qué sería el Tercer Estado sin la clase privilegiada? Todo, pero un todo libre y floreciente ${ }^{47}$...Pero ¿de qué le serviría asistir a los Estados Generales, si ahí predomina un interés contrario al suyo? No haría más que consagrar con su presencia la opresión de la que es eterna víctima. Así, el Tercer Estado está bien seguro de que no puede venir a votar en los Estados Generales si no tiene en ellos una influencia al menos igual a la de los privilegiados, y pide un número de representantes al menos igual a la de las otras clases juntas. En fin, esta igualdad llegaría a ser perfectamente ilusoria si cada Cámara tuviese su voto separado. El Tercer Estado pide, pues, que los votos sean por cabeza y no por clase.

Más adelante, basado en números quizá no muy precisos, intentó un cálculo sobre la población del país, separada por órdenes y comparó los doscientos mil individuos que eventualmente integrarían los dos primeros órdenes privilegiados con los veinticinco o veintiséis millones de habitantes de la Francia de entonces. Bajo este supuesto se preguntaba:

¿qué le queda por hacer al Tercer Estado si quiere entrar en posesión de sus derechos políticos de una manera útil a la Nación? Para lograrlo se presentan dos medios. No concurrirá con la nobleza y el clero, ni permanecerá con ellos ni por clases ni por $c a^{-}$ bezas. Yo pido que se preste atención a la diferencia enorme que existe entre la asamblea del Tercer Estado y la de las otras clases. La primera representa veinticinco millones de hombres y delibera sobre los intereses de la Nación. Las otras dos no reciben poderes más que de unos doscientos mil individuos, y no tienen más preocupación que sus privilegios. El Tercer Estado - se nos dirá- no puede por sí sólo formar los Estados Generales. ¡Tanto

47 En la versión en español el traductor modernizó el término ordre y lo hizo equivaler al de "clase", pero sería más preciso utilizar estamento u orden, y es en ese sentido que se entiende en este trabajo. 
Este libro forma parte del acervo de la Biblioteca Jurídica Virtual del Instituto de Investigaciones Jurídicas de la UNAM

mejor! — responderemos - así compondrá una Asamblea Nacional. ...Si les dejáis deliberar en las materias de interés general [al clero y a la nobleza] ¿qué resultaría? Veamos: 1) si los votos son emitidos por clases resultará que veinticinco millones de ciudadanos no podrán decidir nada a favor del interés general, si ello no agrada a doscientos mil individuos privilegiados; es decir, que las voluntades de más de cien personas serán aniquiladas por la voluntad de una sola. 2) si los votos son emitidos por cabezas, e incluso en igualdad de influencia entre los privilegiados y los no privilegiados, ocurrirá igualmente que las voluntades de doscientas mil personas podrán anular las de veinticinco millones, pues que ellas tendrán un número igual de representantes. Ahora bien: ¿no es monstruoso el hecho de componer una asamblea de manera que pueda votar en favor del interés de una minoría? ¿no resulta a la inversa siempre una asamblea?... ${ }^{48}$

Para dar signos de buena voluntad, Luis XVI llamó a Necker al ministerio y éste, a su vez, cedió en la petición de que la representación del Tercer Estado duplicara en número al de los otros dos órdenes, pero nada dijo sobre el voto por orden, cuyo mantenimiento anularía la anterior concesión. Otro punto que es relevante es el reglamento de la convocatoria a Estados Generales del 24 de enero de 1789, que ya prefiguraba un vuelco dramático: el de la igualdad política de los individuos-electores, aunque todavía se situaba entre la representación corporativa tradicional y la representación individualista moderna. Se adoptaron condiciones muy poco restrictivas para poder votar para elegir representantes de segundo grado, encargados a su vez de nombrar diputados para los Estados Generales, pero el principio de sufragio individual era casi sin restricciones. Aunque era todavía una forma de igualdad prepolítica y predemocrática, aún cercana a la representación por estamentos. No era la afirmación de un derecho político individual, sino la reafirmación del poder

48 Sieyès, Emmanuel-Joseph, “¿Qué es el Tercer Estado?”, en Pantoja Morán, David (comp.), Escritos políticos de Sieyès, México, Fondo de Cultura Económica, 1993, pp. 131, 136, 142, 166 y 168. 
Este libro forma parte del acervo de la Biblioteca Jurídica Virtual del Instituto de Investigaciones Jurídicas de la UNAM

monárquico que se nutría directamente del consentimiento de sus súbditos. El sufragio, paradójicamente, fue más amplio en abril de 1789 que en 1791, después de ser aprobada la Constitución; sin embargo, no por ello más democrático, su finalidad era otra, pues se trataba de organizar asambleas corporativas cuya misión era la recepción de quejas. ${ }^{49}$

Finalmente, la apertura de los Estados Generales se llevó a cabo en la fecha fijada, en Versalles en la sala del edificio conocida como "Menus-Plaisirs". Los diputados y el público, con la cabeza descubierta y de pie, escucharon el discurso de inauguración del rey. Esta alocución no contenía la definición esperada y sólo es de retener de ella el que el rey se refiriera a los integrantes de los Estados Generales como "representantes de la nación"; el que diera seguridades de haber ordenado considerables recortes en el gasto para hacer frente al déficit fiscal y el que expresara el deseo de que se propusieran medios eficaces para establecer orden permanente en las finanzas públicas. ${ }^{50}$ Barentin, el garde des sceaux, ${ }^{51}$ les alentó a ocuparse de muchos tópicos: del restablecimiento de las finanzas, de la seguridad pública, de la libertad de prensa, de la legislación criminal, de los procedimientos civiles y del mejoramiento de la educación, salvo de las instituciones políticas y mucho menos de tratar de reformarlas. ${ }^{52}$ Cerró Necker con un discurso largo que dejó insatisfecho a todo mundo, especialmente al Tercer Estado, pues si bien, de forma obscura, se refirió a la necesidad de establecer "un nuevo orden", no respondió a las cuestiones acuciantes sobre las deliberaciones y el voto en el seno de los Estados Generales. ${ }^{53}$

49 Rosanvallon, Pierre, La consagración del ciudadano. Historia del sufragio universal en Francia, México, Instituto Mora, 1999, pp. 51-54.

50 Cfr. "Discours du Roi á la ouverture des États Généraux (5 de mayo de 1789)", en Furet, François y Halévi, Ran, La Monarchie..., cit., pp. 290 y 291.

51 El guardián del sello en la antigua tradición francesa era el funcionario que cumplía funciones equivalentes a las de un actual ministro del interior y al ministro de justicia.

52 Furet, François y Halévi, Ran, La Monarchie..., cit., p. 114.

53 Ibidem, pp. 114 y 115. 
Este libro forma parte del acervo de la Biblioteca Jurídica Virtual del Instituto de Investigaciones Jurídicas de la UNAM

Con su indecisión la monarquía se debilitó. Ordenar las sesiones y el voto separado de las órdenes le hubiera granjeado el apoyo de la nobleza y del clero; ordenar las deliberaciones y el voto conjuntos, el del Tercer Estado. Pero al optar por la indefinición, se enajenó de esas bases de sustento. Se abrió entonces un paréntesis largo de seis semanas de infructuosas mediaciones para llegar a un acuerdo, pero la diferencia se antojaba inzanjable, pues la mayoría de la nobleza y la de los prelados no deseaban la deliberación en común, el rey tampoco la aceptaba ${ }^{54}$ y el Tercer Estado no podía ceder, so pena de perder lo obtenido, de haber duplicado el número de sus representantes sobre el de los otros dos órdenes.

En vez de lanzarse al enfrentamiento rechazando el voto por orden, el Tercer Estado optó por esperar y no se constituyó en asamblea, ni se dio reglamento interno, ni formó directiva; sin embargo, decidió adoptar como nombre "diputados de los comunes". El diferendo con los otros órdenes, mientras tanto, operaba a favor de la cohesión, de la forja de un espíritu colectivo, en el que se irían distinguiendo talentos y autoridades como Sieyès, Mirabeau, Bailly, Target, Barnave, Mounier, etcétera.

Intentando precipitar las cosas, la nobleza se declaró constituida en asamblea y, más tarde, declaró que la deliberación por orden y la facultad de impedir, que divididamente tenían los órdenes, eran "constitutivas de la monarquía". En la controversia la nobleza mezclaba intencionadamente dos cuestiones diferentes, una, meramente de procedimiento y, otra, de índole política y constitucional de fondo. Efectivamente, la primera consistía en saber si se verificaría en común o por separado la validez de las elecciones y la otra en si se revisaría o no el contenido de los mandatos; es decir, la materia que una vez constituida la asamblea iría a ser objeto de la discusión constitucional.

54 Ferrero difiere de esta interpretación. Afirma que el silencio del rey significaba que dejaba la decisión a la asamblea de los Estados Generales y que no se oponía a que las deliberaciones tuvieran lugar en común y que el voto fuera por cabeza. En suma, que el gobierno se mantenía como "un espectador desinteresado del conflicto". Cfr. Ferrero, Guglielmo, op. cit., p. 19. 
Este libro forma parte del acervo de la Biblioteca Jurídica Virtual del Instituto de Investigaciones Jurídicas de la UNAM

Mirabeau a este propósito expresaba que:

...los poderes no pueden, sin duda, ser verificados separadamente, pues todos los diputados tienen un mismo derecho y un mismo interés a asegurarse de la legalidad de las diputaciones, puesto que ...cualquiera de los diputados puede influir directamente en la suerte general de la Nación: importa a todos, en consecuencia, saber si aquéllos que pretenden representarla están dotados de un título legítimo y esta certeza general no puede resultar jamás de la verificación por orden... ${ }^{55}$

A sabiendas de que se trataba de una cuestión de procedimiento, el Tercer Estado no estaba dispuesto a ceder, pues tenía conciencia que de la definición que se diera sobre este diferendo, dependía que hubiera o no Constitución. Para esta posición, como en muchas otras ocasiones más, iría a pesar la composición de la Asamblea: sobre seiscientos diputados del Tercer Estado, había más de trescientos juristas, notarios, abogados, procuradores, etcétera. ${ }^{56}$ Para justificar su pronunciamiento a favor de la verificación separada de los poderes, por su parte, la nobleza se fundaba en los "antiguos usos", supuestamente inmodificables, con lo que sugería la existencia de una tradición constitucional que no podía ser alterada.

Los argumentos de este orden los ilustró la intervención del Conde D'Antraigues, ante la nobleza ya constituida en Cámara separada:

Desde el primer día de vuestra reunión, habéis tomado por guía los usos de los anteriores Estados Generales, ¿Os corresponde cambiarlos? No, sin duda. Estos usos transmitidos por los precedentes Estados Generales eran vuestra ley. Vosotros podréis, una vez estando constituidos, deliberar si os convienen todavía, abolirlos, modificarlos, con el consentimiento de los tres órdenes; pero antes de estar constituidos, estáis sin poder para rechazar los

55 Furet, François y Halévi, Ran, La Monarchie..., cit., p. 118.

56 Chevallier, Jean-Jacques, op. cit., p. 19. 
Este libro forma parte del acervo de la Biblioteca Jurídica Virtual del Instituto de Investigaciones Jurídicas de la UNAM

usos y las leyes de los precedentes Estados Generales... Si alguna vez el olvido de las formas constitutivas hiciera perder el rumbo a los otros órdenes del Estado, es en éste que vivirá su recuerdo; esta Cámara será su santuario... Cuando uno de los órdenes del Estado es requerido para violar los usos y que, por esta primera gestión, se busca prepararlo para violar la más preciosa de vuestras leyes constitutivas, es entonces o nunca que es preciso restablecer sobre sus antiguas bases esas leyes tan reverenciadas por largo tiempo. ${ }^{57}$

Por su parte, los diputados de "los comunes" y sus aliados en el seno de la nobleza rechazaron el argumento porque - según ellos - los hechos no pueden tener fuerza de ley contra los derechos más ciertos de la nación. Aún el moderado Lally-Tollendal no vio sino ilusiones vanas en esa repetida invocación a tradiciones perdidas que abusivamente seguían siendo llamadas "Constitución". 58

No obstante, existía un argumento artificioso más difícil en desmontar, esgrimido por la nobleza, consistente en su pretensión de asimilar la separación de poderes con separación de órdenes. No es fácil interpretar esta posición del segundo orden si se tiene en cuenta que más de las dos terceras partes de sus cahiers de doleances se había pronunciado por una Constitución y que una amplia mayoría reconocía a los Estados Generales el ejercicio exclusivo del Poder Legislativo. Seguramente pesaba el miedo a perder la autonomía de que disfrutaba la nobleza si se le subsumía en una asamblea única junto a los otros órdenes estamentales, pero también pudo convencerlos la idea de erigirse en un instrumento "constitucional" de equilibrio de poderes, una vez establecidos en Cámara representativa de su orden. ${ }^{59}$ De esta forma, la discusión se centró en si debía haber una sola cámara

57 "Discours du comte D'Antraigues á la chambre de la nobless sur le caractère constitutif de la division des ordres (28 de mayo de 1789)", en Furet, François y Halévi, Ran, La Monarchie..., cit., p. 292.

58 Ibidem, p. 120.

59 Ibidem, p. 121. 
Este libro forma parte del acervo de la Biblioteca Jurídica Virtual del Instituto de Investigaciones Jurídicas de la UNAM

titular del Poder Legislativo o si debía la nobleza constituirse en una segunda cámara que moderara a la anterior.

De nueva cuenta, el Conde d'Antraigues, considerado entonces como el enemigo más temible del Tercer Estado, alertó con una premonición que el tiempo confirmaría “...si no existe más que una voluntad en el Estado; si el Poder Legislativo no reside más que en una sola asamblea, ¿cuál será el garante de ese Poder Legislativo frente a sí mismo? Así entonces, esta asamblea sola, al no conocer obstáculos invencibles en sus divisiones, podrá todo lo que quiera y será posible que, después de haber destruido la fuerza de los órdenes, anule también la sanción real y promulgue leyes por encima de la Constitución del Rey". ${ }^{60}$

Mirabeau le replicaría con furibunda diatriba en la que afirmó que la Constitución no estaba hecha para "equilibrar" los poderes "idea falsa y quimérica", sino para "subordinarlos". Ahora bien, "someter el poder soberano [es decir, a la nación] a ese pretendido equilibrio sería anularlo y preguntó si el efecto de una buena Constitución debe ser el de anular al poder soberano"; puesto que efectivamente es anular al poder soberano el oponerle "el de una corporación de nobles y de curas". ${ }^{61}$ Como la polémica siguiera y D’Antraigues replicara, Mirabeau la emprendió entonces contra Montesquieu mismo, al que consideraba la fuente del mal, el origen de esa curiosa jerarquía de poderes con un rey en la cúspide y dotado de potestad ilimitada, en seguida la nobleza y para terminar, en último rango, una nación avasallada por el despotismo y la aristocracia. Y se lanzó inmediatamente en un camino que predominaría en el pensamiento de la Revolución, "es menester enseñarles, dijo, que la autoridad del pueblo es superior al poder del Rey, que éste no es sino una concesión de aquélla y que, en consecuencia, debe estarle subordinado". ${ }^{62}$

$60 \quad$ Ibidem, pp. 293 у 294.

61 "Troisième lettre du Comte de Mirabeau á ses commetants", en Furet, François y Halévi, Ran, La Monarchie..., cit., pp. 123 y 124.

62 "Quatrième lettre du Comte de Mirabeau á ses commetants", en Furet, François y Halévi, Ran, La Monarchie..., cit., p. 124. 
Este libro forma parte del acervo de la Biblioteca Jurídica Virtual del Instituto de Investigaciones Jurídicas de la UNAM

Ante la amenaza que se cernía sobre el Tercer Estado de que el rey acordara la separación de las órdenes, Mirabeau se aplicó a extender los argumentos de deslegitimación que había lanzado contra la aristocracia, ahora contra la autoridad del rey, haciendo proclamar la superioridad del derecho nacional sobre el derecho de la corona. Con esta maniobra colocó en el corazón de esta disputa, la cuestión del fundamento de la legitimidad política. En este mismo afán, adelantaría un argumento que sería más tarde la doctrina adoptada por el constitucionalismo francés, a propósito de la autoridad encargada de verificar los poderes "...¿Es verdad que la Asamblea Nacional tenga necesidad de juez o de árbitro para la verificación de sus poderes? ¿Puede reconocer otro juez, otro árbitro que ella misma?". ${ }^{63} \mathrm{La}$ verificación de poderes, en efecto, era la primera operación que correspondía llevar a efecto a ese cuerpo colegiado y se sentó la tesis de que sólo a éste correspondía dicha facultad, dando con ello paso a un principio sostenido no sólo en las Constituciones francesas, sino en muchas otras.

El 10 de junio Sieyès haría una moción que sería vivamente aplaudida. Invitó a sus compañeros a "salir de una larga inacción”. Y se preguntó: “¿se puede [salir de la inacción] sin la verificación de poderes? ¿no es evidente, al contrario, que es imposible formarse en asamblea activa sin reconocer previamente a aquellos que deben componerla?". En consecuencia, propuso que la Asamblea hiciera por última vez una exhortación a los diputados de los otros dos órdenes para reunirse con el Tercer Estado en la sala de sesiones correspondiente, "para asistir, concurrir y someterse a la verificación de los poderes". ${ }^{64}$ Así, la moción fue aceptada.

Al principio no tuvo eco el llamado, pero a los pocos días, tímidamente al principio y, más decididamente después, se des-

\footnotetext{
63 Ibidem, pp. 125 y 126.
}

64 Sieyès, Emmanuel-Joseph, "Motion sur la verification des pouvoirs (10 de junio de 1789)", Orateurs de la Revolution Française (textos escogidos, presentados y anotados por Furet y Halévi), París, Gallimard, 1989, colección Biblioteca de las Pléyades, t. I: Les Constituants, pp. 999-1001. 
Este libro forma parte del acervo de la Biblioteca Jurídica Virtual del Instituto de Investigaciones Jurídicas de la UNAM

prendieron diputados del clero para sesionar conjuntamente. Realizada la verificación, la Asamblea se planteó: ¿qué es ahora?, ¿qué quiere ser en adelante? Con un fuerte debate de por medio, Sieyès propuso, no sin la oposición de Mirabeau, a que se llamara y constituyera "Asamblea Nacional".

Mirabeau expresaría su opinión, aderezada con un comentario vitriólico sobre Sieyès:

Es menester constituirnos, todos estamos de acuerdo en ello; pero ¿cómo? ¿bajo qué forma? ¿bajo qué denominación? ¿en Estados Generales? La palabra sería impropia; todos lo habéis sentido: supone tres órdenes, tres estados y ciertamente esos tres órdenes no están aquí... ¿La moción del señor Abate Sieyès os da raíces suficientemente profundas? ¿No es evidentemente una determinación primera, la cual tiene consecuencias que deben ser desarrolladas?... No toméis un nombre que asuste. Buscad uno que no se os pueda objetar; que, más suave y menos imponente en su plenitud, convenga a todos los tiempos, sea susceptible de todos los desarrollos que os permitirán los acontecimientos y pueda, si es necesario, servir de lanza como de ayuda a los derechos y a los principios nacionales. Tal es, a mi juicio, la fórmula siguiente: "Representantes del pueblo francés"... reconozco que la moción del señor Abate Sieyès es conforme al rigor de los principios, tal y como debe esperarse de un ciudadano filósofo. Pero, señores, no es siempre oportuno, no es siempre conveniente consultar únicamente al Derecho, sin conceder nada a las circunstancias. Hay una diferencia esencial entre el metafísico, quien en la meditación del gabinete, aprehende la verdad en su pureza enérgica y el hombre de Estado que está obligado a tener en cuenta antecedentes, dificultades, obstáculos; hay, digo, esta diferencia entre el instructor del pueblo y el administrador político, que no piensa más que "en lo que es" y el otro que se ocupa "de lo que puede ser". ${ }^{65}$

Parecería que Mirabeau trató infructuosamente de impedir el voto, pues previó sus consecuencias: a la larga, de ahí surgiría

65 "Premier discours de Mirabeau sur la denomination de l'Assamblee (15 de junio de 1789)", en Furet, François y Halévi, Ran, La Monarchie..., cit., pp. 299-304. 
Este libro forma parte del acervo de la Biblioteca Jurídica Virtual del Instituto de Investigaciones Jurídicas de la UNAM

la Revolución, misma que transferiría la titularidad de la soberanía del rey a la nación.

Finalmente, fue tomada la decisión el 17 de junio de 1789 . Del acta levantada de la sesión se puede destacar lo siguiente: hubo cinco mociones con propuestas sobre cuya lectura versó la deliberación, las de Sieyès, Mirabeau, Mounier, Legrand y Pison du Galand; la moción de Sieyès fue la aceptada por una mayoría de cuatrocientos noventa y un votos contra noventa. En consecuencia, la Asamblea determinó que:

La Asamblea deliberante, después de la verificación de poderes, reconoce que esta Asamblea ya está compuesta por los representantes enviados directamente por las noventa y seis centésimas, al menos, de la Nación... Los ausentes que han sido llamados no pueden impedir a los presentes ejercer a plenitud sus derechos, sobre todo cuando el ejercicio de esos derechos es un deber imperioso y presionante... Es además indispensable concluir que le pertenece y que no le pertenece sino a ella interpretar y presentar la voluntad general de la Nación; no puede existir entre el trono y esta Asamblea ningún veto, ningún poder negativo... La denominación de "Asamblea Nacional" es la única que conviene a la Asamblea en el estado actual de las cosas... porque la representación, siendo una e indivisible, ninguno de los diputados, en cualquier orden o clase que sea escogido, tiene el derecho de ejercer sus funciones separadamente de la presente Asamblea... La Asamblea vota a un llamado al Rey para hacerle parte de la deliberación acordada... ${ }^{66}$

Por lo que es obvio que ella retomaba la argumentación de los opúsculos de Sieyès y de su moción presentada días antes. Por otra parte, en un audaz gesto que ligaba al poder económico con el político la Asamblea decretó, como facultad propia, la aprobación de los impuestos. ${ }^{67}$

66 "Constitution de l'Assamblèe National", 17 de junio de 1789, ibidem, pp. 311 y 312.

67 Chevallier, Jean-Jacques, op. cit., p. 21. 
Este libro forma parte del acervo de la Biblioteca Jurídica Virtual del Instituto de Investigaciones Jurídicas de la UNAM

Se llevaba a cabo un acto de creación revolucionaria, pues nacía un nuevo poder independiente del rey y nacía una nueva soberanía, sin que la antigua la reconociera y, como este pronunciamiento implicaba su propia negación, no había más opción que combatir sin cuartel o ceder la plaza. Naturalmente la decisión del Tercer Estado causó fracturas en los otros dos: la mayoría del clero se pronunció por reunirse, y ochenta y cuatro votos de nobles liberales lo aceptaron también. Sin embargo, se enfrentaron a la resistencia de los obispos y a la de la mayoría de la nobleza. Pretendieron, entonces, buscar protección en Luis XVI y éste aceptó, pero sólo decidió sobre la forma de su arbitraje, ésta consistió en llevar a cabo el 23 de junio una sesión real en el seno de los Estados Generales, mientras tanto ordenó cerrar la sala de sesiones. Al encontrar cerrada la sala de Menus plaisirs los diputados se trasladaron a la famosa sala feu de Paume donde se llevaría a cabo el también célebre juramento solemne de los diputados de "no separarse jamás y de reunirse en cualquier lugar que las circunstancias lo exigieran hasta que la Constitución del reino fuera establecida y afianzada sobre fundamentos sólidos...". Todos los diputados, salvo uno, prestaron dicho juramento. ${ }^{68}$

$\mathrm{Al}$ interior del frente absolutista no existía una posición única. Necker, director de Finanzas y cabeza de las posturas liberales, propuso hacer ciertas concesiones que apostaban a la distensión, aunque el entorno más conservador del Rey se opuso y ganó la voluntad de éste. La sesión de los Estados Generales, con la presencia del rey daba comienzo en medio de signos inquietantes: la ausencia de Necker, y un fuerte dispositivo militar, etcétera.

El discurso del rey causó cierta decepción, pese a algunas concesiones hechas, como la de aceptar el principio consistente en que era a los Estados Generales a los que correspondía aprobar los impuestos y los empréstitos; la libertad individual y la de prensa; la descentralización administrativa y formuló, además, el deseo que los privilegiados aceptaran la igualdad fiscal.

68 Furet, François y Richet, Denis, La Revolution..., cit., pp. 76 y 77. 
Este libro forma parte del acervo de la Biblioteca Jurídica Virtual del Instituto de Investigaciones Jurídicas de la UNAM

Pero guardó silencio sobre la admisión de todos a las funciones públicas; rechazó explícitamente todo acuerdo sobre los futuros Estados Generales y, sobre todo, mantuvo expresamente las jerarquías tradicionales de la sociedad aristocrática.

Para el Tercer Estado aquello no era un arbitraje, sino una toma de partido, puesto que se aceptaba sólo lo que la aristocracia tenía a bien conceder. Por lo demás, la declaración del rey no sólo anulaba sus acuerdos del día 17, sino que bajo la amenaza velada de la disolución se les ordenaba formalmente a los diputados separarse y deliberar aparte. Una vez que el rey, la nobleza y los prelados abandonaron la sala, los diputados, conminados a salir, buscaban afanosamente las respuestas que explicaran las circunstancias y les dieran una salida. Bailly lanzó lo siguiente: "la Nación reunida no puede recibir órdenes". Sieyès invitó: "vosotros sois hoy lo que érais ayer. Deliberémos". Mirabeau desafió con "no abandonaremos nuestros lugares más que por la fuerza de las bayonetas". La audacia de estos llamados les alentó y se decidió persistir en los acuerdos tomados, decretándose la inviolabilidad de sus miembros.

Esta actitud desafiante tuvo sus efectos, ya que el 24 de junio la mayoría del clero se unió a la Asamblea y el 25 la resistencia de la nobleza se desmoronó al agregarse a la Asamblea cuarenta y siete de sus representantes, entre los cuales destacaban: Clermont-Tonnerre, La Rochefoucauld, Du Port y el Duque de Orleans. El rey no parecía tener ya otro camino que inclinarse ante los hechos e invitó a "su fiel clero" y a "su fiel nobleza" a reunirse con el Tercer Estado. ${ }^{69}$

Es hasta el 7 de julio que la Asamblea pudo elegir una comisión encargada de preparar la nueva Constitución. Se componía, en su mayoría, de diputados moderados. Estimaban que tenían por tarea poner por escrito, en un orden racional, a las antiguas instituciones de Francia y que no se trataba de modificar, sino

69 Ibidem, pp. 76-79. 
Este libro forma parte del acervo de la Biblioteca Jurídica Virtual del Instituto de Investigaciones Jurídicas de la UNAM

aquéllas que ya no fueran válidas. Por supuesto que no se trataba de derrocar a la monarquía.

Sólo como ejercicio de imaginación es válido pensar lo que hubiera pasado de haber sido Luis XVI consecuente con las anteriores medidas y de no haber tomado una serie de decisiones que engrosaban las filas de sus enemigos. En efecto, la Revolución victoriosa, la que acababa de erigir una nueva soberanía, no planteaba por lo menos no por el momento la incompatibilidad de la soberanía nacional con la del monarca. A distancia, la coexistencia de ambas parecería factible, pues la burguesía admitía el cogobierno con el rey y la nobleza. ${ }^{70}$ Pero, en una marcha inexorable hacia un destino que se miraba fatal, el rey despidió a Necker y a los ministros liberales de su gabinete e hizo concentrar tropas en un París ya exasperado por el hambre y el miedo, en lo que fue interpretado como una declaración de guerra. El llamado "complot aristocrático" hizo su labor en el imaginario social y todos conocemos el hecho emblemático de la Revolución: la toma, el 14 de julio de 1789, de esa legendaria prisión que concentraba todos los rencores sociales. Los hechos forzarían a Luis XVI, una vez más, a ceder: compareció ante la Asamblea a anunciar el retiro de las tropas, volvió a convocar a Necker y a sus colegas liberales al ministerio, y nombró a Bailly y a La Fayette, respectivamente, alcalde de París y comandante de la guardia nacional recién creada.

Paralelamente, en el campo se desataba una revuelta agraria, que en algunas regiones tomó tintes de guerra social y que puso en grave entredicho a la Revolución triunfante, pues si el Tercer Estado trataba de imponer orden, combatiendo la anarquía, el pillaje y el ataque a las propiedades, uniendo a la nueva milicia burguesa con las tropas realistas, se ponía a merced del rey. De otra forma, si trataba de montarse en la cresta de la ola y aprovechar a sus aliados, necesitaba radicalizarse, yendo adelante de sus reivindicaciones. Así, optó, al principio, por el primer camino.

\footnotetext{
$70 \quad$ Ibidem, p. 79.
} 
Este libro forma parte del acervo de la Biblioteca Jurídica Virtual del Instituto de Investigaciones Jurídicas de la UNAM

En efecto, el 4 de agosto, la ya reconocida Asamblea Nacional escuchó la propuesta de Target, diputado del Tercer Estado parisino, "la Asamblea Nacional, considerando todos los problemas y las violencias que afligen a las diversas provincias, extienden la alarma en los espíritus e infligen el daño más funesto a los derechos sagrados de la propiedad y la seguridad de las personas ... declara que todos los censos y prestaciones acostumbradas deben ser pagadas como en el pasado hasta que la asamblea haya ordenado lo contrario". ${ }^{71}$ Sin embargo, fue la otra opción la que ganaría.

Ciertamente el terreno estaba abonado, "los privilegios góticos" provocaban más que cualquier otra cosa, el rechazo unánime de la población y esta condena había sido recogida en un breve y contundente alegato, escrito por Sieyès, en el verano del 88 y no publicado sino hasta noviembre, en forma anónima. No obstante, sus argumentos ganaron la empatía de los lectores, de suerte que fueron publicadas dos ediciones más en pocos meses.

El hilo conductor de su alegato es el del principio rector de la sociedad moderna, basada en las relaciones de mercado: la igualdad de todos los hombres ante la ley, condición para que opere la relación de intercambio de mercancías. Empezó por fijar la naturaleza de los privilegios: “...todos los privilegios, sin distinción, tienen ciertamente por objeto «dispensar» de la ley o conceder un «derecho exclusivo» a alguna cosa que no esté prohibida por la ley...”. Se preguntó, enseguida, cuál es el objeto de la ley “... este, sin duda, es el de impedir que sea vulnerada la libertad o la propiedad". Con lo que, por su formulación negativa y la mención a los dos valores fundamentales del liberalismo, no dejó lugar a dudas de su adscripción ideológica. Afirma la existencia de una "ley-madre" de las que derivan todas las demás: "no hagas daño a tu prójimo". Todas las que pueden impedir que se cause daño a los demás, concluye, serán buenas y serán necesariamente malas las que no sirvan para ese fin.

71 Ibidem, pp. 80-87. 
Este libro forma parte del acervo de la Biblioteca Jurídica Virtual del Instituto de Investigaciones Jurídicas de la UNAM

En un párrafo, cuyas coincidencias con Locke son notables, estableció que:

...una larga servidumbre de las conciencias ha introducido los más deplorables prejuicios. El pueblo cree, casi de buena fe, que no tiene derecho más que a lo que está permitido por la ley. Parece ignorar que la libertad es anterior a toda sociedad, a todo legislador y que los hombres no se han asociado más que para poner sus derechos a cubierto de los atentados de los malos y para entregarse, al abrigo de esta seguridad, a un desarrollo más amplio, más enérgico y más fecundo en el goce de sus facultades morales y físicas. El legislador ha sido establecido no para conceder, sino para proteger nuestros derechos. Si a veces limita nuestra libertad, lo hace en virtud de aquellos de nuestros actos que resultan perjudiciales a la sociedad y, por tanto, la libertad civil se extiende a todo aquello que la ley no prohíbe.

Así, puso en claro que la sociedad y el Estado son creaciones de la voluntad de los hombres, que se asociaron para poner a salvo libertades y derechos anteriores a la sociedad, al Estado y a la ley. Asimismo, formuló el principio jurídico, hoy universalmente aceptado, según el cual el individuo privado puede hacer todo lo que no esté prohibido por la ley, a diferencia de gobernantes y funcionarios que sólo pueden llevar a cabo lo que les está expresamente ordenado por ésta, regla que rige al derecho público y que es garantía de libertad y de límite a la actuación de los gobernantes. A la ayuda de los anteriores conceptos ya pudo juzgar a los privilegios:

Los que tienen por objeto la dispensa de la ley no pueden sostenerse porque toda ley, como ya hemos indicado, dice directa o indirectamente "no hagas daño a tu prójimo", y ellos supondrían algo así como decir a los privilegiados: "se os permite hacer daño al prójimo". No hay poder al que le sea dado hacer tal concesión. Si la ley es buena debe obligar a todo el mundo y si es mala es preciso destruirla porque supone un atentado contra la libertad... Igualmente, no se puede conceder a una persona el derecho ex- 
Este libro forma parte del acervo de la Biblioteca Jurídica Virtual del Instituto de Investigaciones Jurídicas de la UNAM

clusivo a alguna cosa que no esté prohibida por la ley, puesto que supondría tanto como arrebatar a los ciudadanos una porción de su libertad. Todo lo que no está prohibido por la ley - como lo hemos indicado - es del dominio de la libertad civil y pertenece a todo el mundo... todos los privilegios son, pues, por su propia naturaleza, impuestos odiosos y están en contradicción con el fin supremo de toda sociedad política... ${ }^{72}$

Reveló el significado de la jerarquización entre los individuos que exige la moderna sociedad. En adelante, la que se verá honrada y reconocida será la función y no la persona, se trastocaba, así, la aristocracia de las personas por la de las funciones:

No confundamos, en ningún caso, la superioridad absurda y quimérica obra de los privilegios, con la superioridad legal entre gobernantes y gobernados. Esta es real y necesaria... la única jerarquía necesaria, ya lo hemos dicho, se establece entre los agentes de la soberanía; es ahí donde es precisa una graduación de poderes, donde se encuentran unas verdaderas relaciones de inferior a superior... fuera de ella no hay más que ciudadanos iguales ante la ley, todos dependientes no los unos de los otros, sino de la autoridad que les protege, que les juzga, que les prohíbe, etc. Descubría ante nuestros ojos, finalmente, porqué la igualdad de los hombres ante la ley es condición para el funcionamiento de la sociedad moderna, la sociedad de mercado: ..."un ciudadano, quien quiera que sea, que no es mandatario de la autoridad, no ha de hacer otra cosa que mejorar su suerte, gozar de sus derechos sin pedir los derechos de los otros, es decir, sin faltar a la ley. Todas las relaciones de ciudadano a ciudadano son relaciones libres. Uno da su tiempo o su mercancía, otro entrega, a cambio, su dinero; en ningún caso hay subordinación, sino cambio continuo." 73

72 Sieyès, Emmanuel-Joseph, "Ensayo sobre los privilegios", en Pantoja Morán, David (comp.), Escritos políticos de Sieyès, México, Fondo de Cultura Económica, 1993, pp. 115 y 116.

73 Ibidem, pp. 122 y 123. 
Este libro forma parte del acervo de la Biblioteca Jurídica Virtual del Instituto de Investigaciones Jurídicas de la UNAM

En la noche anterior a la sesión ya un grupo de diputados había convenido en hacer ciertas concesiones que parecían inevitables y que permitirían preservar la alianza entre los tres estamentos. Una voz importante que se dejó oír, después de la intervención de Target fue la de uno de los nobles más ricos del reino, el duque D'Aiguillon, quien comenzó por justificar la violencia popular, que trataba de sacudirse un yugo de siglos y demandó no privar a los nobles pura y simplemente de sus derechos feudales, sino de concederles una justa indemnización por ellos; para concluir en una moción elaborada que proponía la igualdad fiscal, la abolición pura y simple de las prestaciones y servidumbres personales y la reducción de otros derechos feudales, con una tasa de interés. ${ }^{74}$

Las propuestas fueron acogidas con entusiasmo, pues detrás de la solución política estaba el fino cálculo financiero que reconvertía los antiguos derechos feudales en dinero burgués y mantenía el pago de los intereses hasta que el capital no hubiera sido pagado. Así, los nobles salvaban lo esencial y los propietarios del Tercer Estado ganaban todo, al equipararse sus tierras con las propiedades nobiliarias. Todos entendieron muy bien que a través de sus acuerdos, dejaban atrás el principio que regía al régimen feudal y lo aceptaron, con tal entusiasmo que queriendo asociar al Rey al advenimiento de la nueva sociedad, le declararon "restaurador de la libertad francesa". ${ }^{75}$

Sin embargo, esta unanimidad exultante no iría a durar, pues, en cuanto se trató de materializar en decretos lo acordado en la sesión histórica del 4 de agosto, se trocó en debate áspero que se prolongó hasta el día 11. Los actores principales del enfrentamiento, a propósito de los derechos señoriales no sometidos a redención y de la abolición del diezmo irían a ser dos

74 D'Aiguillon, "Motion sur les privilèges particuliers et sur les droits féudaux et seigneuriaux", Orateurs de la Revolution Française (textos escogidos, presentados y anotados por Furet y Halévi), París, Gallimard, 1989, colección Biblioteca de las Pléyades, t. I: Les Constituants, pp. 3 y 5.

75 Furet, François y Richet, Denis, La Revolution..., cit., pp. 88 y 89. 
Este libro forma parte del acervo de la Biblioteca Jurídica Virtual del Instituto de Investigaciones Jurídicas de la UNAM

figuras señeras de la Asamblea Constituyente quienes, por cierto, se abstuvieron de participar en la memorable sesión del día 4: Mirabeau y Sieyès.

Sieyès expresó sus puntos de vista en dos ensayos que serían publicados por la Asamblea. En el primer ensayo (donde expresó su rechazo al cambio de opinión de la Asamblea, pues el 4 de agosto había acordado que el diezmo sería abolido con indemnización y después decretó que lo sería sin ésta) su argumentación fue más de circunstancia, atacó la injusticia que entrañaba declarar abolido el diezmo sin indemnización, porque iba a beneficiar a los propietarios más ricos. Aunque admitía su carácter nocivo tal como estaba concebido, desechaba la idea de que el diezmo fuera equiparado al impuesto, ya que en su origen: "fue primero una donación libre y voluntaria de algunos propietarios. Poco a poco, el ascendiente de las ideas religiosas lo extendió casi por doquier; terminó siendo una verdadera cesión... de tal modo, es preciso considerar al diezmo como una carga o un censo impuesto a la tierra, no por la Nación, como se pretende sin ningún género de prueba, sino por el propietario mismo, que sin duda era libre de dar su bien en las condiciones que mejor le pareciesen". Concluyó diciendo que el diezmo no debía compararse con un impuesto:

...sino como un verdadero censo impuesto a sus propios bienes por el dueño. El impuesto se acepta tan solo por algún tiempo; se le puede revocar a voluntad de los representantes de la Nación, mientras que el diezmo ha sido cedido a perpetuidad por aquellos mismos, precisamente, que hubieren podido deshacerse de él... por consiguiente no debe ser suprimido en beneficio de los capitales actuales, que además saben de sobra que jamás compraron el diezmo y que, por ello, no podría pertenecerles... no obstante, siendo colocado el diezmo, con mucha razón, en la clase de las propiedades legítimas de verdad, pero nocivas para la cosa pública, es preciso extinguirla, como se extingue esta clase de propiedades, es decir, pagando una indemnización... Si el diezmo eclesiástico se suprime sin indemnización, como os ha sido pro- 
Este libro forma parte del acervo de la Biblioteca Jurídica Virtual del Instituto de Investigaciones Jurídicas de la UNAM

puesto ¿qué se seguirá de ello? ¿El diezmo se quedará en manos del que lo debía, en vez de ir a parar a las manos de aquel a quien se le debía?... No hay una sola tierra que no haya sido vendida y vuelta a vender desde que se estableció el diezmo... el diezmo no pertenece a ninguno de los propietarios que lo pagaban hasta ahora; lo repito, ninguno ha comprado, ninguno ha adquirido en propiedad esta parte de la renta de su bien... ${ }^{76}$

En su segundo alegato se remontó a principios más generales. A propósito de la polémica coyuntural sobre la abolición del diezmo y ya pesando en su ánimo el presagio de la expropiación de los bienes del clero, medida que sería tomada más tarde, elaboró un argumento inteligente en defensa de la propiedad frente a los poderes públicos. Su argumentación, en esencia, consistió en afirmar que el servicio eclesiástico era un servicio público y que bajo este título existía legítimamente. Que los bienes donados al clero lo habían sido bajo determinadas condiciones y obligaciones, y mientras que éste no se rehusara a cumplirlas, no se le podía despojar de aquéllos.

Por lo que rebatió el argumento de que la nación fuera propietaria de los bienes del clero porque éstos sirvieran como salario para los eclesiásticos:

La idea más sencilla, dijo, en lo que respecta a la propiedad, es la de que un bien pertenece a aquél a quien le ha sido dado, o que lo ha adquirido. Los bienes eclesiásticos no han sido dados a la Nación, sino al clero... mientras exista, es propietario; ¿porqué? Porque en su calidad de cuerpo moral está habilitado para poseer, y porque, en efecto, grandes bienes le han sido dados en propiedad... Por consiguiente, el clero es verdaderamente propietario... Mientras el cuerpo del clero no sea suprimido, es el único propietario de sus bienes...

76 Sieyès, Emmanuel-Joseph, "Opinión del señor abate Sieyès sobre el decreto del 4 relativo a los diezmos, pronunciada el 10 de agosto en la sesión vespertina”, en Pantoja Morán, David (comp.), Escritos políticos de Sieyès, México, Fondo de Cultura Económica, 1993, pp. 201-204. 
Este libro forma parte del acervo de la Biblioteca Jurídica Virtual del Instituto de Investigaciones Jurídicas de la UNAM

Agregó, entonces, su alegato a favor de la propiedad "la Nación misma, aunque sea el supremo legislador, no puede despojarme ni de mi casa ni de mi crédito. Remontándonos hasta los principios encontramos que la garantía de la propiedad es el fin de toda legislación. ¿Cómo concebir que el legislador me la pueda quitar? No existe sino para protegerla..."77 Es advertible en este argumento la tradición lockiana del derecho natural, la que coloca a la propiedad en la base del orden social como el primer derecho fundamental del hombre y para cuya protección se habría constituido la sociedad.

Por su parte, Mirabeau empezó por afirmar que "el diezmo no es una propiedad"; pues por propiedad no puede entenderse más que aquélla cuyo fondo puede enajenarse y "el clero jamás lo ha podido". Así:

los diezmos no han sido jamás para el clero sino disfrutes anuales de simples posesiones revocables por la voluntad del soberano... Hay más, el diezmo no es ni siquiera una posesión, como se ha dicho, es una contribución destinada a esa parte del servicio público que concierne a los ministros de los altares; es el subsidio con el cual la Nación fija un salario a los oficiales de la moral y de la instrucción... Es justo y conveniente que [los oficiales de la moral y de la instrucción] sean dotados de una manera conforme a la dignidad de su ministerio y a la importancia de sus funciones, pero es necesario que no puedan reclamar un modo pernicioso de contribución como [si fuera] una propiedad... No sé porqué se les disputaría que el diezmo sea una institución nacional; lo es en efecto y es a causa de ello mismo que la Nación tiene el derecho de revocarlo y de substituirlo por otra institución... La Nación abole los diezmos porque son un medio oneroso de pagar

77 Sieyès, Emmanuel-Joseph, "Breves observaciones sobre los bienes eclesiásticos", ibidem, pp. 190 y 191. Para una historia detallada de los avatares de esta discusión sobre la abolición del diezmo, véase Zapperi, Roberto, "Sieyès et l'abolition de la féodalité", Annales historiques de la Revolution Francaise, núm. 44, 1972, pp. 321 y ss. 
Este libro forma parte del acervo de la Biblioteca Jurídica Virtual del Instituto de Investigaciones Jurídicas de la UNAM

la parte del servicio público al cual están destinados y porque es fácil reemplazarlos de una manera menos dispendiosa y legal... ${ }^{78}$

La victoria de esta tesis haría al clero el primer perdedor en la liquidación del régimen feudal.

Finalmente, el 11 de agosto de 1789 sería aprobado el decreto relativo a la abolición de los privilegios, producto de la sesión del 4 de agosto. Integrado por diez artículos, empezaba de una manera impactante:

La Asamblea Nacional destruye enteramente el régimen feudal. Decreta que en los derechos y deberes, tanto feudales como censuales, aquéllos que corresponden a las manos muertas real o personal y a la servidumbre personal y aquellos que los representan sean abolidos sin indemnización; todos los otros son declarados redimibles... Todas las justicias señoriales son abolidas, sin ninguna indemnización... Los diezmos de cualquier naturaleza y las rentas que hacen las veces, bajo cualquier denominación que sean conocidas y percibidas... "poseídas por cuerpos seculares y regulares"... son abolidas. Todas las rentas territoriales perpetúas, sea en especie, sea en dinero, de cualquier naturaleza que sean, cualquiera que sea su origen, a cualquier persona que le sean debidas... serán redimibles... La venalidad de los oficios de judicatura y de municipalidad está suprimida desde este instante... Los privilegios pecuniarios personales o reales, en materia de subsidios son abolidos para siempre... Todos los privilegios particulares de las provincias, países, cantones, ciudades y comunidades de habitantes, sean pecuniarias, sean de cualquier otra naturaleza son abolidas sin retorno y permanecerán confundidas en el derecho común de todos los franceses... todos los ciudadanos sin distinción de nacimiento, podrán ser admitidos a todos los empleos, dignidades eclesiásticas civiles y militares... La Asamblea

78 Mirabeau, "Discours sur la suppresion ou le rachat des dîmes (10 de agosto de 1789)", Orateurs de la Revolution Française (textos escogidos, presentados y anotados por Furet y Halévi), París, Gallimard, 1989, colección Biblioteca de las Pléyades, t. I: Les Constituants, pp. 660 y 661. 
Este libro forma parte del acervo de la Biblioteca Jurídica Virtual del Instituto de Investigaciones Jurídicas de la UNAM

Nacional proclama solemnemente al Rey Luis XVI "restaurador de la libertad francesa". ${ }^{79}$

Los logros de la noche del 4 de agosto son de una importancia extrema. La demolición de la estructura social que albergaba al Antiguo Régimen implicó que las distinciones, los privilegios, los particularismos, en una palabra, los órdenes estamentales fueran abolidos. En adelante, todos los franceses podrían poseer los mismos derechos y deberes, acceder a los mismos empleos y dignidades, y pagarían los mismos impuestos. Al hacer tabla rasa con las desigualdades y hacer posible una sociedad de individuos iguales ante la ley, se franqueaba cabalmente el paso a una nación. Al liquidar a la aristocracia se ponían las bases de un nuevo contrato social.

Los efectos de esa noche irían a plasmarse más tarde en el preámbulo de la Constitución de 3 de septiembre de 1791. Empleando una bella imagen, Waline afirma que en las frases de ese preámbulo parece escucharse el viento que arranca de raíz los fresnos. Existe, en efecto, un refrán monótono que se repite con fuerza: "no existe más".

No existe más ni nobleza, ni pares, ni distinciones hereditarias, ni distinciones de órdenes, ni régimen feudal, ni justicias patrimoniales, ni ninguno de los títulos, dominaciones y prerrogativas que de ellas derivaban, ni ningún orden de caballería, ni ninguna de las corporaciones o decoraciones por las cuales exigía pruebas de nobleza, o que supusieran distinciones de nacimiento, ni ninguna otra superioridad que aquella de los funcionarios públicos en el ejercicio de sus funciones. No existe más ni venalidad, ni herencia de ningún oficio público. No existe más para ninguna parte de la Nación, ni para ningún individuo ningún privilegio, ni excepción al derecho común de todos los franceses... ${ }^{80}$

79 "Décret relatif á la abolition des privileges (11 de agosto de 1789)", en Furet, François y Halévi, Ran, La Monarchie..., cit., pp. 342-344.

80 Chevallier, Jean-Jacques, op. cit., p. 26. 
Este libro forma parte del acervo de la Biblioteca Jurídica Virtual del Instituto de Investigaciones Jurídicas de la UNAM

Abolir las consecuencias de un sistema social fincado en órdenes estamentales privilegiadas tocaba en partes vitales también a la estructura social, ya que afectaba al régimen de propiedad. Se trataba, en efecto, de abolir el sistema sucesorio fundado en dos privilegios: el de la masculinidad y el del mayorazgo. Con sus decisiones, la Constituyente puso en movimiento lo que Tocqueville bautizó con una expresión famosa: "la máquina de hacer picadillo el suelo", no refiriéndose a la pulverización de la propiedad territorial campesina, que había sido anterior, sino a la división extrema que se podía llevar a cabo sobre la tierra poseída por la nobleza, que representaba una cuarta parte de la superficie nacional. ${ }^{81}$

En otros términos, no sólo se trataba de cambios en el ámbito político, sino en "la constitución social", puesto que, por técnico que pareciera el régimen sucesorio, en él se plasmaba "el estado social". La Constituyente entendió muy bien que sus decisiones no sólo iban dirigidas a la política pura, sino a la transformación de la sociedad, puesto que se trastocaba el espíritu del derecho civil y enderezaron sus acciones hacia esa rama del derecho que pudiera ser considerada constitucional. Es así que, más tarde también, en el título primero dedicado a "las disposiciones fundamentales garantizadas por la Constitución” de la Constitución de 1791, inscribieron una disposición que implicaba un compromiso: "se hará código de leyes civiles comunes a todo el reino", ${ }^{82}$

En la interpretación de estos acontecimientos chocan dos posturas. Está la posición de quienes - al advertir que la Asamblea transformó en "buen dinero burgués", si no todos los derechos feudales, al menos una parte de ellos - sólo ven en la noche del 4 de agosto a la desigualdad burguesa substituyendo a la desigualdad nobiliaria feudal. Pero están quienes piensan que esa noche en que fue abolida la sociedad aristocrática hubo algo más esencial consistente en la desaparición de la dependencia jerárquica de los hombres, el nacimiento del individuo moderno

\footnotetext{
81 Ibidem, p. 27.

82 Ibidem, p. 28.
} 
Este libro forma parte del acervo de la Biblioteca Jurídica Virtual del Instituto de Investigaciones Jurídicas de la UNAM

y la idea de la aplicación universal de la ley a todos los hombres, independientemente de su condición. Así, nacieron los principios bajo los cuales aún vivimos: el individuo libre e igual es el centro de un nuevo mundo social, atomizado en millones de microsoberanías. Pero esta figura de pulverización es ratificada en la reunión de todos los ciudadanos, merced a la obediencia común a una ley de la que son autores y, por todo ello, se funda la nación como indivisible. ${ }^{83}$

Con todo - según Soboul, que sostiene la primera postura - habría que esperar a la labor de la Asamblea Legislativa y a la de la Convención para que el resultado del decreto se llevara hasta sus últimas consecuencias. ${ }^{84}$ En esa misma jornada algunas horas antes del debate, a propuesta de Barnave, la Asamblea decidió que debía votarse una "gran carta liberadora", a la que el propio Barnave había denominado "catecismo nacional"; en esa madrugada se decretó que la Constitución debería ir precedida de una declaración de derechos. ${ }^{85}$

\section{LA DEGLARAGión De los Derechos DEL Hombre Y DEL GiUdAdANO}

El tema de los derechos individuales ya estaba presente en la agenda de la Asamblea desde julio, pero los puntos de vista sobre la necesidad de una declaración estaban muy lejos de la unanimidad y sobre ello se debatió. Paralelamente, se recibieron diversos proyectos de declaración de Mounier, La Fayette, Lally-Tollendal, Servan, Sieyès y Clermont-Tonerre. En los primeros días de agosto se expresaron algunas aprensiones por parte de los moderados, temerosos de los desórdenes que habían estallado aquí y allá.

Uno de ellos, Malouet - en una reflexión que anuncia las observaciones agudas de Tocqueville en la democracia en Amé-

83 Furet, François y Halévi, Ran, La Monarchie..., cit., p. 176.

84 Soboul, A., op. cit., pp. 170-172.

85 Furet, François y Richet, Denis, La Revolution..., cit., p. 90. 
Este libro forma parte del acervo de la Biblioteca Jurídica Virtual del Instituto de Investigaciones Jurídicas de la UNAM

rica - a más de exponer una visión restrictiva de la Declaración deslizó una crítica a los proyectos presentados:

¿Convertiremos en acto legislativo esta exposición metafísica o presentaremos los principios con su modificación en la constitución que haremos? Sé que los americanos no tomaron esta precaución; tomaron al hombre en el seno de la naturaleza y lo presentan al universo en su soberanía primitiva. Pero la sociedad americana nuevamente formada está compuesta en totalidad de propietarios ya acostumbrados a la igualdad, ajenos al lujo como a la indigencia, conociendo apenas el yugo de los impuestos, de los prejuicios que nos dominan, no habiendo encontrado sobre la tierra que cultivan ninguna traza de feudalidad. Tales hombres estaban, sin duda, preparados para recibir la libertad con toda su energía: pues sus gustos, sus costumbres, su posición les convocaba a la democracia. Pero nosotros, señores, tenemos por conciudadanos una multitud inmensa de hombres sin propiedades, que esperan, antes que otra cosa, su subsistencia de un trabajo seguro, de una policía exacta, de una protección continua... No se crea, sin duda, que concluyo que esta clase de conciudadanos no tenga un derecho igual a la libertad... Creo, señores, que es necesario, en un gran imperio, que los hombres colocados por la suerte en una condición dependiente, vean más bien los límites justos que la extensión de la libertad natural... ${ }^{86}$

Crénière - diputado del Tercer Estado por la circunscripción de Vendôme - por su parte, afirmó:

Los franceses piden, los franceses quieren una constitución libre; pero antes de hacer una constitución es necesario determinar el sentido que hay que dar a esta palabra... me parece que la constitución de un pueblo no es una ley, ni un código de leyes, llamadas impropiamente constitucionales, pues el establecimiento de una ley o de un código de leyes supone necesariamente algo anterior:

86 Malouet, "Sur les dangers d'une declaration des droits de l'homme (1 de agosto de 1789)", en Furet, François y Halévi, Ran, La Monarchie Republicaine, París, Fallard, 1996, pp. 336 y 337. 
Este libro forma parte del acervo de la Biblioteca Jurídica Virtual del Instituto de Investigaciones Jurídicas de la UNAM

es necesario que un pueblo exista antes de actuar, que sea constituido antes de organizarse, que los hombres devengan ciudadanos por un pacto, antes de devenir súbditos por el establecimiento de la ley... El objeto de una constitución debe ser el de asegurar únicamente los derechos individuales, cuya reunión forma los derechos de todos, en tanto que las instituciones no deben tender sino a subordinar los intereses particulares al interés general... Me parece, en fin, que la constitución de un pueblo no puede ser un contrato entre ese pueblo y su jefe... ¿Qué es entonces la constitución de un pueblo? ...El hombre en estado de naturaleza no es libre ni esclavo; es independiente, ejerce sus facultades como le place, sin otra regla que su voluntad, sin otra ley que la medida de sus fuerzas; en una palabra, no tiene ni derechos que ejercer, ni deberes que cumplir... El hombre en sociedad tiene derechos naturales e imprescriptibles; tal es el axioma de la razón: los ciudadanos que los ejercen forman un pueblo; los súbditos que no los ejercen no son sino un tropel de hombres encadenados o engañados. Es el establecimiento de esos derechos naturales e imprescriptibles, anteriores a las leyes que no establecen sino derechos positivos o relativos, a lo que llamo constitución de un pueblo... ${ }^{87}$

Una opinión que merece recogerse desde ahora, porque su idea central si bien no fue acogida en lo inmediato, reapareció en la Declaración de los Derechos y Deberes del Hombre y del Ciudadano del 5 Fructidor, año III (22 de agosto de 1795), fue la del abate Grégoire. Se puede condensar así dicha opinión:

...¿¿Esta declaración [la que la Asamblea decretó sirviera de preámbulo de la Constitución] contendrá también deberes? Tal es la cuestión discutida en este momento y sobre la que voy a exponer mi opinión... Los deberes no derivan de los derechos, como se acaba de sostener. Son correlativos y marchan sobre líneas paralelas. Es imposible concebir derechos activos, sin derechos pasivos y estos son los deberes... La constitución que voso-

87 Crénière, Jean-Baptiste, "Sur la nécessité de précéder la constitution d'une Declaration de Droits de l'Homme (1 de agosto de 1789)", ibidem, pp. 331-333. 
Este libro forma parte del acervo de la Biblioteca Jurídica Virtual del Instituto de Investigaciones Jurídicas de la UNAM

tros váis a hacer será una consecuencia de los deberes como de los derechos. La declaración, que será el preámbulo de ésta, debe, en consecuencia, plantear los fundamentos de unos y otros... En general, el hombre está más inclinado a usar de sus derechos que a cumplir sus deberes. En el primer caso, basta ceder a la corriente y, en el segundo, es necesario nadar penosamente en contra. El hombre no es virtuoso más que con esfuerzo... Estableced el contrapeso de los deberes y de los derechos; que sepa no sólo lo que quiere, sino además lo que debe; mostradle no sólo el círculo que puede recorrer, sino además la barrera que no puede franquear... 88

Ante el enorme flujo de proyectos y los puntos de vista irreconciliables, que de ellos se desprendían, los métodos habituales de trabajo parecían inoperantes. Así, se designaron sucesivamente, el 7 de julio, una comisión encargada de redactar la Constitución, formada por treinta comités o grupos; el 14 de julio, otra comisión redactora de la Constitución, ésta sólo compuesta de ocho miembros: Mounier, Talleyrand-Perigord, Sieyès, Clermont-Tonerre, Lally-Tollendal, Champion De Cicé, Le Chapelier y Bergasse, y el 12 de agosto, otra comisión más reducida compuesta por Demeunier, Mirabeau, La Luzerne, Redon y Tronchet. ${ }^{89}$

En nombre de la comisión nombrada para elaborar la declaración, Mirabeau expuso las dificultades de dicha tarea, por cuanto que estaba destinada a "un cuerpo político viejo y casi caduco". Además era difícil porque iba a servir de preámbulo a una Constitución que aún no se conocía. Las dificultades crecían — según el expositor - porque se había tenido que elaborar en tres días, a partir de veinte proyectos de declaración,

88 Gregoire, Henri-Baptiste, "Sur la nécessité de parler des devoirs dans la Declaration des Droits de l'Homme et du citoyen (sesión del 12 de agosto de 1789, pero ciertamente pronunciado el 4 del mismo mes)", Les Declarations de Droits de l'Homme de 1789, París, Payot, 1992, pp. 217 y 218.

89 Cfr. Fauré, Christine, "Presentation", Les Declarations de Droits de l'Homme de 1789, París, Payot, 1992, p.15. 
Este libro forma parte del acervo de la Biblioteca Jurídica Virtual del Instituto de Investigaciones Jurídicas de la UNAM

proyectos que "dignos de estima cada uno en su género, pero concebidos sobre planos diversos" y, por lo mismo, difíciles de fundir en un todo del que pudiera extraerse un resultado útil. Concluyó haciendo hincapié en el esfuerzo que había hecho la comisión por alejarse de las deducciones filosóficas y acercarse a la experiencia de todos los días y a los razonamientos simples que los hechos concitaban. ${ }^{90} \mathrm{Su}$ exposición suscitó vivas objeciones: el abate Gregoire solicitó que se invocara en el preámbulo la existencia de Dios; el pastor Rabaut Saint-Etienne y el duque de Lévis-Mirepoix encontraban confuso el texto.

En una segunda intervención, al día siguiente, Mirabeau hizo una vehemente y controvertida defensa del proyecto de la comisión que presidía y se lanzó contra la idea de redactar colectivamente: "de todas las cosas humanas, solo conozco una en que el despotismo no sólo sea bueno, sino necesario; es la redacción: y esas palabras comités y redacción aúllan de terror al verse acopladas". ${ }^{91}$

Ansiosos por las demoras ocasionadas y porque el propio Mirabeau proponía posponer la redacción de la Declaración, después de la Constitución, se decidió redactarla y votarla en asamblea general, artículo por artículo, sirviéndose de un proyecto como hilo conductor. Así, no deja de sorprender que en medio de circunstancias tan adversas, el texto hubiera tenido el éxito histórico que hoy conocemos.

El asunto de cuántos proyectos fueron los presentados ha sido motivo de controversia. Si Jellinek afirmó que fueron veintiuno, otros redujeron la lista a quince y, ya más recientemente, Gauchet ha identificado treinta y seis proyectos redactados por los propios constituyentes y once por autores externos. ${ }^{92}$

90 Mirabeau, "Premier discours sur la Declaration des Droits de l'Homme (17 de agosto de 1789)", Orateurs de la Revolution Francaise (textos escogidos, presentados y anotados por Furet y Halévi), París, Gallimard, 1989, colección Biblioteca de las Pléyades, t. I: Les Constituants, pp. 661 y 662.

91 Mirabeau, "Second discours sur la Declaration des Droits de l'Homme (18 de agosto de 1789)", ibidem, pp. 667-674.

92 Fauré, Christine, op. cit., p. 18. 
Este libro forma parte del acervo de la Biblioteca Jurídica Virtual del Instituto de Investigaciones Jurídicas de la UNAM

Debe consignarse que la mayor parte de los proyectos fue obra individual y sólo tres colectiva, éstos son: el presentado el 28 de julio por Mounier a nombre de la Comisión de la Constitución, el presentado el 17 de agosto por Mirabeau a nombre de la Comisión de los Cinco y el de la Comisión Sexta, por Champion de Cicé. ${ }^{93}$

La discusión se retomó el 12 de agosto y, entre los diversos proyectos presentados, se escogió para servir de base de la discusión el presentado por la Comisión Sexta, presidida por el arzobispo de Bourdeaux, Champion de Cicé. Resumido, reformado y radicalizado por un largo debate, que duró siete días, iría a ser la célebre Declaración de los Derechos del Hombre y del Ciudadano del 26 de agosto de 1789.

Fue la cuestión religiosa la que dio lugar a las controversias más vivas. Colocar o no a la Declaración bajo la invocación de Dios era el tema a debate, pues el proyecto hablaba del "legislador supremo del universo". Finalmente fue puesta "bajo los auspicios del Ser Supremo", con lo que se calculó se daría satisfacción a la mayoría de la población católica francesa y no se ofendía a aquéllos que profesaban otra religión. Sin embargo, los miembros del clero, que representaban la cuarta parte de la Asamblea, hubieran deseado que la Declaración reconociera a la católica como religión de Estado, por lo que Mirabeau señaló que "la libertad más ilimitada de religión es, a mis ojos, un derecho tan sagrado que la palabra tolerancia, que quisiera expresarla, me parece de algún modo tiránica ella misma, ya que la existencia de la autoridad que tiene el poder de tolerar atenta a la libertad de pensar, por lo mismo que tolera y, así, podría no tolerar...". ${ }^{94}$

Si con el decreto de abolición de la feudalidad, la Revolución llevaba a cabo una labor destructiva, con la Declaración de De-

93 Ibidem, p. 19.

94 Godechot, Jacques, "Introduction", Les constitutions de la France depuis 1789, París, Garnier-Flammarion, 1970, p. 24. 
Este libro forma parte del acervo de la Biblioteca Jurídica Virtual del Instituto de Investigaciones Jurídicas de la UNAM

rechos iría a empezar a construir el fundamento de un convivir en comunidad nuevo, por la enunciación de los derechos que cada individuo aportaba al entrar en sociedad y que ésta, en contrapartida, debía proteger y garantizar.

Mucho se ha debatido sobre la paternidad en la concepción de una declaración de derechos, cuando se advierte que los norteamericanos antecedieron a los franceses con algunos años en la emisión de ésta. ${ }^{95}$ Pero uno se puede preguntar si se trata en aquel caso de un acto fundacional, como lo fue el francés. En efecto, los textos de las antiguas colonias inglesas no rompieron frontalmente con el estado social anterior. No afirmaron derechos que fueran desconocidos para las comunidades de emigrantes que constituyeron la unión estadounidense. Declararon, al contrario, derechos vividos como fundamentales por los colonos desde su llegada a esa tierra virgen, donde formaron una sociedad basada en la adhesión voluntaria. En cambio, los franceses fraguaron un derecho natural de nuevo cuño. ${ }^{96} \mathrm{~A}$ diferencia de los norteamericanos que no tenían que derruir una sociedad fundada en las jerarquías de nacimiento, destruyeron jurídicamente el tejido social tradicional y se afanaron en reconstituir al cuerpo político, a partir de individuos iguales ante la ley. ${ }^{97}$

A petición de la comisión redactora de la Constitución de la Asamblea, Sieyès había presentado un documento preparatorio para la discusión parlamentaria. Este texto ejerció una influencia profunda sobre los debates, aunque su formulación no hubiera

95 Boutmy, Emile, "La Déclaration des droits de l'homme et du citoyen et M. Jellinek", Annales des Sciences Politiques, julio de 1902, t. XVII, pp. 415-443. La polémica célebre entre Jellinek y Boutmy está espléndidamente reseñada en Posada, Adolfo, "Estudio preliminar", en Jellinek, J., La Declaración de los Derechos del Hombre y del Ciudadano, Madrid, Librería General de Victoriano Suárez, 1908.

96 Cfr. Habermas, Jürgen, Derecho natural y Revolución, Buenos Aires, Ed. Sur, 1966, pp. 68 y 69. Para un recuento histórico del concepto de derecho natural véase el trabajo espléndido de Strauss, Leo, Droit naturel et Histoire, París, Flammarion, 1986, y Jouffroy, Theodoré, Cours de droit naturel, París, Fayard, 1988.

97 Véanse Furet, François y Halévi, Ran, La Monarchie..., cit., pp. 184-186; Fioravanti, M. Los derechos fundamentales, cit., pp. 78 y 79 
Este libro forma parte del acervo de la Biblioteca Jurídica Virtual del Instituto de Investigaciones Jurídicas de la UNAM

sido retenida, ni en su orden lógico, ni en los términos del mismo. ${ }^{98} \mathrm{Si}$ bien no se puede adjudicar a Sieyès el mérito de haber sido precursor u original en su aportación, en cambio es el suyo el de haberla fundamentado mejor que nadie y de la manera más coherente. ${ }^{99}$ De ahí el peso y la importancia de su impronta en la concepción final. El memorándum leído en las sesiones del 20 y 21 de julio de 1789 consta de una larga y sustanciosa argumentación y de treinta y dos artículos.

En la nota introductoria distinguió dos formas "de presentar las grandes verdades a los hombres": la primera consistía en hacer con ellas una especie de catecismo que facilitara su memorización; la segunda en exponerlas lógicamente concatenadas, a fin de no privarlas de su carácter esencial, que era "la razón y la evidencia". ${ }^{100}$ Obvio es decir que era esta segunda forma de presentación la que prefería, pero, no sin cierto desprecio, hizo una concesión a la primera que estaba de moda. Es en la argumentación que precede al articulado donde podemos extraer lo más notable de su reflexión.

Según Sieyès, "toda unión social y, por consecuencia, toda constitución política no puede tener más objeto que el de manifestar, ampliar y garantizar los Derechos del Hombre y del Ciudadano". Al ejercer el poder constituyente, los representantes de la nación asumen que deben obligarse "a reconocer tales derechos, y que "su exposición razonada debe anteceder al plan de constitución, por ser su preámbulo indispensable”, siendo una

98 Ibidem, p. 320. El acta levantada con motivo de las elecciones en la circunscripción de la Sarthe a la Convención, donde Sieyès resultó electo, lo llama "el inmortal autor de la Declaración de los Derechos el Hombre", como un reconocimiento que sus contemporáneos hicieran de la importancia de su influencia. Bastid, Paul, La place..., cit., p. 309.

99 Cfr. Bastid, Paul, Sieyès..., cit., pp. 359 y 360.

100 Sieyès, Emmanuel-Joseph, "Preliminar de la Constitución. Reconocimiento y exposición razonada de los Derechos del Hombre y del Ciudadano", en Pantoja Morán, David (comp.), Escritos políticos de Sieyès, México, Fondo de Cultura Económica, 1993, p. 177. 
Este libro forma parte del acervo de la Biblioteca Jurídica Virtual del Instituto de Investigaciones Jurídicas de la UNAM

condición necesaria, ya que es una especie de ley suprema que está por encima de la Constitución. ${ }^{101}$

$\mathrm{Su}$ individualismo optimista y finalista le hizo ver al hombre, si bien sometido a sus necesidades, no por ello menos poseedor de los medios para satisfacerlas y teniendo como finalidad su bienestar. "El objeto de la unión social es la dicha de los asociados", concluyó. ${ }^{102}$

El concepto que se hizo de la libertad estaba íntimamente asociado al de propiedad, porque afirmaba que "es libre todo aquel que está seguro de que no se le molestará en el ejercicio de su propiedad personal y en el uso de su propiedad real". En su formulación pareciera ver en la propiedad el argumento o la condición no sólo de la libertad, sino la del resto de los derechos, pues, garantizada la seguridad para aquélla, "el ciudadano tiene derecho de quedarse, de ir, de pensar, de hablar, de escribir, de imprimir, de publicar, de trabajar, de producir, de conservar, de transformar, de intercambiar y de consumir, etc."103

Para confirmar esta última idea basta con volver a párrafos anteriores, donde se establece la ligazón entre libertad y propiedad. La libertad - dice - se ejerce sobre cosas "comunes" y "propias". Afirmaba que la propiedad de la "persona" es el primero de los derechos y que de este derecho primitivo deriva la propiedad de las "acciones" y la del "trabajo". En una analogía con el cuerpo humano que se apropia del aire, del agua, de los frutos y los transforma y hace suya su substancia así, el individuo, con su trabajo, transforma los objetos, los prepara para su uso y se hace propietario de su trabajo invertido y del objeto mismo y esta propiedad es sancionada por la legalidad del Estado. ${ }^{104}$ Aquí es necesario resaltar la notable coincidencia de su postura con la de Locke. ${ }^{105}$

101 Ibidem, pp. 177 y 178.

102 Ibidem, pp. 178 y 179.

103 Ibidem, pp. 180 y 181.

104 Ibidem, p. 180.

105 Locke, John, Essai sur le pouvoir civil, París, PUF, 1953, pp. 81 y 82. 
Este libro forma parte del acervo de la Biblioteca Jurídica Virtual del Instituto de Investigaciones Jurídicas de la UNAM

$\mathrm{Al}$ establecer los límites de la libertad, lo delata su inequívoca militancia liberal: "los límites de la libertad individual no están colocados sino en el punto donde comenzaría a dañar la libertad de otro".

A este propósito, Macpherson señala que en los orígenes del individualismo en el siglo XVII existe un rasgo esencial: este individualismo "es la afirmación de una propiedad, es esencialmente propietario". Por lo que designa a la tendencia que considera que el individuo no es de ninguna manera deudor frente a la sociedad por su propia persona o por su capacidad, de las cuales es, al contrario, su propietario exclusivo. En esta época - afirma- el individuo no es concebido como un todo moral, ni como parte de un todo social que lo rebasa, sino como su propio propietario; es decir, que se atribuyen retrospectivamente a la naturaleza misma del individuo las relaciones de propiedad. Se piensa que el individuo no es libre, sino en la medida en que es propietario de su persona y de sus capacidades. Ahora bien, la esencia del hombre es ser libre, independientemente de la voluntad de otro, y esa libertad es función de lo que posee. La sociedad, en esta perspectiva, se reduce a un conjunto de individuos libres e iguales, ligados unos a otros en tanto son propietarios de sus capacidades y de lo que el ejercicio de éstas les ha permitido adquirir, y la sociedad política no es sino un artificio destinado a proteger esta propiedad y a mantener el orden en las relaciones de intercambio. ${ }^{106}$

Otro tema de gran envergadura en la argumentación de Sieyès es la igualdad:

Dos hombres siendo igualmente hombres, tienen, en igual grado, todos los derechos que derivan de la naturaleza humana. Así, todo hombre es propietario de su persona o nadie lo es... Existen, es cierto, grandes desigualdades de medios entre los hombres. La naturaleza hace fuertes y débiles; reparte a unos inteligencia que rehusa a otros. Se sigue que ahí habrá entre ellos desigualdad

106 Macpherson, Crawford Braugh, La théorie politique de l'individualisme possesif. De Hobbes á Locke, París, Gallimard, 1971, p. 13. 
Este libro forma parte del acervo de la Biblioteca Jurídica Virtual del Instituto de Investigaciones Jurídicas de la UNAM

de trabajo, desigualdad de producto, desigualdad de consumo o de disfrute, pero no se sigue que pueda haber ahí desigualdad de derechos... En consecuencia, el estado social no establece una injusta desigualdad de derechos, al lado de la desigualdad natural de los medios; al contrario, protege la igualdad de los derechos contra la influencia natural, pero perniciosa, de la desigualdad de los medios. ${ }^{107}$

Una aportación más de Sieyès acrecentaría la deuda que con él tiene el constitucionalismo, la cual consiste en la distinción entre derechos naturales y civiles, por una parte; y entre derechos políticos, por la otra. La diferencia que separa a unos y a otros radica en que los derechos naturales y civiles son aquellos para cuyo mantenimiento y desarrollo se ha formado la sociedad y los derechos políticos son aquéllos mediante los que la sociedad se forma; llama a los primeros pasivos y a los segundos activos. ${ }^{108}$

Con una terminología que al igual que la de sus contemporáneos es aún poco precisa, parece erigir, según Bastid, una construcción de tres pisos. En la base, los derechos naturales, poco numerosos, pero casi absolutos sólo limitados por la moral universal. En medio, los derechos del ciudadano que, en parte, son los derechos naturales reflejados en el régimen civil y que también son derechos nuevos cuyo objeto es creado por la asociación misma. En la cima, al fin, los derechos políticos más restringidos en su objeto y que pertenecen sólo a una élite. ${ }^{109}$

Rabaut Saint-Etienne (pastor protestante electo por el Tercer Estado en la circunscripción de Nîmes) intervino en el momento de pasar a la fase final de la redacción, para resaltar la liga fundamental entre la declaración que se iba a redactar y la Constitución. A diferencia de los americanos, la Asamblea debía no sólo declarar los derechos del hombre, sino hacer de ellos la piedra

107 Sieyès, Emmanuel-Joseph, "Preliminar de la Constitución...", cit., pp. 178,179 y 180 .

108 Ibidem, p. 183.

109 Bastid, Paul, Sieyès..., cit., pp. 363 y 364. 
Este libro forma parte del acervo de la Biblioteca Jurídica Virtual del Instituto de Investigaciones Jurídicas de la UNAM

angular de la organización de los poderes. En esta idea, tomada de Sieyès, consistía la originalidad de la regeneración francesa, según Rabaut.

Habéis adoptado el partido de la Declaración de los Derechos porque vuestros cuadernos os imponen el deber de hacerlo y vuestros cuadernos os han hablado de ellos porque Francia ha tenido a América por ejemplo. Pero que no se os diga por ello que nuestra declaración debe ser semejante. Las circunstancias no son las mismas: ella rompía con una metrópoli alejada, era un pueblo nuevo que destruía todo para todo renovar... No obstante, existe una circunstancia que nos aproxima a su revolución, es que, como los americanos, queremos regenerarnos y la Declaración de los Derechos es, en consecuencia, esencialmente necesaria... La primera idea que ella invoca es menos la de declarar los derechos que la de constituirse; pues ella es una parte integrante de la constitución y los principios de la constitución deben encerrar todas las máximas de gobierno... La Declaración de Derechos no debe ser, de alguna forma, sino el preámbulo de la constitución... Si la Asamblea Nacional se decide por una declaración no debe seguir servilmente y limitarse al ejemplo de los Estados Unidos. Terminó pidiendo a la comisión de redacción que se adoptara el proyecto de Sieyès. ${ }^{110}$

Una primera observación del texto finalmente aprobado de la Declaración, que consta de una breve introducción y de diecisiete artículos, consiste en la interdependencia profunda entre la parte dogmática y la parte orgánica de que constan las Constituciones modernas, en esta es más acusada no sólo porque las dos partes forman un único cuerpo, sino porque la Declaración contiene principios orgánicos de gobierno de la primera importancia, que dan testimonio de la influencia que tuvo el debate y las decisiones tomadas a propósito de la Declaración del 26 de agosto sobre la orientación y el sentido final de las demás deter-

110 Rabaut Saint-Étienne, Jean Paul, "Sur les droits de l'homme", en La monarchie républicaine, op. cit., pp. 390 y 391. 
Este libro forma parte del acervo de la Biblioteca Jurídica Virtual del Instituto de Investigaciones Jurídicas de la UNAM

minaciones de la Constitución. Por ello, es que se ha hecho notar que la Declaración contiene dos categorías de derechos: los derechos del hombre y los derechos de la nación.

En efecto, el artículo 3o. de la Declaración contiene un principio que transforma de pies a cabeza el sistema político, se trata del traslado de sede del principio de legitimidad del rey a la nación: "el principio de toda soberanía reside esencialmente en la Nación. Ningún cuerpo, ningún individuo puede ejercer autoridad que no emane de ella expresamente". Los temores de Mirabeau, quien se oponía a la transformación de los Estados Generales en la Asamblea Nacional se vieron confirmados, pues la conclusión era inevitable, se terminaría por destronar al rey, despojándolo de la soberanía para otorgársela a la nación. Dada la importancia del tema, volveremos a él en un apartado especial.

$\mathrm{Al}$ respecto, Fioravanti señala que en contraposición con el Antiguo Régimen existen en la Declaración de 1789 dos valores político-constitucionales: el individuo y la ley como expresión de la soberanía de la nación. Al artículo 2o. que establece que el fin de toda asociación política es la conservación de los derechos naturales e imprescriptibles del hombre, responde el artículo 3 o. que prescribe que el principio de toda soberanía reside esencialmente en la nación. Ninguna corporación o individuo puede ejercer una autoridad que no emane expresamente de ella. Estos dos artículos — según él- fijan las coordenadas generales de un modelo político que al mismo tiempo libera al individuo y al Estado - manifestado éste en los términos de la soberanía de la nación - de la presencia de los viejos poderes feudales y señoriales. La afirmación de los derechos naturales individuales y de la soberanía nacional no son realidades completamente opuestas en la Declaración de 1789, continúa. Al contrario, ambas se toman como hijas del mismo proceso histórico, que al mismo tiempo que libera al individuo de las antiguas ligaduras del señorjuez o del señor-recaudador, libera también al ejercicio del poder público en nombre de la nación de las influencias nefastas 
Este libro forma parte del acervo de la Biblioteca Jurídica Virtual del Instituto de Investigaciones Jurídicas de la UNAM

en sentido disgregante y particularista de los poderes feudales y señoriales. ${ }^{111}$

Otro tema que evidencia la vinculación estrecha entre la parte dogmática y la parte orgánica de la constitución lo proporciona el artículo 16 de la Declaración que consagra el principio que, según el pensamiento liberal, es desiderátum y garantía de los derechos individuales: "toda sociedad en la que la garantía de los derechos no esté asegurada, ni la separación de poderes determinada, carece de constitución". El tema de la separación y organización de los poderes también será objeto de análisis más adelante.

La única diferencia entre el texto de la introducción de la Declaración, finalmente aprobada, y el proyecto presentado por Mirabeau consiste en que el primero invoca al "ser supremo" y el segundo no; el primero "declara" los derechos y el segundo los "restablece". Salvo esto, ambas son idénticas.

Desde las primeras líneas de la introducción de la Declaración aparece uno de los trazos dominantes de l'esprit du siècle, a saber, la noción de la bondad natural del hombre, así como el rechazo de la idea cristiana del pecado original como explicación teológica de las desgracias humanas. En efecto, esta primera idea de la Declaración atribuye a la ignorancia, al olvido o al desprecio de los derechos humanos las causas de las desgracias públicas y de la corrupción gubernamental. La Declaración tiene por objeto estar presente en todos los miembros de la sociedad, recordándoles sus deberes y derechos, con el propósito de que la conducta de los poderes Legislativo y Ejecutivo pueda ser comparada con las metas de toda institución política y a fin de que las reclamaciones de los ciudadanos, ahora fundadas en principios, conlleven al mantenimiento de la Constitución y a la felicidad de todos.

Los dos primeros artículos contienen declaraciones con amplitud universal siendo, en el primero, recalcadas las libertades y, en el segundo, los derechos naturales. No se plantean cuáles eran

111 Fioravanti, Maurizio, Los derechos fundamentales..., cit., p.58. 
Este libro forma parte del acervo de la Biblioteca Jurídica Virtual del Instituto de Investigaciones Jurídicas de la UNAM

los derechos particulares de los ciudadanos franceses, sino cuáles eran los derechos generales de los hombres, considerándolos de una manera abstracta fuera de cualquier sociedad en particular: "los hombres nacen y permanecen libres e iguales en derechos. Las distinciones sociales no pueden estar fundadas más que en la utilidad común... El fin de toda asociación política es la conservación de los derechos naturales e imprescriptibles del hombre. Esos derechos son la libertad, la propiedad, la seguridad y la resistencia a la opresión".

El concepto liberal de libertad, cuyo límite es la libertad del otro y está señalado por la ley, es el sentido de los artículos 3o. y 4o., "la libertad consiste en poder hacer todo lo que no daña al otro... La ley no tiene el derecho de prohibir más que los actos dañinos a la sociedad. Todo lo que no está prohibido por la ley no puede ser impedido y nadie puede ser obligado a hacer lo que ella no ordena".

La concepción rousseauniana de la ley como "expresión de la voluntad general" es retomada en el artículo 6o., junto a su consecuencia: "todos los ciudadanos tienen derecho de concurrir personalmente, o a través de sus representantes, a su formación". A decir de Fioravanti, la alternativa entre democracia directa y sistema representativo quedó abierta con la formulación este añadido. ${ }^{112}$

En el mismo artículo se consagra una explicitación del derecho a la igualdad, ya que la ley "debe ser la misma para todos, sea que proteja, sea que castigue. Todos los ciudadanos, siendo iguales ante sus ojos, son igualmente admisibles a todas las dignidades, plazas y empleos públicos, según sus capacidades y sin otra distinción que la de sus virtudes y de sus talentos".

Si bien por ser una declaración de carácter universal, dirigida al hombre en abstracto, ha sido caracterizada como un catecismo filosófico y se ha puesto el acento en su carácter metafísico, la

112 Fioravanti, Maurizio, "Estado y constitución", en Fioravanti, Maurizio (ed.), El Estado moderno en Europa. Instituciones y derecho, Madrid, Trotta, 2002, p. 24. 
Este libro forma parte del acervo de la Biblioteca Jurídica Virtual del Instituto de Investigaciones Jurídicas de la UNAM

presencia de los abogados, de los notarios y de esos propietarios que habían sido elegidos por el Tercer Estado, impuso también un muy vivo sentido de lo real, un sentido agudo de lo cotidiano y de los intereses terrenos, en los siguientes artículos.

Los artículos 7o., 8o. y 9o. consagran garantías procesales, protectoras de la libertad del hombre. Los artículos 10, 11 y 17 se ocupan de la tolerancia religiosa, de la libertad de imprenta y de la difusión de las ideas.

Final y sumariamente, los artículos 12, 13, 14 y 15 establecen la fuerza pública como garantía de los derechos individuales; las contribuciones comunes e igualitarias, para sostener esa fuerza pública y los gastos de administración, y el derecho de los ciudadanos para comprobar la necesidad de la contribución, aprobarla libremente y darle seguimiento a su empleo. También se establece el derecho de la sociedad de exigir rendimiento de cuentas a los agentes públicos. ${ }^{113}$

Los decretos de la noche del 4 de agosto y la Declaración de Derechos representan la culminación de una evolución lenta que a partir del siglo XII llevaba a cabo la sociedad francesa hacia el triunfo del individualismo y a un sistema político fundado en la idea de soberanía nacional. Al otorgársele todas las libertades al individuo, éste se convirtió en el centro de un sistema jurídico y político que procedía del pensamiento liberal del siglo XVIII. Si bajo el antiguo régimen el centro y origen de la autoridad y del poder era el rey y la razón de ser de todo el sistema administrativo, político y judicial del país era el fortalecimiento de la autoridad del monarca, para el nuevo régimen en construcción, el origen del poder estaba en la nación y la razón de ser de los servicios administrativos y judiciales consistía en asegurar a los individuos, cuyo haz constituía la nación, su independencia frente al Estado. Otra gran transformación fue la relativa a la abolición de la propiedad privilegiada y a la creación de un concepto exclusivamente

113 Véase la versión completa en "Declaration des Droits de l'Homme et du Citoyen (26 de agosto de 1789)", ibidem, pp. 263-265. 
Este libro forma parte del acervo de la Biblioteca Jurídica Virtual del Instituto de Investigaciones Jurídicas de la UNAM

individual de la propiedad, pues la cancelación de los derechos feudales, base de los tributos señoriales, estableció los fundamentos de una sociedad de individuos iguales ante la ley. ${ }^{114}$

Me parece útil ofrecer también al lector algunas particularidades que ofrecen otros proyectos de declaración que por su especificidad puedan tener interés. En el proyecto de Sieyès se concibía a toda sociedad como "la obra libre de una convención entre todos los asociados" y el objeto de la sociedad política como "el más gran bien para todos". Era más prolija, con más detalles y mejor articulada la lista de derechos individuales que propuso.

Su artículo 9o. contiene una redacción que siempre me ha parecido difícil de desentrañar: "la libertad, la propiedad y la seguridad de los ciudadanos debe fundarse sobre una garantía social superior a todos los menoscabos". La garantía social a que se refiere Sieyès en este artículo puede ser la fuerza pública, que es mencionada en el artículo subsecuente; pero más bien parece referirse a la Constitución misma, pues una vez que los derechos individuales hubieran sido elevados a rango constitucional, la garantía de no ser vulnerados residiría en su inclusión en el texto de la Constitución.

Se establece que el poder militar sólo debe usarse para la defensa externa y jamás contra los ciudadanos, también la solidaridad como un derecho: "todo ciudadano que esté en la imposibilidad de proveer a sus necesidades tiene derecho a la ayuda de sus conciudadanos".

Paralelamente a la responsabilidad de los funcionarios públicos se prevé la inmunidad del rey y la inviolabilidad de su persona. Esta previsión normativa es sorprendente cuando se recuerda que, más tarde, Sieyès votó a favor de la condena a muerte de Luis XVI.

114 Pirenne, Jacques, Historia universal, Barcelona, Ed. Éxito, 1973, vol. V, pp. 18-26. Véase a este respecto Córdova Arnaldo, "La concepción jurídicopolítica de Kant", del mismo autor, "De Grocio a Kant. Génesis del concepto moderno de propiedad", Sociedad y Estado en el mundo moderno, México, Grijalbo, 1976. 
Este libro forma parte del acervo de la Biblioteca Jurídica Virtual del Instituto de Investigaciones Jurídicas de la UNAM

No deja de sorprender también que en una declaración de derechos se incluya el derecho del pueblo a revisar y reformar la Constitución y aún de determinar épocas fijas en que se debiera tener esta revisión, cualquiera que fuera la necesidad de hacerlo.

Finalmente, pero no menos importante, es que si bien el proyecto aprobado recoge la idea de Rousseau de concebir a la ley como "expresión de la voluntad general", Sieyès la vincula con el sistema representativo, "en un gran pueblo [la ley] debe ser la obra de un cuerpo de representantes escogidos por corto tiempo, mediata o inmediatamente por todos los ciudadanos que tienen interés y capacidad en la cosa pública. Esas dos cualidades tienen necesidad de ser positiva y claramente determinadas por la constitución". ${ }^{115}$

Del proyecto de la comisión que encabezaba Mirabeau es digno de resaltar que se consagró en el artículo 2o. una idea de Rousseau, que es fundamento del totalitarismo, "todo cuerpo político recibe existencia de un contrato social, expreso o tácito, por el cual cada individuo pone en común su persona y sus facultades bajo la suprema dirección de la voluntad general y, al mismo tiempo, el cuerpo recibe a cada individuo como porción." 116

Una última cuestión en relación a este tema es la relativa al distingo que la doctrina haría entre "derechos" del hombre concebidos como preexistentes a toda ley e incluso a todo orden social, a los que el orden jurídico no los crea, sino que simplemente los supone - y las "garantías" consagradas constitucionalmente - éstas sí establecidas o concedidas por el orden jurídico, para hacer efectivo el libre ejercicio de aquellos derechos - distinción cuyo origen parece tener lugar en la Asamblea Constituyente.

115 Véase la versión completa en Sieyès, Emmanuel-Joseph, "Preliminar de la Constitución...", cit., pp. 177-189.

116 Véase la versión completa en "Projet de Declaration des Droits de l'Homme en societé (17 de agosto de 1789)", Les Declarations de Droits de l'Homme de 1789, París, Payot, 1992, pp. 333-335. En relación con esta vertiente totalitaria de Rousseau, $c f r$. Talmon, Jacob Lieb, Les origines de la démocratie totalitaire, París, Calman-Levy, 1966. 
Este libro forma parte del acervo de la Biblioteca Jurídica Virtual del Instituto de Investigaciones Jurídicas de la UNAM

Como se recordará, la Declaración de los Derechos del Hombre y del Ciudadano fue aprobada el 26 de agosto de 1789, decidiéndose que sirviera de preámbulo a la Constitución y, por otra parte, el texto definitivo de ésta no fue aprobado sino hasta el 3 de septiembre de 1791, mismo en el que se incluye el título uno denominado "Disposiciones fundamentales garantizadas por la Constitución” ¿Habría tenido algún sentido para la Asamblea Constituyente hacer una simple repetición de conceptos en el mismo cuerpo de normas o bien la Asamblea hizo la distinción?

En todo caso, ese título uno hace una larga enumeración de garantías. En un primer apartado se refiere a la igualdad: "la constitución garantiza como derechos naturales y civiles... que todos los ciudadanos sean admisibles a los lugares y empleos, sin otra distinción que la de sus virtudes y sus talentos... que todas las contribuciones sean repartidas entre todos los ciudadanos igualmente en proporción a sus facultades... que los mismos delitos sean castigados con las mismas penas, sin ninguna distinción de personas".

En un segundo párrafo se garantizan las libertades:

La constitución garantiza paralelamente, como derechos naturales y civiles la libertad a todo hombre de ir, permanecer, partir, sin poder ser detenido ni impedido, según las formas determinadas por la constitución; la libertad a todo hombre de hablar, escribir, imprimir y publicar sus pensamientos sin que los escritos puedan estar sometidos a ninguna censura ni inspección antes de su publicación y de ejercer el culto religioso al que esté ligado; la libertad a los ciudadanos de reunirse pacíficamente y sin armas, satisfaciendo las leyes de policía; la libertad de dirigir a las autoridades constituidas peticiones firmadas individualmente.

En un tercer párrafo se garantizan los derechos contra la intervención del Legislativo:

El Poder Legislativo no podrá hacer ninguna ley que comporte daño y ponga obstáculo al ejercicio de los derechos naturales 
Este libro forma parte del acervo de la Biblioteca Jurídica Virtual del Instituto de Investigaciones Jurídicas de la UNAM

y civiles consignados en el presente título, y garantizados por la constitución, pero como la libertad no consiste sino en poder hacer todo aquello que no vulnere ni a los derechos de otro, ni a la seguridad pública, la ley puede establecer penas contra los actos que atacando o a la seguridad pública o a los derechos de otro, sean nocivos para la sociedad.

En un párrafo más la propiedad es objeto de garantía:

La constitución garantiza la inviolabilidad de las propiedades o la justa y previa indemnización de aquéllas de las que la necesidad pública, legalmente comprobada, exigiría el sacrificio. Los bienes destinados a los gastos del culto y a todos los servicios de utilidad pública, pertenecen a la Nación, y están en todo tiempo a su disposición. La constitución garantiza las enajenaciones que hayan sido o que sean hechas siguiendo las formas establecidas por la ley.

Más adelante, se garantizan una serie de derechos muy diversos, desde el derecho de elegir ministros de culto hasta el de la instrucción pública gratuita, pasando por el de la ayuda social organizada en beneficio de menores abandonados, enfermos menesterosos y personas sin trabajo, etcétera.

\section{LA IDEA DE SOBERANÍA}

La Revolución francesa llevó a cabo una transformación que como se ha dicho antes, cimbró de arriba abajo todo el sistema de creencias, valores y justificaciones del poder: el título divino de los reyes para gobernar fue substituido por el de la soberanía de la nación, planteando así el problema de diferente manera, no sólo frente a la concepción teocrática de la soberanía, sino también frente a la concepción democrática de Rousseau.

En efecto, a partir de la transformación en el derecho público francés, generada por la Revolución, son dos las ideas que irían a contrapelo y que se disputarían un lugar en las Constituciones $\mathrm{y}$, aunque aparentemente sean semejantes, difieren en cuanto a 
Este libro forma parte del acervo de la Biblioteca Jurídica Virtual del Instituto de Investigaciones Jurídicas de la UNAM

sus alcances y consecuencias sobre las instituciones. Me refiero a las ideas de filiación rousseauniana que postulan el principio de soberanía popular y a las nacidas de la Asamblea Constituyente del 89 al 91 que sostienen la idea de soberanía nacional.

El contrato social que propuso Rousseau era el fundamento de la sociedad, del Estado y de la soberanía, pues su objeto no era solamente producir "un cuerpo moral y colectivo" con las personas de los contratantes, sino también, y esencialmente, crear en el seno de la sociedad una autoridad pública, instancia suprema que resolviera los asuntos de la comunidad. En virtud del contrato, los asociados formarían "el pueblo", que no era sino esta instancia suprema; e individualmente, cada uno de ellos sería "ciudadano", en tanto que partícipe de la autoridad soberana y, al mismo tiempo, sería "súbdito", por estar sometido a las leyes de esa comunidad. Esta "voluntad general" o "yo común" era, entonces, el soberano, ya que según Rousseau, “...así como la naturaleza da a cada hombre un poder absoluto sobre sus miembros, el pacto social da al cuerpo político un poder absoluto sobre todos los suyos y es este mismo poder el que, dirigido por la voluntad general, lleva, como ya dije, el nombre de soberanía...". ${ }^{117}$

Para Rousseau, la soberanía era el ejercicio mismo de la voluntad general, por lo que la concebía "inalienable" y en tanto que era general esta voluntad, la concebía "indivisible". ${ }^{118}$

Si bien, como se ha dicho, cada miembro contratante era partícipe individualmente de la autoridad soberana, entonces, estaba llamado a concurrir con su voto y consentimiento a la formación de la voluntad general, ya que ésta se componía de tantos "miembros como votos tiene su asamblea", de aquí resulta que la soberanía tenía esencialmente su sede en el pueblo; es decir, en los individuos mismos de los que el pueblo se componía, en cada uno de los miembros de ese pueblo contados uno a uno. ${ }^{119}$

117 Rousseau, Jean-Jacques, Du contrat social, Ginebra, Les editions du cheval ailé, 1947, p. 214.

118 Ibidem, p. 208.

119 Ibidem, p. 196. 
Este libro forma parte del acervo de la Biblioteca Jurídica Virtual del Instituto de Investigaciones Jurídicas de la UNAM

Esta idea la concretó afirmando que el soberano no estaba formado sino de las partículas que lo componían, “...supongamos que el Estado está compuesto por diez mil ciudadanos. El soberano no puede considerarse como individuo. Así, el soberano es el súbdito como diez mil es a uno; es decir, que cada miembro del Estado no tiene por su parte sino la diez milésima parte de la autoridad soberana, aunque esté sometido enteramente a ella". ${ }^{120}$

Ya habrá ocasión más adelante de analizar, de manera circunstanciada, las consecuencias que tuvo la adopción de la idea de la soberanía popular sobre las instituciones, por lo pronto sólo se consigna una: si para Rousseau la ley era expresión de la voluntad general y era al pueblo a quien correspondía emitirla imperativamente, sin importar su objeto, parece desprenderse consecuentemente que, para este autor, no existía diferencia entre poder constituyente y Poder Legislativo constituido, pues, en todos los casos era la voluntad general, titular de la soberanía, la que intervenía y, en consecuencia, no existía diferencia entre ley constitucional o fundamental, por intangible, y la ley ordinaria. Más aún, tal distinción carecía de sentido en el pensamiento de Rousseau, puesto que la voluntad general, en tanto que la legisladora soberana no podía estar sometida a una voluntad superior a la suya, ya que no había, ni podía haber ninguna especie de ley fundamental obligatoria para el cuerpo del pueblo, ni aún el mismo "contrato social". ${ }^{121}$

Por otra parte, para la teoría liberal, la finalidad práctica de tal distinción fue la de colocar fuera del alcance de la autoridad legislativa ordinaria a los derechos y principios consagrados en la constitución, y en la doctrina de Rousseau, en cambio, no existían derechos individuales, concebidos como intangibles, ya que el contrato social se realizaba bajo la base de "la enajenación total de cada asociado, con todos sus derechos a la comunidad entera". ${ }^{122}$

120 Ibidem, p. 254.

121 Ibidem, pp. 194 y 195.

122 Ibidem, p. 192. 
Este libro forma parte del acervo de la Biblioteca Jurídica Virtual del Instituto de Investigaciones Jurídicas de la UNAM

Aunque de manera general se puede afirmar que la idea que postula la titularidad de la soberanía de la nación tiene su origen en Rousseau, la interpretación y el desarrollo de su pensamiento la lleva a diferir en sus alcances y consecuencias. Efectivamente, de la afirmación del "contrato social", por la que el acto de asociarse produce un cuerpo moral y colectivo, que recibe de ese contrato su "yo común", una "vida", una "voluntad", la Asamblea de 1789-91 infirió la concepción de la unidad orgánica de la nación y transfirió la soberanía a la nación-persona. ${ }^{123} \mathrm{Y}$ el diputado constituyente que formulara esta concepción de la manera más coherente y cabal, sin duda fue el abate Sieyès, como podrá verse. Meses antes de que los Estados Generales se constituyeran en Asamblea Nacional, en efecto, en sus primeros trabajos, pero especialmente en ¿Qué es el Tercer Estado?, explicaría con claridad que se trataba de una transferencia de soberanía o, si se quiere, de la reaprehensión por la nación de sus derechos imprescriptibles delegados a una Asamblea Constituyente. Aquí, por cierto será preciso señalar desde ahora que el término soberanía no aparece en los textos de Sieyès sino bajo formas negativas o de crítica. $^{124}$

A diferencia de Rousseau que veía en cada miembro de la comunidad un portador de la soberanía y, por tanto, cada uno individualizadamente era fuente de legitimidad, Sieyès depositó la soberanía en una totalidad indivisible, la nación, a quien le atribuye el origen del poder: “...Todos los Poderes Públicos, sin distinción, son una emanación de la voluntad general; todo viene del pueblo; es decir, de la Nación. Estos dos términos deben ser sinónimos...". Es precisamente a la teoría del poder constituyente de la nación, aquí sucintamente enunciada, que Pasquino

123 Cfr. Hauriou, André, Droit constitutionnel et institutions politiques, París, Ed. Montchrestien, 1968, p. 303.

124 Sieyès, Emmanuel-Joseph, Opinión de Sieyès sobre varios artículos de los títulos IVy V del proyecto de Constitución, en Pantoja Morán, David (comp.), Escritos políticos de Sieyès, México, Fondo de Cultura Económica, 1993, p. 243 y 244. 
Este libro forma parte del acervo de la Biblioteca Jurídica Virtual del Instituto de Investigaciones Jurídicas de la UNAM

atribuye el silencio al que Sieyès somete al término conceptual de soberanía. ${ }^{125}$

En un párrafo posterior eliminó la posibilidad de que otra entidad, distinta a la nación, detentara el poder, pues como ésta era una entidad abstracta, una persona moral y no física necesitaba de representantes o mandatarios que la ejercieran no como un derecho suyo, sino en nombre y representación de la nación. Es de esta manera que se dan por sentadas las bases del régimen representativo:

...El mandatario público, cualquiera que sea su puesto, no ejerce, en consecuencia, un poder que le pertenezca como propio: es el poder de todos; sólo le ha sido confiado y no podrá ser enajenado, pues la voluntad es inalienable; los pueblos son inalienables; el derecho de pensar, de querer y de actuar por sí es inalienable; se puede solamente comisionar el ejercicio de él a quienes tienen nuestra confianza; y esta confianza tiene como carácter esencial el de ser libre... ${ }^{126}$

Esta concepción vendría a ser recogida, como se ha visto, en el artículo 3o. de la Declaración de los Derechos del Hombre y del Ciudadano, aprobada el 26 de agosto de 1789, en los siguientes términos: "el principio de toda soberanía reside en la nación. Ningún cuerpo, ningún individuo puede ejercer autoridad que no emane de ella expresamente." Esta idea sería completada y recibiría formulación cabal en el artículo 1o., título III de la Constitución de 1791: "la soberanía es una, indivisible, inalienable e imprescriptible. Pertenece a la nación; ninguna sección del pueblo, ni ningún individuo puede atribuirse su ejercicio”.

\section{La distinción entre poder constituyente y poderes constituidos}

Una de las aportaciones fundamentales para el constitucionalismo moderno, por sus consecuencias teóricas y prácticas sobre las ins-

125 Pasquino, Pascuale, Sieyès et l'invention..., cit., p. 18.

126 Sieyès, Emmanuel-Joseph, Preliminar de la Constitución..., cit., p. 184. 
Este libro forma parte del acervo de la Biblioteca Jurídica Virtual del Instituto de Investigaciones Jurídicas de la UNAM

tituciones, es la teoría del poder constituyente de Sieyès, que está en vinculación estrecha con la idea de soberanía nacional.

Influidos por Rousseau, los constituyentes del 89 al 91 concibieron en la Constitución a la soberanía "una, indivisible, inalienable e imprescriptible". Sin advertir la contradicción que se produciría en el artículo 16 de la Declaración de Derechos que sirve de preámbulo a la Constitución, como también ya lo hemos señalado, se recogió el principio de la "separación de los poderes". La teoría clásica del constitucionalismo ha reconocido a Sieyès el mérito de haber resuelto la antinomia. ${ }^{127}$

Para la fundamentación de su tesis se aproximó, con ciertas diferencias, al autor clásico del tema de la soberanía, Jean Bodin. En efecto, si para este autor la prueba de que una entidad era soberana residía en la facultad de emitir normas, para Sieyès consistía en la facultad de dotarse de una Constitución. Si para Bodin la instancia soberana era el monarca francés, para Sieyès lo era la nación. En tanto que soberana, pues, la nación estaba colocada por encima de la Constitución y no se encontraba sometida a ella, tal y como Bodin concebía a la instancia soberana supra leges et legibus solutus. ${ }^{128}$

Distinguió a la nación de su organización política para fundar la anterioridad y superioridad de aquélla y explicar así la independencia del poder constituyente y soberano de la nación:

127 Cfrs. Jellinek, Georg, L'État moderne et son droit, París, Ed. Giard et Briére, 1913, t. II, p. 163; Carré de Malberg, Contribution á la théorie générale de l'État, París, Recueil Sirey, 1922 (reimpresión fotomecánica del CNRS), t. II, p. 516; Burdeau, Georges, Traité de Science Politique, París, LGDJ, t. IV, p. 183. En sentido contrario, Tena Ramírez afirma que a partir de Lafayette, que rectificó a Sieyès, ya nadie admite el origen francés de la diferencia entre el Poder Constituyente y Poderes Constituidos, que por otra parte no alcanzó en Francia el desarrollo y la dirección que la caracterizaron en la organización constitucional norteamericana. Tena Ramírez, Felipe, Derecho constitucional mexicano, México, Porrúa, 2000, p. 12.

128 Bodin, Jean, Les six liores de la République, París, Fayard, 1986, libro1, pp. 179-227 y 306 . 
Este libro forma parte del acervo de la Biblioteca Jurídica Virtual del Instituto de Investigaciones Jurídicas de la UNAM

Se debe concebir a las Naciones sobre la tierra como individuos que estuviesen fuera del vínculo social o, como también se dice, en estado de naturaleza... Y esto en razón a que... «la Nación se forma por derecho natural; el gobierno, por el contrario, no puede pertenecer más que al derecho positivo. La Nación es todo lo que puede ser por el solo hecho de existir... No solamente la Nación no está sometida a una constitución, sino que no puede estarlo, no debe estarlo, lo que equivale a decir que no lo está... ¿De quién, en efecto, habría podido la Nación recibir una forma posible? ¿Existe una autoridad anterior que haya podido decir a una multitud de individuos: yo os reúno bajo tales o cuales leyes, porque váis a formar una Nación en las condiciones que yo prescribo?...». ${ }^{129}$

Ya estaba Sieyès en aptitud de resolver la contradicción entre Rousseau, que sostenía la indivisibilidad de la soberanía y Montesquieu, la cual preconizaba la separación de poderes. En efecto, aunque en el acto de establecimiento constitucional se operara una separación y distribución de poderes, este acto era una manifestación de la unidad del poder, en otros términos, aunque a través de la constitución, la Nación delegara el ejercicio de facultades a autoridades "constituidas" y separadas, se reservaba para sí el "poder constituyente", con lo que se preservaba la unidad originaria del poder. Este y no otro es el sentido de su frase cuando dice: "...tal es el verdadero sentido de la palabra constitución; es relativa al conjunto y a la separación de los Poderes Públicos". ${ }^{130}$

Las consecuencias institucionales que se desprenden de esta distinción son de la mayor importancia para el constitucionalismo.

- La unidad indivisible de la soberanía se mantiene originariamente en la nación, fuente constituyente única y común de todos los poderes públicos. Por voluntad del "poder constituyente" de la nación, en la Constitución, la soberanía "se divide para su ejercicio" separadamente entre los diversos poderes constituidos.

129 Sieyès, Emmanuel-Joseph, ¿Qué es el Tercer...?, cit., pp. 157 y 158.

130 Sieyès, Emmanuel-Joseph, Preliminar de la Constitución..., cit., p. 183. 
Este libro forma parte del acervo de la Biblioteca Jurídica Virtual del Instituto de Investigaciones Jurídicas de la UNAM

- Al guardar en sus manos el poder constituyente, la nación no puede quedar ligada por la Constitución; en cambio, los poderes constituidos permanecen sometidos a ella.

- El poder constituyente es un poder de decisión, creador, originario, sin límites jurídicos. Los poderes constituidos, por lo contrario, son poderes de ejecución, derivados, secundarios, limitados y determinados en su forma y actividades. ${ }^{131}$

- Se puede distinguir el poder constituyente del poder reformador de la Constitución y, éste, de los poderes constituidos. ${ }^{132}$

- Se puede distinguir norma constitucional o fundamental y normas ordinarias. Distinción que permite colocar fuera del alcance del Poder Legislativo constituido o legislador ordinario los derechos individuales consagrados en la Constitución.

\section{La idea de soberanía y el sistema representativo.}

La delegación del ejercicio de competencias

Al señalar como una de las cualidades de la soberanía a la "inalienabilidad", Rousseau extrajo como consecuencia lógica la imposibilidad de su delegación. Para este autor si un pueblo era verdaderamente soberano, no podía darse representantes, sin enajenar verdaderamente su soberanía: “...afirmo, pues, que no siendo la soberanía sino el ejercicio de la voluntad general, no puede jamás enajenarse y que el soberano, que no es más que un ser colectivo, no puede ser representado sino por él mismo: el poder se puede transmitir, pero no la voluntad". ${ }^{133}$

131 Cueva, Mario de la, Apuntes para el curso de derecho constitucional, México, Mimeo, 1964.

132 Cueva, Mario de la, Teoría de la Constitución, México, Porrúa, 1982, pp. 143-148.

133 Rousseau, Jean-Jacques, op. cit., p. 206. 
Este libro forma parte del acervo de la Biblioteca Jurídica Virtual del Instituto de Investigaciones Jurídicas de la UNAM

Congruente con esa afirmación, Rousseau afirmaba la incompatibilidad del régimen representativo con la idea de soberanía popular. En efecto, la soberanía tenía su fuente y residencia en la voluntad general del pueblo y no podía ser enajenada de la misma forma que no era susceptible de estar representada. En otras palabras, por ser la soberanía inalienable, el soberano no podía ceder a nadie el poder de querer, por representación, en su lugar. En buena lógica, esta idea conducía a la democracia directa como forma de gobierno.

Con Carré de Malberg se puede concluir que, para Rousseau, el pueblo no transmitía ni delegaba su soberanía y que no había nadie, así fuera electo popularmente que pudiera pretender expresar la voluntad general en su representación. ${ }^{134}$ En este orden de ideas, al instituir un gobierno, el pueblo no celebraba contrato con él, por lo que éste no tiene en modo alguno el carácter de representante del pueblo, sólo era su comitente:

¿Qué es entonces un gobierno?, se preguntaba, Rousseau, un cuerpo intermediario establecido entre los sujetos y el soberano para su mutua comunicación, encargado de la ejecución de las leyes y del mantenimiento de la libertad, tanto civil como política... Así aquéllos que pretenden que el acto por el que un pueblo se somete a unos jefes, no es contrato, tienen gran razón. No es absolutamente sino una comisión, un empleo en el que, simples oficiales del soberano, ejercen en su nombre el poder del que él les ha hecho depositarios. ${ }^{135}$

No obstante, los partidarios de la idea de soberanía nacional irían a extraer una consecuencia radicalmente opuesta. Al derruir la estructura del edificio feudal y los cimientos sobre los que ésta se erigía, el liberalismo formuló un nuevo proyecto de sociedad y una nueva organización política, basados en presupuestos también nuevos. Por un lado, contaba con la experiencia

\footnotetext{
134 Carré de Malberg, Raymond, Contribution á la Théorie..., cit., p. 204.

135 Rousseau, Jean-Jacques, op. cit., pp. 252 y 253.
} 
Este libro forma parte del acervo de la Biblioteca Jurídica Virtual del Instituto de Investigaciones Jurídicas de la UNAM

histórica de la democracia clásica y, por el otro, con su vivencia, ésta reciente del absolutismo monárquico; sin embargo, optó por una tercera vía que excluye a las otras dos.

Aunque existen voces que discrepan, ${ }^{136}$ se puede afirmar que Sieyès tuvo una fuerte influencia en la construcción del concepto de sistema representativo en el seno de la Asamblea Constituyente del 79-81. En una intervención hecha el 7 de septiembre de 1789, en el debate sobre el veto real, desarrolló los fundamentos de esta aportación importante. Su punto de partida fue la nueva sociedad:

...los pueblos europeos modernos se parecen muy poco a los antiguos. No se trata entre nosotros sino de comercio, agricultura, de fábricas, etc. El deseo de riqueza parece no hacer de todos los estados de Europa sino vastos talleres: se piensa ahí mucho más en la producción y el consumo que en la felicidad. ${ }^{137}$

A Pasquino debemos un comentario esclarecedor sobre el anterior párrafo. Resalta, en primer término, la especificidad de la sociedad moderna y su contraste con la antigua y, por lo mismo, el rechazo a mantener el modelo de organización política de Esparta o Atenas, pues ese mundo ya no se parece al moderno. Enseguida, se pone el énfasis en el contenido de esa modernidad que no es otro que la circunstancia de ser una "sociedad de mercado". Por último, se evidencia el diferente ethos que anima a una sociedad y a otra, ya que el consumo, la producción y la riqueza toman en la sociedad moderna el lugar que en la antigua tenía la felicidad. ${ }^{138}$

136 Cfr. Clavreul, Colette, "Sieyès et la genése de la representation moderne", Revue Française de Théorie Furidique, vol. 6, 1987.

137 Sieyès, Emmanuel-Joseph, "Palabras del abate Sieyès sobre la cuestión del veto real", en Pantoja Morán, David (comp.), Escritos políticos de Sieyès, México, Fondo de Cultura Económica, 1993, p. 211.

138 Pasquino, Pascuale, "Emmanuel Sieyès, Benjamin Constant et le Gouvernement des modernes. Contribution á l'Histoire du concept de representation politique", Revue Française de Science Politique, abril de 1987, pp. 219 y 220. 
Este libro forma parte del acervo de la Biblioteca Jurídica Virtual del Instituto de Investigaciones Jurídicas de la UNAM

Establecidas las características de la sociedad moderna y a partir de ellas, procedió Sieyès a construir conceptualmente la teoría del gobierno representativo, al distinguirlo del tipo de gobierno que correspondía a la sociedad antigua. En este tipo de sociedad - que Sieyès denominó "democracia pura", casi "bruta", por analogía a las materias primas que la naturaleza ofrece al hombre, y que éste con su industria modifica para disfrutarlas"los miembros de la asociación política quieren regirse por sí mismos". En el tipo de sociedad moderna, en cambio, "escoger solamente a algunos de entre ellos para ocuparse de todo lo que las necesidades públicas pueden exigir de cuidados o vigilancia". ${ }^{139}$

Estos dos tipos de gobierno los esclareció aún más, al señalar las dos formas que tienen las sociedades de organizarse políticamente.

Puede ejercerse de dos maneras. Los ciudadanos pueden dar su confianza a algunos de ellos mismos. Sin enajenar sus derechos, confian a otros su ejercicio. Por bien de la utilidad común, se nombran representantes mucho más capaces que ellos mismos de conocer el interés general, y de interpretar a este respecto su propia voluntad. La otra manera de ejercer su derecho a formar la ley es la de concurrir por sí mismos a hacerla inmediatamente. Este concurso inmediato es lo que caracteriza la verdadera democracia. El concurso mediato designa al gobierno representativo. Es enorme la diferencia entre estos dos sistemas políticos. ${ }^{140}$

Carré de Malberg acotaría esta diferencia diciendo que en el régimen democrático el ciudadano es legislador y en el régimen representativo no es sino elector. ${ }^{141}$

Sieyès hizo de la representación la base misma de toda la organización política y, lejos de considerarla como un mal ne-

139 Sieyès, Emmanuel-Joseph, "Observaciones sobre el informe del Comité de Constitución acerca de la nueva organización de Francia”, en Pantoja Morán, David (comp.), Escritos políticos de Sieyès, México, Fondo de Cultura Económica, 1993, pp. 231 y 232.

140 Sieyès, Emmanuel-Joseph, "Palabras del abate Sieyès...", cit., p. 211.

141 Carré de Malberg, Raymond, Contribution á la théorie..., cit., t. II, p. 257. 
Este libro forma parte del acervo de la Biblioteca Jurídica Virtual del Instituto de Investigaciones Jurídicas de la UNAM

cesario, la ubicó como el mejor sistema de gobierno. Influido de manera importante por Smith, Quesnay, Turgot y los fisiócratas, coincidió con ellos en un principio común de análisis sociológico: el de la "división del trabajo". Es esta categoría analítica la que da sustento a su teoría del gobierno en la sociedad de mercado.

...la razón, o al menos la experiencia, le dice además al hombre: tendrás tanto más éxito en tus ocupaciones si sabes limitarlas. Conduciendo todas las facultades de tu entendimiento sobre una parte solamente de los trabajos útiles, obtendrás un producto más grande con menos esfuerzos y menos gasto. De ahí viene la división del trabajo, efecto y causa del acrecentamiento de las riquezas y del perfeccionamiento de la industria humana. Esta materia está perfectamente desarrollada en la obra del doctor Smith. Esta separación es en beneficio común de todos los miembros de la sociedad. La separación corresponde a los trabajos políticos como a todos los géneros del trabajo productivo. El interés común, el mejoramiento del estado social mismo, nos exigen hacer del gobierno una profesión particular... Así, la constitución puramente democrática deviene no solamente imposible en una gran sociedad, sino aún en el Estado menos extenso; ella es mucho menos apropiada a las necesidades de la sociedad, mucho menos conducente al fin de la unión política, que la constitución representativa: tal es la segunda forma legítima de gobierno... ${ }^{142}$

Con agudeza, Pasquino nos señala que la división del trabajo en Sieyès no sólo era un medio de incrementar la productividad al interior de una rama de la producción, sino que era el principio verdadero del progreso social; se trataba, para el abate, de un principio de civilización. Una segunda observación la hace Pasquino, citando el discurso del 2 Termidor, año III, en el que Sieyès remató su pensamiento sobre el sistema representativo de gobierno: “...todo es representación en el Estado social. Se encuentra en todas partes en el orden privado como en el orden público; es la madre de la industria productiva y comercial, como

142 Sieyès, Emmanuel-Joseph, “Observaciones sobre el informe...”, cit., p. 232. 
Este libro forma parte del acervo de la Biblioteca Jurídica Virtual del Instituto de Investigaciones Jurídicas de la UNAM

de progresos liberales y políticos. Digo más, ella se confunde con la esencia misma de la vida social...". ${ }^{143}$

De esta cita, Pasquino extrajo una consecuencia en el plano político constitucional que debe consignarse: en Sieyès la forma representativa de gobierno, lejos de ser una forma menor de gobierno legítimo o una solución técnica propia de los grandes Estados de numerosa población, era al contrario la que mejor correspondía a la sociedad moderna, a la sociedad de mercado. ${ }^{144}$

Para el abate no era indispensable que el pueblo se gobernara a sí mismo para que la libertad estuviera a salvo y, reforzando la idea del párrafo anterior, aún dio a entender que por más de un concepto, los ciudadanos acrecentaban su libertad haciéndose representar por "la parte del establecimiento público" que se encontraba organizada para este efecto. Son otras, las razones que justificaban en Sieyès al régimen representativo, ya que se diluía el argumento de Rousseau de que ante la dimensión de los Estados modernos existía la imposibilidad de la democracia directa.

...reinaba - dice - un error muy perjudicial: el de que el pueblo no debe delegar más poderes que aquéllos que no pueda ejercer por sí mismo. Se vincula a este pretendido principio la salvaguarda de la libertad. Es como si se quisiera probar a los ciudadanos que tienen necesidad por ejemplo, de escribir a Bordeaux, que ellos conservarán mejor su libertad si se reservan el derecho de llevar sus cartas ellos mismos, pues lo pueden hacer, en lugar de confiar su cuidado a esa parte del establecimiento público que de ellos se encarga. ¿Podemos ver los verdaderos principios en tal mal cálculo?... ${ }^{145}$

143 Sieyès, Emmanuel-Joseph, "Opinión de Sieyès sobre varios artículos de los títulos IV y V del proyecto de Constitución”, en Pantoja Morán, David (comp.), Escritos políticos de Sieyès, México, Fondo de Cultura Económica, 1993, p. 242.

144 Pasquino, Pascuale, "Emmanuel Sieyès, Benjamin Constant et le Gouvernement des modernes. Contribution á l'Histoire du concept de representation politique", op. cit., pp. 220 y 221.

145 Sieyès, Emmanuel-Joseph, "Opinión de Sieyès...," op. cit., p. 243. 
Este libro forma parte del acervo de la Biblioteca Jurídica Virtual del Instituto de Investigaciones Jurídicas de la UNAM

En una síntesis afortunada, el vocero de la Comisión redactora vinculó la idea de soberanía nacional como forma representativa de gobierno y mandato representativo:

Sé que el principio de la soberanía reside en la Nación: vuestra Declaración de Derechos contiene esta verdad. Pero ser el principio de la soberanía y ejercer la soberanía son dos cosas muy diferentes; y sostengo con confianza que una Nación sería muy insensata y muy desgraciada si ella retuviera el ejercicio de la soberanía. Se debe entender por esta última palabra la potestad indefinida y absoluta. Así, decir que una Nación es soberana, es decir que una Nación tiene todos los poderes; y, ciertamente nadie duda que una Nación no pueda todo lo que ella quiere, pero ella no debe querer más que lo que le interesa a su felicidad; y como una Nación es un cuerpo colectivo, está ella misma en dirección de choque con las pretensiones y los intereses de aquéllos que la componen. Está desgarrada por facciones y sometida al imperio de la violencia, si no escoge jefes, si no organiza su gobierno y no instituye una fuerza pública. No puede organizar ese gobierno más que delegando su soberanía... Si vosotros deseáis que los electores puedan dar mandatos imperativos, ¿no teméis entonces exponer al reino a todas las incertidumbres, a todos los problemas que nacerán de voluntades directamente contrarias? ¿no teméis, entonces, a la democracia más tumultuosa? Pues, si cada asamblea de distrito puede dictar la ley, vuestra asociación monstruosa no será ni siquiera digna del nombre de gobierno; será disuelta después de haber sufrido las más horribles convulsiones... ${ }^{146}$

Ahora bien, ¿cuál fue el camino lógico que siguió la Asamblea Constituyente del 89-91 para unir la idea de soberanía nacional a la de régimen representativo? Como se ha visto, la Constitución de 1791 consagró en su artículo 1o., título III, el principio de la soberanía nacional, consistente en la idea que la soberanía "pertenece" indivisiblemente "a la nación", esto es, al cuerpo nacional como un todo entero, siendo el mismo indivisi-

146 "Discurso de Mounier sobre la sanción real (5 de septiembre de 1789)", en Furet, François y Halévi, Ran, La Monarchie..., cit., pp. 396 y 397. 
Este libro forma parte del acervo de la Biblioteca Jurídica Virtual del Instituto de Investigaciones Jurídicas de la UNAM

ble. La nación, así considerada, no podía ser confundida con sus miembros individuales. Este todo orgánico, esta unidad que era la Nación, al organizarse formó una entidad que se convirtió en persona jurídica: el Estado, cuya soberanía residía en esta entidad colectiva y unificada y no en los miembros que la formaban. De aquí resulta un principio que recoge el propio artículo lo. de dicha Constitución: "ninguna sección del pueblo, ni ningún individuo, pueden atribuirse el ejercicio" de la soberanía. Y con el artículo 3o. de la Declaración de los Derechos del Hombre y del Ciudadano de 1789 se complementaría el principio, al agregar que "ningún cuerpo, ni ningún individuo podría ejercer autoridad alguna que no emanare [de la Nación] expresamente". Por su parte, el artículo 2o., del título III de la Constitución del 91 se concatena con el principio anterior, al afirmar que es la $\mathrm{Na}$ ción, "de quien únicamente emanan todos los poderes, la que sólo puede ejercerlos por delegación".

En la concepción de delegación de poderes estaba una de las aportaciones fundamentales de la Asamblea Constituyente al derecho público francés y cuya importancia es capital para entender la nueva organización de los poderes públicos: "la nación era la titular originaria de todas las competencias, facultades o poderes" y a través del establecimiento de la constitución "delegaba de éstos solamente el ejercicio", pero no la propiedad, ni el disfrute propiamente dichos a los diversos individuos o cuerpos colegiados. El necesario resultado que entrañaba la concepción de la delegación de poderes era el de la representación nacional y, así, esos individuos o cuerpos colegiados en quienes la Nación delegaba competencias, poderes o facultades eran reputados representantes nacionales. Es así como el artículo 2o. del título III de la Constitución puede afirmar que la constitución francesa es representativa. De esta manera, la idea de soberanía nacional se positivizó en la primera Constitución francesa, a través de la instauración del régimen representativo. ${ }^{147} \mathrm{~A}$ partir de entonces, esta concepción cobró carta de naturalización en el derecho público francés.

147 Carré de Malberg, Raymond, Contribution á la théorie..., cit., pp. 200 y 201. 
Este libro forma parte del acervo de la Biblioteca Jurídica Virtual del Instituto de Investigaciones Jurídicas de la UNAM

Para una cabal comprensión de lo anterior, leamos de corrido lo consagrado en la Constitución que aquí analizamos, en los artículos del 1o. al 5o. del título III: La soberanía es "una, indivisible", inalienable e imprescriptible. Pertenece a la Nación; ninguna sección del pueblo, ni ningún individuo puede atribuirse su ejercicio. La Nación, de la que únicamente emanan todos los poderes, no los puede ejercer sino por delegación. La Constitución francesa es representativa: los representantes son el cuerpo legislativo y el rey. El Poder Legislativo es delegado a una Asamblea Nacional, compuesta de representantes temporales, libremente electos por el pueblo, para ser ejercido por ella, con la sanción del rey, de la forma en que será determinado más adelante. El gobierno es monárquico: el Poder Ejecutivo es delegado al rey, para ser ejercido bajo su autoridad por ministros y otros agentes responsables, de la forma en que será determinado más adelante. El Poder Judicial es delegado a los jueces electos temporalmente por el pueblo. ${ }^{148}$

Los constituyentes del 89 al 91 resolvieron el arduo problema de definir la noción de gobierno representativo, teniendo que enfrentar el obstáculo crítico consistente en que la representación no podía ser de los intereses o de las clases de interés, ni representación de cuerpos o de órdenes, ni mandatos. Tuvieron que hacer la redefinición de la representación. Esta no tenía por objeto principal, para ellos, trasmitir una voluntad, reproducir una cualidad o expresar una caracterización, sino que su función sería la de organizar la voluntad y a la persona nacionales. Así, la representación era el proceso constructivo por el cual la Nación, como totalidad irreductible, constituida sólo por el derecho natural, podía actuar y hablar. De esta forma, la representación no era (como para Rousseau) un obstáculo para el mantenimiento

148 Para una mejor comprensión de los términos usados, habría que distinguir "Poder" entendido como órgano, de "poder" entendido como facultad o competencia. Es por ello que en el primer sentido se usan mayúsculas y en el segundo minúsculas. 
Este libro forma parte del acervo de la Biblioteca Jurídica Virtual del Instituto de Investigaciones Jurídicas de la UNAM

de la soberanía general. Al contrario, era la condición práctica de su ejercicio. ${ }^{149}$

\section{El sistema representativo y el poder comitente}

La idea de sistema representativo, elaborada por Sieyès, la iría a vincular con otra que es esencial a todo lo largo de su obra y que se debe tomar como punto de partida para reconstruir, desde el punto de vista orgánico, todo su sistema, "la autoridad viene de arriba y la confianza viene de abajo". En efecto, esta idea es un principio que Sieyès vincula con el régimen representativo y que a manera de hilo conductor atraviesa su teoría constitucional y política, ya que:

...La acción política - dice - en el sistema representativo, se divide en dos grandes partes: la acción ascendente y la acción descendente. La primera abarca todos los actos por los cuales el pueblo nombra inmediata o mediatamente a sus diversas representaciones, a las que encarga simplemente su concurso para solicitar o hacer la ley, o bien, para servirla en su ejecución una vez que ha sido promulgada. La segunda abarca todos los actos mediante los cuales esos diversos representantes se dedican a forjar la ley o a servirla. ${ }^{150}$

Hecha la distinción entre "poder constituyente" y "poderes constituidos" y a partir de las ideas anteriores, Sieyès esbozó su importante idea sobre el "poder comitente": "...el pueblo debe limitarse a ejercer por él mismo únicamente el Poder Comitente, es decir, debe limitarse a escoger y delegar a las personas que ejercerán sus derechos reales comenzando por el dere-

149 Rosanvallon, Pierre, "Les doctrinaires et la question du gouvernement representative", The French Revolution and the Creation of Modern Political Culture, Oxford, Pergamon Press, 1989, vol. III: The Transformation of Political Culture, editado por Furet-Ozouf, p. 515.

150 Sieyès, Emmanuel-Joseph, "Opinión de Sieyès...," op. cit., p. 241. 
Este libro forma parte del acervo de la Biblioteca Jurídica Virtual del Instituto de Investigaciones Jurídicas de la UNAM

cho (excepcional) de constituir el establecimiento público (Poder Constituyente)...". ${ }^{151}$

Por su parte, Pasquino desprende de aquí un serie de ideas que merecen ser retenidas:

- En el poder comitente se sitúa la influencia de la ciudadanía sobre sus representantes.

- Es la única forma de poder que está verdaderamente atribuida a la totalidad de los ciudadanos activos.

- Los poderes Legislativo y Ejecutivo, poderes constituidos, tienen por objeto la confección y aplicación de la ley; en cambio, la función del poder constituyente consiste en la instalación del conjunto de reglas - la Constituciónque rigen el establecimiento político de una nación. Por su parte, el poder comitente tiene como tarea garantizar, por medio de un mecanismo de autorización que viene de abajo, la legitimación, es decir, el carácter obligatorio de las órdenes que emiten los otros poderes.

- El poder constituyente y los poderes constituidos son ejercidos siempre por representantes. En cambio, el pueblo entendido como el conjunto singulatim de los ciudadanos activos, es titular y ejerce el poder comitente.

- De todo esto se desprende que el pueblo - considerado como ciudadanos ut singuli o en su totalidad - no tiene el derecho de ejercer inmediatamente los poderes constituyente y constituidos, que son confiados a sus representantes. Pero como contrapartida, estos poderes no pueden ser ejercidos legítimamente sin autorización de abajo, ni pueden ser ejercidos sin comisión ni procuración. ${ }^{152}$

El golpe teórico de Sieyès - dice Botana - invirtió los términos de la representación tradicional y ubicó de raíz la representación moderna en la voluntad individual y en la escala ascendente

151 Pasquino, Pascuale, "Emmanuel Sieyès, Benjamin Constant...”, cit., p. 226.

152 Ibidem, pp. 226 y 227. 
Este libro forma parte del acervo de la Biblioteca Jurídica Virtual del Instituto de Investigaciones Jurídicas de la UNAM

que de ella provenía: en efecto, el individuo elegía de abajo hacia arriba. Él sólo ponía en marcha el dispositivo que permitiría convertir las razones individuales dispersas en la sociedad en una razón pública capaz de representarlas y gobernarlas. ${ }^{153}$

\section{Voluntad general, voluntad de todos y gobierno representativo}

Una cuestión no resuelta en la teoría por Rousseau, residía en la diferenciación entre "voluntad general y voluntad de todos". Sieyès intentó dar su propia respuesta y explicación, vinculando el problema con el gobierno representativo, por lo que obtuvo una explicación esclarecedora de la mecánica de cómo opera este tipo de gobierno.

Empezó por plantear los prolegómenos de la vida en sociedad. Para ello, adoptó el punto de vista de Rousseau; es decir, las instituciones políticas sobre todo las relaciones entre gobernantes y gobernados se abordaban en términos de su legitimidad, lo que implicaba remontarse a una primera convención, al acto por el cual un pueblo es un pueblo:154 “...para satisfacer las necesidades comunes es preciso la voluntad común. Esa voluntad debe ser, naturalmente, el producto general de todas las voluntades particulares...". Ahora bien, esa voluntad común, igual a la voluntad de todos, sólo parecía ser necesaria en Sieyès para el acto de celebración del contrato originario y fundacional de la sociedad: “...y sin duda, la primera voluntad común de un número de hombres que se supone se reúnen en sociedad política es, exactamente la suma

153 Botana, Natalio R., "Comentarios finales", en Annino, Antonio (coord.), Historia de las elecciones en Iberoamérica, siglo XIX. De la formación del espacio nacional, Buenos Aires, Fondo de Cultura Económica, 1995, p. 471.

154 Baczko, Bronislaw, "Le contrat social des françaises: Sieyès et Rousseau", The French Revolution and the Creation of Modern Political Culture, Oxford, Pergamon Press, 1987, vol. I: The Political Culture of the Old Regime, editado por Baker, K. M., p. 495. 
Este libro forma parte del acervo de la Biblioteca Jurídica Virtual del Instituto de Investigaciones Jurídicas de la UNAM

de todas las voluntades individuales...". Mas, inmediatamente procedió a señalar la imposibilidad de exigir la voluntad de todos en los subsecuentes actos de la vida social: “...pero, para el futuro, esto significa renunciar a la posibilidad de desear en común; será la disolución de una unión exigir que la voluntad común sea siempre esa suma precisa de todas las voluntades...". Apeló, entonces, a la necesidad de convenir en la ley de la mayoría para poder gobernar a la sociedad:

...es necesario, pues, resolverse a reconocer todos los caracteres de la voluntad común en una voluntad convenida y no creer que, en una convención semejante, la sociedad no esté gobernada en el fondo más que por una voluntad incompleta. Todo ciudadano, por su acto de unión, contrae el compromiso constante de reconocerse ligado al punto de vista de la mayoría; aunque su voluntad particular pertenezca a la minoría. ${ }^{155}$

Con esta feliz fórmula resolvería el arduo problema político de la legitimidad de las formas de decisión en el gobierno representativo, pues se logra transparentar que en la voluntad de la mayoría de los miembros de una sociedad todos ellos se vean reflejados, porque todos - los que estuvieron a favor, los que se abstuvieron y hasta los que estuvieron en contra- contribuyeron a formar esa voluntad común.

\section{La idea de soberanía, forma de gobierno y naturaleza de la relación que une a electores y a elegidos}

Rousseau postuló la idea de que la soberanía residía a título inalienable y por tanto, intransferiblemente en el pueblo, lo que implicaba que cada miembro del soberano participaba de

155 Sieyès, Emmanuel-Joseph, "Consideraciones sobre los medios de ejecución de los cuales los representantes de Francia podrán disponer en 1789”, en Pantoja Morán, David (comp.), Escritos políticos de Sieyès, México, Fondo de Cultura Económica, 1993, p. 68. Las cursivas son mías. 
Este libro forma parte del acervo de la Biblioteca Jurídica Virtual del Instituto de Investigaciones Jurídicas de la UNAM

una fracción de la soberanía y, no pudiéndose expresar directamente cada copartícipe de la soberanía, debido a la extensión de los Estados modernos, los diputados electos por el pueblo, en esas condiciones, no podían ser sino comisionados de los electores mismos. Así, los elegidos no podían tener el poder de querer y decidir por la cuenta y en lugar de quienes los habían elegido. De aquí dedujo Rousseau que los electos por los ciudadanos no tenían ningún poder propio y no podían decidir soberanamente nada por ellos mismos, por tal razón repugnaba la representación política, en el sentido como la entendió la Asamblea Constituyente del 89 al 91: “...los diputados del pueblo, afirmaba, no son, entonces, ni pueden ser, sus representantes, no son más que sus comisarios...". ${ }^{156}$ Esto implicaba que dichos comisarios eran mandatarios puros, en el sentido de lo que exige el derecho civil, colocados bajo la dependencia de sus comitentes y subordinados a la voluntad popular, única entidad con posibilidades de hacer acto de soberanía.

Algunas consecuencias prácticas más se pueden desprender de la idea rousseauniana de la soberanía popular. Por una parte, conducía a la adopción del "mandato imperativo", por cuanto que el diputado al cuerpo legislativo nada podía emprender por su propia iniciativa, sino que siendo un simple "mandatario" debía actuar y votar en las asambleas, según "instrucciones imperativas" recibidas de sus electores. Por otra parte, su posición iba de la mano con la necesidad de la ratificación popular en materia legislativa. Efectivamente, para Rousseau, los diputados "no pueden concluir nada definitivamente", puesto que "toda ley que el pueblo en persona no ha ratificado es nula; no es una ley". ${ }^{157} \mathrm{Y}$ es que Rousseau, muy a su pesar, admitía el gobierno representativo, pero sólo bajo la condición de que paralelamente existieran mecanismos de democracia directa.

La idea de soberanía nacional, asociada a la adopción de la forma representativa de gobierno, conduciría a una concepción

156 Rousseau, Jean-Jacques, op. cit., p. 307.

157 Idem. 
Este libro forma parte del acervo de la Biblioteca Jurídica Virtual del Instituto de Investigaciones Jurídicas de la UNAM

de la relación entre electos y elegidos de naturaleza y alcances diferentes a los concebidos por Rousseau, "...la comunidad que decide dar más confianza a sus mandatarios les otorga poder a efecto de que se reúnan, deliberen y se pongan de acuerdo a fin de que quieran en común y entonces, en vez de simples votos, tienen verdaderos representantes...". 158

Así, se puntualizaba que la ciudadanía en su totalidad no daba "instrucciones" a sus elegidos, sino que les otorgaba su "confianza", para que en su nombre y representación quisieran en común, conforme a la voluntad nacional. Se trataba, entonces, de un "mandato representativo" y no de un "mandato imperativo". El cuerpo electoral no establecía delegados, sino representantes que libremente expresaban una voluntad que se reputaba como la voluntad de la Nación.

Por otra parte, al establecer representantes en ejercicio de su libertad, la Nación otorgaba una "procuración libre"; no establecía un compromiso ni un pacto de sumisión, "...y no hablamos de un pretendido contrato entre los pueblos y un amo, para lo cual los primeros se despojarían para siempre del derecho de querer por un primer acto de su voluntad. La comunidad no puede, más que un particular, renunciar a la facultad de deliberar y de querer para su propio interés...". ${ }^{159}$

Por lo que, para Sieyès: "...la misión de los representantes no puede nunca ser una "enajenación". Esta misión es esencialmente "libre", constantemente "revocable" y "limitada", según la voluntad de los electores, tanto por el tiempo como por la naturaleza de los asuntos...". ${ }^{160}$

158 Sieyès, Emmanuel-Joseph, "Consideraciones sobre los medios...," cit., p. 69. Las cursivas son mías.

159 Ibidem, p. 70.

160 Ibidem, p. 69. Las cursivas son mías. Al introducir el elemento de la "revocabilidad", Sieyès iría a tomar una posición diferente a la que ulteriormente sería aprobada por la Asamblea Constituyente en la Constitución que, como veremos, adoptó la idea del mandato representativo puro. Por esta única razón y, sin más argumentos, Clavreul sostiene que la influencia de Sieyès sobre las 
Este libro forma parte del acervo de la Biblioteca Jurídica Virtual del Instituto de Investigaciones Jurídicas de la UNAM

Con una cuestión más, remataría Sieyès la arquitectura armoniosa de su construcción teórica sobre la representación, al dilucidar la cuestión de si los diputados representaban a los electores singularmente considerados, en particular a los del distrito en que habían sido electos, o si representaban a su totalidad indivisible: la nación. Su argumentación la fundó en el grave inconveniente político consistente en que de representar ciudadanos e intereses particularizados, los diputados no podrían formar una voluntad común; entonces, optó porque la representación fuera de la totalidad. He aquí el argumento:

...parece ser que cada distrito nombra separadamente a sus representantes y no concurren a elegir a los de las otras divisiones; ningún distrito, siguiendo nuestros principios, podrá reconocer por ley más que aquélla que es su obra, no precisamente por el cuerpo entero de sus representantes, sino de la mayoría de los representantes particulares del distrito; en consecuencia, cada división tendrá veto, y se sabe que con un derecho de esta naturaleza se terminará por hacer imposible al cuerpo legislativo el ejercicio de sus funciones. Nada más verdadero: un derecho como este sería antipolítico, no se le puede reconocer y es necesario, al contrario, tener por máxima que cada diputado representa a la totalidad de la asociación... ${ }^{161}$

Esta misma cuestión la apuntaba en otro ensayo de la siguiente manera: “...el diputado de un bailiazgo es inmediatamente escogido por su bailiazgo, pero mediatamente es electo por la totalidad de los bailiazgos. He aquí porqué todo diputado es representante de la Nación entera. Sin esto, habría entre los diputados una desigualdad política que nada podría justificar, y la minoría podría hacer la ley a la mayoría, tal como lo he demostrado en otra parte". ${ }^{162}$

decisiones de la Asamblea no fueron tan importantes como la mayor parte de la doctrina lo afirma. Véase Clavreul, Colette, "Sieyès et la genése...," cit.

161 Sieyès, Emmanuel-Joseph, "Consideraciones sobre los medios...", cit., p. 69 .

162 Sieyès, Emmanuel-Joseph, "Palabras del abate Sieyès...”, cit., p. 208. 
Este libro forma parte del acervo de la Biblioteca Jurídica Virtual del Instituto de Investigaciones Jurídicas de la UNAM

La regla de que los diputados representaban a la Nación, ideada por Sieyès y adoptada después por el constitucionalismo francés, significaba que estos representaban no a la totalidad de los ciudadanos considerados individualmente, sino a su colectividad "indivisible" y "extraindividual". Esto no significaba, como bien lo aclara Carré de Malberg, que cada diputado representara (a más de sus electores) a los de otros distritos electorales en que la Nación estaba dividida, pues no tendría sentido desde el punto de vista jurídico. En efecto, si el diputado representara a los electores considerados individualmente no podría representar sino a aquéllos que lo habían elegido, puesto que al no haberse entablado relación alguna con los electores fuera de su circunscripción, no podía ser su representante. Entonces, los diputados no representaban circunscripciones electorales, ni ciudadanos en tanto que tales y, por ello, ninguna suma de individuos ut singuli, sino que representaban a la universalidad unificada de la Nación y distinta de los individuos o grupos que la componían. ${ }^{163}$

Por supuesto que esta idea tenía el propósito político de evidenciar la naturaleza diferente que separaba a la composición de los Estados Generales del Ancien Régime respecto de la Asamblea Nacional y sin duda alguna iría a modificar de manera radical la idea de representación en el derecho público francés. Tres son estas diferencias esenciales: a) el diputado deja de ser el representante de la corporación o cuerpo de ciudadanos que lo eligió, para convertirse en representante de toda la nación; b) la extensión de las facultades del diputado en las relaciones con sus electores es modificada: esta nueva concepción de representación excluye al mandato imperativo, pues, aunque el diputado sea electo dentro de una circunscripción electoral, una vez recibida la investidura, los ciudadanos que conforman la circunscripción en cierta medida dejan de ser el fundamento de sus poderes o facultades y el diputado permanece independiente de ellas durante el tiempo que dure la legislatura, y c) los Estados Genera-

163 Carré de Malberg, Raymond, Contribution á la Théorie..., pp. 223 y 224. 
Este libro forma parte del acervo de la Biblioteca Jurídica Virtual del Instituto de Investigaciones Jurídicas de la UNAM

les del Ancien Régime carecían de poder de decisión soberana y únicamente planteaban lo que sus estamentos les indicaban. Por lo contrario, las nuevas asambleas, constituidas en adelante en Asamblea Nacional, expresarían directa y soberanamente la voluntad de la nación. ${ }^{164}$

Finalmente, la idea sería incorporada en el artículo 7o., de la sección III, capítulo I, título III de la Constitución de 1791: "los representantes nombrados en los departamentos no serán representantes de un departamento particular, sino de la Nación entera y no les podrá ser dado ningún mandato".

\section{La idea de soberania y la concepción del sufragio}

La idea de soberanía popular conduciría a Rousseau a concebir al sufragio como un derecho, ya que suponía al ciudadano como un detentador de una fracción proporcional de la soberanía, por lo que cada miembro contratante del pacto social era un copartícipe individual de la autoridad soberana. En efecto, si como hemos visto en un pasaje citado de su obra, parte de la hipótesis que un "Estado está compuesto por diez mil ciudadanos... cada miembro del Estado no tiene por su parte sino la diez milésima parte de la autoridad soberana...", ${ }^{165}$ entonces se deduce que el soberano es la suma numérica de las soberanías individuales.

Rousseau también asumía como suya la consideración de los miembros individuales que constituían al pueblo, como la fuente originaria de donde emanaban los poderes públicos, de lo que resultaba que "los comisarios" que ejercían esos poderes y competencias efectivamente debían recibir tal investidura de la totalidad de quienes integraban el soberano.

De todo esto se puede concluir que, si para Rousseau, todos los ciudadanos tenían un derecho igual a formar la voluntad ge-

164 Ibidem, pp. 239, 247 y 262.

165 Rousseau, Jean-Jacques, op. cit., p. 254. 
Este libro forma parte del acervo de la Biblioteca Jurídica Virtual del Instituto de Investigaciones Jurídicas de la UNAM

neral, a constituir los poderes públicos y a participar en el ejercicio de la potestad pública, invistiendo a sus comisarios, el sufragio no sólo era un derecho natural, inherente a la calidad de miembro del Estado anterior a la Constitución estatal y fundado en su definición de soberanía, sino que este derecho debía ser universal, igual para todos y que no estuviera sometido a ninguna condición restrictiva, de cualquier naturaleza que fuera, en su disfrute. ${ }^{166}$

Sin embargo, la idea que finalmente se iría a imponer en el derecho público francés a este respecto no fue la consecuencia de la idea de soberanía popular de Rousseau, sino la que se desprende de la idea de soberanía nacional y que se originó en la Asamblea Constituyente del 79 al 81.

Para la doctrina que se fundaba en la idea de soberanía nacional, la Nación - persona moral, colectiva - se distinguía de los individuos que la componían y fue a ella, en su integridad indivisible, a quien se le reconoció la titularidad de la soberanía y no a los individuos. Como ya ha sido indicado, esta idea iría a ser recogida tanto en la Declaración de Derechos del Hombre y del Ciudadano de 1789 como en la Constitución de 1791, a la que sirve de preámbulo. Sus respectivos artículos 3o. y 1o. del título III, coinciden en reconocer a la nación como titular de la soberanía, con los atributos de ser una, indivisible, inalienable e imprescriptible y en negar a cualquier cuerpo, individuo o sección del pueblo la posibilidad de ejercer autoridad que no emane expresamente de ella o de atribuirse su ejercicio.

La doctrina que atribuía la soberanía a la nación, consecuentemente, no consideraba al voto como un derecho, pues la única representable era la nación, quien era la única también que tenía derecho a estar representada y, no siendo un derecho, el voto, no tenía por qué ser universal. La consecuencia única que se desprendía de la adopción del principio de soberanía nacional era

166 Véanse Carré de Malberg, Raymond, Contribution á la Théorie..., pp. 424 y 425; Duguit, Leon, Traité de Droit Constitutionnel, París, Ancienne Librairie Fontemoing, 1921, t. II, p. 443. 
Este libro forma parte del acervo de la Biblioteca Jurídica Virtual del Instituto de Investigaciones Jurídicas de la UNAM

que había que encontrar el mejor sistema para extraer la voluntad de la nación. ${ }^{167}$

La tarea del legislador, bajo estos presupuestos, sería la de determinar las condiciones más favorables para obtener la voluntad nacional, señalando los requisitos y la mecánica necesarios para designar a las personas encargadas de expresar esta voluntad. De esta forma, el voto era una "función" creada por la constitución, consistente en el procedimiento adecuado para extraer y expresar la voluntad nacional. Ya que si de acuerdo al poder nacional mismo, entonces cuando el ciudadano sufragaba y ejercía el poder electoral, dicho poder no podía ser considerado como una delegación del poder mismo de la nación. El elector devenía, de este modo, funcionario o agente del poder nacional. Por su parte, la Nación, única soberana, era dueña de determinar por medio de su Constitución, las condiciones bajo las cuales otorgaba a sus miembros el poder de sufragar en su nombre y por su cuenta.

De esta forma fue entendido el sufragio en el seno de la Asamblea Constituyente e incorporado en la Constitución de 1791, cuyo texto definitivo - a decir de Duguit - fue adoptado bajo el dictamen general formulado por Thouret. ${ }^{168}$ Algunas intervenciones sobre este debate pueden arrojar más luz. El propio Thouret, en la sesión del 11 de agosto de 1791, afirmó: "la calidad de elector está fundada sobre una «comisión pública» de la que la potestad pública del país tiene el derecho de regular la delegación". En la misma sesión, Barnave sostuvo que: "la cualidad de elector no es más que «función pública», a la que nadie tiene «derecho», que la sociedad otorga tal como se lo prescribe su interés: la función de elector no es un derecho". ${ }^{169}$

El debate sobre las modalidades para poder votar y ser votado fue el más apasionado de la Asamblea Constituyente. Aunque esta discusión empezó en 1789, existen evidencias de que se prolongó hasta 1791. En particular, fue motivo de una polémica

167 Ibidem, t. I, p. 443.

168 Ibidem, t. II, p. 444.

169 Ibidem, t. II, pp. 443 y 444. 
Este libro forma parte del acervo de la Biblioteca Jurídica Virtual del Instituto de Investigaciones Jurídicas de la UNAM

viva la determinación del límite en la contribución impositiva propuesto - fijado en un marco de plata - como requisito para ser elegible.

Un miembro de la comisión redactora de la Constitución propuso se exigiera una contribución igual a un marco de plata para ser elegible en calidad de representante a la Asamblea Nacional y este hecho suscitó la discusión. Pétion de Villenueve preguntaba a la Asamblea si debía retirarse la confianza a aquellos ciudadanos, a los que ya se les había otorgado por sus talentos, por el hecho de carecer de fortuna. Thibault señaló que de admitirse el requisito, se excluiría a gran número de ciudadanos y, sobre todo, a los eclesiásticos. Un miembro de la Asamblea no identificado solicitó se agregaran como elegibles a los propietarios de fundos territoriales y Ramel-Nogaret planteó la excepción de aquellos hijos de familia que pagaran el impuesto. El diputado Cazalès propuso se exigiera una propiedad territorial equivalente a mil doscientas libras. Barère de Vieuzac, a partir de estas propuestas, hizo la reflexión siguiente:

...vosotros estáis colocados entre los extremos ¿No admitís más que propietarios? Herís los derechos de otros ciudadanos interesados en la formación de la ley ¿Admitís hombres sin propiedad? Libráis al Estado y a las contribuciones a los hombres menos atados a su patria. En fin, si exigís una fuerte contribución, como la del marco de plata, alejáis de la Asamblea Nacional a los dos tercios de los habitantes del reino ¿Qué devendrán los artistas, las gentes de letras, las personas útiles dedicadas a la instrucción y esta clase tan preciosa, tan necesaria de los agricultores que no hay que perder de vista en la constitución de una Nación agrícola? ¿No es evidentemente substituirles por la aristocracia de los ricos?...

Por su parte, Target insistiría que:

...los diecinueve vigésimos de la Nación no poseen ninguna propiedad; así exigiendo una, excluís a la casi totalidad de los fran- 
Este libro forma parte del acervo de la Biblioteca Jurídica Virtual del Instituto de Investigaciones Jurídicas de la UNAM

ceses: en Inglaterra, al contrario, el más gran número es propietario; por otra parte, la fuente de exceso que se os ha indicado se encuentra en la feudalidad que aquí todavía está viva. Si imitáis este funesto ejemplo, la ventaja de fortuna dará nacimiento a una aristocracia y restableceréis las distinciones que habéis querido destruir... Pison du Galand propuso que la condición de propietario se expresara así: “...y poseer cualquier propiedad territorial". Por lo que Prieur pidió se substituyera el marco de plata por la confianza.

Por un error de procedimiento en el planteamiento y en la votación se aprobó que además de la contribución del marco de plata, se exigiera tener cualquier propiedad territorial. Varios oradores como Mirabeau y el abate Gregoire, entre otros subieron a la tribuna a reclamar los errores procedimentales cometidos. En vista de los problemas suscitados, la Asamblea decidió dejar esta discusión suspendida hasta nueva sesión. ${ }^{170}$

$\mathrm{Al}$ contrario de Inglaterra, en Francia el ciudadano moderno emergió abruptamente, a partir de una gran ruptura. Durante la Revolución, el ciudadano propietario no constituyó un verdadero modelo para pensar en la ciudadanía, aunque durante el siglo XVIII hubiera sido un referente por un momento. Y es que la caída del absolutismo tuvo como condición lógica la igualdad política de los individuos, misma que además fue imperativo sociológico de la destrucción del universo de los privilegios y de las corporaciones estamentales. Por consiguiente, Francia ingresó súbitamente al sufragio universal, pues la democracia se impuso, desde el inicio de la Revolución, como condición para la realización de una sociedad en libertad. Sólo que esto no ocurrió sin contradicciones y aún sin regresiones. Paralelamente a la irrupción del individuo-soberano en la esfera política, subsistía la cultura política del liberalismo del Siglo de las Luces, que veía en el gobierno de los más capaces la condición del progreso y de

170 Cfr. "Débat sur le marc d'argent (sesión del 29 de octubre de 1789)", en Furet François y Halévi, Ran, La Monarchie..., cit., pp. 418-422. 
Este libro forma parte del acervo de la Biblioteca Jurídica Virtual del Instituto de Investigaciones Jurídicas de la UNAM

la libertad. La Revolución no supo resolver esta contradicción con que inauguró su vida democrática. ${ }^{171}$

El rechazo a "la dictadura de las mayorías" no está excluido como trasfondo de esta doctrina. El liberalismo político era contrario a "la tiranía de las urnas" y el reconocimiento del voto como derecho, en buena lógica, conducía a concederlo de manera universal, directo e igualitario. La idea de soberanía nacional proporcionaba, en cambio, el argumento teórico para matizarlo: si del principio de soberanía nacional se desprendía que el derecho a sufragar y a la representación pertenecía no a los ciudadanos considerados individualmente, sino a la totalidad indivisible de la nación, entonces, el voto no era un derecho y, si no lo era, se podía restringir.

En el siglo XVIII, la distancia entre el pueblo y las élites era enorme no sólo cultural o económicamente, sino que también era antropológica y, en consecuencia, la igualdad política era inconcebible. Sin embargo, en poco tiempo se operó un cambio en la percepción de este abismo social, que hizo posible el advenimiento de la ciudadanía. Sieyès, nos dice Rosanvallon, es una buena pista para entender este cambio, que se operó no sin perplejidades ni prejuicios. ${ }^{172}$

$\mathrm{Al}$ inicio de la década de los setenta, cuando observaba a los que se dedicaban a trabajos pesados, no veía en ellos más que una multitud inmensa de "instrumentos bípedos", sin libertad y moral, que difícilmente podían ser llamados hombres, incapaces de formar parte de la sociedad, por incivilizados. Pero esta representación social fue trastocada, merced a la teorización que hizo de su rechazo a los privilegios. El enfrentamiento con el privilegiado, enemigo social emblemático, lo condujo a integrar al pueblo en un bloque sólido, el Tercer Estado, derrumbando el muro de las separaciones sociales. ${ }^{173}$

171 Rosanvallon, Pierre, La consagración del ciudadano..., cit., pp. 34 y 35.

172 Ibidem, pp. 56 y 57.

173 Ibidem, p. 58. 
Este libro forma parte del acervo de la Biblioteca Jurídica Virtual del Instituto de Investigaciones Jurídicas de la UNAM

Ahora bien, la igualdad social moderna no implicaba para Sieyès la negación absoluta de toda separación, incluso si ésta se oponía en esencia a la separación tajante entre ciudadanos y esclavos que se imponía en las sociedades antiguas. Aunque, la libertad y la igualdad encontraban un punto de anclaje común en el reconocimiento de los derechos del hombre, para Sieyès, era ilusorio creer que se pudiera universalizar de igual manera la antigua figura del ciudadano. Apeló entonces a una división, que era móvil y se insertaba en una perspectiva nueva: la división del trabajo. Esta ya no tenía el sentido de radical exclusión de la dicotomía hombre libre-esclavo, sino que era puramente funcional y proporcionaba la ventaja de ser provechosa para el conjunto de la sociedad. Como se ha visto antes, fue el fundamento de su concepción sobre el Estado representativo moderno. ${ }^{174}$

Una etapa nueva se abrió en su pensamiento cuando elaboró la distinción entre ciudadanos activos y ciudadanos pasivos, y es que la evolución rápida de los acontecimientos le llevaron a repensar la división social, aunque continuaba a concebir la esfera política a partir de la división del trabajo. Así, cuando observaba a la nueva sociedad, que emergía ante sus ojos y que hacía que las naciones europeas parecieran vastos talleres, impulsados por el ansia de la producción y el consumo, se vio obligado a no ver en los hombres sino máquinas de trabajo. No obstante, a éstos no les podía negar la calidad de ciudadanos y los derechos de civismo, así fuera una multitud carente de instrucción y absorta por completo por el trabajo, puesto que también obedecían a la ley y concurrían a crearla. Con todo, los obstáculos se mantenían, se preguntaba, ¿cómo conceder la calidad de ciudadanos a los mendigos, a los vagabundos voluntarios o a los que carecían de domicilio? Fue para resolver esta contradicción que concibió la distinción entre ciudadanos activos y ciudadanos pasivos. Si bien todos los individuos debían ser igualmente ciudadanos, se hacía necesario trazar una diferenciación que dividiera esta equivalencia. ${ }^{175}$

174 Ibidem, pp. 60 y 61.

175 Ibidem, pp. 63 y 64. 
Este libro forma parte del acervo de la Biblioteca Jurídica Virtual del Instituto de Investigaciones Jurídicas de la UNAM

La justificación teórica para fundar las restricciones al ejercicio del sufragio, la había dado en temprana hora Sieyès con lo siguiente:

...todos los habitantes de un país deben disfrutar de los derechos del ciudadano pasivo: todos tienen derecho a la protección de su persona, de su propiedad, de su libertad, etc.; pero no todos tienen derecho a desempeñar un papel activo en la formación de los poderes públicos; no todos son ciudadanos activos. Las mujeres, al menos en el estado actual, los niños, los extranjeros, y también los que no contribuyan en nada a sostener el establecimiento público, no deben influir activamente en la cosa pública. Todos pueden disfrutar de las conveniencias de la sociedad, pero solo aquéllos que contribuyen al establecimiento público son, por así decirlo, los verdaderos accionistas de la gran empresa social. Sólo ellos son los auténticos ciudadanos activos, los auténticos miembros de la asociación...176

En el mismo sentido, a propósito de la discusión sobre el veto, Mounier diría lo siguiente:

...La Comisión [la redactora de la Constitución] al indicar las cualidades que deben dar a los ciudadanos la facultad de ser electores y elegibles a la Cámara de Representantes, se ha visto obligada a pronunciarse entre dos inconvenientes que chocan en apariencia con la libertad natural. Es evidente que no se puede admitir a todos los ciudadanos indistintamente en el número de electores y elegibles; sería exponer la suerte del Estado en manos inexpertas, que consumarían rápidamente la ruina. Sería necesario, entonces, restringir el número de electores y no poner ningún límite a su elección, o dejar a todos los ciudadanos el derecho de elegir y trazarles reglas para dirigir su nominación... Todos los ciudadanos tienen el derecho de influir sobre el gobierno a menos por sus sufragios; deben ser aproximados a ello por la representación. Si vosotros exigís para los electores cualidades que limitan el

176 Sieyès, Emmanuel-Joseph, "Preliminar de la Constitución...", cit., pp. 183 y 184. 
Este libro forma parte del acervo de la Biblioteca Jurídica Virtual del Instituto de Investigaciones Jurídicas de la UNAM

número, convertiréis a todos aquéllos que serán excluidos ajenos a su patria, indiferentes sobre su libertad. Estas reflexiones han determinado a la Comisión a admitir entre los electores a todos aquéllos que paguen un impuesto directo igual al precio de tres jornadas de trabajo. Considerando que los electores no escogen por su interés solamente, sino por el de todo el imperio, creyó conveniente no declarar elegibles sino a aquéllos que posean una propiedad territorial. Es un homenaje rendido a la propiedad que completa la calidad de ciudadano. Es un medio más para hacer amar el campo; es un motivo para creer que el representante está por encima de la necesidad. Es poner un muy débil obstáculo a la libertad de escoger; pues todo hombre, juzgado digno de la confianza de un distrito por sus luces y por sus virtudes, podrá fácilmente procurarse cualquier propiedad, si el valor no está determinado. ${ }^{177}$

La Constitución de 1791 positivizó de manera expresa estas ideas. En efecto, el artículo 2o. del título III, capítulo I, sección II, de la Constitución de 1791 exigía, entre otras cualidades para ser ciudadano activo, la de pagar "una contribución directa igual al menos de tres jornadas de trabajo y presentar el comprobante de pago. No estar en estado de domesticidad, es decir, de servidor a jornal". Además, la misma opinión electoral de los ciudadanos activos se encontraba filtrada por la elección indirecta a dos grados, y el artículo 7o. del mismo título, capítulo y sección, exigía para ser elector en segundo grado, a más de las condiciones necesarias para ser ciudadano activo, "ser propietario o usufructuario de un bien valuado sobre los roles de contribución en un ingreso igual al valor local de...” (aquí variaba) ciento cincuenta a cuatrocientas jornadas de trabajo, según se tratara de ciudades de más o de menos de cien mil almas o de zonas rurales.

177 Mounier, "Discours de Mounier sur la sanction royale (5 de septiembre de 1789)," en Furet François y Halévi, Ran, La Monarchie..., cit., pp. 388 y 389. 
Este libro forma parte del acervo de la Biblioteca Jurídica Virtual del Instituto de Investigaciones Jurídicas de la UNAM

\section{Crítica a la doctrina que opone a la idea de soberanía popular a la de soberanía nacional}

La doctrina que opone a la idea de soberanía popular a la de soberanía nacional y que desprende consecuencias diferenciadas sobre las instituciones, según se adopte como principio una u otra - expresada en los apartados que anteceden - ha sido motivo de críticas, algunas de las cuales merecen ser mencionadas. ${ }^{178}$

En primer término, ha sido criticada desde el punto de vista lógico, porque se dice que la contraposición de la idea de soberanía popular a la de soberanía nacional tendría sentido si todas las Constituciones, o al menos todas las Constituciones de los sistemas representativos, estuvieran fundadas en uno u otro de tales principios, de manera que cada una fuera susceptible de entrar en uno u otro de los dos tipos, que ninguna pudiera ser considerada como perteneciente a los dos tipos al mismo tiempo, o estar fuera de clasificación. Todo lo cual no sucede, porque hay Constituciones numerosas que no pueden ser incluidas en la clasificación. Se argumenta que ni siquiera las Constituciones de la época revolucionaria encajan bien en la tipología, porque la Constitución de 1793, supuestamente fundada en la idea de soberanía popular, consagró el referéndum de labios para fuera y prohibió el mandato imperativo y la Constitución del año III, supuestamente basada en la idea de soberanía nacional, adoptó el sufragio universal.

La doctrina comentada comete un error histórico, se dice, cuando atribuye los dos principios a las Constituciones de la época revolucionaria. En realidad, los dos términos, pueblo y Nación, eran sinónimos en dicha época. No se hacía la distinción: nación - entidad abstracta y soberanía nacional un principio

178 Cfr. Bacot, Guillane, Carré de Malberg et l'origine de la distinction souveranité du peuple-souveranité nationale, París, Ed. CNRS, 1985. Aquí se toman algunas de las críticas de Troper, Michel, "La souveranité nacionales appartient au peuple. L'article 3 de la constitution de 1958", en Troper M. y Jaume L. (dirs.), 1789 et l'invention de la constitution, LGDJ-Bruylant, 1994, pp. 253-255. 
Este libro forma parte del acervo de la Biblioteca Jurídica Virtual del Instituto de Investigaciones Jurídicas de la UNAM

puramente negativo frente a pueblo - realidad concreta y soberanía popular principio positivo. La oposición entre la idea de soberanía popular y la de soberanía nacional no se construyó en la época revolucionaria, sino que fue concebida en el siglo XIX, por la teoría clásica del derecho público francés, particularmente por Carré de Malberg. No habiéndose construido durante el periodo revolucionario la teoría del sistema representativo, a partir del concepto abstracto de nación, sino que se concibió para justificar la participación del rey al ejercicio del Poder Legislativo y fundar así su calidad de representante, entonces, la teoría de la representación, dice esta crítica, no se desprendió del principio de soberanía nacional, sino que al contrario el principio de la soberanía nacional fue el que se desprendió de la teoría de la representación.

Reconociendo la existencia de ciertas excepciones menores, a la rigurosa aplicación de la regla, como las que señala Troper, no es menos verdad que la doctrina funciona con un acierto aceptable y es bastante funcional para construir con ella una tipología de las Constituciones que han sufrido la influencia francesa, como las latinoamericanas inmediatamente proclamadas después de los procesos de independencia de esos países.

\section{DisGUSIONES RELATIVAS A LA INGENIERÍA CONSTITUCIONAL}

\section{La ingeniería de la sanción real, el derecho de veto y el bicamarismo}

Una vez aprobados los dos textos fundamentales de la Revolución - los decretos del 4 y del 11 de agosto y la Declaración de Derechos del 26 de agosto - se planteó para la Asamblea un grave problema $\dot{i}$ Eran estos textos inmediatamente ejecutorios o se necesitaba la firma del rey? La mayoría de la Asamblea los con- 
Este libro forma parte del acervo de la Biblioteca Jurídica Virtual del Instituto de Investigaciones Jurídicas de la UNAM

sideraba como un producto de sus facultades constituyentes y, en consecuencia, por encima de la sanción real. El argumento ya lo había proporcionado Sieyès en su opúsculo “¿qué es el Tercer Estado?", donde demostraba que el poder constituyente de la nación era un atributo de la soberanía, que pertenecía al derecho natural y que no podía limitarse. La consecuencia que se desprendía de este principio era que un poder constituido no podría oponerse a la voluntad del poder constituyente. Por lo contrario, Luis XVI pensaba que el rey tenía poderes de arbitraje y, en consecuencia, estaba en capacidad de negar o conceder la autorización que los legitimara. Así, lo expresó al arzobispo de Arles: "no consentiré jamás en despojar a mi clero, a mi nobleza... No daré mi sanción a decretos que los despojarían". ${ }^{179}$

Este problema, que atañe de manera importante a la organización de los poderes y a las relaciones de éstos entre sí, provocaría las primeras fracturas en el interior del denominado "partido patriota". Solamente algunos meses después de haber incitado a los Estados Generales a la revuelta abierta, estos mismos hombres que abolieran los privilegios y aplaudieran la toma de la Bastilla, ya pretendían bloquear el mecanismo que ellos mismos habían echado a andar. Los acontecimientos habían rebasado a muchos nobles liberales, a muchos clérigos y a no pocos diputados moderados del Tercer Estado y esta coyuntura les brindaba las vías para encontrar la estabilización que ansiaban: dar al rey veto absoluto sobre las decisiones del Poder Legislativo y equilibrar a la Asamblea electa con un Senado hereditario, como lo habían hecho los ingleses.

Es a propósito de estas dos ideas que los que serían llamados "monarquistas" o "anglómanos", romperían con el grueso del partido patriótico. A los monarquistas los encabezaban Mounier, Malouet, Clermont-Tonnerre y Lally-Tollendal, y contaban con el apoyo de Neker. Se enfrentarían a Duport, Barnave, Lameth

179 Furet François y Richet, Denis, La Revolution..., cit., p. 92. 
Este libro forma parte del acervo de la Biblioteca Jurídica Virtual del Instituto de Investigaciones Jurídicas de la UNAM

y, de manera notable, Sieyès. A fines de agosto la ruptura sería irremediable. ${ }^{180}$

Este debate sobre el veto despertó enconos y pasiones, y fue seguido atentamente en París. La maniobra que coaligó a aristócratas y monárquicos por obtener el veto absoluto fue denunciada antes de que fuera realidad. La amenaza de una marcha hasta Versalles contribuyó seguramente a la derrota de esta iniciativa: "el veto - se dijo en una moción - no pertenece a un solo hombre, sino a veinticinco millones".

Barnave propuso el 2 de septiembre una posible salida política al conflicto, mediante una negociación en la que ambas partes obtendrían ganancias. Se aceptaría conceder la facultad de veto suspensivo al rey, durante dos legislaturas, si éste accedía a sancionar los decretos del 4 y del 11 de agosto. Neker dio garantías de que así sucedería y el 11 de septiembre, la Asamblea accedió, por 575 votos contra 325, a que se concediera al rey el veto suspensivo, no sin antes haber rechazado la noche anterior, la posibilidad de una segunda cámara por 849 votos contra 89 y más de 100 abstenciones de la derecha. ${ }^{181}$

No obstante, la discusión había sido riquísima y quizá por ser tan prematura, proporcionaría no pocos elementos para la elaboración posterior de los principios básicos de la organización del Estado. Entre otras cuestiones se dio pie para discutir la conveniencia del bicamarismo. Así, la coyuntura dio lugar a dos debates fundamentales sobre la ingeniería constitucional, enlazados cronológicamente.

180 Ibidem, p. 92.

181 Véanse Soboul, Albert, op. cit., pp. 172-175; Furet François y Richet, Denis, La Revolution..., cit., pp. 92 y 93. Por cierto, para paliar el desorden y la confusión en el debate, la Asamblea decidió organizarse en un ala derecha y una izquierda. A la derecha del presidente se colocarían los partidarios del veto y a la izquierda los contrarios a él. Esta es la historia del origen de la geometría política, tan conocida y manida en nuestros días. Cfr. Richet, Denis, "L'esprit de la constitution, 1789-1791", The French Revolution and the Creation of Modern Political Culture, Oxford, Pergamon Press, 1988, vol. II: The political culture of the French revolution (Ed. Colin Lucas), p. 65. 
Este libro forma parte del acervo de la Biblioteca Jurídica Virtual del Instituto de Investigaciones Jurídicas de la UNAM

Como le será evidente al lector, aconteció lo que tantas veces se repitió a lo largo del trabajo de la Asamblea: se mezcló en la discusión lo coyuntural - consistente en si se necesitaba o no la sanción real para los decretos del 4 y del 11 de agosto para la Declaración de Derechos - con lo estructural consistente en determinar si en la Constitución que estaba en proceso de redacción se iría o no a conceder al rey la facultad de veto.

En esta discusión será conveniente tener presente la diferencia de opinión que dividió a algunos autores en relación con el veto. Para unos, el derecho de veto constituía una excepción al principio de especialización y mantenían solamente que era indispensable para la independencia del órgano ejecutivo y, en consecuencia, para ellos, el veto sería la excepción que confirmaba la regla. Otros sostenían que la institución de la facultad de veto era conforme al principio de la especialización, al menos en la opinión de ciertos pensadores políticos del siglo XVIII. ${ }^{182}$

Los que sustentaban esta última interpretación se fundaban en la distinción que hizo Montesquieu entre la facultad de "estatuir" y la facultad de "impedir", 183 para disimular el hecho que el derecho de veto era una derogación al principio de separación de poderes. Según esta interpretación, Montesquieu habría pensado que la facultad de estatuir hacía de su titular sólo un legislador o un colegislador y la facultad de impedir era sólo un atributo de la "función ejecutiva", porque era un medio dado al órgano ejecutivo para "evitar la ejecución" de una ley ya formada. ${ }^{184}$

No obstante, esta posición no es muy convincente, según Troper, los autores del siglo XVIII, discípulos de Montesquieu, afirmaron en forma clara que consideraban el derecho de veto del rey de Inglaterra como una participación en la función legislativa.

182 Troper, Michel, La separation des pouvoirs et l'histoire constitutionnelle francaise, París, L.G.D.J., 1980, p. 25.

183 Montesquieu, 'L'Esprit des Lois et la querelle de l'Esprit des Lois. 17481750", en Oeuvres complètes, París, Ed. du Seuil, 1964. p. 588.

184 Troper, Michel, La separation..., cit., p. 25. 
Este libro forma parte del acervo de la Biblioteca Jurídica Virtual del Instituto de Investigaciones Jurídicas de la UNAM

Cita, entre otros, en primer término a Madison, ${ }^{185}$ quien expresó que en la Constitución inglesa el magistrado ejecutivo era parte integrante de la autoridad legislativa y a Blackstone quien, más explícitamente, diría que era altamente necesario para preservar el equilibrio de la Constitución que el Poder Ejecutivo pudiera ser una rama, sin ser la totalidad de la legislatura. De esta forma, la distinción entre la facultad de estatuir y la facultad de impedir de Montesquieu cobraba su verdadero sentido: no significaba que para Montesquieu aquél que no dispusiera más que del derecho de impedir no fuera coautor de la decisión, sino simplemente que el que impedía no podía hacer la ley por sí solo, que su consentimiento no era suficiente, aunque fuera necesario. ${ }^{186}$

Toda esta interpretación sería confirmada por un diputado, quien utilizaba una versión exacta de Blackstone y paráfrasis de Montesquieu para fundar su intervención: Lally-Tollendal — diputado de la nobleza y el más brillante intérprete del grupo monárquico - presentó una larga argumentación en la que se mezclaban no sólo las cuestiones del veto y del bicamarismo, sino otras más, por lo que trataremos de desagregarlas.

Señores, ¿debe el cuerpo legislativo estar compuesto de un solo Poder? ¿Cuáles serían la especie de acción y los diversos grados de influencia de las diferentes porciones del cuerpo legislativo, si estuviera dividido... En todas partes donde el Poder Legislativo está en una sola mano, en todas partes donde el Poder Ejecutivo está compartido entre varios, no puede existir la libertad. No hay necesidad de probar que los representantes de la Nación deben ser la primera porción del cuerpo legislativo. El todo pertenece originariamente a esta Nación. No hay ninguna potestad, no hay ninguna función pública que no emane de ella: ella ha podido y debido compartir; pero no ha podido ni debido despojarse enteramente... Sería igualmente superfluo buscar a establecer que el Rey deba ser una parte integrante del Poder Legislativo; nos

185 Hamilton, Madison, Jay, El Federalista, México, Fondo de Cultura Económica, 1957, pp. 311-316.

186 Troper, Michel, La separation..., cit., p. 26. 
Este libro forma parte del acervo de la Biblioteca Jurídica Virtual del Instituto de Investigaciones Jurídicas de la UNAM

cuesta trabajo creer que una sola duda pueda haber frente a esto; si la hubiere, la rechazaríamos con el razonamiento y los hechos. En cuanto al razonamiento, diríamos primero con los más hábiles publicistas [Blackstone] que, para mantener el equilibrio de la constitución es necesario que el Poder Ejecutivo sea una rama sin ser la totalidad del Poder Legislativo; que así como la unión entera de esos dos Poderes produciría la tiranía, su desunión absoluta la produciría igualmente... Diríamos que la necesidad de establecer un punto de unión entre Poder Legislativo y el Poder Ejecutivo, una vez reconocido, el Poder Legislativo como divisible por naturaleza y el Poder Ejecutivo indivisible por la suya, es, por consecuencia, a la totalidad de éste último que debe estar ligada una porción del primero; y agregaríamos que esta porción se restringiría al derecho de aprobar o de rechazar; y la iniciativa, es decir la propuesta, la discusión, la redacción de las leyes pertenecería exclusivamente a la Asamblea Nacional, la autoridad real no adquiriría por ello sino el medio de impedir el mal y no el de hacerlo... Es una verdad general e incontestable que hay en el corazón de todos los hombres una inclinación invencible hacia la dominación, que todo poder es vecino del abuso del poder y que hay que limitarlo para impedir que dañe... Es necesario a una fuerza activa oponer una fuerza activa. De otra parte no hay que dejar a esas dos fuerzas expuestas a estar perpetuamente enfrentada una a la otra. La desgracia de la sociedad entera sería el triste resultado de estas guerras continuas. De ahí se sigue la necesidad de balancear los Poderes, de dividir la potestad legislativa, y la necesidad de dividirla no en dos, sino en tres Poderes. Un Poder único acabará necesariamente por devorar todo. Dos se combatirán hasta que uno aplaste al otro. Pero tres se mantendrán en un perfecto equilibrio, si están combinados de tal manera que cuando dos luchen juntos, el tercero igualmente interesado en el mantenimiento de uno o de otro se una a aquél que está oprimido contra aquél que oprime y lleve la paz entre todos... Sería entonces de desear que el cuerpo legislativo estuviera compuesto de tres partes integrantes: 1. de los representantes de la Nación; 2. de un Senado; 3. de un Rey... Así, las tres formas de gobierno, encontrándose mezcladas y confundidas, producirían una que presentaría las ventajas de todas sin tener los inconvenientes de ninguna; y la Nación, habiendo delegado sus poderes en la im- 
Este libro forma parte del acervo de la Biblioteca Jurídica Virtual del Instituto de Investigaciones Jurídicas de la UNAM

posibilidad de ejercerlos ella misma, no teniendo nada que temer de ninguno de sus mandatarios, defendida por sus representantes contra la ambición de sus reyes, defendida por la prerrogativa real contra la ambición de sus representantes, defendida contra la envidia de unos y de otros por una magistratura escogida, no pagando más impuestos que aquéllos que ella hubiera dado la facultad de consentir, no conociendo más leyes que aquéllas que ella hubiera dado el poder de hacer, gozando pacíficamente de su libertad, de su propiedad, de su industria, sería la Nación más feliz del universo... ${ }^{187}$

Otra intervención digna de registrarse, por cuanto que introduce la idea del veto suspensivo, fue el discurso de Malouet, quien se expresó así:

Señores, ¿qué es la sanción real? ¿Debemos concederla? ¿Cómo debe estar determinada?... la sanción real es un derecho y una prerrogativa nacional conferida al jefe de la Nación por ella misma, para declarar y garantizar que una resolución de sus representantes sea o no la expresión de la voluntad general... El pueblo, señores, que quiere, que determina qué le es útil tener un Rey, que lo instituye como centro de todos los Poderes, como conservador de todos los derechos, tiene precauciones qué tomar para conservar en las manos de una sola autoridad a la que él le difiere, y para impedir que él no abuse de ella... Esta última intención es llenada, de la parte del pueblo, reservando a sus representantes el ejercicio del Poder Legislativo, y la vigilancia del Poder Ejecutivo. Pero el pueblo tiene igualmente interés en defender la autoridad real de todo asedio injusto de parte de sus representantes; ahora bien, esta intención del pueblo no puede ser llenada sino admitiendo al príncipe en el examen y en la sanción de las leyes, pues, si en los poderes delegados existe uno solo que le sea extraño y del cual fuera personalmente dependiente, sería un poder absoluto al cual la Nación, como su jefe, se encontraría sometida... La sanción real es, entonces, útil para la tranquilidad de la Nación;

187 Lally-Tollendal, "Discours de Lally-Tollendal sur l'organisation du Pouvoir Legislatif et la sanction royal (31 de agosto de 1789)", en Furet, François y Halévi, Ran, La Monarchie..., cit., pp. 345-349. 
Este libro forma parte del acervo de la Biblioteca Jurídica Virtual del Instituto de Investigaciones Jurídicas de la UNAM

es necesaria al monarca para dirigir pacíficamente la potestad pública; pero no es menos importante para la seguridad de los miembros del cuerpo legislativo... En cuanto a la naturaleza del veto, teniendo uno absoluto únicamente la Nación, el del Rey, en último análisis, no puede ser sino suspensivo; pues si el pueblo persiste en desear la ley propuesta, si encarga con perseverancia además a sus representantes de proponerla, el monarca no tiene ni derecho, ni medio de resistencia; pero los límites del veto real estando planteados para los príncipes, su expresión debe ser simple y absoluta, sin que sea necesario enunciar los motivos. ${ }^{188}$

También Mirabeau tendría una intervención importante al respecto. Empezó por hacer una distinción útil, que es detectable en otros contemporáneos, para fundar la correspondiente a los poderes Ejecutivo y Legislativo:

...dos poderes son necesarios a la existencia y a las funciones del cuerpo político: el de querer y el de actuar. Por el primero, la sociedad establece las reglas que la deben conducir al fin que ella se propone y que es incontestablemente el bien de todos. Por el segundo, estas reglas se ejecutan, y la fuerza pública sirve para hacer triunfar a la sociedad sobre los obstáculos que esta ejecución pudiera encontrar en la oposición de las voluntades individuales... En una gran Nación estos dos poderes no pueden ser ejercidos por ella misma; de ahí la necesidad de los representantes del pueblo para el ejercicio de la facultad de querer o de la potestad legislativa; de ahí también la necesidad de otra especie de representantes para el ejercicio de la facultad de actuar o de la potestad ejecutiva...

Distinguió, con pertinencia, la facultad de veto que se ejerce una vez que la Constitución ha sido establecida, de la pretensión infundada que algunos intentaban de que el rey pudiera negarse a conceder su sanción al ejercicio del poder constituyente:

188 Malouet, "Discours de Malouet sur la sanction royale (1 de septiembre de 1789)," en Furet, François y Halévi, Ran, La Monarchie..., cit., pp. 364-369. 
Este libro forma parte del acervo de la Biblioteca Jurídica Virtual del Instituto de Investigaciones Jurídicas de la UNAM

pienso que el derecho de suspender y aún de detener la acción del cuerpo legislativo debe pertenecer al Rey cuando la constitución ya esté hecha, y que se tratará solamente de mantenerla. Pero este derecho de detener, este veto no podría ejercerse cuando se trata de crear la constitución: no concibo como podría disputarse a un pueblo el derecho de darse a sí mismo la constitución por la cual desea estar gobernado en adelante...

Concluyó dando razones políticas plausibles para fundar el derecho de veto:

Todas estas objeciones desaparecen ante esta gran verdad, sin un derecho de resistencia en la mano del depositario de la fuerza pública esta fuerza podría a menudo ser reclamada y empleada a pesar de ella a ejecutar voluntades contrarias a la voluntad general... Primero, si el príncipe no tiene el veto, ¿quién impedirá a los representantes del pueblo prolongar y, poco después, eternizar su diputación?... Segundo, el veto, sea del príncipe sea de los diputados a la Asamblea Nacional, no tiene otra virtud que detener una propuesta: no puede, entonces, resultar de un veto, cualquiera que sea, una inacción del Poder Ejecutivo a este efecto. Tercero, el veto del príncipe puede, sin duda, oponerse a una buena ley; pero puede preservar de una mala, cuya posibilidad no podría ser puesta en duda... Suponed ahora el derecho de veto arrebatado al príncipe, y el príncipe obligado a sancionar una ley mala: no tendréis ya esperanza más que en una insurrección general, cuya salida más feliz sería probablemente más funesta para los indignos representantes del pueblo que la disolución de su asamblea... No armemos entonces al Rey contra el Poder Legislativo, haciéndole entrever un instante cualquiera donde se podría prescindir de su voluntad, y donde, por consecuencia no sería más que el ejecutor ciego y forzado. Sepamos ver que la Nación encontrará más seguridad y tranquilidad en las leyes expresamente consentidas por su jefe, que en las resoluciones donde él no tendrá parte alguna y que contrastarían con la potestad de la cual sería necesario revestirla, en todo caso. ${ }^{189}$

189 Mirabeau, "Discours de Mirabeau sur le droit de veto (1 de septiembre de 1789)", en Furet, François y Halévi, Ran, La Monarchie..., cit., pp. 369-378. 
Este libro forma parte del acervo de la Biblioteca Jurídica Virtual del Instituto de Investigaciones Jurídicas de la UNAM

Merced a un importante discurso, Petion dio a la izquierda de la Asamblea constituyente el mejor argumento democrático en favor de un veto suspensivo del rey, al hacer del desacuerdo eventual entre el Legislativo y el Ejecutivo la ocasión para un arbitraje por el pueblo mismo.

En efecto, como se verá, propuso un referéndum de arbitraje para dirimir la diferencia, en lugar de que el veto suspensivo diera lugar a una disolución:

Señores, cuando una ley propuesta por el cuerpo legislativo sea suspendida por el impedimento del Rey; cuando estas dos potencias se encuentren así en oposición, ¿tendrá la Nación la libertad de expresar su deseo preciso por el órgano de sus mandatarios, o bien su derecho se limitará a escoger a nuevos representantes a los cuales estará obligada de confiar mandatos ilimitados?... Pretenden que en una Nación numerosa no pudiendo todos reunirse para discutir los asuntos públicos, se encuentran forzados a escoger representantes para tratarlos y regularlos... Agregan que esta representación estando comandada por la ley imperiosa de la necesidad, los mandatarios deben gozar de la libertad más extendida; que sus comitentes deben someterse a sus decretos; que no tienen ninguna orden positiva a darles; que su poder se limita a elegirlos; que ahí habría el peligro más grande y la inconsecuencia más repulsiva a autorizar a cada distrito a manifestar su deseo particular y aislado. Que el representante de una provincia no pertenece a esta provincia; que es el hombre de la Nación; que no puede tener más que un mandato general, y una opinión que se forma en el seno mismo de la Asamblea... Yo me apuro en convenir que en todas las circunstancias ordinarias, se debe remitir a los representantes poderes ilimitados. Cuando parten de diferentes puntos del reino para reunirse y discutir en común objetos que no tienen nada de determinado, que no están ni previstos ni conocidos por sus comitentes, sería bizarro y absurdo encadenar sus voluntades por mandatos imperativos ¿Sobre qué recaerían sus decisiones absolutas?... ocupándose cada distrito separadamente de temas diversos, no se podría arribar a un resultado general sobre ninguno... Pero cambiad la tesis; suponed un punto fijo, pre- 
Este libro forma parte del acervo de la Biblioteca Jurídica Virtual del Instituto de Investigaciones Jurídicas de la UNAM

ciso sometido en el mismo momento a la discusión de las diferentes asambleas elementales, que pueda decidirse por una fórmula simple: yo no veo entonces por qué cada una de esas asambleas no podría encargar a sus representantes de la expresión de su deseo... ¿Por qué los pueblos se escogen representantes? Es que la dificultad de actuar por ellos mismos es casi siempre insuperable; pues si estos grandes cuerpos pudieran estar constituidos de manera a moverse fácilmente y con regularidad, los delegados serían inútiles; aún más diría yo, serían peligrosos... Sería necesario probar que, cuando un artículo de la ley es combatido y dudoso, que los Poderes no pueden conciliarse, es imposible a la Nación adoptar un partido entre estas pretensiones opuestas; ahora bien yo no percibo esta imposibilidad. La decisión de un diferendo semejante se presenta, al contrario, a mis ojos, como simple y fácil; se trata de un objeto fijo, conocido y aclarado por la discusión pública, sobre la cual las asambleas elementales se podrían pronunciar por la fórmula más precisa si o no, o si ellas lo quisieran mejor por éstas: adopto el impedimento o lo rechazo. Toda la Nación dividida así por grandes secciones se expresaría sin dificultad...

Una vez fundadas las ventajas y la viabilidad del referéndum de arbitraje, para dirimir los diferendos entre los poderes, se lanzó en contra de la pretensión de conceder al rey la facultad de disolver la Asamblea y de convocar a elecciones, como medio de resolución del conflicto:

Se propone una especie de llamado que no puedo admitir; se quiere que en el instante en que el Rey haya opuesto su veto, la Asamblea de Representantes sea disuelta. Se agrega que si estos representantes son de nuevo electos, el veto no será eliminado; que si los comitentes envían a otros, este signo de desaprobación de la conducta de los primeros anunciaría la confirmación del veto. Así la Nación estará reducida a expresar indirectamente su deseo por la selección de sus delegados... Enseguida, no sé cómo se puede dar al Rey semejante exceso de poder: porque los miembros del cuerpo legislativo no fueran de su opinión, tendría el derecho de quebrar a aquéllos que la Nación había encontrado dignos de su 
Este libro forma parte del acervo de la Biblioteca Jurídica Virtual del Instituto de Investigaciones Jurídicas de la UNAM

selección; interrumpiría sus funciones, cuyo ejercicio no estaría aún terminado; podría despedir a hombres virtuosos que puede ser que no tuvieran otro crimen a sus ojos que su inflexible virtud. No, la razón y la justicia se oponen a semejante disolución... Me parece que he recorrido las diferentes objeciones que se pueden hacer al llamado al pueblo mi diseño ha sido de no olvidar ninguna. He hecho de manera de refutarlas: ignoro si lo he logrado; pero al menos debo creer que los medios de obtener el deseo de la Nación sobre las leyes suspendidas por el monarca no parecerán ya imposibles: podrán todavía parecer difíciles; pero, ¿cuáles son las dificultades que no se deban vencer cuando se trata de restablecer a la Nación en el más precioso de todos sus derechos, cuando se trata de impedir de recaer en la esclavitud? Ahora bien, sostengo, nada es más propio para crear el espíritu público, para extender la luz y la instrucción, para inspirar el amor a la libertad y a la virtud, que hacer participar a todos los ciudadanos en los asuntos públicos, llamando ante ellos, como ante el supremo tribunal, todos los diferendos que puedan suscitarse entre los Poderes que han constituido. ${ }^{190}$

También, en una intervención larga y densa, Sieyès postularía la posición contraria a la concesión del derecho de veto al rey y, en consecuencia, contraria a concebir al Ejecutivo como partícipe en la función legislativa:

...la única definición razonable que puede darse de la ley es la de llamarla expresión de la voluntad de los gobernados. Los gobernantes no pueden apoderarse de ella, en todo o en parte, sin acercarse más o menos al despotismo... Así, pues, el Rey jamás puede ser separado, ni siquiera como idea, de la Nación, cuya majestad plena representa. Cuando la Nación pronuncia su voto, el Rey lo pronuncia con ella. Donde quiera es jefe, donde quiera preside; pero todos estos actos lo suponen presente entre vosotros. En fin, sólo aquí pueden ejercerse sus derechos a la legislación... ¿Un

190 Petion, Jérôme, "Sur le gouvernement représentatif et le droit de veto (5 de septiembre de 1789)", en Furet, François y Halévi, Ran, La Monarchie..., cit., pp. 378-385. 
Este libro forma parte del acervo de la Biblioteca Jurídica Virtual del Instituto de Investigaciones Jurídicas de la UNAM

votante, cualquiera que sea, puede en cualquier asamblea tener más votos que cualquier otro opinante?... Fijaos, señores, en otra consecuencia del sistema que aquí combato. Si el sufragio de un votante pudiese valer en número dos sufragios, no habría razón alguna para que la misma autoridad que le concedió este privilegio político no le otorgase el de pesar lo mismo que 10, que 1000 sufragios. Véis, señores, que de ahí a valer por todos, a substituirlos a todos, no hay más que un paso. Si una voluntad puede valer numéricamente lo que dos voluntades en la formación de la ley, luego puede valer veinticinco millones. Entonces, la ley podría ser la expresión de una sola voluntad; entonces, el Rey podría afirmar que es el único representante de la Nación. Observamos hace un momento que la desigualdad de derechos políticos nos devolvería a la aristocracia: es patente que este sistema odioso no sería menos apto para hundirnos en el más absurdo despotismo... Realmente, señores, si queréis considerar al Rey como depositario de todas las ramas del Poder Ejecutivo, es evidente que no hay nada en su autoridad, por extendida, por inmensa que pueda ser, que pueda entrar, como parte integrante en la formación de la ley. Sería esto olvidar que las voluntades individuales pueden entrar a formar parte, como elementos, de la voluntad general; la ejecución de la ley es posterior a su formación; el Poder Ejecutivo y todo lo que le pertenece no existe sino después de la ley completamente concluida. Antes, todas las voluntades individuales fueron consultadas, o mejor dicho, habían concurrido a la confección de la ley. Por consiguiente no existe nada a lo que se deba llamar para que concurra. Todo lo que podía estar, ya está, nada le falta: no podía haber más que voluntades y todas están ahí...

En el párrafo siguiente, se notará que Sieyès utilizó la misma expresión de Montesquieu, pero en este caso utilizada para fundar la negativa a conceder el veto. Por otra parte, Sieyès tampoco concedía al rey la facultad de iniciar leyes:

$\mathrm{Si}$, entonces, el ejercicio del Poder Ejecutivo proporciona una experiencia, otorga luces que pueden ser útiles al legislador, bueno será escuchar sus consejos, invitarlo a que dé su opinión; pero 
Este libro forma parte del acervo de la Biblioteca Jurídica Virtual del Instituto de Investigaciones Jurídicas de la UNAM

esta opinión es cosa distinta de una voluntad. No debe, repito, entrar en la formación de la ley como parte integrante; en pocas palabras, aunque el Poder Ejecutivo pueda aconsejar la ley, no debe contribuir a hacerla... El derecho de impedir no es, según yo, diferente del derecho de hacer. En primer lugar, es fácil darse cuenta que el ministerio real hará que unos diputados propongan y un partido sostenga todas las leyes que le convengan. Si se aprueban, todo se hará según su voluntad. Si son rechazadas, rechazará a su vez todas las decisiones contrarias. Basta con esta primera observación para darse cuenta de que tal poder es enorme y que aquél que lo ejerza será, poco más o menos, el amo de todo...

En este apartado, Sieyès rechazó la facultad de veto del Ejecutivo y, con buen conocimiento de causa, explicó su existencia en Inglaterra, debido a que los ingleses no hacían distingo entre poder constituyente y poderes constituidos:

$\mathrm{Al}$ término a que he llegado, la cuestión actual cambia de aspecto; se reduce a saber si el derecho de impedir es útil, cuándo lo es y en qué lo es; y dado el caso de que se le creyese útil, si debe ejercerlo el jefe de la Nación, votando en la asamblea legislativa, o en cualquier otra parte de la legislatura. Creo inútil prevenir que el veto, cuya utilidad trato de encontrar, no puede ser el veto que se presentó primero, bajo el nombre de veto absoluto, y que hoy se espera lograr que se acepte más fácilmente con la denominación más suave de veto indefinido o ilimitado. Ignoro qué idea se forman algunos de la voluntad de una Nación, cuando parecen creer que pueda ser anulada por una voluntad particular y arbitraria. No se trata aquí sino del veto suspensivo. El otro, hay que decirlo, no es digno de que se le refute seriamente... En Inglaterra no se ha distinguido el Poder Constituyente del Poder Legislativo; de suerte que el Parlamento británico, ilimitado en sus operaciones, podría atacar la prerrogativa real si no estuviese armada del veto y del derecho de disolver el Parlamento. Este peligro es imposible en Francia. Tendremos como principio fundamental y constitucional el de que la legislatura ordinaria no tendrá el ejercicio del Poder Constituyente, como no tendrá el del Poder Ejecutivo... 
Este libro forma parte del acervo de la Biblioteca Jurídica Virtual del Instituto de Investigaciones Jurídicas de la UNAM

Sieyès volvió a la carga en su rechazo al derecho de veto:

Es necesario ahora examinar la pretendida necesidad del veto real, relativo a la legislación. Busco con cuidado las razones que pueda haber, al menos razones especiosas, en los argumentos de quienes creen en la utilidad del veto y no encuentro nada. Cuando el cuerpo legislativo se limite a hacer leyes tutelares o directivas, cuando el Poder Ejecutivo, cuando el jefe de la Nación no tengan de que quejarse, ni en sus derechos, ni en sus funciones, ni en sus prerrogativas; finalmente, cuando nos limitemos a pedirle al Poder Ejecutivo la ejecución de la voluntad nacional en el orden legislativo, no concibo con qué pretexto se querría que el Poder Ejecutivo se dispensase de ejecutar, y pudiese oponer a la ley un veto suspensivo: sería tanto como decir que cuando los pueblos piden leyes a su asamblea legislativa, es bueno que ésta pueda impedirse el hacerlas. Me parece que cada Poder debe limitarse a sus funciones, pero que debe cumplirlas con celo y sin demora, cuantas veces se lo pidan aquéllos a quienes corresponde tal petición. Fuera de los principios, ya no hay disciplina social en ninguna parte del establecimiento público ¿Se dirá que la experiencia proporciona a los agentes públicos luces que es conveniente consultar antes de hacer las leyes? Sea; que la legislatura busque el consejo de todos aquéllos que están en capacidad de dárselo. Pero, una vez que la ley ha sido hecha, jamás se me convencerá de que corresponda al buen orden el que, quienes están encargados de mandarla ejecutar, puedan ejercer un veto contra el legislador, con el pretexto de que éste pudo equivocarse... ${ }^{191}$

\section{La ingeniería del Poder Legislativo}

Una vez justificados la facultad de veto y el bicamarismo, el mismo diputado de la nobleza Lally-Tollendal procedió a deli-

191 Véanse Sieyés, Emmanuel-Joseph, "El veto. Intervención de Sieyés (7 de septiembre de 1789)", Les grands discours parlamentaires de la Revolution. De Mirabeau á Robespierre. 1789-1795, París, Armand Colin, 2005, pp. 44-46; "Dire de l'abbé Sieyès sur la question du veto royal (7 de septiembre de 1789)", en Furet, François y Halévi, Ran, La Monarchie..., cit., pp. 407-417. 
Este libro forma parte del acervo de la Biblioteca Jurídica Virtual del Instituto de Investigaciones Jurídicas de la UNAM

near la composición de ambas cámaras, su forma de elección, los requisitos de edad y fortuna, las facultades y competencias de ambas, así como las relaciones entre el Ejecutivo y el Legislativo. Debe notarse cómo, sin empacho, dotó al Poder Legislativo de facultades jurisdiccionales y concedió al rey la facultad de disolución del Legislativo:

Estamos convencidos que la Asamblea Nacional debe estar compuesta de dos Cámaras, una llamada Cámara de Representantes y la otra Senado... ¿Cómo estará compuesta la Cámara de Representantes? La respuesta no es difícil; estará compuesta de diputados electos libremente y en común, según las circunscripciones, en las proporciones y con las condiciones que estén reguladas por la Asamblea Nacional... Ha parecido deseable que los diputados alcanzasen la mayoría de edad... Es una cuestión saber si la propiedad debe o no ser exigida en un representante de la Nación... ¿Quién es el más interesado en la conservación de un país, aquél cuya propiedad, cuya existencia dependen del suelo de ese país o aquél que, yéndose, no tendrá ahí nada que lamentar? ¿Cuál tiene que temer más de la venganza pública, aquél al que ella puede desposeer para castigarlo por su prevaricación, o aquél que, al sustraerse por la huída, podrá desafiar el justo resentimiento de sus ciudadanos a los que habrá traicionado?... ¿¿De qué manera estará compuesto el Senado? ¿Estará formado de lo que hoy se llama la nobleza y el clero? No, sin duda; sería perpetuar esta separación de órdenes, este espíritu de corporación, que es el más grande enemigo del espíritu público y que un patriotismo universal concurre hoy a apagar. Por otra parte el número de sus miembros debería ser infinitamente limitado; no sería un derecho de representación el que ellos ejercerían, sería una magistratura política y judicial a la vez, que sería inherente a su persona. El Senado estaría, entonces, compuesto de ciudadanos de todas las clases, a quienes sus talentos, sus servicios, sus virtudes abrirían la entrada... No se podría ser admitido ahí antes de la edad de 35 años... Una propiedad territorial sería necesaria para ser elegible; ésta debería estar determinada... ¿No podría la nominación de los senadores estar compartida entre el Rey y los representantes o bien entre el Rey y los estados provinciales, de manera que el 
Este libro forma parte del acervo de la Biblioteca Jurídica Virtual del Instituto de Investigaciones Jurídicas de la UNAM

Rey escogiera a un sujeto bajo la presentación que le fuera hecha de varios, fuera por los representantes, fuera por las provincias?... Sería al Rey únicamente, como teniendo solo una existencia separada y perpetua a quien pertenecería el derecho de convocar al cuerpo legislativo y él no podría dispensarse en las épocas reguladas por la constitución. Sería él quien pondría a esta gran Asamblea en ejercicio y en descanso conforme a las leyes; podría no solamente prorrogarla, sino disolverla con tal de que al instante él convocara a una nueva. La Cámara de Representantes tendría como la de los Estados americanos y como los Comunes de Inglaterra el derecho exclusivo de deliberar sobre los subsidios, de fijar su extensión, la duración, el modo sobre la demanda que sería hecha por el Rey. El Senado no podría sino consentir o rechazar pura y simplemente el acto que le enviarían los representantes. A estos últimos pertenecería no solamente la deliberación primera, sino la redacción entera de toda ley bursátil y esta fuerza irresistible, perpetua, siempre resurgente en un Estado, no sería jamás de nadie sino de la Nación... El Senado sería un tribunal supremo de justicia, pero en un solo caso. Es ante él que serían perseguidos, es por él que serían juzgados públicamente todos los agentes superiores del poder público acusados de haber hecho uso contrario a la ley. Sólo la Cámara de Representantes podría intentar la acusación... ${ }^{192}$

En una posición consecuente con la tradición francesa de la indivisibilidad y la unidad, Sieyès rechazó el bicamarismo, pero propuso una alternativa artificiosa consistente en el funcionamiento por secciones de la Cámara única, como medio para evitar los excesos del Legislativo:

Este medio, que concilia todos los intereses propende a formar, no dos o tres Cámaras, sino dos o tres secciones de la misma Cámara. Acordaos, señores, de vuestro decreto del 17 de junio: es fundamental, ya que de ese día data vuestra existencia en la Asamblea Nacional; habéis declarado que la Asamblea Nacional es una e indivisible. Lo que constituye la unidad y la indivisibilidad de una

192 Lally-Tollendal, op. cit., pp. 345-359. 
Este libro forma parte del acervo de la Biblioteca Jurídica Virtual del Instituto de Investigaciones Jurídicas de la UNAM

asamblea es la unidad de decisión y no la unidad de discusión. Es evidente que, a veces, resulta bien discutir dos y aún tres veces la misma cuestión. Nada impide que esta triple discusión se realice en tres salas separadas, ante tres divisiones de la Asamblea, sobre las cuales, entonces, ya no tenéis que temer la acción de la misma causa de error, de precipitación, o de seducción oratoria. Bastará con que la decisión o el decreto no pueda ser sino el resultado de la mayoría de los sufragios recogidos en las tres secciones, de la misma manera que se los recogería si todos los diputados se encontrasen reunidos en la misma sala; esto es, para decirlo en el lenguaje de uso, con tal que los sufragios se emitan por cabezas y no por Cámaras... Incluso no habría necesidad de conceder el veto a nadie, pues se encuentra naturalmente en la división indicada, ya que, si una sección de la asamblea considera conveniente retardar su discusión, por eso mismo obtendréis todo el efecto de veto suspensivo... Por lo tanto, a él debemos atenernos. No veo, en efecto, por qué si el ejercicio de un veto suspensivo es bueno y útil, se le sacaría del lugar que la naturaleza de las cosas le ha enseñado en la propia legislatura. El primero que, en mecánica, hizo uso del regulador, se cuidó mucho de colocarlo fuera de la máquina cuyo movimiento demasiado precipitado, deseaba moderar. Por lo demás, hemos demostrado, hemos reconocido anteriormente que el derecho de impedir o de suspender frecuentemente no es sino el derecho de hacer, que sentimos renuencia a separarlos; y que, sobre todo, su uso no se debe confiar, en ningún caso al Poder Ejecutivo. ${ }^{193}$

En suma, la Asamblea constituyente rechazó, al fin de cuentas, no sólo la posibilidad del veto absoluto del monarca sobre los actos del Legislativo, pues el carácter absoluto del veto hacía que la voluntad del monarca se convirtiera tan necesaria como la de la Asamblea para producir la ley, reproduciendo así la lógica británica del King in Parliament, y sólo aceptó la solución de compromiso del veto suspensivo que el monarca era llamado a ejercer desde fuera de la Asamblea, como jefe del Ejecutivo. La Asamblea descartó también el bicamarismo que tenía su orígen

193 Sieyès, Emmanuel-Joseph, "Palabras del abate...", cit., pp. 207-218. 
Este libro forma parte del acervo de la Biblioteca Jurídica Virtual del Instituto de Investigaciones Jurídicas de la UNAM

en la necesidad de equilibrar el elemento aristocrático con el democrático, diferenciando las modalidades de acceso a ambas Cámaras, como sucedía en el caso de los Commons y en el de los Lords, pues no podía ser de otro modo en una Revolución que se alimentaba de la oposición histórica al pasado del antiguo régimen, es decir, de la lucha contra el privilegio y el exclusivismo. ${ }^{194}$

\section{La ingeniería de la relación entre las Cámaras}

entre sí y la de éstas frente al rey

En otro apartado del discurso (ya citado) del diputado de la nobleza Lally-Tollendal, llevó a cabo una defensa sólida de la facultad recíproca de impedirse que tenían las cámaras entre sí y frente al rey y éste frente a ellas, con el derecho ilimitado de veto:

¿Será indispensablemente necesaria a la ley esta sanción que será compartida por el Rey en el Poder Legislativo? ¿Podrá rechazarla? ¿Tendrá una negativa, un veto? ¿Tendrá el Senado uno? ¿Será ilimitado o suspensivo este veto?... Después del examen más profundo, a la mayoría de nosotros le ha parecido que preguntar si el Rey tendría un veto ilimitado, sería preguntar si tendría una sanción. Si debe llegar un término en el que la Asamblea Nacional pueda prescindir de la sanción real, esta sanción no existe; el Rey no es una porción del cuerpo legislativo. Si la sanción no existe, si el Rey no tiene un veto ilimitado, si no es una porción del cuerpo legislativo, entonces no hay medio de salvar la prerrogativa real; no hay un obstáculo insuperable al asedio del Poder Legislativo sobre el Poder Ejecutivo, a la invasión, a la confusión de los Poderes, por consecuencia, al derribamiento de la constitución y a la opresión del pueblo... ¿Cuál sería la existencia del Senado? ¿De qué consideración gozaría? ¿Qué influencia tendría? ¿Cómo podría él romper, desviar el choque entre los representantes y el Rey? En fin, ¿qué balance, qué unión esperar entre las dos Cá-

194 Fioravanti, Maurizio, Los derechos fundamentales..., cit., p. 60. 
Este libro forma parte del acervo de la Biblioteca Jurídica Virtual del Instituto de Investigaciones Jurídicas de la UNAM

maras si no tienen una sobre la otra un veto ilimitado?... En dos palabras, si se suprime el veto ilimitado al Rey, con más razón se le suprimirá al Senado: he aquí entonces a la Cámara de Representantes, Poder único y sin límites. Si dejando al Rey el veto ilimitado, se le suprime al Senado, he aquí entonces al Rey y a la Cámara de Representantes expuestos perpetuamente a enfrentarse... Sería posible probar que, en último análisis, poner en entredicho si el veto del Rey será suspensivo o ilimitado es poner en entredicho si se tendrá o no un Rey; ahora bien, la voluntad de la Nación es que haya un Rey y la libertad de la Nación tiene necesidad de un Rey, tiene necesidad de la prerrogativa del Rey, tiene necesidad de la sanción del Rey; en fin no temamos repetirlo, terminando con lo que el conde de Mirabeau ha dicho con la energía que le caracteriza, que más valdría vivir en Constantinopla que en Francia si se pudiera hacer las leyes sin la sanción real...

Al final de la exposición hizo un resumen de lo que consideraba los principios ciertos:

1. Que el cuerpo legislativo debe estar compuesto de tres partes: del Rey, de un Senado y de los representantes de la Nación. 2. Que debe ser derecho y obligación del Rey convocar al cuerpo legislativo en épocas fijadas por la constitución; que puede prorrogarlo y aún disolverlo, con tal de que inmediatamente convoque a otro. 3. Que toda deliberación por los subsidios debe iniciarse en la Cámara de los Representantes, sobre demanda del Rey; que solamente a ellos pertenece el derecho de levantar el acta que los conceda y que el Senado no debe poder sino aceptar o rechazar este acto pura y simplemente. 4. Que el Senado debe ser el único juez de los agentes superiores del poder público acusados de haber hecho uso contrario a la ley; que la Cámara de los Representantes debe ser la única acusadora y que la acusación, el proceso y el juicio deban ser públicos. 5. Que cada Cámara debe juzgar privativamente lo que concierne a su policía y a sus derechos particulares. 6. Que cualquier otro objeto, que cualquier otro acto de legislación debe ser común a las dos Cámaras; que puede iniciarse indistintamente en una o en otra y que si pasa en una, debe ser enviada a la otra. 7. Que la sanción real es necesaria para la 
Este libro forma parte del acervo de la Biblioteca Jurídica Virtual del Instituto de Investigaciones Jurídicas de la UNAM

formación de la ley; 8. Que la iniciativa, es decir, la propuesta y la redacción de las leyes deben pertenecer exclusivamente a las dos Cámaras y únicamente la sanción al Rey; 9. Que ninguna ley puede ser presentada a la sanción real sin haber sido consentida por las dos Cámaras; 10. Que las dos Cámaras deben tener la negativa o el veto una sobre la otra y que el Rey debe tenerlo sobre las dos. ${ }^{195}$

La posición de Mounier sobre la sanción real es de mucha importancia también, ya que como se recuerda, fue el redactor del reporte del trabajo realizado por la Comisión redactora de la Constitución. Empezó por hacer una decidida defensa de la forma representativa de gobierno:

...es una verdad incontestable que el principio de soberanía resida en la Nación, que toda autoridad emana de ella; pero la Nación no puede gobernarse a sí misma. Jamás ningún pueblo se ha reservado el ejercicio de todos los poderes. Todos los pueblos, para ser libres y felices han sido obligados a conceder su confianza a unos delegados, a constituir una fuerza pública para hacer respetar las leyes y a colocarla en las manos de uno o varios depositarios...

Fundó con razones políticas la necesidad de la existencia de dos Cámaras, distinguiendo el momento de establecimiento de la Constitución, momento en el que fue conveniente el monocamarismo, del momento en que ya establecida la Constitución, el funcionamiento de dos cámaras era garantía de equilibrio:

Hemos examinado la importante cuestión, si las leyes deben ser deliberadas en una sola Cámara o si dos Cámaras son absolutamente necesarias. Hemos estado convencidos de la necesidad de distinguir los medios propios para crear una constitución, de aquéllos que deben mantenerla. La Asamblea presente, encargada de fijar la organización de los Poderes y de elevar el edificio de la libertad, debía estar formada por un solo cuerpo, a fin de tener

195 Lally-Tollendal, op. cit., pp. 345-364. 
Este libro forma parte del acervo de la Biblioteca Jurídica Virtual del Instituto de Investigaciones Jurídicas de la UNAM

más fuerza y celeridad; pero este mismo grado de fuerza, si fuera conservado después de la constitución, acabaría por destruir todo... Unos hombres reunidos para hacer las leyes, unos hombres honrados por la confianza pública, considerados como los guardianes, como los depositarios de la libertad del pueblo, tendrían tan gran autoridad que les sería fácil extender los límites de ésta todos los días; y el veto que pudiera oponer el monarca a sus resoluciones sería siempre un arma impotente... Dos Cámaras, al contrario, deliberando separadamente, aseguran la sabiduría de sus respectivas resoluciones, y conceden al cuerpo legislativo la marcha lenta y majestuosa de la que no se debe separar jamás. Es inútil repetir los motivos que determinaron a la Comisión a proponer dos Cámaras y que han sido expuestas por el señor de Lally.

Razonó con atingencia que para que el equilibrio entre las cámaras se produjera, realmente era necesario que tuvieran una composición diferente:

La Comisión ha creído que una de las Cámaras formada por los diputados libre y directamente elegidos por el pueblo en todas las partes del reino, podría ser llamada Cámara de Representantes, y que la otra podría llevar el nombre de Senado; no se ha explicado la composición de éste. Ha estado, no obstante, convencida que los senadores y los representantes deberían estar en una posición diferente, a fin de no estar animados por las mismas pasiones y que si existía una identidad perfecta en las formas de su elección, serían constantemente dirigidas por las mismas vías; que entonces el Senado no podría ya mantener a la constitución, oponerse a la precipitación de los representantes y proteger, al mismo tiempo, la libertad de los ciudadanos y las prerrogativas de la corona...

Ligando el sistema representativo al mandato representativo, abundó en sus conveniencias:

A propósito de las elecciones de los representantes, la comisión examinó esta cuestión, si los electores podrían en el futuro dictar sus voluntades particulares a sus diputados, o si debían limitarse 
Este libro forma parte del acervo de la Biblioteca Jurídica Virtual del Instituto de Investigaciones Jurídicas de la UNAM

a elegirlos. Ha reflexionado que cuando un pueblo no tiene una constitución determinada, sus representantes no pueden ejercer otras funciones que aquéllas que le han sido prescritas por los habitantes del distrito donde han sido escogidos; no son entonces sino procuradores fundados, sino portadores de poderes: pero una Nación que quisiera persistir en semejante uso no debería emprender formar una constitución; su gobierno sería destruido muy pronto. Sería imposible a hombres que deliberan al mismo tiempo a grandes distancias, no digo de aclararse, ni de formar una resolución común, pero ni siquiera tener acuerdo sobre los objetos de sus demandas. El cuerpo legislativo estaría sin fuerza; cada uno estaría obligado a presentar su cuaderno como la ley suprema a la cual es necesario someterse. Las provincias o los distritos querrían muy pronto hacer prevaler su opinión en la asamblea general; querrían subordinar todo a sus intereses. Muy pronto se vería renacer el choque de sus pretensiones, y enseguida los cuadernos de quejas. Las asambleas se volverían inútiles, y la libertad pública sería aniquilada. Es necesario que un pueblo, que no puede deliberar en un solo cuerpo, acuerde su confianza, delegue el ejercicio de su soberanía, y dé a aquéllos que serán electos en las diversas partes del Estado el derecho de deliberar por él; puesto que nada hay más peligroso, de más propio a favorecer la anarquía y la discordia, de más contrario a todos los principios, que dividir a un pueblo en una multitud de cuerpos separados para hacerlos deliberar sobre los asuntos públicos...

El apartado subsecuente revela la claridad con la que la Comisión Redactora de la Constitución diseñaba el funcionamiento del Poder Legislativo, al señalarle tiempos precisos para sus periodos ordinarios y la posibilidad de tener periodos extraordinarios, sin mostrar empacho alguno a que el Ejecutivo actuara sobre el Legislativo, al convocarlo a sesiones extraordinarias:

La Comisión ha entendido por permanencia, una asamblea siempre lista a formarse, diputados siempre existentes, una sesión anual de pleno derecho, sin necesidad de convocatoria... Si tuvieran la facultad de permanecer constantemente reunidas, podrían 
Este libro forma parte del acervo de la Biblioteca Jurídica Virtual del Instituto de Investigaciones Jurídicas de la UNAM

multiplicar sin medida las leyes y los reglamentos, o entrar en los detalles de administración y vulnerar al Poder Ejecutivo. La Comisión ha creído que debería fijarse un término de cuatro meses, durante el cual los miembros del cuerpo legislativo no podrían ser interrumpidos en sus trabajos; que cuando ellos los hubieran terminado, advertirían al Rey quien tendría el derecho de exigir la continuación de sus sesiones, si juzgaba necesario proponerles tomar cualquier objeto en consideración. El Rey podría además llamar al cuerpo legislativo en el intervalo de sus sesiones ordinarias...

Mostrando un conocimiento notable sobre el funcionamiento de una monarquía parlamentaria, concedió al Ejecutivo el derecho de disolución de la Asamblea:

El derecho de disolver la Cámara de representantes y de ordenar una nueva elección ha sido juzgada indispensable para el mantenimiento de la monarquía; es el único medio que, en tiempos problemáticos, es propio a preservar al trono de los esfuerzos de un partido ambicioso o de descontentos. No puede haber ningún peligro para la libertad pública si el acto de disolución es considerado como nulo, a menos que no contenga una nueva convocatoria...

Con una concepción flexible de la separación de poderes, la Comisión Redactora, por boca de Mounier, estableció la posibilidad de un diálogo entre el Legislativo y el Ejecutivo por conducto de los ministros. Sin embargo, negó la facultad de iniciativa de ley al Ejecutivo:

Las dos Cámaras podrían aclararse mutuamente, en audiencias públicas, estas mismas audiencias podrían tener lugar con los ministros. El Rey tendría la facultad de recomendar por mensajes el tomar un objeto en consideración; pero no tendría el derecho de redactar leyes, pues sería de temer que, instruido de antemano por el conocimiento que le daría la administración de todas las leyes que serían necesarias, pudiera prevenir los deseos de los 
Este libro forma parte del acervo de la Biblioteca Jurídica Virtual del Instituto de Investigaciones Jurídicas de la UNAM

representantes, atribuirse por el uso el derecho exclusivo de proponer las leyes y de aprovechar todas las circunstancias favorables para librar ataques indirectos a la libertad...

A través de Mounier, delineó la Comisión la figura del "Gran Jurado", compuesta por las dos cámaras y con funciones jurisdiccionales, tal y como funcionaba en Inglaterra, con lo que se introdujo el principio de responsabilidad:

El Senado, siguiendo el plan de la Comisión, juzgaría los crímenes cometidos en las funciones públicas por los agentes superiores del Poder Ejecutivo o de la administración del reino. El Poder Ejecutivo sería muy pronto enervado, si los tribunales ordinarios tuvieran el derecho de juzgar a los ministros. Semejantes crímenes, interesando a la Nación entera, no pueden ser perseguidos sino por los representantes. Sería tan funesto librar a los ministros a venganzas particulares como dejar impunes sus prevaricaciones. No sería conveniente a la dignidad de los representantes acusar ante un tribunal sobre el cual tuvieran, por otra parte, una influencia demasiado grande. El juicio de los crímenes de Estado necesita, entonces, dos Cámaras y, sobre todo, necesita dos Cámaras que no tengan la misma posición y que no abracen ciegamente todos sus proyectos, todas sus pretensiones respectivas. Un pueblo no es libre jamás, si los ministros, los jueces y los otros agentes de la autoridad no son responsables...

En el párrafo siguiente, la Comisión Redactora de la Constitución, por la vía de Mounier, proporcionó evidencia palpable de la influencia que El espiritu de las leyes ejercía sobre el pensamiento de la época, pues, con paráfrasis del capítulo dedicado a la Constitución de Inglaterra, nos brindó el concepto de la separación de poderes y los mecanismos para forzar a los gobernantes para no excederse en el ejercicio del poder, como veremos más adelante:

Cualquiera que sea la forma de un gobierno, el cuidado más importante debe ser impedir a los depositarios de todos los géneros de autoridad seguir todas sus voluntades y establecer una fuerza 
Este libro forma parte del acervo de la Biblioteca Jurídica Virtual del Instituto de Investigaciones Jurídicas de la UNAM

arbitraria. Para conseguirlo, hay que combinar la organización de diferentes Poderes, de manera que no estén reunidos jamás en las mismas manos. En todas partes donde se encuentra la reunión o la confusión de Poderes hay despotismo. La libertad no existe, si la fuerza pública, si los juicios son dirigidos por una voluntad arbitraria, tal como lo inspiran las circunstancias o las diversas pasiones. Es necesario que leyes anteriores, preparadas durante la calma y después de largas reflexiones, les sirvan siempre de guía. Si los Poderes están reunidos, aquéllos que los ejercen no están retenidos por ningún freno; hacen leyes al gusto de sus intereses; dan este nombre respetable a todos sus caprichos; les atribuyen en la ejecución un efecto retroactivo, y el sentido que conviene a sus pasiones; se consideran como los árbitros supremos e infalibles del destino de sus semejantes; pero si los Poderes son distintos, si límites insuperables se oponen a su reunión, si el Poder Legislativo está constituido de manera que aquéllos que lo ejercen deban querer la felicidad general, que sean suficientemente esclarecidos para no pronunciar leyes absurdas, y que no puedan decidir con precipitación, el pueblo no sabría ser esclavo, y el saludable yugo de las leyes es el único que puede existir. He aquí entonces a donde deben tender todos los esfuerzos de aquéllos que se ocupan de la organización de un gobierno: es a la división de los Poderes; pero para que ellos se mantengan divididos, es necesario que estén garantizados contra sus ataques o sus usurpaciones recíprocas. Para garantizar el poder confiado a los representantes, para impedir al monarca hacer leyes de acuerdo a su voluntad, y de derribar la constitución, los medios se presentan por multitudes: la permanencia del cuerpo legislativo, la resistencia de los representantes, su derecho exclusivo de proponer la ley, la libre concesión del impuesto, la responsabilidad de los ministros, las administraciones provinciales, las municipalidades, las milicias burguesas, la libertad de prensa...

En esta pertinente lectura de Montesquieu y del diseño constitucional de las instituciones políticas inglesas, Mounier hizo al Ejecutivo partícipe de la función legislativa y mostró claramente que para que operara la distinción y separación de poderes, era menester que su separación no fuese tajante. Por lo demás, 
Este libro forma parte del acervo de la Biblioteca Jurídica Virtual del Instituto de Investigaciones Jurídicas de la UNAM

contiene una afirmación explícita de la superioridad del Poder Legislativo:

Es necesario, entonces, examinar con la atención más severa por qué medios se podría garantizar al Poder Ejecutivo de todos los asedios del Poder Legislativo. El medio que se presenta más natural es el de dar al Rey la porción integrante del cuerpo legislativo, y de exigir que las decisiones de los representantes, para convertirse en leyes, estén revestidas de la sanción real. Así, para que los diferentes Poderes se mantengan por siempre divididos, es necesario no separarlos enteramente. El poder de hacer la ley debe ser y es en efecto superior al poder que la ejecuta. Si el Rey no fuera una porción del cuerpo legislativo, si se pudiera hacer leyes sin su consentimiento, no gozaría ya de su potestad soberanamente y estaría sometido al cuerpo legislativo que, por las leyes, adquiriría la facultad de dictarle órdenes absolutas, y de anular sucesivamente todas sus prerrogativas... Es necesario, entonces, para el mantenimiento de la autoridad del Rey, que ninguna ley exista sin la sanción real; y no se puede decir que sea una reunión de los Poderes en las mismas manos; pues el Rey no se encontraría revestido de los Poderes Legislativo y Ejecutivo. Estos Poderes serían siempre distintos y divididos, puesto que no tendría la facultad de hacer leyes... La sanción real no puede ser otra cosa que el consentimiento dado al Rey a todos los actos de legislación. Casi todos nuestros comitentes han pensado que este consentimiento era necesario. Si no se dejara al Rey más que la facultad de suspender los actos legislativos, es evidente que no se podría ya decir que las leyes están hechas con la sanción real y que sería necesario solamente fijar el término durante el cual el Rey tendría la facultad de suspender. El cuerpo legislativo, persistiendo en sus resoluciones, haría, entonces las leyes sin el consentimiento del príncipe. Así, la sanción real no sería ya necesaria, y la esperanza de nuestros comitentes que han querido que el Rey compartiera la potestad legislativa sería frustrada...

En un apartado siguiente se consignó un alegato en favor del veto absoluto, rechazando el veto suspensivo, ya que se dice, debilitaría al Ejecutivo: 
Este libro forma parte del acervo de la Biblioteca Jurídica Virtual del Instituto de Investigaciones Jurídicas de la UNAM

Para que el poder Ejecutivo conserve la fuerza necesaria al mantenimiento del orden público, es necesario que el monarca, en calidad de jefe de la Nación esté rodeado de una gran majestad. Pero cesará de inspirar el respeto que se debe al trono, si no tuviera más que la facultad de suspender las leyes: los representantes no serían detenidos en sus proyectos; y como una simple suspensión promete un éxito cierto si se persiste, formando una resolución, se prepararía, al mismo, tiempo los medios necesarios para triunfar sobre todos los obstáculos. El pueblo consideraría al príncipe como ajeno a todas las leyes: la facultad de suspender no sería a sus ojos una potestad, puesto que después de un término fijo ya no existiría; y en un Estado libre, la ley siendo superior a toda autoridad, los únicos delegados encargados de establecerla obtendrían una gran consideración pública... La Comisión no ha adoptado la opinión de obligar al Rey a disolver la asamblea de representantes cada vez que él quisiera rechazar su sanción. La sanción real y el derecho de disolver son sin duda esenciales para mantener la independencia de la corona contra las intrigas y las facciones; pero el derecho de disolver, que no hay que establecer, sino en tanto que sea inmediatamente seguido de la nueva convocatoria, es un derecho cuyo uso es extremadamente peligroso; no puede ser excusado si no por los más poderosos motivos...

Como en otros participantes, se sentía en la necesidad de distinguir lo coyuntural - consistente en si debía o no el rey conceder su anuencia a la constitución - de lo estructural - consistente en si debía o no consagrarse el derecho de veto-:

El Rey, antes de ratificar la constitución, puede sin duda examinar lo que concierne a su autoridad existente antes de nuestra delegación; pero si solicitara cambios contrarios a la libertad pública, vosotros tendríais el llamado a vuestros comitentes: pues, desde el momento en que la Nación ha resuelto ser libre, tiene ciertamente todos los derechos necesarios para serlo. Repito, entonces, que se trata aquí de la sanción real por los simples actos de legislación, sanción que el Rey puede rechazar sin explicar los motivos... 
Este libro forma parte del acervo de la Biblioteca Jurídica Virtual del Instituto de Investigaciones Jurídicas de la UNAM

En clara alusión a las consecuencias totalitarias de la concepción rousseauniana de la voluntad general, hizo la defensa del veto absoluto, vinculándolo al sistema representativo:

Para terminar, señores, permitidme regresar de nuevo sobre estas expresiones tan a menudo repetidas, la voluntad general. Permitidme observar que en ningún gobierno conocido se ha tomado por única vía la voluntad de la multitud... Reconocemos la necesidad de confiar el Poder Legislativo a unos representantes, e invocamos ciegamente las máximas de un filósofo que creía que los ingleses no eran libres sino cuando nombraban a sus representantes, que consideraba la representación como un género de servidumbre... ${ }^{196}$

...Sí señores, es para la Comisión un deber sagrado deciros que prevé las consecuencias más funestas si se establece un régimen democrático, haciendo decidir por los electores, en cada distrito del reino, entre el Rey y los representantes, o si se deja a los nuevos representantes la facultad de destruir todo obstáculo a la división de Poderes. La necesidad constante de la sanción real le parece un principio tan respetable como el de la indivisibilidad de la corona... El veto suspensivo degradaría al trono; el Rey sería muy pronto reducido a no ser más que un general de la armada. En ningún Estado monárquico el Rey ha cesado de tener una porción integrante del cuerpo legislativo sin que la aristocracia se vuelva más poderosa. Consultad los anales de Suecia y de Polonia. El derecho de conceder o rechazar la sanción real no tiene peligro para la libertad del pueblo; es, al contrario, la más firme defensa... Aquéllos que quieren conceder al Rey la facultad de suspender las deliberaciones hasta la tercera legislatura creen garantizar suficientemente las prerrogativas reales, pero no reflexionan que destruyen la dignidad del trono, indicando el término en que está forzado a obedecer a los representantes; que una ley, presentada hacia el fin de una legislatura y propuesta de nuevo

196 Mounier hace, sin duda, alusión al pasaje famoso de Rousseau: "el pueblo inglés piensa que es libre, está fuertemente equivocado; no lo es sino durante la elección de los miembros del Parlamento: tan pronto son electos, vuelve a ser esclavo, es nada", Rousseau, Jean-Jacques, op. cit., p. 37. 
Este libro forma parte del acervo de la Biblioteca Jurídica Virtual del Instituto de Investigaciones Jurídicas de la UNAM

por la segunda, sería siempre necesariamente sancionada, para evitar el sinsabor de obedecer a la tercera y que no habría ningún medio cierto para defender la independencia de la corona... ${ }^{197}$

Como ha sido dicho, el 10 de septiembre de 1789 la Asamblea se pronunció contra el bicamarismo y al día siguiente se concedió al rey el veto suspensivo, a cambio de que éste aceptara los decretos del 4 y el 11 de agosto. El artículo 2o., sección III, del capítulo III fue concebido en los siguientes términos, "en caso en que el Rey rechace su consentimiento, este rechazo sólo es suspensivo. Cuando las dos legislaturas que sigan a aquélla que presentó el decreto hayan presentado el mismo decreto en los mismos términos, el Rey estará obligado a dar la sanción."

Sin embargo, quedaba aún por obtener materialmente la sanción real para estos decretos, para que pudieran ser promulgados. La Asamblea insistió, fincada en la concesión que había hecho sobre el veto. El rey respondió con una crítica jurídica minuciosa a los decretos; ante la insistencia de la Asamblea, aceptó publicarlos, pero pretendió someterlos a leyes que los interpretaran y se rehusó a promulgarlos para hacerlos ejecutorios.

$\mathrm{Al}$ mismo tiempo, el rey hizo venir a un regimiento a Versalles, no contento con la crisis de junio y de julio, hilaba una tercera: la llegada de este regimiento despertó las suspicacias de la guardia nacional, ¿por qué hacerles venir, si no es por desconfianza a la guardia burguesa recién creada? Así, en el partido patriota, en la guardia nacional, entre los diputados de la Asamblea y las muchedumbres parisinas se compartía el sentimiento de la necesidad de otra jornada que constriñera a Luis XVI y a su corte a aceptar los decretos. La crisis política se amplificaba con la económica, pues otro año no tan bueno para la agricultura mantenía alto el precio de los alimentos y el desempleo crecía en París.

Llegada a Versalles una muchedumbre - conformada por la mayoría de mujeres de los barrios populares de Saint Antoine

197 Mounier, "Discours de Mounier...," cit., pp. 385-405. 
Este libro forma parte del acervo de la Biblioteca Jurídica Virtual del Instituto de Investigaciones Jurídicas de la UNAM

y de Les Halles - fue recibida una comisión que fue conducida hasta el rey por Mounier, presidente en ejercicio de la Asamblea. Pese a las promesas del rey de avituallar París, la muchedumbre no se retiró y pronto se sumó una segunda columna de marchistas y un regimiento de la guardia nacional. Estos hechos vencieron la resistencia del rey, quien notificó por escrito a Mounier su aceptación de los decretos. Reunido su consejo, la aprobó también. Sin embargo, ya era demasiado tarde, los demandantes no se conformaban y exigían el traslado del rey y de su familia a París.

Con el rey ya despachando en las Tullerías y la Asamblea Constituyente sesionando en una sala cercana, se abrió la etapa de corta duración que se caracterizó por el intento fallido de hacer funcionar un acuerdo político, materializado por una monarquía constitucional. El modelo a seguir era el compromiso feliz a que habían llegado los ingleses, después de "la gloriosa Revolución" y que, a partir de 1688, instauraría un régimen de equilibrio y entendimiento no sólo entre los poderes del Estado, sino entre las clases sociales. Pero las condiciones no eran semejantes en Francia, la intransigencia de la derecha aristocrática se enfrentó al impaciente radicalismo de la izquierda y el compromiso falló, junto con La Fayette, su impulsor.

Esta etapa transitoria estuvo marcada por dos grandes problemas que polarizaron las posiciones políticas: el financiero y el religioso, que en realidad terminaron por mezclarse.

Por una parte, la deuda heredada del antiguo régimen - que hoy se ha calculado en cinco mil millones - no podía ser hecha a un lado por la Revolución y, por la otra, la percepción de ingresos se había colapsado, pues las antiguas contribuciones se cobraban con mucha dificultad. La solución se iría a buscar ahí donde no se lastimaran los intereses de las bases sociales de apoyo del nuevo régimen, es decir, de la burguesía y su clientela. Fue así que a un obispo - Talleyrand - tocó proponer la nacionalización de los bienes del clero. La propuesta fue aprobada el 2 de noviembre de 1789, por una mayoría de 568 votos contra 346. Resulta obvio 
Este libro forma parte del acervo de la Biblioteca Jurídica Virtual del Instituto de Investigaciones Jurídicas de la UNAM

decir que el objetivo no era sólo fiscal sino político: se trataba de crear un grupo compacto de nuevos propietarios cercanos a la Revolución que al verse beneficiados por la venta con facilidades de los bienes incautados, se convertirían en aliados del Tercer Estado. ${ }^{198}$

Hasta ahí la relación del nuevo Estado con el clero no resultaba demasiado dañada. Pese a la supresión del diezmo y a la nacionalización de los bienes, que a la mayoría de clérigos y fieles no le había gustado, seguía anteponiéndose su simpatía por la Revolución. Mas no todo iría a ser miel sobre hojuelas.

La Declaración de los Derechos del hombre, de agosto del 89, se había reservado bien el no decretar abiertamente la libertad de cultos; sin embargo, al afirmar que nadie podía ser molestado por sus opiniones religiosas, abría la puerta a la tolerancia. La Iglesia comenzó a dar signos de inquietud ante la posibilidad de la laicización del Estado, que la vivía como una amenaza. Mucho más grave fue la intervención de la Asamblea Constituyente, en materia de organización eclesiástica, al prohibir y disolver órdenes monásticas, al pretender que curas y obispos fueran designados por elección popular y al considerarlos como asalariados del Estado y, en consecuencia, sometidos al juramento de fidelidad a la Constitución, por lo que su investidura ya no dependía del Vaticano.

Aunque el rey firmó el decreto que contenía estas decisiones, se exigía la aprobación del pontífice romano para legitimar la reforma. La Asamblea Constituyente expidió un decreto, el 27 de noviembre de 1790, dando un plazo de dos meses a los curas para prestar el juramento a la Constitución y a la Constitución civil del clero, que la incluía. Esto marcó la ruptura: sólo un tercio de los curas de la Asamblea accedió a prestar el juramento en enero de 1791 y el papa Pío Sexto anatemizaría a la constitución civil del clero el 10 de marzo de 1791.

Dentro de las vacilaciones y torpezas del rey, una más iría a sellar su suerte: lo pésimo del plan y lo peor operado de su huída,

198 Furet, François y Richet, Denis, La Revolution..., cit., p. 194. 
Este libro forma parte del acervo de la Biblioteca Jurídica Virtual del Instituto de Investigaciones Jurídicas de la UNAM

el 20 de junio de 1791. A las once de la noche del día siguiente lo toman como prisionero en Varennes.

\section{LA LENTA Y TORTUOSA ELABORACIÓN DE LA CONSTITUCiÓN}

En lo que concierne a la elaboración de la Constitución propiamente dicha, el 6 de julio de 1789 la Asamblea nombró treinta comisiones para establecer un plan de trabajo. El 9 de julio, en nombre de los comisionados, se presentó un primer reporte en el que se propuso un orden de trabajo, sobre la Constitución del reino, conteniendo el enunciado de diez principios a los que debía circunscribirse la futura Comisión Redactora. He aquí dicho orden de trabajo:

Art. 1. Todo gobierno debe tener por fin único el mantenimiento del derecho de los hombres: de donde se sigue que, para recordar constantemente al gobierno el fin propuesto, la constitución debe comenzar por la Declaración de los derechos naturales e imprescriptibles del hombre. Art. 2. Siendo el gobierno monárquico propio para mantener sus derechos, ha sido escogido por la Nación francesa; sobre todo, es conveniente para una gran sociedad; es necesario para la felicidad de Francia: la declaración de los principios de ese gobierno, en consecuencia, debe estar a continuación de la Declaración de los Derechos del Hombre. Art. 3. Resulta de los principios de la monarquía que la Nación, para asegurar sus derechos, ha concedido al monarca derechos particulares. La constitución debe, en consecuencia, declarar de una manera precisa los derechos de uno y de otro. Art. 4. Es necesario comenzar por declarar los derechos de la Nación francesa. Es necesario enseguida declarar los derechos del Rey. Art. 5. Los derechos del Rey y de la Nación no existiendo más que para la felicidad de los individuos que la componen, conducen al examen de los derechos de los ciudadanos. Art. 6. No pudiendo reunirse la Nación francesa de manera individual, para ejercer todos sus derechos, debe estar representada: es necesario enunciar el modo 
Este libro forma parte del acervo de la Biblioteca Jurídica Virtual del Instituto de Investigaciones Jurídicas de la UNAM

de su representación y los derechos de sus representantes. Art. 7. Del concurso de los poderes de la Nación y del Rey deben resultar el establecimiento y la ejecución de las leyes: así, es necesario primero determinar cómo serán establecidas éstas. En seguida se examinará cómo serán ejecutadas. Art. 8. Las leyes tienen por objeto la administración general del reino, las acciones de los ciudadanos y las propiedades. La ejecución de las leyes que concierne a la administración general exige asambleas provinciales y asambleas municipales. Es necesario, entonces, examinar cuál debe ser la organización de las asambleas provinciales y cuál la de las asambleas municipales. Art. 9. La ejecución de las leyes que conciernen a las propiedades y a las acciones de los ciudadanos necesita el Poder Judicial; es menester determinar cómo será confiado; es necesario determinar enseguida sus obligaciones y sus límites. Art. 10. Para la ejecución de las leyes y la defensa del reino es necesaria una fuerza pública. Se trata, en consecuencia, de determinar los principios que deben dirigirla. ${ }^{199}$

Ya para el 27 del mismo mes Mounier y Champion de Cicé, a nombre de esta comisión, rindieron un informe en el que enunciaron treinta y cinco propuestas reagrupadas en un capítulo titulado "Principios del gobierno francés" y precedidas de una declaración de derechos de veintitrés artículos. ${ }^{200}$

Como se recordará, el mes de agosto fue consagrado a la redacción de los decretos, producto de la noche del 4 de agosto, y a la discusión y elaboración de la Declaración de Derechos, aprobada el 26 de dicho mes. Desde esa fecha, hasta el fin del mes de septiembre, fueron adoptados por la Asamblea Nacional los principales elementos de la futura Constitución. Los artículos relativos al veto, a la regularidad de las sesiones de la Asamblea y al monocamarismo fueron votados antes de que se votara por el gobierno monárquico. Las discusiones más largas y más apasionadas fueron las dedicadas al veto, ya que duraron once días

199 Mounier, "Rapport de Mounier...," cit., pp. 318 y 319.

200 Verpeaux, M., op. cit., p. 7. 
Este libro forma parte del acervo de la Biblioteca Jurídica Virtual del Instituto de Investigaciones Jurídicas de la UNAM

sin interrupción, pero, se mezclaron con muchos problemas de diseño institucional por lo que fueron riquísimas.

Debido al rechazo del veto absoluto, los monarquistas de la Comisión Redactora de la Constitución renunciaron y fueron substituidos por Démeunier, Rabaut Saint-Etienne, Target, Thouret y Tronchet. ${ }^{201}$ Todavía restaban numerosas cuestiones por resolver de manera que (el 29 de septiembre) Target, a nombre de la Comisión, levantó su inventario y la adopción de esos artículos se hizo rápidamente, entre el 30 y el 1 de octubre. Así, casi todo fue decidido en los primeros meses. ${ }^{202}$

La Asamblea se dedicó a reordenar los artículos de la Declaración de Derechos y de la Constitución ya aprobados, para ser propuestos a la aceptación del rey. Como se recordará, éste manifestó sus reticencias para conceder su aceptación, pero no era cuestión de interponer un veto sobre el decreto, puesto que no se trataba de leyes ordinarias, sino de ordenamientos constitucionales. Las jornadas de octubre, que forzaron a Luis XVI a abandonar Versalles, llevarían la aceptación de éste hasta el 3 de noviembre y le constreñirían también para aprobar los decretos de la noche del 4 de agosto. Desde luego, no se puede pensar que ya toda la obra estaba terminada para entonces, porque el texto del decreto, compuesto de diecinueve artículos, era demasiado corto para ser considerado una Constitución. No obstante, estas disposiciones operaron como Constitución hasta la fecha de su adopción definitiva, lo que prueba que los principios fundamentales ya estaban planteados. ${ }^{203}$

Lo que siguió fue largo y caótico. Al final del año 89 se dedicó a la elaboración legislativa sobre elecciones, administraciones locales y divisiones administrativas, y sobre la atribución a la Nación de los bienes eclesiásticos. Durante 1790 se adoptó la legislación sobre la organización judicial, de la cual una parte debía integrarse a la Constitución y la discusión se prosiguió en 1791

\footnotetext{
201 Ibidem, p. 7.

202 Ibidem, p. 8.

203 Ibidem, p. 9.
} 
Este libro forma parte del acervo de la Biblioteca Jurídica Virtual del Instituto de Investigaciones Jurídicas de la UNAM

con la legislación relativa a los ministros, al derecho de petición y a la organización de la Asamblea.

La fuga del rey, en junio de 1791, provocó numerosos debates sobre el lugar que le debía ser asignado en el conjunto de las instituciones y hubo que esperar hasta el 8 de agosto de 1791 para que el texto completo de la Constitución fuera comunicado a la Asamblea por Thouret, a nombre de la Comisión Redactora. Finalmente, el 3 de septiembre de 1791, a propuesta de Lanjuinais la Constitución fue declarada, aprobada y cabalmente terminada. 204

Sólo puede explicarse este tortuoso y largo término en los trabajos de la Asamblea Constituyente por los obstáculos numerosos que al principio interpusieron los órdenes privilegiados, después, por la permanente actitud negativa y hostil del rey y por lo complicado de los temas por resolver: la Constitución civil del clero, la edificación de las nuevas instituciones administrativas, entre otros. Debe agregarse que aunque en este prolongado camino, en ocasiones, se acentuaron los aspectos más conservadores de los decretos ya adoptados, la marcha atrás fue menos importante de lo que hubieran deseado los partidarios del retorno al pasado y sólo prosperaron algunas enmiendas. ${ }^{205}$

Más forzado por las circunstancias que accediendo con agrado, el 14 de septiembre de 1791, el rey aceptó la Constitución y se comprometió a defenderla y a hacerla cumplir. Para formalizar ese compromiso acudió a la Asamblea, ante la cual prestó un juramento al que no estaba obligado. Aunque pudiera considerarse esta fecha como la de la adopción definitiva de la Constitución, no ha sido así, sino que es la del 3 de septiembre, con el propósito de simbolizar con ello que el lugar del rey estaba "dentro" de la constitución y no por "encima" de ella. Quedaba claro, entonces, que no se trataba de una "carta concedida" o de un pacto entre la nación y el rey, considerados como dos fuerzas situadas frente a frente en el mismo plano, sino de una verdadera

204 Ibidem, p. 10.

205 Idem. 
Este libro forma parte del acervo de la Biblioteca Jurídica Virtual del Instituto de Investigaciones Jurídicas de la UNAM

Constitución y, en ese sentido, preexistía a los poderes que creaba y cuyas relaciones organizaba. ${ }^{206}$

La Constitución está dividida en siete títulos, algunos de éstos están subdivididos en capítulos y secciones, y contiene en total doscientos diez artículos, cuya enumeración se inicia en cada título, capítulo o sección. Tanto el preámbulo como el título I recuerdan y, a veces, desarrollan los principios expuestos en la Declaración de Derechos; el título II se consagra a la división del reino; el título III regula el funcionamiento de los poderes públicos; el título IV trata de la fuerza pública; en el título $\mathrm{V}$ se plantean los principios de la organización financiera; el título VI se ocupa de las relaciones de Francia con las otras naciones y, finalmente, el título VII contiene las reglas para reformar la Constitución.

\section{LA EVOLUCIÓN DE LA CONGEPCIÓN SOBRE LA MONARQUÍA}

Como se recordará, todavía en la noche del 4 de agosto, la Asamblea Nacional no tuvo empacho en declarar a Luis XVI "restaurador de la libertad francesa", a propuesta de uno de los grandes abogados de la monarquía; sin embargo, la ambigüedad de reconocer, por un lado, la soberanía nacional y, por otro, mantener la soberanía monárquica iría a durar muy poco tiempo.

Los monárquicos moderados - aún no hostiles a una revolución, que ellos mismos habían alentado, sostenido y guiadoestaban ya para entonces ansiosos por frenar las consecuencias de su iniciativa y, sobre todo, por apagar la efervescencia, de que era presa el país, por lo que acudieron a un modelo que para su desgracia, no tenía asidero en la tradición histórica francesa: no existía en sus precedentes nada que se pareciera al King in Parliament que se instauró en Inglaterra, a partir de 1688.

206 Ibidem, p. 12. 
Este libro forma parte del acervo de la Biblioteca Jurídica Virtual del Instituto de Investigaciones Jurídicas de la UNAM

En efecto, la herencia del absolutismo borbónico fue la de una soberanía indivisible, depositada en la persona del rey y contraria, por tanto, a la co-soberanía o soberanía compartida entre un rey, una cámara de los Lores y una cámara de los Comunes, que "cohabitaran" en un equilibrio sutil. De esta forma, fue más fácil instalar a la nación en el trono que antes ocupara el rey, al apropiarse de esa soberanía - una, indivisible, inalienable e imprescriptible, al fin y al cabo producto del absolutismo - que reinventar una fórmula, que pudiera haberse originado, de haberse mantenido la tradición que constreñía a la corona a consultar con los Estados Generales, pero que, por haberse interrumpido, carecía de fundamento histórico. ${ }^{207}$

En una evolución rápida, en el seno de la Asamblea Constituyente, el rey fue dejando de ser el detentador de la soberanía, para convertirse en el primer funcionario del reino. Se había producido un derrocamiento simbólico del trono el 17 de junio de 1789, cuando se constituyó la Asamblea Nacional, pero este acto de transformación revolucionaria aún se encontraba encubierto tras una concepción que poco a poco iba emergiendo y que veía en el rey a un servidor del pueblo y que progresivamente fue confinando a Luis XVI en las funciones subordinadas de un jefe del Poder Ejecutivo. ${ }^{208}$

Con todo, no solamente las tradiciones constreñían a la Asamblea, sino que no se concebía de manera distinta al Ejecutivo: éste tenía que ser monárquico. Retomando un debate iniciado un mes antes, el 22 de septiembre de 1789, la Asamblea votó que "el gobierno francés era monárquico" en el artículo 4o., título III, no obstante, al momento de definir las facultades del rey, las restringió lo más posible, cuidando de no desarmarlo por completo frente a las presiones populares. Si bien se adoptaba al gobierno monárquico, el artículo 3o., capítulo II afirmaba que "no hay en Francia autoridad superior a la ley. El rey no reina

207 Furet, François y Halévi, Ran, La Monarchie..., cit., pp. 179-181.

208 Ibidem, pp. 182 y 183. 
Este libro forma parte del acervo de la Biblioteca Jurídica Virtual del Instituto de Investigaciones Jurídicas de la UNAM

más que por ella y no es más que en nombre de la ley que puede exigir obediencia".

Al día siguiente (23 de septiembre) la Asamblea insistió en subordinar todavía más la autoridad real a la nación: los artículos 2o. y 3o. del título III prescribían que todos los poderes emanaban esencialmente de ella y no podían emanar sino de ella y que el Poder Legislativo residía en la Asamblea Nacional. Mas, no se había dejado desprovisto al poder monárquico, pues ya la Asamblea se había pronunciado, el 11 de septiembre anterior, por el veto suspensivo que aunque permitía al rey obstaculizar cualquier tentativa legislativa contraria a su parecer dejaba a la Asamblea como árbitro en última instancia.

Por otra parte, el día anterior (10 de septiembre) la Asamblea rechazó - en una decisión congruente con su obsesión por la unidad e indivisibilidad - la posibilidad del bicamarismo, al negarse a aprobar el establecimiento de una cámara alta, con lo que se imposibilitaba la existencia de un puente entre la nobleza feudal y la monarquía. A fin de afirmar la preeminencia de la Asamblea, el derecho de disolverla también fue negado al rey, en el artículo 5o., capítulo 1, título III: "el cuerpo legislativo no podrá ser disuelto por el Rey".

El proceso de desmantelamiento de la institución monárquica, llevado a cabo por la Asamblea, prosiguió después de las jornadas de octubre. El día 8 un decreto cambió el título del "Rey de Francia y de Navarra" por el de "Rey de los franceses", tal como lo señala el artículo 2o., capítulo II. Sin atreverse a negar totalmente el carácter divino de la monarquía, el día 10, la Constituyente estableció que el rey se llamaría, en adelante "Luis, por la gracia de Dios y la ley constitucional del Estado, rey de los franceses". Este giro en la concepción era dramático: la realeza dejaba de ser un sacerdocio, el rey ya no era un taumaturgo, casi dotado de poderes mágicos. En adelante no sería un amo, sino un jefe, el primer magistrado de la nación.

En algunos artículos votados el 9 de noviembre de 1789 se deseó hacer manifiesta la subordinación del rey a la Asamblea. 
Este libro forma parte del acervo de la Biblioteca Jurídica Virtual del Instituto de Investigaciones Jurídicas de la UNAM

Según el artículo 1o. de la sección III, los decretos del cuerpo legislativo serían presentados al Rey, que podría rechazarles su consentimiento. Su anuencia se expresaba en cada decreto, según el artículo 3o. de la misma sección, por la fórmula: “...el Rey consiente y hará ejecutar...". En el caso de hacer uso del veto suspensivo por la fórmula de: "el Rey examinará...". La fórmula de promulgación ordenada por el artículo 3o., sección 1 ra era: "...la Asamblea Nacional ha decretado y nosotros queremos y ordenamos lo que sigue...". 209

La sucesión al trono sería fijada en adelante por la Constitución y no por una "ley fundamental del Estado", misteriosa y que se prestaba a discusión. El artículo 1o., del título III, capítulo II, sección 1ra. establecía la ley sálica, "la realeza es indivisible y delegada hereditariamente de varón en varón por orden de primogenitura, con exclusión perpetua de las mujeres y de su descendencia".

Este rey de los franceses era hereditario, pero se le subordinaba a la constitución por un juramento previsto en los artículos 4o. y 5o. de la sección 1ra, capítulo II: A su advenimiento al trono o desde que hubiera alcanzado la mayoría de edad tenía que prestar el juramento ante el cuerpo legislativo "de ser fiel a la Nación y a la ley, de emplear todo el poder que le es delegado, a mantener la Constitución decretada por la Asamblea Nacional Constituyente en los años 1789, 1790 y 1791 y a hacer ejecutar las leyes". Si después de un mes de haber sido invitado por el cuerpo legislativo el rey no hubiera prestado ese juramento, o si después de haberlo prestado, se retractara, sería obligado a abdicar del trono.

Otra discusión de importancia fue la relativa a conceder o rechazar el carácter de representante al rey. Por su parte, Roederer se negaba a que al rey se le concediera la calidad de representante, fundado en que dicha calidad debía estar ligada a la elección y el rey no era electo y en que únicamente podían representar a

209 Las fechas de las votaciones se tomaron de Soboul, Albert, op. cit., pp. 213-215. 
Este libro forma parte del acervo de la Biblioteca Jurídica Virtual del Instituto de Investigaciones Jurídicas de la UNAM

la nación los que expresaran la voluntad nacional; es decir, aquéllos que detentaran el Poder Legislativo. Si el veto suspensivo era una participación al Poder Legislativo, entonces, el rey tendría la calidad de representante y, en caso contrario, habría que rehusárselo. Roederer se negaba a concedérselo. Robespierre, que para entonces había cambiado de parecer, concordaba con la opinión anterior. ${ }^{210}$

Thouret tenía una propuesta diferente: en tanto que detentador del Poder Ejecutivo, el rey no debía ser calificado de representante, sino de funcionario. Pero, en la medida en que ejercía el Poder Legislativo era representante. El rey poseía la sanción sobre los decretos del cuerpo legislativo y en el ejercicio de este derecho era representante. ${ }^{211}$

Igualmente, para Barnave, lo que distinguía al representante de aquél que no era sino simple funcionario público, era que en ciertos casos estaba encargado de querer por la nación, en tanto que el simple funcionario público no estaba jamás encargado de actuar por ella. El rey era representante de la nación en cuanto que consentía y quería por ella que los proyectos del cuerpo legislativo se convirtieran en leyes o que quedaran sujetas a suspensión. ${ }^{212}$

Fue esta última argumentación la que convenció a la Asamblea, que adoptó el artículo 2o., del título III en los siguientes términos: "la Nación, de la que únicamente emanan todos los poderes, no los puede ejercer más que por delegación. La constitución francesa es representativa: los representantes son el cuerpo legislativo y el Rey".

Bajo el antiguo régimen, los bienes del Estado eran bienes del rey. La Constitución adoptó la regla inversa, los artículos 9o., 10 y 11 del título III, capítulo II, sección la. dispusieron que, en adelante, todos los bienes del rey serían devueltos a la nación y que recibiría un salario, de una lista civil determinada por el cuerpo legislativo.

\footnotetext{
210 Cfr. Troper, Michel, La separation des pouvoirs..., cit., pp. 32 y 33.

211 Ibidem.

212 Ibidem.
} 
Este libro forma parte del acervo de la Biblioteca Jurídica Virtual del Instituto de Investigaciones Jurídicas de la UNAM

\section{LA SEPARACIÓN DE LOS PODERES}

\section{El artículo 16 de la Declaración de los Derechos del Hombre y del Ciudadano}

El principio de separación de poderes, tal como fue entendido en la Asamblea Constituyente de 1789, era totalmente ajeno al derecho público de la monarquía absoluta francesa. La regla esencial del derecho público del Antiguo Régimen se fundaba, en efecto, en la concentración de todas las funciones del Estado en manos del rey. Como se ha dicho, la fórmula con la que el monarca francés rubricaba y cerraba tanto decretos como órdenes, y con las que se enfatizaba que la única voluntad que contaba era la de él: car tel est notre plaisir o bien si veut le roi, si veut la loi, no son sino manifestaciones elocuentes de esta centralización altísima de poderes, facultades y competencias en la persona del monarca, todavía vigente en la víspera del estallido de la Revolución.

Con todo, esto no fue obstáculo para que en diversos momentos de la historia política de Francia no se solicitara en el seno de los Estados Generales el establecimiento de límites al despotismo creciente del poder real. Pero la idea de separación de los poderes, en el sentido adoptado en 1789, no fue en manera alguna bandera reivindicada antes de esa fecha. Para probarlo, Duguit establece un inventario erudito de ordenanzas, memoriales de agravios, etcétera, donde no aparece nada que se parezca a la noción de separación de poderes. ${ }^{213}$

Más sorprendente aún es que ni en los mismos cahiers de doleánces de 1789 se encuentre nada que prepare o sirva de antecedente a la teoría de la separación de poderes: se recogió, sí, el rechazo contra el absolutismo real; sin embargo, no había referencia alguna de la separación de poderes.

A decir de Duguit no fue, ni en las instituciones del país ni en los memoriales de agravios de los antiguos Estados Generales, ni

213 Duguit, Leon, La separación de poderes.., cit., pp. 7-9. 
Este libro forma parte del acervo de la Biblioteca Jurídica Virtual del Instituto de Investigaciones Jurídicas de la UNAM

en las reivindicaciones de los parlamentos, ni siquiera en los $c a-$ hiers de 1789, donde los diputados constituyentes encontraron la teoría de la separación de poderes que llevaron al nivel de principio o dogma, sino que fue a través de Montesquieu, en la Constitución inglesa y en la Constitución norteamericana. ${ }^{214}$ Veamos más de cerca estas influencias.

El espiritu de las leyes formaba parte del clima intelectual de la época y, por tanto, no es difícil explicar porqué inspiró a las mejores cabezas de la Asamblea Constituyente y porque, de la mejor buena fe, se creyó reproducir fielmente sus doctrinas.

La Constitución norteamericana de 1787 tuvo un lugar importante en las deliberaciones de la Constituyente, pero la juzgaron y conocieron con la ayuda de dos obras debidamente traducidas, que tuvieron gran resonancia en esta época en Francia, el libro de John Adams Histoire de la Querelle entre la Grande Bretagne et les Colonies Americaines. Defense de la Constitution et du Gouvernement des Etats-Unis, de 1787215 y el de Robert Livingston, Examen du Gouvernement d'Angleterre Comparé aux Constitutions des Etats Unis, de 1789.

Así, ya desde el 9 de julio de 1789, en el reporte hecho a nombre de la Comisión encargada de la redacción de la Constitución, Mounier apuntaba la relación entre constitución y separación de poderes: “...no tenemos una constitución, puesto que todos los Poderes están confundidos, puesto que ningún límite ha sido trazado. Ni siquiera se ha separado al Poder Judicial del Poder Legislativo...".216 Idea que iría a ser reforzada por Sieyès unos días después en su propuesta de declaración de derechos: “...tal es el verdadero sentido de la palabra constitución; es relativa al conjunto y a la separación de los Poderes públicos...". ${ }^{217} \mathrm{Al}$

214 Ibidem, pp. 10 y 11.

215 El título original $A$ defence of the constitutions of government of the United States of America, againts the attack of $M$. Turgot, in his letter to Dr. Price, dated the twenty second of March 1778, en Adams, John, Écrits Politiques et Philosophiques, Caen Presses Universitaires de Caen, vols. I y II, 2004.

216 Mounier, "Rapport de Mounier...," cit., p. 313.

217 Sieyès, Emmanuel-Joseph, "Preliminar de la Constitución..., cit., p. 183. 
Este libro forma parte del acervo de la Biblioteca Jurídica Virtual del Instituto de Investigaciones Jurídicas de la UNAM

parecer, la idea que se va gestando en el seno de la Asamblea Nacional no sólo es la de la liga indisoluble entre Constitución y principio de separación de poderes, sino también, la vinculación entre este principio y los derechos humanos.

Como ya ha sido relatado, en plena euforia de la noche del 4 de agosto, la Asamblea Constituyente decidió por aclamación que la Constitución fuera precedida de una declaración de derechos. Desde luego que el texto definitivo no estaba todavía establecido, particularmente no lo estaba el artículo relativo al principio de separación de poderes. Como ya se ha dicho, la extendida lectura y aceptación del Espiritu de las leyes le había hecho entrar al patrimonio cultural común, por lo que había un generalizado acuerdo sobre el principio; fue, entonces, la fórmula para consagrarlo la que sería objeto de largas discusiones.

Ya en otra sección ha habido oportunidad de referirse a los proyectos de declaración presentados a las diferentes comisiones formadas para su redacción y a diversas intervenciones habidas en su discusión. Sieyès, por ejemplo, no tiene ni en su proyecto de declaración del 20 y 21 de julio, ni en el del 12 de agosto una propuesta de artículo en que se consagre este principio.

La moción que el Marqués de La Fayette presentó el 11 de julio de 1789 expresaba: "todo gobierno tiene por fin único el bien común. Este interés exige que los Poderes Legislativo, Ejecutivo y Judicial sean distintos y definidos. ${ }^{218}$

El 28 de julio de 1789, Mounier leyó en la sesión de la Asamblea Nacional el proyecto de los primeros artículos de la Constitución. Así, decía el artículo XIV, "para prevenir el despotismo, y asegurar el imperio de la ley, los Poderes Legislativo, Ejecutivo y Judicial deben ser distintos. Su reunión en las mismas manos pondría a los que fueran sus depositarios por encima de todas las leyes y les permitirían substituirlas por sus voluntades". 219

Target presentó un proyecto de declaración que contenía, entre otros, el artículo XXX que decía, "la constitución es buena

218 Fauré, Christine, op. cit., p. 89.

219 Ibidem, p. 113. 
Este libro forma parte del acervo de la Biblioteca Jurídica Virtual del Instituto de Investigaciones Jurídicas de la UNAM

si los Poderes están de tal manera organizados que no puedan ni confundirse, ni usurparse el uno al otro, y si la fuerza ejecutora es, a la vez, suficientemente grande para que nada pueda detener su acción legítima y suficientemente subordinada a la potestad legislativa, para que los agentes del orden supremo no puedan violar impunemente las leyes". ${ }^{220}$ Rabaut Saint-Étienne señalaba en el artículo $\mathrm{V}$ de su proyecto de declaración que "los diferentes Poderes deben estar confiados a diferentes personas".221

El proyecto que se tomó como base para la discusión que fue presentado por la Comisión Sexta, presidida por Champion de Cicé, contenía en el artículo 24 el texto siguiente: "toda sociedad en la cual la garantía de derechos no está asegurada y la separación de Poderes determinada no tiene una verdadera constitución". Esta formulación dio lugar a vivas discusiones y a propuestas alternativas. Existieron algunas objeciones como las de Robespierre, a que el principio de separación de poderes estuviera situado en la Declaración de derechos y no en la Constitución misma, a lo que se replicó que no se trataba sólo de los derechos del hombre, sino de los del hombre en sociedad, del ciudadano. ${ }^{222}$

El texto finalmente aprobado no difiere prácticamente de la redacción del proyecto de la Comisión: "toda sociedad en la cual la garantía de los derechos no está asegurada, ni la separación de los Poderes determinada, carece de constitución”. Ahora bien, ¿Cómo interpretaron los diputados constituyentes ese artículo?, ¿qué relación tenía con lo expresado por El espiritu de las leyes?, ¿cómo recogió este principio la Constitución de 1791 en las relaciones entre los poderes?, ¿cómo fue traducido posteriormente por la doctrina constitucional tradicional? Trataré de dar respuesta a estos planteamientos en los apartados subsecuentes.

220 Ibidem, p. 127.

221 Ibidem, p. 342.

222 Duguit, Leon, La separación de poderes.., cit., p. 23. 
Este libro forma parte del acervo de la Biblioteca Jurídica Virtual del Instituto de Investigaciones Jurídicas de la UNAM

\section{Montesquieu y la separación de poderes}

El nombre de Montesquieu está indisolublemente ligado al principio de la separación de poderes y en la doctrina constitucional clásica la mención de su nombre evoca indefectiblemente ese principio capital en el constitucionalismo moderno.

En efecto, una interpretación o forma de leer el Espiritu de las leyes, prevaleciente durante parte del siglo XIX y principios del XX - entre cuyos autores podemos citar a Esmein, Laferrière, Barthelemy y Carré Malberg - pretende que su diseño consiste en confiar las funciones estatales a autoridades o grupos de autoridades absolutamente distintas e independientes, esto es, en instituir tres autoridades o grupos de ellas perfectamente separadas de manera total. En primer término, separadas funcionalmente ya que cada autoridad ejercería, con plena independencia, de manera íntegra a la vez que exclusiva, una función estatal. También, separadas en lo personal, ya que no podrían revocarse unas a otras y materialmente por la prohibición de tener relación, contacto o comunicación entre sí. ${ }^{223}$

Un dato curioso es que, a pesar de que se le hubiera formulado a esta interpretación una crítica demoledora que la aniquila por errónea en su validez como doctrina, siga siendo enormemente difundida. Efectivamente, Eisenmann en un trabajo importantísimo demostró cómo en el capítulo VI del libro XI del Espiritu de las leyes, dedicado a la Constitución de Inglaterra, no se encuentra ni la separación funcional ni la separación material en que se funda la doctrina clásica.

En efecto, una lectura más atenta permite constatar que no es exacto que en el esquema de Montesquieu se confiara el ejercicio de cada una de las facultades de manera exclusiva a una autoridad o grupo de autoridades absolutamente distinto,

223 Eisenmann, Charles, "El espíritu de las leyes y la separación de poderes", Anuario furídico, México, núm. 2, 1975, pp. 429 y ss. 
Este libro forma parte del acervo de la Biblioteca Jurídica Virtual del Instituto de Investigaciones Jurídicas de la UNAM

por la simple razón que no era así como funcionaban las instituciones políticas británicas. Trataré de probarlo, remitiéndome al texto.

La facultad de expedir reglas legislativas estaba confiada no sólo al Parlamento, sino conjuntamente éste y al gobierno, pues el rey tenía derecho de veto. Se debe recordar que Montesquieu distinguía la facultad de "estatuir" — que era el derecho de ordenar por sí mismo o de corregir lo que había sido ordenado por otro - de la facultad de "impedir" - que era "el derecho de anular una resolución tomada por algún otro". La reflexión que al respecto se hacía Montesquieu es la siguiente:

...la potestad ejecutiva como hemos dicho, debe tomar parte en la legislación, por su facultad de impedir, sin la cual sería muy pronto despojada de sus prerrogativas ...si el monarca tomara parte en la legislación por su facultad de estatuir, no habría libertad. Pero como, no obstante, es menester que tome parte en la legislación para defenderse, es necesario que tome parte en ella por la facultad de impedir. ${ }^{224}$

Por otra parte, si bien la facultad ejecutiva estaba totalmente encomendada al gobierno, Montesquieu le reconocía al Parlamento el derecho y la facultad de examinar la forma en que eran ejecutadas las leyes que había expedido. Después de señalar el inconveniente de que la potestad legislativa tuviera recíprocamente la facultad de detener a la ejecutiva, ya que "la ejecución tiene por naturaleza sus limitaciones" - agregó - "pero si en un Estado libre la potestad legislativa no debe tener el derecho de detener a la potestad ejecutiva, tiene el derecho y debe tener la facultad de examinar de qué manera han sido ejecutadas las leyes que hizo". ${ }^{225}$

En fin, si la facultad jurisdiccional estaba confiada a los tribunales, Montesquieu estimaba que, bajo ciertas circunstancias, el

\footnotetext{
224 Montesquieu, op. cit., pp. 588 y 589.

225 Ibidem, p. 589.
} 
Este libro forma parte del acervo de la Biblioteca Jurídica Virtual del Instituto de Investigaciones Jurídicas de la UNAM

conocimiento de ciertos procesos podría pertenecer al Parlamento. Así, expresó lo siguiente:

Aunque, en general, la potestad de juzgar no deba estar unida a ninguna parte de la legislatura, ésta debe estar sujeta a tres excepciones, fundadas en el interés particular de aquél que debe ser juzgado. Los grandes están siempre sujetos a la envidia y si fueran juzgados por el pueblo, podían estar en peligro... Es necesario, entonces, que los nobles sean llamados, no ante los tribunales ordinarios de la Nación, sino ante esa parte del cuerpo legislativo que está compuesta de nobles.

También preveía que cuando la ley era demasiado rigurosa se pudiera acudir al cuerpo legislativo, a fin de que como autoridad suprema moderara "la ley a favor de la ley misma, pronunciándose menos rigurosamente que ella. Y, finalmente, visualizaba un tercer caso:

Podría también ocurrir que, en asuntos públicos, cualquier ciudadano violara los derechos del pueblo y cometiera crímenes que los magistrados no pudieran o no quisieran castigar. Empero, en general, la potestad legislativa no puede juzgar y lo puede todavía menos en ese caso particular en que representa a la parte interesada que es el pueblo. No puede ser, en consecuencia, más que acusadora. Pero, ¿̇ante quién acusará?... para conservar la dignidad del pueblo y la seguridad del particular, es necesario que la parte legislativa del pueblo acuse ante la parte legislativa de los nobles, la cual no tiene ni los intereses, ni las mismas pasiones que ella. ${ }^{226}$

En el sistema de Montesquieu no estaban en absoluto separados funcionalmente los poderes, ya que ninguna de las autoridades era titular de la totalidad de una función, dueña exclusiva de esa función y especializada en esa única función.

Ahora bien, según lo ha probado Eisenmann, de igual forma era inexacto afirmar que las autoridades no recibían ningún

226 Idem. 
Este libro forma parte del acervo de la Biblioteca Jurídica Virtual del Instituto de Investigaciones Jurídicas de la UNAM

medio de actuar las unas sobre las otras, pues Montesquieu reconocía la facultad del gobierno de convocar al Parlamento y aún de prorrogar la duración de sus sesiones. ${ }^{227}$ En efecto, empezaba nuestro autor por enumerar los inconvenientes que veía en que el cuerpo legislativo tuviera facultades para convocarse a sí mismo a sesionar, por lo que concluía: "es menester, en consecuencia, que sea la potestad ejecutiva la que regule el tiempo de la convocatoria y la duración de esas asambleas en relación a las circunstancias que conoce". 228

Tampoco era correcto afirmar que Montesquieu hubiera deseado la separación material de todos los órganos estatales, desde el momento en que los ministros deberían dar cuenta de su administración y justificar su conducta frente al Parlamento. Después de considerar inviolable a la persona del monarca, porque era necesaria su persona para que el cuerpo legislativo no se convirtiera en tiránico y desde el momento en que pudiera ser acusado o juzgado no habría libertad y agregaba: "pero como aquél que ejecuta no puede ejecutar mal sin tener consejeros malvados, que odian a las leyes como ministros, aunque les favorezcan como hombres, éstos pueden ser juzgados y castigados". 229

Por otras razones, igualmente importantes que las anteriores, extraídas de la lectura directa de Montesquieu, Eisenmann puso también en claro el abismo que mediaba entre el sistema previsto en El espiritu de las leyes y el régimen de separación de poderes que se le atribuía.

Se planteaba, en primer término, de qué manera hubiera sido posible conciliar la idea de una separación de poderes, con el sistema del Espiritu de las leyes, cuando al sintetizar el aspecto general de la Constitución que Montesquieu consideraba como deseable, afirmaba que el cuerpo legislativo y el gobierno deberían estar encadenados, ligados por sus facultades mutuas:

227 Eisenmann, Charles, op. cit., pp. 434 y 435.

228 Montesquieu, op. cit., p. 588.

229 Ibidem, p. 589. 
Este libro forma parte del acervo de la Biblioteca Jurídica Virtual del Instituto de Investigaciones Jurídicas de la UNAM

He aquí la constitución fundamental del gobierno de la que hablamos, dice el autor de Cartas persas, estando el cuerpo legislativo compuesto de dos partes, una encadenaría a otra por su facultad mutua de impedir. Las dos estarán ligadas por la potestad ejecutiva, que lo será ella misma por la legislativa. Estas tres potestades deberán formar un reposo o una inacción. Pero como, por el movimiento necesario de las cosas, están constreñidas a marchar, estarán forzadas a ir de concierto. ${ }^{230}$

Este párrafo haría exclamar a Eisenmann: “iqué prodigio que una separación desembocara en una fusión o ligazón, o que una fusión o ligazón se realizara por medio de una separación!'”.231

Seguidamente, si una de las ideas centrales o la idea central en Montesquieu es la de disponer las cosas de tal suerte que el poder detenga al poder, esto es, que todo órgano político encuentre a otro órgano que pueda oponerse a su voluntad, impidiéndole que la imponga, ¿de qué manera sería conciliable esta idea con la de la separación y la de la especialización funcional? Si esto fuera así — nos dice Eisenmann - Montesquieu habría ideado el absurdo de concebir que el mejor medio de lograr que dos órganos se limitaran mutuamente sería el de encerrarlos en actividades independientes, o cuando menos distintas, que ejercerían libre y soberanamente, fuera de toda influencia y de todo control el uno del otro. ¿No parecería que entre la idea de especialización funcional, a fortiori de separación funcional, y la idea de limitación mutua existía una incompatibilidad lógica absoluta?232

Los pasajes de Montesquieu donde se ha querido ver la separación de poderes son aquellos en que se refiere a la libertad política y a las circunstancias que la ponen en peligro, en especial, el párrafo con el que remata su reflexión donde señala que "todo estaría perdido si el mismo hombre o el mismo cuerpo de los principales o de los nobles o del pueblo ejercieran esos tres pode-

230 Idem.

231 Eisenmann, Charles, op. cit., p. 436.

232 Ibidem, pp. 436 y 437. 
Este libro forma parte del acervo de la Biblioteca Jurídica Virtual del Instituto de Investigaciones Jurídicas de la UNAM

res: el de hacer las leyes, el de ejecutar las resoluciones públicas y el de juzgar los crímenes o los diferendos de los particulares". ${ }^{233}$ Pero, como bien lo señalaba Eisenmann, estos pasajes:

...de ninguna manera significan que una misma autoridad - individuo o cuerpo - no deba participar más que de una función, tener atribuciones de una sola especie, no ser miembro de dos órganos u órgano de dos formaciones y, por consiguiente, que los órganos de dos de las funciones o de las tres no deban tener ningún elemento en común, sino, en forma sencilla y mucho más modestamente, que no es necesario que dos, cualesquiera que sean, de las tres funciones estén reunidas íntegramente en las mismas manos. ${ }^{234}$

En conclusión, es preciso dejar sentado que los hombres del siglo XVIII no concibieron la separación de poderes de la misma manera que lo hizo la doctrina constitucional clásica de fines del siglo XIX y principios del XX: en el modelo de Constitución inglesa que describe Montesquieu no aparecen ninguna de las dos reglas que caracterizarían a la separación de poderes, según los autores clásicos, pues no está presente ni la especialización, ni la independencia, ya que ninguno de los poderes ejerce la totalidad de una función de manera exclusiva y especializadamente, como se ha mostrado.

Igualmente, parece necesario señalar que en la separación de poderes estaba implícita la igualdad de las funciones estatales. En el ánimo de encontrar el equilibrio entre éstos, en la doctrina clásica, en efecto, estaba presente la idea de la equivalencia entre las funciones legislativa y ejecutiva. Si las funciones, por lo contrario, se concibieran como jerarquizadas, entonces estaría excluido que se pudiera esperar un equilibrio entre autoridades especializadas.

Este era el caso en el siglo XVIII, porque se debe recordar la intervención de Mirabeau cuando afirmaba que la Constitu-

\footnotetext{
233 Montesquieu, op. cit., p. 586.

234 Eisenmann, Charles, op.cit., pp. 438 y 439.
} 
Este libro forma parte del acervo de la Biblioteca Jurídica Virtual del Instituto de Investigaciones Jurídicas de la UNAM

ción no estaba hecha para equilibrar los poderes, sino para subordinarlos, pues el poder soberano de la nación no podría estar sometido al poder del rey o al de una corporación de nobles o de curas. ${ }^{235}$ En coincidencia notoria en el mismo sentido, Sieyès y Mirabeau distinguían la facultad de querer de la facultad de actuar, representando el Poder Legislativo a la primera de estas facultades y el Poder Ejecutivo a la segunda. ${ }^{236}$ De manera inequívoca dejó sentado Sieyès, en otro párrafo, la superioridad del Poder Legislativo, "la otra rama de la Constitución pública, hemos dicho, es la constitución del Poder Legislativo que es, en el orden de las necesidades y derechos de toda sociedad pública, el primero y más importante de todos..."..237 De alguna forma, estas ideas coincidían con una metáfora antropomórfica muy en boga en el siglo XVIII que representaba a la sociedad o al Estado como un cuerpo en el que la cabeza era el Poder Legislativo que mandaba y el Poder Ejecutivo el brazo, que no hacía sino cumplir los actos materiales exigidos por esta voluntad. A nadie escapa que en estas ideas está presente la subordinación de la función ejecutiva. ${ }^{238}$

En la Asamblea Constituyente, particularmente en el momento de votarse el artículo 16 de la Declaración de Derechos del Hombre, no fue concebida la separación de poderes en el sentido que en el siglo XIX hizo suya la doctrina constitucional clásica. Si la separación de poderes hubiera implicado un sistema en el que los órganos fueran especializados y jerarquizados se habrían polarizado los puntos de vista. ¿Cómo explicarse, entonces, que el texto del artículo 16 hubiera sido aprobado sin debate y casi unánimemente, teniendo en consideración que en agosto de

235 Véase las notas 6 y 61 de este trabajo.

236 Para Mirabeau, véase nota 189 de este trabajo. Para Sieyès $c f r$. "Preliminar de la Constitución...", cit., p. 182.

237 Sieyès, Emmanuel-Joseph, "Consideraciones sobre los medios...", cit., p. 102.

238 Cfr. Troper, Michel, Pour une théorie juridique de l'État, París, PUF, Leviathan, 1994, pp. 226 y 227. 
Este libro forma parte del acervo de la Biblioteca Jurídica Virtual del Instituto de Investigaciones Jurídicas de la UNAM

1789 aún se encontraban sin resolver numerosos aspectos de la Constitución?

La única explicación posible reside en que sobre el significado de la separación de poderes hubiera un consenso amplio. Efectivamente, en numerosos textos, incluido El espiritu de las leyes, el principio de separación de poderes entrañaba un sistema en el cual éstos estaban simplemente repartidos en varias autoridades u órganos. Se trataba de un principio puramente negativo: un mismo órgano no debía acumular todos los poderes. Este principio era fácilmente justificable, puesto que la concentración de poderes en unas solas manos corría el peligro de convertir en un déspota al titular, que gobernaría según su capricho y en su interés personal. $\mathrm{Al}$ contrario, si las competencias fueran repartidas entre varias autoridades y si el que ejecutara la ley no tuviera facultades para hacerla o modificarla en el momento de la aplicación, no podría actuar, ni ordenar más que en virtud de una ley anterior. Al obedecer, no se obedecería a un hombre sino a la ley, en otras palabras, los ciudadanos serían libres, según la concepción de libertad antes expuesta. En realidad, nadie se podía oponer a lo que no era sino el rechazo al despotismo o, aún más, a la simple definición de Constitución que, según hemos visto, era una repartición de competencias. 239

\section{El principio de la separación de los poderes \\ y el diseño de las instituciones políticas}

La Constitución de 1791 estaba atravesada por una tensión, producto de la actitud ambivalente que caracterizó la evolución del trabajo colectivo que dio cima a ese instrumento de gobierno. La primera constitución francesa estaba fundada, en efecto, en un derecho natural de nuevo cuño, que se expresaba en la adopción de la idea de soberanía nacional, por una parte y, por otra, sobre un derecho histórico que no se abandonaba totalmente,

239 Idem. 
Este libro forma parte del acervo de la Biblioteca Jurídica Virtual del Instituto de Investigaciones Jurídicas de la UNAM

puesto que la monarquía se mantenía con la ley sálica de la sucesión al trono.

De la lectura de esa enorme cantidad de panfletos y publicaciones que aparecen entre 1788 y 1789, se puede constatar que la preocupación que asediaba a los espíritus de la época era el aspecto social de la igualdad, el de la supresión de los privilegios, el de la abolición de los órdenes estamentales y que, generalmente, se tenían puntos de vista precisos sobre los derechos que asistían al Tercer Estado en los Estados Generales y que, en cambio, sobre la cuestión de la organización política propiamente dicha y, más particularmente, sobre la cuestión de la organización constitucional las ideas estaban aún muy desdibujadas.

Por otra parte, en este dominio no se había impuesto una línea de pensamiento u opinión que dominara. Mucho se había leído y más discutido l'Esprit des Lois o Le Contrat Social; la guerra de independencia norteamericana había seducido y ejercido su influencia en muchos círculos, pero, de estas obras y de este acontecimiento, se podían hacer lecturas variadas y divergentes, pues al fin y al cabo l'esprit du siècle se nutría de legados a menudo contradictorios. En los Estados Unidos encontraban el ejemplo republicano y de una organización de las instituciones políticas basada en una separación rígida de poderes iguales. Por su parte, aunque la lógica de El contrato social fuera republicana, no admitía ni la separación de poderes, ni la equiparación de los mismos ya que fincado en la soberanía popular que exaltaba al Legislativo, era hostil al Ejecutivo. Y, finalmente, no obstante que de El espiritu de las leyes se pudieran hacer distintas lecturas, de sus páginas se desprendía como el más admirado modelo, el del gobierno inglés. ${ }^{240}$

Es en este marco y teniendo como antecedente las discusiones materia de análisis anteriores es que se diseñaron las instituciones políticas en la Constitución de 1791. El título III dedicado a los poderes públicos empezó por una declaración contenida en el artículo 1o. (base a partir de la cual se erigen las instituciones).

240 Chevallier, Jean-Jacques, op. cit., pp. 41 y 42. 
Este libro forma parte del acervo de la Biblioteca Jurídica Virtual del Instituto de Investigaciones Jurídicas de la UNAM

"La soberanía es una, indivisible, inalienable e imprescriptible. Pertenece a la nación; ninguna sección del pueblo, ningún individuo puede atribuirse su ejercicio". A su vez el artículo 20. adoptó el sistema representativo como consecuencia ineluctable de haberse consagrado la idea de soberanía nacional, "la $\mathrm{Na}$ ción de la que únicamente emanan todos los Poderes, no puede ejercerlos más que por delegación. La constitución francesa es representativa: los representantes son el cuerpo legislativo y el Rey". En los artículos subsecuentes, 3o., 4o. y 5o., respectivamente, se resume una de las aportaciones más importantes que, como ha sido dicho, hiciera la Asamblea Constituyente al derecho público. Se trata de la "delegación de poderes", que concibe a la Nación como "titular originaria" de todas las facultades y poderes y quien, por medio de la constitución, "delega solamente el ejercicio" de esas facultades y poderes a los órganos del Estado, "el Poder Legislativo es "delegado" a una Asamblea Nacional, compuesta de representantes temporales, libremente electos por el pueblo, para ser ejercido por ella, con la sanción del Rey, de la manera que será determinada más adelante...", "el gobierno es monárquico: el Poder Ejecutivo es delegado al Rey, para ser ejercido, bajo su autoridad, por ministros y otros agentes responsables, de la manera que será determinada más adelante...", "el Poder Judicial es delegado a jueces electos temporalmente por el pueblo".

Como ya se ha visto, otra consecuencia de la adopción de la idea de soberanía nacional y del sistema representativo fue la exclusión del mandato imperativo, concordante con la concepción de que los diputados representaban a la nación. Así, es dispuesto por el artículo 7o., del título III, capítulo 1 ro, sección III, "los representantes nombrados en los departamentos no serán representantes de un departamento en particular, sino de la Nación entera y no les podrá ser dado ningún otro mandato".

Ha sido también objeto de análisis el razonamiento por el que concatenado a la idea de soberanía nacional y de sistema representativo, se concibió al voto como una función y no como un derecho. Esta concepción tuvo efectos no sólo conceptuales: 
Este libro forma parte del acervo de la Biblioteca Jurídica Virtual del Instituto de Investigaciones Jurídicas de la UNAM

la distinción que como consecuencia desprendió Sieyès y que recogió la Constituyente en el artículo 2o. del título III, capítulo 1ro, sección II, entre ciudadanos pasivos y ciudadanos activos, excluía a una parte considerable de la población, pues no tenían acceso al sufragio las mujeres, los menores de veinticinco años, los que estuvieran en estado de domesticidad y no acreditaran haber pagado una contribución directa, al menos igual al valor de tres jornadas de trabajo.

En la Constitución de 1791 se consagró una ambigüedad, entre universal y censitaria, en materia de sufragio. Se calcula que en esa época había veintisiete millones de habitantes aproximadamente en Francia y que de éstos, seis millones eran potenciales votantes, por ser varones, de más de veinticinco años; sin embargo, sólo podían votar cuatro y medio millones. A pesar de las condiciones restrictivas y de sus justificaciones, que descartaban a este tercio de la población, los constituyentes se inscribían en una concepción universalista de la ciudadanía y es que la condición que implicaba el pago del equivalente a tres jornadas de trabajo para poder votar no tenía para los constituyentes un sentido censitario, pues, sólo un pequeño número de personas quedaba excluido por esta razón. Debemos recordar que, en su informe sobre el proyecto de Constitución del 29 de septiembre de 1789, Thouret subordinaba el ejercicio del sufragio a varias condiciones tales como la nacionalidad, el domicilio y el pago de los impuestos, entre otros. En el debate se añadieron otras más, como la de la conformidad a la ley; es decir, eran excluidos los que habían contrariado las reglas de la vida social: a los quebrados y a los condenados a penas infamantes. Finalmente, a estas constricciones se añadieron la pérdida de la ciudadanía por juicio de contumacia, en tanto el juicio no fuera anulado. Además, se exigía para ser ciudadano activo no estar en estado de domesticidad y se prescindía del ejercicio de los derechos de la ciudadanía activa a los acusados y a los que habiendo sido constituidos en estado de quiebra o de insolvencia no demostraran haber satisfecho a sus acreedores. A pesar de todo esto, la principal causa 
Este libro forma parte del acervo de la Biblioteca Jurídica Virtual del Instituto de Investigaciones Jurídicas de la UNAM

de exclusión fue la de no cumplir la condición de estar domiciliado en la ciudad o cantón respectivos, desde el tiempo que la ley señalara, lo que tenía por objeto alejar de la ciudadanía activa a los que no tenían un lazo fijo en la comunidad. Esta condición no afectaba a campesinos, obreros o artesanos, sino que eran las clases marginales o inestables las que quedaron excluidas. Fue esta condición la que sustrajo del cuerpo electoral a ese tercio de hombres en edad de voto. ${ }^{241}$

Además, del sufragio censitario, una precaución más fue concebida para filtrar la voluntad expresada en las urnas. La elección de diputados no era directa sino que, de acuerdo a los artículos del 1o. al 7o., del título III, capítulo 1, sección II, los ciudadanos activos, constituidos en asambleas primarias, optaban por electores, quienes serían los que elegirían a los representantes en la Asamblea Nacional. Ahora bien, para ser elector además de las condiciones requeridas para ser ciudadano activo, era indispensable ser propietario, usufructuario o granjero de un bien equivalente al valor local de ciento cincuenta a cuatrocientas jornadas de trabajo, según la importancia de las comunas. Y aunque se exigía un censo más alto para los electores, éstos podían escoger como diputados a cualquier ciudadano activo sin distinción. Con semejante sistema electoral, Francia - que en la época tenía veinticinco millones de habitantes - contaba con alrededor de cuatro millones trescientos mil ciudadanos activos, sobre aproximadamente siete millones de ciudadanos, excluyendo a las mujeres, y el número de electores en segundo grado era aún más restringido, sin duda, apenas alcanzaría a unos cincuenta mil en todo el país. ${ }^{242}$

En la base de la construcción de las instituciones políticas, en especial de la de los poderes Legislativo y Ejecutivo y de sus rela-

241 Rosanvallon, Pierre, La consagración del ciudadano..., cit., pp. 41, 67, 73, 74 y 84. Esta causal de exclusión tiene que ver, a mi juicio, con una visión corporativa, propia de una cultura del Antiguo Régimen que asimilaba la condición de ciudadano a la de vecino, en tanto perteneciente a un cuerpo.

242 Godechot, Jacques, Les institutions de la France sous la Revolution et L'Empire, París, PUF, 1951 p. 74. 
Este libro forma parte del acervo de la Biblioteca Jurídica Virtual del Instituto de Investigaciones Jurídicas de la UNAM

ciones, se debe tener en cuenta que la Asamblea Constituyente se asumía como titular del poder constituyente de la nación que, según la elaboración de Sieyès, lo concebía como omnímodo, y en esa línea de ideas, tendió a conceder al Legislativo las atribuciones más extensas. ${ }^{243}$ Por otra parte, la historia de la relación entre el rey y la Asamblea ha sido resumida como "una confrontación caótica y traqueteada entre dos desconfianzas", ${ }^{244}$ lo que movió a ésta a erigir de la separación de poderes "una maquinaria de guerra" contra el rey, según la expresión de otro autor. ${ }^{245}$

Ya ha habido ocasión de referirse a los argumentos con los que contendieron en la Asamblea Constituyente los que sostenían el bicamarismo contra los partidarios del monocamarismo. $\mathrm{Al}$ triunfo de esta última tendencia, la comisión encargada de la redacción de la Constitución renunció junto con los partidarios del bicamarismo: Mounier, Bergasse, Champion de Cicé, Lally-Tollendal y Clermont-Tonerre, y fueron reemplazados por Thouret, Target, Tronchet, Desmeuniers y Rabaut-Saint-Etienne, como ya fue dicho.

Conformada por una sola Cámara, la Asamblea Nacional estaba regulada en el título III, capítulo 1, donde se señalaba en sus cuatro artículos que sería renovada mediante elecciones cada dos años, formándose una legislatura cada periodo, que dicha renovación tendría lugar de pleno derecho, una vez que expirara la legislatura. Con estos elementos y con la prohibición al rey de disolver la Asamblea, se aseguraba no sólo su carácter permanente sino también su preeminencia.

Su composición y las bases de representación estaban consignadas en el título I, capítulo 1, sección I, en sus cinco artículos que disponían una representación amplia de setecientos cuarenta y cinco diputados, repartidos en ochenta y tres departamentos, de manera proporcional a tres factores: intereses locales, pobla-

243 Ibidem, p. 75.

244 Chevallier, Jean-Jacques, op. cit., p. 32.

245 Godechot, Jacques, Les institutions..., cit., p. 119. 
Este libro forma parte del acervo de la Biblioteca Jurídica Virtual del Instituto de Investigaciones Jurídicas de la UNAM

ción e intereses financieros, de suerte que cada departamento asegurara por lo menos cinco diputados.

Los artículos 7o. y 80. del título III, capítulo 1, sección V regulaban la inmunidad de los diputados, disponiendo su inviolabilidad, pues no podían ser buscados, acusados ni juzgados, en ningún tiempo, por lo dicho, escrito o hecho en el ejercicio de sus funciones de representantes. No obstante, podían ser aprehendidos por hechos criminales, en flagrante delito o por virtud de una orden de arresto, pero debería ser dado aviso al cuerpo legislativo y el procedimiento no podría continuar, sino hasta que éste hubiera decidido que había lugar a la acusación.

La independencia del Poder Legislativo se aseguraba por diversos medios. Los tres primeros artículos del título III, capítulo 1, sección $\mathrm{V}$, disponían que una vez electos, los diputados debían reunirse el primer lunes de mayo en el lugar de las sesiones de la última legislatura, conformándose provisionalmente como asamblea y bajo la presidencia del representante de más edad, con objeto de proceder a la verificación de poderes de los presentes. Una vez verificados los poderes de los primeros trescientos setenta y tres miembros se constituían en Asamblea Nacional legislativa, nombrándose un presidente, un vicepresidente y secretarios para comenzar a ejercer sus funciones. En otros términos, la verificación de poderes llevada a cabo por la propia cámara era concebida como la mejor garantía de que ningún otro poder o institución política intervendría en su conformación y establecimiento y, por supuesto, una consecuencia consistía en que la Asamblea se daba su propia organización. La independencia de la Asamblea se manifestaba también en el libre manejo de sus sesiones, suspendiéndolas o reuniéndose, según su libre arbitrio, bastando con que se le hiciera saber al rey. Sin embargo, éste podría convocarla en el intervalo de las sesiones, si así lo exigía el interés del Estado, según lo disponían diversos artículos del título III, capítulo 3, sección IV.

Tanto la separación de poderes como su independencia recíproca se expresaban en disposiciones distintas contenidas en los 
Este libro forma parte del acervo de la Biblioteca Jurídica Virtual del Instituto de Investigaciones Jurídicas de la UNAM

artículos 6o., 8o. y 10 del título III, capítulo 3, sección IV. El rey podía asistir al lugar de las sesiones del cuerpo legislativo, pero no podía ser acompañado al interior de la sala más que por el príncipe real y los ministros. Éstos podían ser admitidos y escuchados, cada vez que se les preguntara por el objeto de su administración y para hacer aclaraciones, igualmente lo serían para otros temas, siempre que la Asamblea les concediera la palabra. Sin embargo, la Asamblea legislativa cesaría de ser cuerpo deliberante, mientras el rey estuviera presente.

En diversos artículos del título III, capítulo III, sección 1ra, confirió la Constitución al cuerpo legislativo el ámbito de sus atribuciones. En primer término, le fueron delegadas las facultades de proponer y decretar las leyes. El temor a que el rey abusara de su prestigio e indujera a votar disposiciones contrarias al sentir de la Asamblea, condujo a la Constituyente a privarlo de la facultad de iniciativa legislativa y sólo le concedió la posibilidad de invitar al cuerpo legislativo a tomar en consideración algún tema. Otras facultades de gran importancia y que, en opinión de un autor, son más propiamente ejecutivas que legislativas, ${ }^{246}$ fueron las relativas a fijar el gasto público y a establecer las contribuciones, determinando la naturaleza, la cuota, la duración y el modo de percepción. Correspondía también a repartir la contribución directa entre los departamentos del reino y vigilar el empleo de todos los ingresos públicos, haciéndose rendir cuentas. Decretaba la creación o supresión de empleos públicos y determinaba el título, peso y acuñación de moneda, entre otras. Estatuía sobre la administración y ordenaba la enajenación de los dominios nacionales. Otras eran relativas a movimientos de tropas, tanto fuera como dentro del territorio.

Consideración aparte merecen las facultades en materia de relaciones exteriores, pues en este punto la doctrina francesa se ha dividido. Unos autores ven en la colaboración del Ejecutivo y del Legislativo en el terreno de las relaciones exteriores una dero-

246 Ibidem, pp. 75 y 78. 
Este libro forma parte del acervo de la Biblioteca Jurídica Virtual del Instituto de Investigaciones Jurídicas de la UNAM

gación a la regla de la especialización de las funciones; otros perciben en las disposiciones sobre la declaración de guerra un indebida intervención del rey en una materia que es legislativa; los hay quienes conciben las facultades de dirección de las relaciones exteriores como naturalmente ejecutivas y otros más creen que se trata de un terreno sujeto a litigio entre el Legislativo y el Ejecutivo. Para tratar de resolver el problema, Carré de Malberg hizo a un lado la visión que trata globalmente la naturaleza de las relaciones exteriores y se colocó desde el punto de vista de los actos jurídicos que tienen por objeto la política exterior, distinguiendo entre la autorización para ratificar un tratado, dada por el órgano legislativo en forma legislativa y la celebración o ratificación propiamente dicha por el jefe de Estado, que la lleva a cabo, sea por una ley de ratificación, sea por una ley de habilitación, pero en ambos casos el legislador le delega una competencia. Así, los órganos aparecen perfectamente especializados: el órgano legislativo elabora en forma legislativa una ley de autorización o una ley de habilitación y el órgano ejecutivo celebra un tratado. Uno legisla, el otro ejecuta una ley. ${ }^{247}$

Con todo, esta distinción sutil entre ley de autorización o de habilitación y celebración o ratificación no parece haber sido conocida por la Asamblea Constituyente. En efecto, el artículo 3o., del título III, capítulo IV, sección 3ra de la Constitución no hizo alusión alguna a la ley que autorizara o habilitara la celebración. Se refiere simplemente a la ratificación, cuando ordena que "pertenece al cuerpo legislativo ratificar los tratados de paz, alianza y comercio y [que] ningún tratado tendrá efecto más que por esta ratificación". Tampoco el artículo 2o. lo hizo cuando ordenó que "la guerra no puede ser decidida más que por un decreto del cuerpo legislativo, rendido bajo propuesta formal y necesaria del Rey y sancionada por él...”.

En todo caso, en la discusión en el seno de la Asamblea - donde los temas de ambas facultades, la de declarar la guerra y cele-

247 Véase esta polémica interesante en Troper, Michel, La separation des pouvoirs..., cit. pp. 36-38. 
Este libro forma parte del acervo de la Biblioteca Jurídica Virtual del Instituto de Investigaciones Jurídicas de la UNAM

brar tratados se mezclaron, dominando el primero, debido al temor de la Asamblea de que Francia fuera empujada a una guerra aliada con España contra Inglaterra, por un pacto familiar - se impuso la idea que en ambas materias, los dos poderes concurrían puesto que el rey tenía la iniciativa tanto de proponer la guerra como de celebrar un tratado y el cuerpo legislativo podía autorizar o impedir lo propuesto. ${ }^{248}$ Así quedó consagrado en los tres artículos del título III, capítulo IV, sección 3ra.

En efecto, fue por un proyecto de redacción presentado por Mirabeau y bajo la influencia de su discurso que la Asamblea se inclinó por esta solución. Escuchemos a Mirabeau:

¿Hay que delegar al Rey el ejercicio del derecho de hacer la paz y la guerra? ¿Se debe atribuir al cuerpo legislativo? Es así, señores, es con esta alternativa que hasta ahora se ha enunciado la cuestión y confieso que esta manera de plantearla la hace insoluble para mí mismo. No creo que se pueda, sin anular la constitución, delegar al Rey el ejercicio de hacer la paz o la guerra; no creo tampoco que se pueda atribuir exclusivamente este derecho al cuerpo legislativo sin prepararnos a peligros de otra naturaleza y no menos terribles. Pero ¿estamos forzados a hacer una elección exclusiva? ¿no podemos por una de las funciones de gobierno, que contiene a la vez acción y voluntad, ejecución y deliberación hacer concurrir al mismo fin, sino excluir al uno por el otro, a los dos Poderes que constituyen la fuerza de la Nación y que representan su sabiduría?... ${ }^{249}$

La separación de los poderes y su independencia recíproca se expresaban en varias disposiciones. Una, fue el artículo 4o. del título III, capítulo I, sección 3ra que impedía que los ministros y otros agentes del Poder Ejecutivo fueran al mismo tiempo diputados. Esta disposición debe ser leída a la luz de los artículos con-

248 Ibidem, pp. 39 y 40.

249 Mirabeau, "Sur l'exercise du droit de guerre et de paix (20-22 de mayo de 1790)", en Chaussinand-Nogaret, Guy, Mirabeau entre le roy et la Revolution, París, Hachette, 1986, pp. 300 y 301. 
Este libro forma parte del acervo de la Biblioteca Jurídica Virtual del Instituto de Investigaciones Jurídicas de la UNAM

tenidos en el título III, capítulo II, sección 4a. que con objeto de asegurar la independencia recíproca entre los poderes disponía en su artículo 1o. que sólo al rey correspondía el nombramiento y revocación de los ministros. Por otra parte, la responsabilidad de éstos se organizaba a través del refrendo ministerial, el artículo 4o. preveía que "ninguna orden del Rey podía ser ejecutada si no [estaba] firmada y refrendada por el ministro o el ordenador del departamento". Siendo responsables los ministros, según el artículo 5o., "de todos los delitos cometidos por ellos contra la seguridad nacional y la constitución; de todo atentado a la propiedad y a la libertad individual; de toda disipación de los caudales públicos destinados a los gastos de su departamento". Estas disposiciones se complementaron con lo que ordenaba el artículo 1o., del título III, capítulo III, sección 1ra, que autorizaba al cuerpo legislativo a perseguir judicialmente a los ministros, por atentado y complot contra la seguridad del Estado o contra la Constitución.

A este respecto, cabe referirse a los debates que la responsabilidad ministerial suscitó en el seno de la Asamblea Constituyente, a fin de tratar de dilucidar cuál fue el sentido y el alcance de ésta.

El antecedente se remonta al cese que de Necker hiciera el rey, el 13 de julio de 1789. Teniéndole por un ministro liberal que veía con simpatía los cambios, los diputados moderados, entre los que se contaban Mounier, Lally-Tollendal, Target o Barnave, entablaron una serie de intercambios de puntos de vista entre sí y con el rey que ponían en claro la opinión de la Asamblea en el sentido de que a este último correspondía componer su gabinete de la manera como quisiera y que si bien la Asamblea no tenía derecho a solicitar el cese o el nombramiento de ningún ministro, sí contaba con la obligación de expresar la opinión de sus comitentes sobre tal o cuál ministro. 250

En una intervención ante la Asamblea Constituyente, el 6 de noviembre de 1789, Mirabeau propuso los lineamientos de un

250 Troper, Michel, La separation des pouvoirs..., cit., pp.72 у 73. 
Este libro forma parte del acervo de la Biblioteca Jurídica Virtual del Instituto de Investigaciones Jurídicas de la UNAM

régimen parlamentario. $\mathrm{Al}$ denunciar los malentendidos entre la Asamblea y los ministros, propuso una colaboración activa entre el Ejecutivo y el Legislativo. A propósito de los enfrentamientos suscitados en Marsella, expresó lo siguiente: "no hay medio de establecer una fuerza pública seria si el Poder Ejecutivo y la potestad legislativa se miran como enemigos, temiendo discutir en común la cosa pública". Apoyándose en el ejemplo inglés, mostraba cómo la presencia de los ministros en el debate parlamentario aseguraba un control aún más importante que la responsabilidad penal de éstos: "no hay, decía, un miembro de la Asamblea que no pueda interrogar al ministro. Este no puede evitar responder... Cualquier cuestión es oficial, tiene por testigo a toda la Asamblea. Y si el ministro traiciona la verdad, no puede evitar verse perseguir por las palabras de las que se ha servido en su respuesta". Contra la objeción que se hacía, asegurando que la presencia de los ministros significaría una presión sobre los diputados dijo:

¿Se dirá que el ministro tendría más influencia en la Asamblea que si él no tuviera el derecho de asistir a ella?... La influencia de los ministros, cuando no resulta de su talento o de su virtud, se sustenta en maniobras, en seducciones, en concesiones secretas y si algo puede temperar el efecto de esto, es cuando, siendo miembros de la Asamblea, se encuentran sin cesar bajo los ojos de una oposición que no tiene ningún interés en tratarlos con moderación. ${ }^{251}$

El discurso de Mirabeau fue interpretado por la Asamblea como el anuncio de su candidatura para ser ministro. Con alarma se veía que de esa manera al notable influjo que ejercía sobre la Constituyente como tribuno, se agregaría la de su calidad de ministro y la reacción no se hizo esperar: la derecha y la izquierda se coaligaron e impusieron un decreto que prohibía a cualquier miembro de la Asamblea acceder a un ministerio durante toda

251 Citado en Chevallier, Jean-Jacques, op. cit., p. 47. 
Este libro forma parte del acervo de la Biblioteca Jurídica Virtual del Instituto de Investigaciones Jurídicas de la UNAM

la duración de la sesión. ${ }^{252}$ Con ironía amarga, al día siguiente, Mirabeau respondería:

No puedo imaginar que uno de los medios de salud pública de nuestros vecinos no pueda ser entre nosotros más que fuente de males; que no podamos gozar de las mismas ventajas que los Comunes ingleses obtienen de la presencia de sus ministros; que esta presencia no sea entre nosotros más que un instrumento de corrupción o fuente de desconfianza, mientras que permite al Parlamento de Inglaterra conocer a cada instante los planes de la corte, hacer rendir cuentas a los agentes de la autoridad, vigilarlos, instruirlos, comparar los medios con los proyectos y establecer esta marcha uniforme que remueve todos los obstáculos. ${ }^{253}$

Más tarde, el 7 de marzo de 1791, a nombre de la Comisión redactora de la Constitución, Démunier propuso un proyecto que presentaba notable similitud al anterior sentir de la Asamblea, pues reservaba al rey el nombramiento y el cese de sus ministros, pero confería a la Asamblea el derecho de presentar un memorial sobre su conducta, pudiendo declarar que había perdido la confianza de la nación. Si bien este memorial no tenía más valor que el de expresar el deseo de la Asamblea, no obligaba al rey de ninguna forma. Por lo contrario, una acusación contra un ministro acarreaba su revocación. Finalmente, cuando se llevó a cabo la redacción definitiva de la Constitución, la comisión no creyó conveniente mantener una facultad para la Asamblea que no producía efecto alguno y retiró el supuesto derecho de hacer tal declaración. Así, puede concluirse que no existió en el ánimo de los diputados constituyentes, a pesar de los esfuerzos de Mirabeau, la idea de conceder al cuerpo legislativo la facultad de cesar en sus funciones a un ministro, pues no imaginó que los

252 Chaussinand-Nogaret, Guy, op. cit., p. 296.

253 Mirabeau, "Sur l'interdiction faite aux députés de devenir ministres (7 de noviembre de 1789)", en Chaussinand-Nogaret, Guy, Mirabeau entre le roy et la Revolution, p. 297. 
Este libro forma parte del acervo de la Biblioteca Jurídica Virtual del Instituto de Investigaciones Jurídicas de la UNAM

ministros pudieran ser sometidos a una responsabilidad política previa declaración de la Asamblea. ${ }^{254}$

Ahora bien, según Troper, el hecho que la Constitución no dispusiera con la posibilidad de la Asamblea de deponer a un ministro, por razones puramente políticas no quería decir de manera mecánica que éstos fueran independientes respecto de aquélla en el ejercicio de sus funciones como lo ha sostenido la doctrina clásica. Añade que para que esta afirmación se sostuviera, habría sido necesario se llenaran tres condiciones: que las infracciones fueran limitativamente enumeradas y definidas por un texto formal que la Asamblea no pudiera modificar; que el órgano al que correspondía pronunciarse sobre la calificación jurídica de los hechos materiales imputados a los ministros no fuera la Asamblea misma y fuera independiente de ella; y, en fin, que la desobediencia a las órdenes de la Asamblea no fuera constitutiva de infracción. Y añade que ni en los debates de la Asamblea Constituyente, ni en la práctica de la Asamblea Legislativa se cumplieron esas condiciones y que la responsabilidad penal, tal como quedó plasmada en la Constitución de 1791, permitió someter a los ministros a una dependencia estrecha frente al cuerpo legislativo. ${ }^{255}$

En lo que concierne a las competencias propiamente legislativas, la Asamblea fue dotada de la iniciativa de leyes y el rey sólo tenía la posibilidad de invitarla a tomar en consideración un tema. Antes de ser votado un proyecto de ley era sometido a tres lecturas con ocho días de intervalo. Después de la primera, el proyecto se imprimía y distribuía, y la votación se debía llevar a efecto con un quórum de al menos doscientos diputados presentes y por mayoría absoluta de votos, aunque una declaración de urgencia podía dispensar todas estas formalidades, según lo estipulaban los artículos del 1o. al 11 del título III, capítulo III, sección 2a. Una vez aprobado un texto por la Asamblea, no era

254 Troper, Michel, La separation des pouvoirs..., cit., pp. 74 y 75.

255 Ibidem, pp. 75-78. 
Este libro forma parte del acervo de la Biblioteca Jurídica Virtual del Instituto de Investigaciones Jurídicas de la UNAM

más que un decreto, pero necesitaba de la sanción real para convertirse en ley. Como ha sido señalado, el rey participaba en la función legislativa, por medio del veto suspensivo, lo que significaba que este veto era superable si el mismo texto era aprobado por tres legislaturas consecutivas, así, convirtiéndose en ley ejecutoria, según los artículos del 1o. al 6o. del título III, capítulo III, sección 3ra.

En diversos artículos del título III, capítulo IV, la Constitución regulaba el ejercicio del Poder Ejecutivo. La titularidad unipersonal de éste se ordenaba en su artículo 1o.: "el Poder Ejecutivo supremo reside exclusivamente en la mano del Rey. El Rey es el jefe supremo de la administración general del reino: el cuidado de vigilar el mantenimiento del orden y de la tranquilidad pública le está confiado. El Rey es el jefe supremo de la armada de tierra y de la armada naval. Al Rey le es delegado el cuidado de vigilar la seguridad exterior del reino y de mantener los derechos y las posesiones de éste". Consecuente con su carácter de jefe supremo de la administración general, los artículos 2o., 3o. y 4o. del mismo título y capítulo le dan esencialmente facultades de nombramiento, como clave para ejercer esas funciones de carácter administrativo.

Para el ejercicio de estas facultades, el rey se hacía aconsejar y ayudar por los ministros, que eran nombrados y revocados por él y, dado que no se preveía atisbo alguno de sistema parlamentario, sólo dependían de éste y no podían ser escogidos de entre los diputados de la Asamblea, ni de entre los miembros del tribunal de casación, ni de entre los altos jurados.

El carácter no parlamentario del régimen establecido por la Constitución hacía que los ministros trabajaran aisladamente, no eran solidarios entre sí, ni había consejo de ministros, ni presidente del mismo. En fin, que mayoritariamente la Asamblea Constituyente consideraba a los ministros únicamente como los agentes del Poder Ejecutivo y no como los "intermediarios" naturales y necesarios entre el poder real, de una parte y el poder parlamentario de la otra. Y, en consecuencia, lo más que se pudo 
Este libro forma parte del acervo de la Biblioteca Jurídica Virtual del Instituto de Investigaciones Jurídicas de la UNAM

atemperar en la separación rígida de los poderes, consistió en que los ministros tuvieran acceso a la Asamblea Legislativa y la posibilidad de tomar la palabra, bajo ciertas condiciones: debían presentar a la apertura de la sesión un compendio de los gastos a efectuar en sus departamentos, debían rendir cuentas del empleo de las sumas que estaban destinadas para ello y debían indicar los abusos que hubieran podido introducirse en las diferentes partes del gobierno. Podrían ser escuchados cada vez que les fuera solicitado sobre temas relativos a su administración o para ofrecer aclaraciones, también en temas ajenos, cuando así lo acordara la Asamblea según lo señalaban los artículos 7o. del capítulo II, secciones 4a. y 10a. del capítulo III, sección 4a., ambos del título III.

Uno de los temas que más vivamente interesó a la Constituyente desde sus primeras sesiones fue el de la nueva organización judicial. No debe sorprender el que haya sido así, si se considera que entre sus miembros había una gran mayoría de hombres relacionados con la justicia, pues ese cuerpo colegiado se integraba de abogados, notarios, procuradores, consejeros de los Parlamentos, magistrados de jurisdicciones inferiores, etcétera. El tema se mostraba complicado en más de un aspecto, ya que si todos estaban de acuerdo en modificar profundamente la justicia criminal, no todos lo estaban sobre el procedimiento civil. Había además una cuestión política: era palpable un sentimiento extendido de desconfianza hacia los parlamentos, que durante la convocatoria a los Estados Generales se habían mostrado ser firmes defensores de los antiguos usos. En consecuencia, se pretendía no sólo suprimirlos, sino evitar que en adelante ninguna corte de justicia pudiera comportarse como los parlamentos. Invocando la separación de poderes se acotaban no sólo facultades del rey en la materia, sino que se deseaba disminuir los de las gentes de justicia para constreñirles a no ocuparse sino de lo concerniente a la justicia misma. ${ }^{256}$

Dadas las dificultades y la complejidad del asunto, se decidió proceder paulatinamente, a través de reformas parciales de aque-

256 Godechot, Jacques, Les institutions..., cit., pp. 113 y 114. 
Este libro forma parte del acervo de la Biblioteca Jurídica Virtual del Instituto de Investigaciones Jurídicas de la UNAM

llos aspectos en donde se constataban los abusos más palpables. Además de una serie de medidas tendientes a aumentar las garantías del acusado, se tomaron otras que temperaban las penas y evitaban que éstas recayeran también sobre la familia de los condenados, o que se confiscaran sus bienes.

El 24 de marzo de 1790, la Asamblea decidió proceder a llevar a cabo una profunda transformación del sistema judicial. En nombre de la comisión redactora de la Constitución, Thouret abrió el debate con un discurso importante que sentó las bases de la reforma. "El Poder Judicial [afirmó] es aquél de los Poderes Públicos cuyo ejercicio habitual tendrá la mayor influencia sobre la felicidad de los particulares, sobre el progreso del espíritu público, sobre el mantenimiento del orden público y sobre la estabilidad de la constitución". ${ }^{257}$

A continuación, señaló con acierto los graves problemas graves que enfrentaba la justicia en Francia:

El más bizarro y mas pernicioso de todos los abusos que han corrompido el ejercicio del Poder Judicial era que las corporaciones y los simples particulares poseyesen patrimonialmente, como se decía, el derecho de hacer administrar la justicia en su nombre, que otros particulares pudiesen adquirir a título de herencia o de compra, el derecho de juzgar a sus conciudadanos y que los justiciables estuvieran obligados a pagar a los jueces para obtener un acto de justicia. La comisión os propone, por medio de los cinco primeros artículos del título I de su proyecto, consagrar, como máximas inalterables, que la justicia no pueda ser aplicada más que en nombre del Rey, que los jueces deban ser electos por los justiciables e instituidos por el Rey, que ningún oficio de judicatura pueda ser venal y que la justicia sea aplicada gratuitamente. El segundo abuso que ha desnaturalizado al Poder Judicial en Francia es la confusión establecida en las manos de sus depositarios, funciones que le son propias, con las funciones incompatibles e incomunicables de los otros Poderes Públicos. Émulo de la

257 Thouret, "Discurso del 24 de marzo de 1790", en Furet, François y Halévi, Ran, La Monarchie..., cit., p. 472. 
Este libro forma parte del acervo de la Biblioteca Jurídica Virtual del Instituto de Investigaciones Jurídicas de la UNAM

potestad legislativa, revisa, modifica o rechaza las leyes; rival del Poder administrativo, entraba las operaciones del mismo, detiene el movimiento de éste e inquieta a sus agentes... digamos que una Nación que ejerce la potestad legislativa por medio de un cuerpo permanente de representantes no puede dejar a los tribunales, ejecutores de sus leyes y sometidos a su autoridad, la facultad de revisar esas leyes. Digamos en fin que, cuando esta Nación elige a sus administradores, los ministros de la justicia distributiva no se deben mezclar con la administración cuyo cuidado no les ha sido confiado... Había tribunales privilegiados, para ciertas clases de litigantes privilegiados. Se distinguía en materia criminal un delito privilegiado de un delito común...258

\section{Para remediar dichos vicios planteó lo siguiente:}

Lo que la comisión os ha propuesto entraña la destrucción necesaria de todos los tribunales existentes, para reemplazarlos por una creación de establecimientos nuevos... Una buena administración de la justicia parece ligada principalmente a las tres condiciones siguientes: 1) Que los tribunales no sean más numerosos que lo que exige la necesidad real del servicio; 2) que sean, no obstante, suficientemente cercanos de los justiciables para que el gasto y la incomodidad de los desplazamientos no prive a ningún ciudadano del derecho de hacerse aplicar la justicia; 3) que fuera de los casos en que la facultad de apelación es por lo limitado del objeto, más una agravación que un recurso, haya dos grados de jurisdicción, pero nunca más de dos... La comisión os propone un juez de paz por cantón y un solo tribunal real por distrito. ${ }^{259}$

A continuación, describió sumariamente tanto a los juzgados de paz como a los juzgados de distrito:

La competencia de esos jueces [los de paz] debe estar limitada a las cuestiones de convención muy simple y del valor más pequeño, y a las cuestiones de hecho que no puedan ser bien juzgadas más

258 Ibidem, pp. 473 y 474.

259 Ibidem, pp. 475 y 477. 
Este libro forma parte del acervo de la Biblioteca Jurídica Virtual del Instituto de Investigaciones Jurídicas de la UNAM

que por el hombre de campo, que verifica sobre el lugar mismo el objeto del litigio y que encuentra, en su experiencia, reglas de decisión más seguras que los que la ciencia de las formas y de las leyes pueda proporcionar a los tribunales sobre esas materias... Hay que separar las funciones de los jueces de paz del engorro de las formas y la intervención de los practicantes: porque la principal utilidad de esta institución no se llenará si ella no procura una justicia muy simple, muy expeditiva, exenta de gastos y cuya equidad natural dirija su marcha, antes bien que los reglamentos puntillosos del arte de juzgar... La competencia del tribunal real de distrito comienza o acaba la de los jueces de paz; completa al sistema de la primera instancia de jurisprudencia en el orden ordinario... Un solo tribunal debe bastar en cada distrito, sea que se considere la medida común del territorio sobre la cual los distritos han debido estar distribuidos, sea que se vincule a la tasa común de la población que deba contener...260

Para la concreción de la reforma se discutieron de entre una multitud de proyectos, tres principalmente, el de Thouret, el de Duport y el de Sieyès. Se consideró a este último demasiado complicado y se trató de combinar los elementos de los otros dos.

Como muchos de sus contemporáneos, Sieyès se ocupó de la administración de justicia. Su reflexión principal se había centrado en la justicia penal, teniendo como fuente de inspiración a Beccaria, aunque también había redactado algunas ideas sobre la administración de justicia civil. Para marzo de 1790 publicó un proyecto ya redactado en el mes de septiembre anterior y que había decidido no sacar a la luz por las diferencias y los roces habidos con la comisión redactora de la Constitución. El texto constaba de ciento setenta y seis artículos y las bases sobre las que se sustentaba eran las siguientes: la justicia se aplicaba en nombre del rey y se organizaba sobre dos instancias o grados de jurisdicción; se preveía la existencia de jurados tanto en lo penal como en lo civil, compuestos por jueces electos. Es sobre este último punto que el desacuerdo con la comisión se producía, ya que

260 Ibidem, pp. 477-479. 
Este libro forma parte del acervo de la Biblioteca Jurídica Virtual del Instituto de Investigaciones Jurídicas de la UNAM

Sieyès atribuía a sus jurados un carácter peculiar, al concebirlos integrados esencialmente por gente versada en leyes y pudiendo pronunciarse tanto en derecho como sobre los hechos. ${ }^{261}$

Ambos proyectos proponían la institución de los jurados, pero Thouret la reservaba sólo para los procesos criminales. Aunque abundaban los que deseaban su extensión a la justicia civil se circunscribió sólo a aquéllos, ante el argumento plausible de la enorme dificultad para distinguir entre el hecho y el derecho en materia civil.

El carácter ambulatorio de los jueces propuesto por Duport fue objeto de discusión. Había quien veía en ello la ventaja de la imposibilidad de la reconstitución de la magistratura del ancien régime y quien lo objetaba porque le disminuía majestad a la justicia.

De igual forma, les dividía el tema del establecimiento de tribunales de apelación: se temía que con ellos fuera a resucitarse a los parlamentos; bajo propuesta de Pétion, se decidió que servirían de tribunal de apelación los tribunales más cercanos al tribunal de distrito en cuestión.

Existía un descrédito generalizado del oficio de juez, a causa de la venalidad de los cargos y de los excesos de los parlamentos, por lo que la inmensa mayoría era hostil a la institución de jueces profesionales y se prefería a los jueces de paz. No obstante, se deseaba exigir ciertos conocimientos jurídicos a los jueces de distrito, por lo que se decidió que fueran escogidos de entre personas con cinco años, al menos, de ejercicio. El rey no estaría representado en el tribunal sino por un comisario, nombrado por él y encargado de aplicar la ley, pero el titular de la acción penal o acusador público sería electo como los jueces. ${ }^{262}$

La obra de la Constituyente en materia judicial se forjó en diversas leyes como la del 16 al 24 de agosto de 1790, la del 16 de septiembre de 1791 o el Código Penal del 23 de septiembre de 1791. Algunas de las disposiciones más importantes de la pri-

261 Bastid, Paul, Sieyès..., cit., p. 96.

262 Godechot, Jacques, Les institutions..., cit., pp. 115 y 116. 
Este libro forma parte del acervo de la Biblioteca Jurídica Virtual del Instituto de Investigaciones Jurídicas de la UNAM

mera ley pasaron al capítulo V, título III de la Constitución, dedicado al Poder Judicial.

En efecto, el año de 1790 fue de gran importancia para la reorganización de la justicia en Francia: el 16 de marzo la Asamblea Nacional suprimió las reales órdenes de aprehensión [lettres de cachet]. El 30 de abril se instituyó "el Jury". El 5 de mayo la Asamblea Nacional decretó la elección de los jueces. El 16 de Agosto decretó la creación de las justicias de paz y la desaparición de los tribunales señoriales. El 21 de agosto decretó la creación de los tribunales militares. El 6 de septiembre suprimió oficialmente los parlamentos y las otras cortes de justicia del antiguo régimen. El 27 de noviembre emitió la ley nacional que organizó el Tribunal de Casación, cuya función se limitaba a enmendar los vicios de forma. El 15 de diciembre suprimió la venalidad y la transmisión hereditaria de los oficios. ${ }^{263}$

Amén de una serie de artículos dedicados a las garantías que deberían ser observadas en beneficio de las personas que eran objeto de arresto, de inculpación y proceso o de prisión, algunos de los artículos de este capítulo enfatizaban la separación de poderes, al señalar que el Poder Judicial no podría ser ejercido en ningún caso por el cuerpo legislativo o por el rey y, como contrapartida, los tribunales no podrían inmiscuirse en el ejercicio del Poder Legislativo, suspender la ejecución de las leyes, ni emprender funciones administrativas o citar a comparecer a los administradores en razón de sus funciones, tal como lo disponían los artículos 1o. y 3o. del mencionado capítulo V, título III.

$\mathrm{Al}$ garantizarse el derecho de los ciudadanos de solucionar sus diferendos por la vía arbitral, según el artículo 5o.; al establecerse, de acuerdo al artículo 2o., que la justicia sería gratuita, impartida por jueces electos temporalmente por el pueblo y al instituirse la existencia de uno o varios jueces de paz en los cantones y en las ciudades, según el artículo 7o., se distinguía implícitamente entre árbitros, jueces ordinarios y jueces de paz. Los

263 Tulard, Jean et al., Histoire et dictionnaire de la Revolution francaise. 1789-1799, París, Laffont, 1998, pp. 321-330. 
Este libro forma parte del acervo de la Biblioteca Jurídica Virtual del Instituto de Investigaciones Jurídicas de la UNAM

árbitros podrían ser nombrados en cualquier materia y escogidos de entre no importa que grupo de ciudadanos. Por su parte, la institución de los jueces de paz era inspiración más de Holanda que de Inglaterra, pues Voltaire les había hecho célebres como "hacedores de paz"; estos jueces recibían un bajo estipendio por funciones que cumplían más como ciudadanos que como jueces; se les elegía por dos años, sin exigírseles ninguna competencia jurídica. Los jueces de los tribunales de distrito eran electos, pero por seis años y ellos sí obligatoriamente de entre jueces u hombres de ley con previo ejercicio de al menos cinco años y recibían un salario del Estado. ${ }^{264}$

La necesidad de crear una jurisdicción suprema era una demanda largamente compartida entre los miembros de la Constituyente, no obstante el peligro de ver restaurarse una especie de Parlamento. Para evitar sus inconvenientes, fueron presentados diversos proyectos, desde los que proponían seccionarla, hasta los que deseaban fuera ambulante, pasando por quien, como Thouret, preveía una sala en París y seis más en diferentes centros provinciales. Esta propuesta suscitó la objeción comprensible de que engendraría la dispersión de las salas. Así que ganó terreno la idea de una sola sala con sede en París, pero con atribuciones estrictamente acotadas.

En consecuencia, el artículo 19 del mismo capítulo y título estableció un único Tribunal de Casación para todo el reino, nombrado por el cuerpo legislativo, teniendo como funciones: pronunciarse sobre las solicitudes de casación o anulación contra sentencias pronunciadas en última instancia por los tribunales; sobre solicitudes en reenvío de un tribunal a otro a causa de sospecha legítima; sobre las liquidaciones de jueces y las acciones judiciales contra un tribunal entero. De acuerdo al artículo 20, su misión era anular los procedimientos en los que las formas hubieran sido violadas o que contuvieran una contravención al texto de la ley, pero no se le concedía la menor facultad para in-

264 Ibidem, pp. 117 y 118. 
Este libro forma parte del acervo de la Biblioteca Jurídica Virtual del Instituto de Investigaciones Jurídicas de la UNAM

terpretar a la ley, al prohibírsele terminantemente conocer del fondo del negocio.

Otra tarea del Tribunal de Casación era la de lograr la unidad de la jurisprudencia en todo el reino, lo que motivaba al artículo 21 a disponer que cuando después de dos casaciones, la sentencia del tercer tribunal fuera atacada por los mismos medios que las dos primeras, la cuestión no podía ser solventada ante el Tribunal de Casación, sin haber sido sometida al cuerpo legislativo, que pronunciaría un decreto declaratorio de la ley con el cual el Tribunal de Casación estaría obligado a conformarse. Y por su parte, el artículo 22 disponía que cada año el Tribunal estaría obligado a enviar ante el cuerpo legislativo una delegación de ocho de sus miembros que presentaría el estado de las sentencias pronunciadas, al lado de cada una de las cuales estaría la información abreviada del negocio y el texto de la ley que hubiera determinado la decisión.

Finalmente, el artículo 23 del mismo capítulo V preveía el funcionamiento de una Alta Corte de Justicia Nacional, integrada por los miembros del Tribunal de Casación y de los altos jurados. Esta Corte debía conocer de los delitos cometidos por ministros y agentes principales del Poder Ejecutivo y de los crímenes cometidos que atacaran la seguridad general del Estado, cuando el cuerpo legislativo hubiera decretado la acusación. Esta Corte no debía reunirse más que por petición del cuerpo legislativo.

Como conclusión, Godechot señala que la organización judicial francesa llevada a cabo por la Constituyente fue, sin duda, una de las partes más logradas de su obra: el sistema aparece como lógico y coherente, al que sólo le faltó el Código Civil y el de Procedimientos Civiles; la justicia se acercó singularmente a los justiciables y, aunque no se logró la gratuidad planteada, los costos fueron considerablemente disminuidos; las penas fueron atemperadas y la justicia criminal humanizada. ${ }^{265}$

265 Ibidem, p. 119. 
Este libro forma parte del acervo de la Biblioteca Jurídica Virtual del Instituto de Investigaciones Jurídicas de la UNAM

Aquí vale la pena consignar la opinión valiosa del célebre profesor de la Facultad de Derecho de Estrasburgo, Carré de Malberg, sobre el significado profundo de la obra de la Constituyente de 1789 a 1791 en lo que concierne a la administración de justicia, porque creo que tiene valor aclaratorio.

Carré de Malberg nos recuerda que aunque la Revolución parecía haber consagrado la distinción de los tres poderes, en realidad trató como madrastra a la autoridad judicial y la colocó en una condición de inferioridad, de la cual los jueces no fueron más que muy imperfectamente liberados por el artículo 4o. del Código Civil. El solo hecho - añadía - de que según la ley del 27 de noviembre al 1 de diciembre de 1790, el Tribunal de Casación estuviera caracterizado, y debiera funcionar, como un satélite y un auxiliar de la Asamblea Legislativa, bastaba para excluir la idea que el cuerpo judicial, concebido como servidor de la legislatura, pudiera en alguna medida o bajo algún punto de vista ser admitido a comportarse como eventual censor de leyes, respecto de las cuales únicamente se ocupaba de asegurar la aplicación. ${ }^{266}$

Asimismo, Carré de Malberg expresó que esta especie de inmunidad de la que se beneficiaba la ley y que tenía como efecto colocarla por encima de cualquier discusión, substrayéndola a toda intervención de un control judicial, tenía además otra causa, ésta mucho más grave que la anterior; la cual debía relacionarse ante todo con la concepción que hicieron prevalecer los creadores revolucionarios del derecho público francés tocante a la cualidad con la que el cuerpo legislativo ejercía sus facultades legislativas. A este respecto, este autor distingue dos concepciones:

La primera concebiría al Poder Legislativo como un poder de distinta naturaleza al del poder constituyente. En esta primera visión, el cuerpo legislativo no podría ser confundido con el pueblo soberano: no sería sino una simple autoridad que estaría investida no de la soberanía, sino solamente cumpliría una fun-

266 Carré de Malberg, Raymond, "La sanction jurisdictionnelle des principes constitutionnels", Annuaire de l'Institut International de Droit Public, París, 1929, p. 146. 
Este libro forma parte del acervo de la Biblioteca Jurídica Virtual del Instituto de Investigaciones Jurídicas de la UNAM

ción de potestad y que en el ejercicio de esta función actuaría al mismo título secundario que los otros cuerpos o personajes constituidos, en el ejercicio de sus funciones respectivas. Las leyes que emitiría no serían, en relación a la Constitución sino actos de potestad subalterna, cuya legitimidad no se obtendría más que en tanto que su contenido, obra de un órgano constituido, no entrara en contradicción con ninguna de las prescripciones superiores planteadas por el soberano mismo. Se entiende que en esas condiciones los jueces - aunque sometidos a las leyes ordinarias en el sentido que su función consistía principalmente en aplicarlas - no deberían ni podrían aplicarlas, sino después de haberse asegurado de su regularidad constitucional, ya que ante la Constitución se encontraban, por el ejercicio de su función, en una posición de igualdad con la legislatura. ${ }^{267}$

La segunda concepción a que se refiere Carré de Malberg es el sistema francés de organización de los poderes constituidos que, según él, desde sus inicios tomó una orientación harto diferente. Abstracción realizada de la decisión excepcional por la que el rey estaba considerado como "representante" para algunas situaciones especiales, la Constitución de 1791, a continuación de la Declaración de los Derechos del Hombre de 1789 estableció, entre el cuerpo legislativo y las otras autoridades, una especie de desigualdad que provenía de una causa profunda que excluía toda posibilidad de una separación verdadera y fundamental entre el Poder Legislativo y el Poder Constituyente.

En efecto, en tanto que el Ejecutivo y la autoridad judicial no ejercían las atribuciones comprendidas en su competencia, sino en la calidad o con los poderes de funcionarios operando al servicio de la Nación, la Asamblea de los diputados, concebida como el órgano que "quería por la Nación" se convertía en "la representación” misma de ésta y adquiría por esta razón la posesión de la soberanía nacional con las atribuciones que a ella se vinculaban.

267 Ibidem, pp. 146 y 147. 
Este libro forma parte del acervo de la Biblioteca Jurídica Virtual del Instituto de Investigaciones Jurídicas de la UNAM

Esto es lo que la declaración de 1789 formulaba en términos sorprendentes, cuando en su artículo 6o. decía de la ley emanada de las decisiones de la legislatura, que ella era la expresión de "la voluntad general" y la continuación del texto precisaba y forzaba el alcance de esta definición, especificando que "por sus representantes, todos los ciudadanos" ejercían "el derecho de concurrir a su formación". Es decir, que el pueblo mismo o la totalidad de los ciudadanos se encontraban presentes, en el momento de la confección de las leyes, en el cuerpo legislativo.

Este autor señala que un abismo jurídico se encontraba abierto entre el Poder Legislativo de la Asamblea de los Diputados, que era representativa de la Nación, y las competencias de las otras autoridades, que no cumplían sino oficios de funcionario. Se comprende así — dice - que la Constitución de 1791 (título III, capítulo II, sección 1 ra, artículo 3o.) haya podido concluir de estas premisas que "no había en Francia autoridad superior a la de la ley". ${ }^{268}$

Para nuestro autor, desde el momento en que los constituyentes de 1789 a 1791 partieron de la idea que era la Nación misma, compuesta de la totalidad de sus ciudadanos, la que por medio de la Asamblea Nacional legislaba, se encaminaban en una vía que debía lógicamente conducirlos a descartar cualquier posibilidad de discusión y de recurso tendiente a invalidar las leyes, así fuera por causas de inconstitucionalidad. De la idea que trataba al cuerpo legislativo como la encarnación del soberano resultaba que la Asamblea Legislativa, de una parte y, de otra, las autoridades ejecutivas o judiciales no ejercían la potestad del Estado en grados desiguales solamente, sino que, aunque estaban investidas de potestades de naturaleza diferente, a ninguna de las autoridades de esta segunda clase podía, en consecuencia, tolerársele que pudiera emitir un juicio sobre la obra soberana del legislador. En suma, con el punto de partida adoptado por la Revolución, en cuanto a la calidad con la cual la Asamblea de los Diputados

268 Ibidem, pp. 148 y 149. 
Este libro forma parte del acervo de la Biblioteca Jurídica Virtual del Instituto de Investigaciones Jurídicas de la UNAM

ejercía las facultades legislativas, la diferencia efectiva entre leyes constitucionales y leyes ordinarias se encontraba en entredicho. ${ }^{269}$

Aseguraba Carré que a pesar de algunos esfuerzos, esta Constitución no organizaba ningún medio jurídico que permitiera examinar la validez de las leyes sospechosas de haber violado las disposiciones de aquélla. En su título I afirmaba que el Poder Legislativo no podría hacer ninguna ley que vulnerara el ejercicio de los derechos naturales garantizados por la Constitución. Sin embargo, como esta afirmación no estaba acompañada de ninguna sanción positiva, se podría decir que además de haber erigido a la Asamblea Nacional en soberano efectivo, la constitución de 1791 le depositaba su confianza - según la expresión de Jèze y de Hauriou - y se remitía a su apreciación en cuanto al punto de saber lo que era lícito de hacer por sus leyes. Esta condición se corroboraba por la continuación del título 1 que reservaba a la ley el poder de imponer a las libertades constitucionales todas las condiciones de ejercicio o limitaciones que parecieran necesarias en el interés de la seguridad pública para la preservación de los derechos de terceros: lo que equivalía prácticamente a dar carta blanca al cuerpo legislativo para la reglamentación de esas libertades. ${ }^{270}$

Por haberse adoptado la idea de que la obra de la legislatura era la del pueblo mismo, la Revolución, según Carré de Malberg, se encaminó en dirección diametralmente opuesta a la de las instituciones que permitían poner en entredicho la validez de las leyes. Señalar una ley de inconstitucional era, en efecto, atacar todo o parte de sus disposiciones, pretendiendo que el legislador no tenía la facultad de emitirlas, porque contradirían una prescripción constitucional. En otros términos, la cuestión de constitucionalidad de una ley se remitía esencialmente a una cuestión de interpretación de los textos y los principios constitucionales: interpretación que tenía por objeto preciso investigar y fijar la extensión, y el alcance de las restricciones aportadas por

269 Ibidem, pp. 150 y 151.
270 Ibidem, pp. 151 y 152. 
Este libro forma parte del acervo de la Biblioteca Jurídica Virtual del Instituto de Investigaciones Jurídicas de la UNAM

la Constitución a la potestad del legislador, ¿quién estaría, entonces, más calificado para esa interpretación que aquel que había sido el autor mismo de la Constitución, a saber, el pueblo? ¿Ejus est interpretari, cujus est condere?

Ahora bien, según la doctrina revolucionaria, el pueblo no estaba menos presente en la confección de las leyes, por medio de la legislatura, que en la fundación de la Constitución, por medio de la constituyente. Desde ese momento, la legislatura se encontraba lógica y naturalmente llamada - y eso en el momento mismo de la elaboración de las leyes - a solucionar, en virtud de su poder de representación popular, las dificultades que pudiera suscitar la adopción de tal o cual disposición legislativa, cuya conformidad con la Constitución fuera dudosa o controvertida. Por medio del órgano de la legislatura, el pueblo mismo fijaría, de manera definitiva, el alcance de las voluntades iniciales que él había enunciado en el acta constitucional. En una palabra, era al cuerpo legislativo que pertenecía examinar y decidir, en ocasión y en el curso de sus deliberaciones sobre un proyecto de ley, si el contenido de ese proyecto era o no conciliable con la Constitución; es decir, si podía ser adoptado por la vía simplemente legislativa o, si al contrario, para su adopción necesitaba recurrirse al procedimiento especial exigido por las modificaciones a la ley constitucional. De esta forma regresamos una vez más - concluye Carré de Malberg - a la supremacía parlamentaria. ${ }^{271}$

Este tema está vinculado con el de la garantía de los derechos que, al decir de Fioravanti, constituye el "punto débil" y más problemático de la Revolución francesa. Todas las garantías ofrecidas por la Declaración de Derechos de 1789, en efecto, convergen en un único punto: "sobre la supremacía en materia de derechos y libertades, de la ley general y abstracta". En la mencionada Declaración y en general en la Revolución todo remitía a la ley y a la autoridad del legislador. Como ya se dijo, la ley general y abstracta sería el instrumento más idóneo para la garantía de los derechos. Se sería libre porque se estaba gobernado de manera

271 Ibidem, pp. 154 y 155. 
Este libro forma parte del acervo de la Biblioteca Jurídica Virtual del Instituto de Investigaciones Jurídicas de la UNAM

"no arbitraria", porque en materia de derechos y libertades no valía ya la voluntad de un hombre contra la de otro, porque habían sido abolidas las dominaciones de carácter personal, porque sólo la ley podía disponer de nosotros mismos. Pero, aquí se abría el problema, ¿cómo defenderse contra la hipótesis de que precisamente el legislador fuera el peor enemigo de los derechos y de las libertades? Es más, ¿en qué medida los constituyentes franceses se plantearon este problema? La respuesta de la Revolución fue tremendamente simple: el legislador "no puede lesionar" los derechos individuales porque es "necesariamente justo" y es tal, porque encarna en sí la voluntad general del pueblo o Nación. Se explica así que la Declaración agote el sistema de garantías en el envío obligado a la ley. El objetivo de la Revolución era construir un legislador virtuoso, necesariamente respetuoso de los derechos de los individuos, en cuanto expresión necesaria de la voluntad general. ${ }^{272}$

En suma, toda esta descripción extensa ha querido poner en evidencia la enorme dificultad que entrañaba el diseñar instituciones, la búsqueda de un gobierno que fuera eficaz y que al mismo tiempo no fuera despótico, los obstáculos para construir un edificio constitucional que asegurara los derechos de los gobernados sin debilitar a los gobernantes, de tal suerte que les impidiera cumplir con sus tareas esenciales. En efecto, parecía extremadamente difícil lograr un equilibrio tal entre los poderes que impidiera que uno prevaleciera sobre el otro, de manera que la libertad fuera preservada. No obstante, aún en la hipótesis de que un poder pudiera detener al otro, no era fácil sortear la parálisis de la maquinaria estatal, lo que a su vez conduciría a la anarquía y, consecuentemente, a una salida de fuerza.

El artículo 16 que contiene el dogma de la separación de los poderes fue aprobado sin debate prácticamente por unanimidad. El principio fue adoptado aún antes de saberse qué forma tendría la Constitución, porque nadie podía oponerse a lo que no era sino el rechazo al despotismo o, aún más, a lo que era una

272 Fioravanti, Maurizio, Los derechos fundamentales..., cit., pp. 69-74. 
Este libro forma parte del acervo de la Biblioteca Jurídica Virtual del Instituto de Investigaciones Jurídicas de la UNAM

simple definición de Constitución, pues, cualquier Constitución no era concebida sino como el conjunto y separación de poderes. Si la separación de poderes hubiera implicado un sistema en el que los órganos hubieran estado especializados y jerarquizados, se hubieran dividido las opiniones en el seno de la Asamblea Nacional. Entonces, se trataba de un principio puramente negativo que significaba que un órgano no debía acumular todas las facultades y que se justificaba fácilmente, ya que el cúmulo de facultades concentradas en un órgano haría de su titular un déspota que gobernaría caprichosamente. Al contrario, si las competencias eran repartidas entre varios y el que ejecutara la ley no tuviera el poder de hacerla o modificarla al realizar su aplicación, no podría actuar sino en virtud de una ley anterior. Así, los gobernados al obedecer no obedecían a un hombre, sino a la ley.

Con Carré de Malberg, se puede decir que el equilibrio entre autoridades especializadas se podía lograr si las funciones fueran equivalentes, pero no era así porque no se podía pretender que la función de hacer leyes pudiera ser equivalente a la que consistía en ejecutarlas. Por otra parte, si las funciones estaban jerarquizadas y los órganos especializados, el que ejercía la función más elevada era naturalmente superior a los otros y no parecía lógico que un poder subordinado pudiera detener a otro superior.

Como se pudo ver, la ambigüedad de mantener dos fuentes de legitimidad, o dos soberanías: la monárquica y la de la nación, y de pretender hacerlas coexistir en equilibrio, como lo habían logrado los ingleses, sólo se pudo sostener fugazmente. Pronto la equivalencia y el equilibrio fueron desechados, para ser substituidos por la subordinación del Ejecutivo al Legislativo, en tanto que representante de la nación.

La separación de poderes establecida por la Asamblea Nacional en la Constitución de 1791 no implicó su especialización, ya que a la separación rígida puesta en pie se le pusieron una serie de excepciones tales que la negaron. Aunque el veto del rey fuera meramente suspensivo, realmente le hacía participar en la función legislativa. Las relaciones internacionales eran condu- 
Este libro forma parte del acervo de la Biblioteca Jurídica Virtual del Instituto de Investigaciones Jurídicas de la UNAM

cidas compartidamente tanto por el rey como por la Asamblea Nacional, en colaboración. El cuerpo legislativo participaba en la función jurisdiccional, por la facultad de encausar a los ministros. Por otra parte, la regla de la independencia recíproca de los poderes sufría aquí un quebranto, pues, aunque los ministros eran sólo penalmente responsables, lo eran por faltas no definidas con precisión, o no perfectamente tipificadas, de manera que el cuerpo legislativo les podía encausar por no importaba cuál de sus conductas. Por una concepción que arrancaba con Montesquieu, pasaba por la Asamblea Constituyente y que llegó hasta Napoleón, el Judicial nunca fue tratado como un verdadero poder, la acción de juzgar estaba circunscrita a la aplicación mecánica de la ley en una controversia, la función jurisdiccional era una función subordinada a la legislativa, por tanto, el órgano judicial estaba subordinado al Poder Legislativo y, por lo mismo, no podía oponérsele, ni servir de mediador, de freno o de equilibrio. ${ }^{273}$

Una consecuencia de esa concepción dejó una huella profunda en la cultura jurídica francesa. En efecto, con objeto de hacer frente al absolutismo judicial y frente a la arbitrariedad se declaró en los textos constitucionales, como garantía, que la ley era la expresión de la voluntad general, lo que hizo de los jueces la simple boca que pronunciaba la palabra de la ley, pues, se exigía que las sentencias no fueran jamás sino el texto preciso de la ley, según la célebre fórmula de Montesquieu aquí citada, con lo que se les despojó aún de la potestad de interpretar la ley, por

273 Escuchemos a Montesquieu: "hay en cada Estado tres clases de poderes: la potestad legislativa, la potestad ejecutiva de las cosas que dependen de Derecho de Gentes y la potestad ejecutiva de aquellas que dependen del Derecho Civil... Pero si los tribunales no deben ser fijos, las sentencias deben serlo a tal punto que no sean jamás sino un texto preciso de la ley. Si fueran una opinión particular del juez, se viviría en la sociedad sin saber con precisión los compromisos que se contratan... De las tres potestades de las que hemos hablado, la de juzgar es de alguna manera nula. No restan sino dos... Pero los jueces de la Nación no son como lo hemos dicho, sino la boca que pronuncia las palabras de la ley; seres inanimados que no pueden moderar ni la fuerza, ni el rigor de ésta...". Montesquieu, op. cit., pp. 586-589. 
Este libro forma parte del acervo de la Biblioteca Jurídica Virtual del Instituto de Investigaciones Jurídicas de la UNAM

lo que existieron autores que advirtieron una degradación en la función jurisdiccional que al convertirse en poder, paradójicamente, devino en pura administración. ${ }^{274}$

Valdría la pena también añadir una palabra sobre la relación entre el Poder Judicial y el Ejecutivo. Con la adopción del principio de la división de los poderes, particularmente, el Poder Judicial se separó de la administración con la ley del 22 de diciembre al 8 de enero de 1790, configurándose ésta como un poder exento de control por parte de la justicia. En efecto, la sección III del artículo 7o. de dicha ley disponía que las administraciones de departamento y de distrito no podrían ser obstaculizadas en el ejercicio de sus funciones administrativas por ningún acto del Poder Judicial.

La doctrina clásica - dice Troper a este respecto - se dividió sobre la cuestión de la existencia misma de una pretendida función jurisdiccional. Unos afirmaban que el Estado ejercía tres grandes funciones jurídicas: legislativa, ejecutiva y jurisdiccional. $\mathrm{Al}$ contrario, otros pretendían que era imposible concebir más función que la que consistía en hacer la ley y la que consistía en ejecutarla y que, en consecuencia, la actividad por la cual eran resueltos los litigios no podía ser considerada sino como una parte de la función ejecutiva. El nudo aparente de esta controversia era el régimen jurídico de las decisiones de justicia, el statu quo de los magistrados y también la suerte del contencioso administrativo. Admitir que no había sino dos funciones conducía con tales premisas a afirmar que el principio de la especialización de los órganos era perfectamente compatible con la supervisión del jefe del Poder Ejecutivo sobre la función jurisdiccional o con el ejercicio directo de una parte de esta función por la administración. Admitir tres funciones era al contrario, rehusar, en nombre del principio de la especialización, toda competencia jurisdiccional al Poder Ejecutivo. ${ }^{275}$

${ }^{274}$ Cfr. Tomás y Valiente, Francisco, "De la administración de justicia al Poder Judicial", en Obras Completas, Centro de Estudios Políticos y Constitucionales, 1997, t.V, pp. 4169-4182.

275 Troper, Michel, La séparation des pouvoirs..., cit., pp. 43 y 44. 
Este libro forma parte del acervo de la Biblioteca Jurídica Virtual del Instituto de Investigaciones Jurídicas de la UNAM

\section{DATOS BIOGRÁFICOS}

BAILLY, JEAN-SYLVAIN, nació en 1736 y murió ejecutado en la plaza del Campo Marte en 1793; miembro de la Academia Francesa y discípulo de Franklin; diputado de los Estados Generales, constituyente; como alcalde de París renuncia después de "la fusilata del Campo Marte" en 1791; partidario de la reforma limitada a la monarquía. ${ }^{276}$

BARnAVE, ANTOINE-PIERRE-MARIE, nació en Grenoble en 1761 y falleció en 1793; descendiente de familia de notables protestantes, cultos; abogado e hijo de abogado; diputado del Tercer Estado a los Estados Generales, constituyente, brillante orador; junto con Lameth y Du Port formará un triunvirato en el partido patriota y en el club de los jacobinos; poco después cambiará de orientación política, abandona los jacobinos y se adhiere al grupo moderado de los feuillantes y deviene aliado del rey, enjuiciado por el tribunal revolucionario, muere guillotinado. ${ }^{277}$

CaZAlès, Jacques-ANTOINE-MARIE, nació en Haute-Garonne, 1758 y murió en 1805; perteneciente a una familia de la pequeña nobleza; sospechoso para la nobleza, no es bien aceptado; no obstante, es electo por ese orden a los Estados Generales; hostil a la reunión de los órdenes y favorable a las prerrogativas reales, pasará lo esencial de sus últimos años en el exilio.278

276 Gallo, Max, L'homme Robespierre, histoire d'une solitude, París, Libraire Academique Perrin, 1968, p. 317.

277 Furet, François y Halévi, Ran (comps.), Orateurs de la Revolution Française, París, Gallimard, 1989, colección Biblioteca de las Pléyades, t. I: Les Constituants, pp. 1183 y ss.

278 Ibidem, p. 1420. 
Este libro forma parte del acervo de la Biblioteca Jurídica Virtual del Instituto de Investigaciones Jurídicas de la UNAM

Clermont-TONNERRE, STANISLAS-MARIE-AdELAÏDE, nació en Lorena, 1759 y murió en 1792; hombre gentil liberal con corta carrera militar; diputado por la nobleza a los Estados Generales, constituyente; favorable a la verificación de poderes en común; presidente de la Asamblea; miembro de la comisión redactora de la Constitución; monárquico sostiene el veto absoluto y rechaza la expropiación de los bienes del clero; publica una dura censura contra la Constitución; encausado es librado a la furia popular y muere defenestrado. ${ }^{279}$

CRÉNIÈRE, JEAN-BAPTISTE, nació en Vendôme en 1744; traficante en fierro, diputado del Tercer Estado a los Estados Generales, constituyente; se pronuncia contra el veto del Rey; electo al Consejo de Ancianos en el año IV, donde permanece hasta el año VIII. ${ }^{280}$

Vignerod du Plesis de RichelieU, ARMAND-Desiré, DUQUe D’Aiguillon, nació en París, 1761 y murió en 1800, uno de los más ricos propietarios del reino, coronel del regimiento real, diputado de la nobleza a los Estados Generales; constituyente; favorable a la reunión de los tres órdenes, secretario de la Asamblea; acusado, emigra a Londres y después a Hamburgo donde muere. ${ }^{281}$

De Launay Emmanuel-Louis-Henri, Conde D'Antraigues, nació en Montpellier, 1753 y murió asesinado cerca de Londres, en 1812; diputado de la nobleza a los Estados Generales, constituyente; contradictorio en sus principios: defiende la separación de los órdenes y el voto por orden, partidario de una declaración de derechos; defensor de la sanción real, pero partidario del monocamarismo se convierte en agente secreto de las cortes de Rusia y Austria. ${ }^{282}$

\footnotetext{
279 Ibidem, p. 1256.

280 Faure, Christine, op. cit., p. 415.

281 Cfr. Furet François y Halévi, Ran (comps.), Orateurs..., cit., p. 1173.

282 Faure, Christine, op. cit., pp. 433 y 434.
} 
Este libro forma parte del acervo de la Biblioteca Jurídica Virtual del Instituto de Investigaciones Jurídicas de la UNAM

Duport, Adrien-JeAn-Francois, nació en París en 1759 y falleció en 1798; abogado, consejero del Parlamento de París; francmason; diputado de la nobleza a los Estados Generales, constituyente; se separa de la nobleza y forma un triunvirato con Lameth y Barnave; rechaza el bicamarismo y el veto suspensivo; se declara a favor de los judíos y protestantes; niega la propiedad de los bienes eclesiásticos; después de Varennes, defiende al rey y abandona a "los jacobinos"; emigra a Suiza y regresa para volver a emigrar. ${ }^{283}$

Gregoire, Henri-BAPTiSTe, nació en Meurthe-et-Moselle en 1750 y murió en 1831; diputado del clero a los Estados Generales, por la circunscripción de Nancy; primer eclesiástico en prestar juramento constitucional; constituyente; sostiene el voto por cabeza y la reunión del clero con el Tercer Estado; participa en la redacción de la Constitución civil del clero; se pronuncia contra el veto real; votó por la abolición de la monarquía, pero contra la aplicación de la pena de muerte del rey. ${ }^{284}$

Lally-TOlLendal, Tropime-GÉRARD DE, nació en París en 1751 y murió en 1830. Un juicio célebre que conduce a su padre al cadalso le marcará de por vida y lo ligará a la política, dedicando sus afanes a rehabilitar el nombre de su padre, lo que finalmente logra; electo por la nobleza a los Estados Generales; defensor de la monarquía regenerada por reformas, está en favor de la prerrogativa real, constituyente; miembro de la comisión redactora, sostiene el veto ilimitado y la existencia de dos cámaras; acusado y arrestado logra huir a Londres; vuelve a Francia bajo el Consulado; sin embargo, se mantiene al margen hasta la Restauración, actuando en la cámara alta. ${ }^{285}$

MOTIER, MARIE-JOSEPH-PAUL-ROCH-YVES-GILBERT, MARQUÉS DE LA FAYETTE, nació en Chavigniac en 1757 y murió en 1834; afiliado a la francmasonería; parte a la guerra de los Estados Uni-

283 Ibidem, p. 444.

284 Ibidem, p. 439.

285 Cfr. Furet François y Halévi, Ran (comps.), Orateurs..., cit., pp. 1311 y ss. 
Este libro forma parte del acervo de la Biblioteca Jurídica Virtual del Instituto de Investigaciones Jurídicas de la UNAM

dos, es nombrado por Washington, general-mayor de la armada, a su regreso a Francia lucha por los derechos de las minorías; diputado de la nobleza por Riom; constituyente, autor de uno de los proyectos de declaración de derechos; vicepresidente de la Asamblea; comandante de la guardia nacional; no está probada su responsabilidad de "la fusilata del Campo Marte"; se opone al imperio, a Luis XVIII, a Luis Felipe y a Carlos X. ${ }^{286}$

Legrand DE Boislandry, Francois-Louis, nació en París en 1750 y murió en 1834; negociante en Versalles, diputado del Tercer Estado y del vizcondado de París a los Estados Generales, constituyente; propone diversos artículos de la declaración de derechos, sostiene la necesidad de la instrucción pública. ${ }^{287}$

Malouet, Pierre-VÍctor, nació en Riom en 1740 y falleció en 1814; abogado, comisario en Santo Domingo, diputado a los Estados Generales, constituyente, partidario de la reunión de los órdenes, se opone a la declaración de derechos, partidario del veto real y del bicamarismo; monarquista intransigente; forma parte del consejo del rey. ${ }^{288}$

RiQueti, Honoré-Gabriel, GONDE DE MirabeaU, nació en 1749 y murió en 1791; como militar participa en la campaña de Córcega, de vida desordenada es encarcelado y perseguido por la justicia en varias ocasiones; su ruptura familiar le deja sin recursos y vive de sus escritos libertinos; rechazado por la nobleza, es diputado por el Tercer Estado a los Estados Generales, constituyente; orador brillante; miembro de la comisión redactora de la declaración de derechos; partidario del veto real; presidente de la Asamblea dos meses antes de su muerte. ${ }^{289}$

286 Faure, Christine, op. cit., p. 396.

287 Ibidem, p. 469.

288 Ibidem, p. 427.

289 Ibidem, p. 459. 
Este libro forma parte del acervo de la Biblioteca Jurídica Virtual del Instituto de Investigaciones Jurídicas de la UNAM

MOUNIER, JEAN-JOSEPH, nació en Grenoble en 1758 y falleció en 1806; juez real y abogado del Parlamento de Grenoble; diputado del Tercer Estado del Dauphiné a los Estados Generales; constituyente; partidario del veto real y del bicamarismo; presidente de la Asamblea, renuncia el 8 de octubre de 1789; se retira a Suiza y no regresa sino hasta después del 18 Brumario, año VIII. ${ }^{290}$

PisOn du Galand, Alexis-Francois, nació en Grenoble en 1747 y falleció en 1826; abogado, juez episcopal; diputado del Tercer Estado a los Estados Generales, constituyente; propone un comité para la liquidación de los derechos feudales; diputado bajo el Directorio; secretario y presidente del Consejo de los Quinientos; consejero de la corte imperial en 1811; consejero de la corte real en $1816 .{ }^{291}$

RABAUT, SAINT-ÉTIENNE, nació en Nîmes, 1743 y murió guillotinado el 15 Frimario, año II (5 dic de 1793) en París; pastor protestante y abogado, suscita el edicto que concede el estado civil a los protestantes; diputado del Tercer Estado a los Estados Generales, constituyente; miembro del primer comité redactor de la Constitución, se pronuncia por la cámara única y el veto suspensivo; declara la incompetencia de la Asamblea para juzgar al rey, pero vota por la declaración de culpabilidad y solicita el perdón. ${ }^{292}$

SieyÈs, EMmanuel JOSEPH, Nació en Frejus en 1748 y falleció en 1836; canónigo y vicario de Chartres; diputado del clero a la Asamblea Provincial de l'Orleanais; diputado del Tercer Estado a los Estados Generales, constituyente, secretario de la Asamblea; diputado a la Convención, vota la muerte del rey; presidente del Directorio; participa en el golpe de estado del 18 Brumario y es nombrado cónsul junto con Bonaparte y Ducos. ${ }^{293}$

290 Ibidem, p. 409.

291 Ibidem, p. 455.

292 Ibidem, p. 466.

293 Ibidem, pp. 401 y 402. 
Este libro forma parte del acervo de la Biblioteca Jurídica Virtual del Instituto de Investigaciones Jurídicas de la UNAM

Talleyrand-Perigord, Gharles-Maurice, nació en París en 1754 y murió en 1838; de familia noble, es orientado al sacerdocio por una limitación física, vicario general de la diócesis de Reims; obispo de Autun, diputado a los Estados Generales, constituyente; propone la disposición de los bienes del clero por la nación; celebra la misa de la Fiesta de la Federación del 14 de julio de 1790; obispo constitucional; oportunista que sabe sobrevivir a todos los terremotos políticos, y accede a todos los honores y puestos con todos los regímenes políticos. ${ }^{294}$

TARget, Guy-JeAn-BAPTiSTe, nació en París en 1733 y murió en 1806; abogado del Parlamento de París; miembro de la Academia Francesa; diputado por el Tercer Estado a los Estados Generales, constituyente; secretario y después presidente de la Asamblea; partidario del veto suspensivo; solicitado por Luis XVI para defenderlo, se rehúsa; acusado de moderación, se aleja; juez de casación en 1797.295

Tronchet, Francois-Denis, nació en París en 1726 y murió en 1806; abogado del Parlamento de París, diputado del Tercer Estado a los Estados Generales, protesta contra su conversión en Asamblea Nacional; constituyente, aprueba con reservas los acuerdos de la noche del 4 de agosto de 1789; partidario del bicamarismo y del veto absoluto; defensor, junto con Malesherbes y Deveze, de Luis XVI en su proceso; electo al Consejo de Ancianos; juez de casación; miembro del Senado conservador y después presidente del mismo. ${ }^{296}$

294 Cfr. Furet François y Halévi, Ran (comps.), Orateurs..., cit., pp.1549-1551.

295 Faure, Christine, op. cit., p. 412.

296 Ibidem, p. 465. 
Este libro forma parte del acervo de la Biblioteca Jurídica Virtual del Instituto de Investigaciones Jurídicas de la UNAM

\section{BIBLIOGRAFÍA}

ADAms, John, Écrits Politiques et Philosophiques, Caen Presses Universitaires de Caen, vols. I y II, 2004.

BACOT, Guillaume, Carré de Malberg et l'origine de la distinction souveranité du peuple-souveranité nationale, París, Ed. CNRS, 1985.

BACZKO, Bronislaw, "Le contrat social des françaises: Sieyès et Rousseau", "Le contrat social des françaises: Sieyès et Rousseau", The French Revolution and the Creation of Modern Political Culture, Oxford, Pergamon Press, 1987, vol. I: The Political Culture of the Old Regime, editado por Baker, K. M.

BASTID, Paul, Sieyès et sa pensé, París, Hachette, 1970.

, "La place de Sieyès dans l'histoire des institutions", Revue d'Histoire Politique et Constitutionnelle, enero-marzo de 1939.

Bodin, Jean, Les six liures de la République, París, Fayard, 1986.

Botana, Natalio R., "Comentarios finales", en Annino, Antonio (coord.), Historia de las elecciones en Iberoamérica, siglo XIX. De la formación del espacio nacional, Buenos Aires, Fondo de Cultura Económica, 1995.

Boutmy, Emile, "La Déclaration des droits de l'homme et du citoyen et M. Jellinek", Annales des Sciences Politiques, t. XVII, julio de 1902.

BURKE, Edmund, "Reflexiones sobre la Revolución francesa 1790", Textos políticos, México, Fondo de Cultura Economica, 1942.

Burdeau, Georges, Traité de Science Politique, París, LGDJ, t. IV.

CARré De MALberg, Raymond, Contribution á la théorie générale de l'État. Spécialement d'aprés les données fournies par le Droit Constitutionnel français, París, Recueil Sirey, t. II, 1922. 
Este libro forma parte del acervo de la Biblioteca Jurídica Virtual del Instituto de Investigaciones Jurídicas de la UNAM

,"La sanction jurisdictionnelle des principes constitutionnels", Annuaire de l'Institut International de Droit Public, París, 1929. Casirer, Ernst, La Philosphie des Lumières, París, Fayard, 1966.

Castaldo, André, Les Méthodes de travail de la Constituante. Les techniques delibératives de l'Assemblée Nationale 1789-1791, París, PUF, 1989.

Clavreul, Colette, "Sieyès et la genése de la representation moderne", Revue française de théorie juridique, vol. 6, 1987.

_- "Constitution de l'Assamblèe National (17 de junio de 1789)", en Furet, François y Halevi, R., La Monarchie Republicaine, París, Fallard, 1996.

Córdova, Arnaldo, "La concepción jurídico-política de Kant", "De Grocio a Kant. Génesis del concepto moderno de propiedad", Sociedad y Estado en el mundo moderno, México, Grijalbo, 1976.

CRÉNIÈRE, Jean-Baptiste, "Sur la nécessité de précéder la constitution d'une Declaration de Droits de l'Homme (1 de agosto de 1789)", en Furet, François y Halévi, Ran, La Monarchie Republicaine, París, Fallard, 1996.

Gueva, Mario de la, Apuntes para el curso de derecho constitucional, México, Mimeo, 1964.

-, Teoría de la Constitución, México, Porrúa, 1982.

Chaussinand-Nogaret, Guy, Mirabeau entre le roy et la Revolution, París, Hachette, 1986.

ChevalLier, Jean-Jacques, Histoire des institutions et des régimes politiques de la France de 1789 á nos jours, París, Dalloz, 1972.

D’Aiguillon, "Discours du Duque d'Aiguillon. Motion sur les privilèges particuliers et sur les droits féudaux et seigneuriaux", en Furet, François y HaLÉvi, Ran (comps.), Orateurs de la Revolution Française, París, Gallimard, 1989, colección Biblioteca de las Pléyades, t. I: Les Constituants.

— , 'D' Antraigues. Discours du comte D'Antraigues á la chambre de la nobless sur le caractère constitutif de la division 
Este libro forma parte del acervo de la Biblioteca Jurídica Virtual del Instituto de Investigaciones Jurídicas de la UNAM

des ordres (28 de mayo de 1789)", en FURET, François y HALÉVI, Ran, La Monarchie Republicaine, París, Fallard, 1996.

1789)", en FURET, François y HALÉvi, Ran, La Monarchie Republicaine, París, Fallard, 1996.

, "Declaration des Droits de l'Homme et du Citoyen (26 de agosto de 1789)", Les Declarations de Droits de l'Homme de 1789 , París, Payot, 1992.

, "Décret relatif á la abolition des privileges (11 de agosto de 1789)", en FURET, François y HALÉVI, Ran, La Monarchie Republicaine, París, Fallard, 1996.

, "Discours du Roi á la ouverture des États Généraux (5 de mayo de 1789)", en Furet, F. y HALÉvi, R., La Monarchie Republicaine, París, Fallard, 1996.

Duguit, Leon, Traité de Droit Constitutionnel, París, Ancienne Librairie Fontemoing, t. II, 1921.

- La separación de poderes y la Asamblea Nacional de 1789, Madrid, Centro de estudios constitucionales, 1996.

Eisenmann, Charles, "El espíritu de las leyes y la separación de poderes", Anuario furídico, México, núm. 2, 1975.

Ellul, Jacques, Histoire des Institutions, París, PUF, vol. 5, 1969.

FAuré, Christine, "Presentation", Les Declarations de Droits de l'Homme de 1789, París, Payot, 1992.

Ferrero, Guglielmo, Les Deux Revolutions Françaises, Boudry, Ed. de la Baconnière, 1951.

FIORAVANTI, Maurizio, Los derechos fundamentales. Apuntes de historia de las Constituciones, Madrid, Trotta, 2003.

, "Estado y Constitución”, en Fioravanti, Maurizio (ed.), El Estado moderno en Europa. Instituciones y derecho, Madrid, Trotta, 2002.

Furet, François y HALÉvi, Ran, La Monarchie Republicaine, París, Fallard, 1996. 
Este libro forma parte del acervo de la Biblioteca Jurídica Virtual del Instituto de Investigaciones Jurídicas de la UNAM

-, Orateurs de la Revolution Française, París, Gallimard, 1989, colección Biblioteca de las Pléyades, t. I: Les Constituants.

, y Richet, Denis, La Revolution Française, París, Hachette, 1973, colección Pluriel.

GODEGHOT, Jacques, Les institutions de la France sous la Revolution et L'Empire, París, PUF, 1951. rís, Garnier-Flammarion, 1970.

GrEGOIRE, Henri-Baptiste, "Sur la nécessité de parler des devoirs dans la Declaration des Droits de l'Homme et du citoyen (sesión del 12 de agosto de 1789, pero ciertamente pronunciado el 4 del mismo mes)", Les Declarations de Droits de l'Homme de 1789, París, Payot, 1992.

Habermas, Jürgen, Derecho natural y Revolución, Buenos Aires, Ed. Sur, 1966.

Hamilton, Madison y Jay, El Federalista, México, Fondo de Cultura Económica, 1957.

Hauriou, André, Droit constitutionnel et institutions politiques, París, Ed. Montchrestien, 1968.

JellineK, Georg, L'État moderne et son Droit, París, Ed. Giard et Briére, vol. II, 1913.

Jouffroy, Theodoré, Cours de droit naturel, París, Fayard, 1988.

LALLY-TOLLENDAL, "Discours de Lally-Tollendal sur l'organisation du Pouvoir Législatif et la sanction royale (31 de agosto de 1789)", en Furet, François y HaLévi, Ran, La Monarchie Republicaine, París, Fallard, 1996.

LefeBre, Geoges, La Revolution Française, París, PUF, 1963.

LOCKE, John, Essai sur le pouvoir civil, París, PUF, 1953.

MACPHERSON, Crawford Brough, La théorie politique de l'individualisme possesif. De Hobbes á Locke, París, Gallimard, 1971.

MAIstre, Joseph de, Écrits sur la Révolution, París, PUF, 1989. 
Este libro forma parte del acervo de la Biblioteca Jurídica Virtual del Instituto de Investigaciones Jurídicas de la UNAM

Malouet, "Discours de Malouet sur la sanction royale (1 de septiembre de 1789)", en Furet, François y HaLÉvi, Ran, La Monarchie Republicaine, París, Fallard, 1996.

-, "Sur les dangers d'une declaration des droits de l'homme (1 de agosto de 1789)", en Furet, François y HaLÉVI, Ran, La Monarchie Republicaine, París, Fallard, 1996.

Mirabeau, "Troisième lettre du Comte de Mirabeau á ses commetants", en FURET, François y HALÉVI, Ran, La Monarchie Republicaine, París, Fallard, 1996.

, "Quatrième lettre du Comte de Mirabeau á ses commetants", en FurEt, François y HALÉVI, Ran, La Monarchie Republicaine, París, Fallard, 1996.

, "Premier discours de Mirabeau sur la denomination de l'Assamblee (15 de junio de 1789)", en FuRET, François y HALÉVI, Ran, La Monarchie Republicaine, París, Fallard, 1996.

, "Discours sur la suppresion ou le rachat des dîmes (10 de agosto de 1789)", en FURET, François y HALÉvi, Ran (comps.), Orateurs de la Revolution Française, París, Gallimard, 1989, colección Biblioteca de las Pléyades, t. I: Les Constituants.

(17 de agosto de 1789)", en FuRET, François y HaLÉvi, Ran (comps.), Orateurs de la Revolution Française, París, Gallimard, 1989, colección Biblioteca de las Pléyades, t. I: Les Constituants.

"Second discours sur la Declaration des Droits de l'Homme (18 de agosto de 1789)", en FurET, François y HALÉVI, Ran (comps.), Orateurs de la Revolution Française, París, Gallimard, 1989, colección Biblioteca de las Pléyades, t. I: Les Constituants,

"Discours de Mirabeau sur le droit de veto (1 de septiembre de 1789)", en FuRET, François y HaLÉvi, Ran, La Monarchie Republicaine, París, Fallard, 1996.

-, "Sur l'exercise du droit de guerre et de paix (20-22 mayo de 1790)", en Chaussinand-NoGaret, Guy, Mirabeau entre le roy et la Revolution, París, Hachette, 1986. 
Este libro forma parte del acervo de la Biblioteca Jurídica Virtual del Instituto de Investigaciones Jurídicas de la UNAM

(7 de noviembre de 1789)", en Chaussinand-Nogaret, Guy, Mirabeau entre le roy et la Revolution, París, Hachette, 1986.

Montesquieu, 'L'Esprit des Lois et la querelle de l'Esprit des Lois. 1748-1750", en Oeuvres complètes, París, Ed. du Seuil, 1964.

MOUnIER, "Discurso de Mounier sobre la sanción real (5 de septiembre de 1789)", en Furet, François y HaLÉVI, Ran, La Monarchie Republicaine, París, Fallard, 1996.

-, "Rapport du Comité chargé du travail sur la Constitution (9 de julio de 1789)", en FurET, François y HaLÉvi, Ran (comps.), Orateurs de la Revolution Française, París, Gallimard, 1989, colección Biblioteca de las Pléyades, t. I: Les Constituants, 1989.

PAsquino, Pascuale, "Emmanuel Sieyès, Benjamin Constant et le Gouvernement des modernes. Contribution á l'Histoire du concept de representation politique", Revue Française de Science Politique, abril de 1987.

— Sieyès et l'invention de la constitution en France, París, Ed. Odile Jacob, 1998.

PÉREz TREMPS, Pablo, "Presentación”, en Duguit, La separación de los poderes y la Asamblea Nacional de 1789, Madrid, Centro de estudios constitucionales, 1996.

PÉTIOn, Jérôme, "Sur le gouvernement représentatif et le droit de veto (5 de septiembre de 1789)", en FurET, François y HaLÉvi, Ran, La Monarchie Republicaine, París, Fallard, 1996.

PIRENNE, Jacques, Historia universal, Barcelona, Ed. Éxito, vol. V, 1973.

PosadA, Adolfo, "Estudio preliminar", en Jellinek, J., La Declaración de los Derechos del Hombre y del Ciudadano, Madrid, Librería General de Victoriano Suárez, 1908.

, "Projet de Declaration des Droits de l'Homme en societé (17 de agosto de 1789)", Les Declarations de Droits de l'Homme de 1789, París, Payot, 1992. 
Este libro forma parte del acervo de la Biblioteca Jurídica Virtual del Instituto de Investigaciones Jurídicas de la UNAM

RicHET, Denis, "L'esprit de la constitution, 1789-1791", The French Revolution and the Creation of Modern Political Culture, Oxford, Pergamon Press, 1988, vol. II: The political culture of the French revolution (Ed. Colin Lucas).

Rosanvallon, Pierre, "Les doctrinaires et la question du gouvernement representative", The French Revolution and the creation of modern political culture, Oxford, Pergamon Press, 1989, vol. III: The transformation of political culture, editado por Furet-Ozouf, 1989.

- La consagración del ciudadano. Historia del sufragio universal en Francia, México, Instituto Mora, 1999.

Rousseau, Jean Jacques, Du contrat social, Ginebra, Les editions du cheval ailé, 1947.

SIEYÈs, Emmanuel Joseph, "Consideraciones sobre los medios de ejecución de los cuales los representantes de Francia podrán disponer en 1789", en PANTOJA MORÁn, David (comp.), Escritos políticos de Sieyès, México, Fondo de Cultura Económica, 1993.

, "Ensayo sobre los privilegios", en PANTOJA Morán, David (comp.), Escritos políticos de Sieyès, México, Fondo de Cultura Económica, 1993.

, “Qué es el Tercer Estado?”, en Pantoja Morán, David (comp.), Escritos políticos de Sieyès, México, Fondo de Cultura Económica, 1993.

"Motion sur la verification des pouvoirs (10 de junio de 1789)", en FurET, François y HALÉvi, Ran (comps.), Orateurs de la Revolution Française, París, Gallimard, 1989, colección Biblioteca de las Pléyades, t. I: Les Constituants.

, "Opinión del señor abate Sieyès sobre el decreto del 4 relativo a los diezmos, pronunciada el 10 de agosto en la sesión vespertina", en PANTOJA MORÁn, David (comp.), Escritos politicos de Sieyès, México, Fondo de Cultura Económica, 1993.

, "Breves observaciones sobre los bienes eclesiásticos", en Pantoja Morán, David (comp.), Escritos políticos de Sieyès, México, Fondo de Cultura Económica, 1993. 
Este libro forma parte del acervo de la Biblioteca Jurídica Virtual del Instituto de Investigaciones Jurídicas de la UNAM

posición razonada de los Derechos del Hombre y del Ciudadano", en Pantoja Morán, David (comp.), Escritos políticos de Sieyès, México, Fondo de Cultura Económica, 1993.

, Opinión de Sieyès sobre varios artículos de los títulos IVy V del proyecto de Constitución, en PANTOJA MORÁn, David (comp.), Escritos políticos de Sieyès, México, Fondo de Cultura Económica, 1993.

, "Palabras del abate Sieyès sobre la cuestión del veto real", en Pantoja Morán, David (comp.), Escritos políticos de Sieyès, México, Fondo de Cultura Económica, 1993.

, "El veto. Intervención de Sieyês (7 de septiembre de 1789)", Les grands discours parlamentaires de la Revolution. De Mirabeau á Robespierre. 1789-1795, París, Armand Colin, 2005.

ción acerca de la nueva organización de Francia", en PANTOJA Morán, David (comp.), Escritos políticos de Sieyès, México, Fondo de Cultura Económica, 1993.

Soboul, Albert, Histoire de la Revolution Française, París, Idèes, Gallimard, 1970.

Strauss, Leo, Droit naturel et Histoire, París, Flammarion, 1986.

Talmon, Jacob Leib, Les origines de la démocratie totalitaire, París, Calman-Levy, 1966.

Tena Ramírez, Felipe, Derecho constitucional mexicano, México, Porrúa, 2000.

Thouret, "Discurso de 24 de marzo de 1790", en Furet, François y HaLÉvi, Ran, La Monarchie Republicaine, París, Fallard, 1996.

Tocqueville, Alexis de, El antiguo régimen y la Revolución, México, Fondo de Cultura Económica, 1996.

TOMÁs Y VAliENTE, Francisco, "De la administración de justicia al Poder Judicial", Obras Completas, Centro de Estudios Políticos y Constitucionales, t. V, 1997.

TROPER, Michel, La separation des pouvoirs et l'histoire constitutionnelle française, París, L.G.D.J., 1980. 
Este libro forma parte del acervo de la Biblioteca Jurídica Virtual del Instituto de Investigaciones Jurídicas de la UNAM

"La souveranité nacionale appartient au peuple. L'article 3 de la constitution de 1958", en TROPER, Michel y JAUME, Lucien (dirs.), 1789 et l'invention de la constitution, LGDJ- Bruylant, 1994.

, Pour une théorie juridique de l'État, París, PUF-Leviathan, 1994. droit constitutionnel, núm. 9, 1992.

y JAUME, Lucien, "Avant-propos. Une nouveauté toujours actuelle, le texte de 1791", en TrOPER, Michel y JAuMe, Lucien (dirs.), 1789 et l'invention de la constitution, LGDJ- Bruylant, 1994.

Tulard, Fayard, Fierro, Histoire et dictionnaire de la Revolution francaise. 1789-1799, París, Laffont, 1998.

VERPEAUX, Michel, “1791, première constitution française?”, Revue francaise de droit constitutionnel, núm. 13, 1993.

ZAPPERI, Roberto, "Sieyès et l'abolition de la féodalité", Annales historiques de la Revolution Française, núm. 44, 1972. 
Este libro forma parte del acervo de la Biblioteca Jurídica Virtual del Instituto de Investigaciones Jurídicas de la UNAM

\section{ACERGA DEL AUTOR}

Doctor en Ciencias Sociales por El Colegio de Michoacán, A. C.; realizó estudios en la Facultad de Derecho y en el Instituto de Estudios Políticos, ambos de la Universidad de París. Actualmente es profesor titular C de tiempo completo en la Facultad de Ciencias Políticas y Sociales de la UNAM; investigador nacional nivel II.

Autor de libros y artículos sobre ciencia política, derecho constitucional e historia constitucional, como: El Supremo Poder Conservador. El diseño institucional en las primeras Constituciones mexicanas y Bases del constitucionalismo mexicano. La Constitución de 1824 y la teoría constitucional; editor y compilador de Escritos políticos de Sieyès. 
La Asamblea Nacional Francesa de 1789-1791 y la invención de la Constitución, editado por el Instituto de Investigaciones Jurídicas de la UNAM, se terminó de imprimir el 7 de abril de 2017 en los talleres de Arte Gráfico y Sonoro, Agys Alevin, S. C., Retorno de Amores 14102, colonia Del Valle, delegación Benito Juárez, 03100 Ciudad de México, tel. 5523 1151. Se utilizó tipo Baskerville en 9, 10 y 11 puntos. En esta edición se empleó papel book cream de 60 gramos para los interiores y cartulina couché de 250 gramos para los forros. Consta de 200 ejemplares (impresión digital). 